DOE/EIA-0206(94)

February 1996

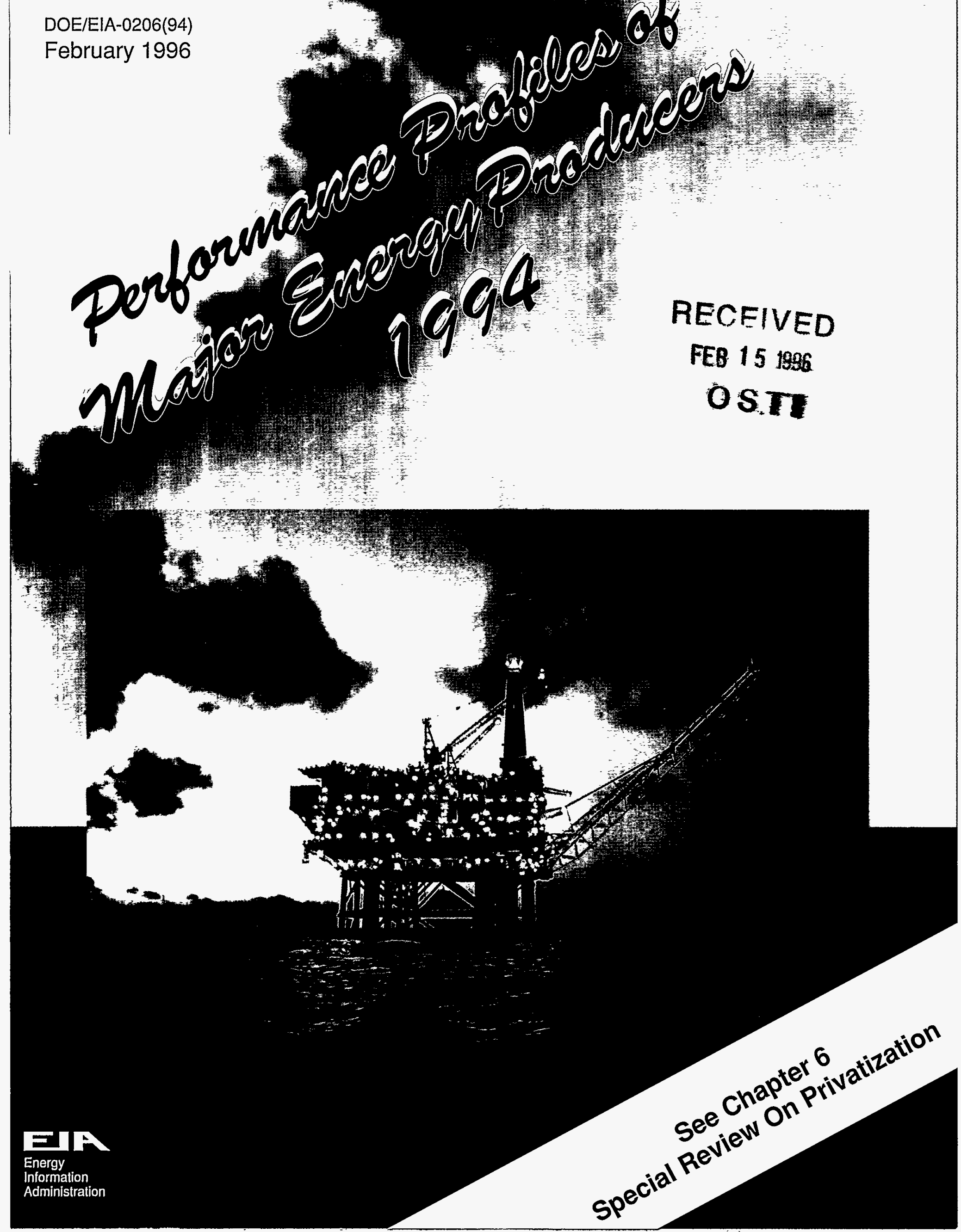


This publication and other Energy Information Administration (EIA) publications may be purchased from the Superintendent of Documents, U.S. Government Printing Office.

\section{Telephone orders may be directed to:}

Superintendent of Documents

U.S. Government Printing Office

Main Order Desk

(202) $512-1800$

FAX: (202) 512-2250

8 a.m. to $4: 30$ p.m., eastern time, M-F

\section{All mail orders should be directed to:}

U.S. Government Printing Office

P.O. Box 371954

Pittsburgh, PA 15250-7954

Complimentary subscriptions and single issues are available to certain groups of subscribers, such as public and academic libraries, Federal, State, local and foreign governments, EIA survey respondents, and the media. For further information and for answers to questions on energy statistics, please contact EIA's National Energy Information Center. Address, telephone numbers, and hours are as follows:

National Energy Information Center, EI-231

Energy Information Administration

Forrestal Building, Room 1F-048

Washington, DC 20585

(202) $586-8800$

(202) 586-0727 (FAX)

TTY: For people who are deaf or hard of hearing: (202) 586-1181

9 a.m. to 5 p.m., eastern time, M-F

Internet Addresses:

E-mail: infoctr@eia.doe.gov

World Wide Web Site: http://www.eia.doe.gov

Gopher Site: gopher://gopher.eia.doe.gov

FTP Site: ftp://ftp.eia.doe.gov

\section{Photo Credit for the Cover:}

We would like to thank the Oryx Energy Company for the use of this photograph of a production platform in the North Sea. 
Dear Performance Profiles of Major Energy Producers 1994 Reader:

Your input regarding this report is welcomed. Please take a moment to answer the following questions. Your response will be very valuable in helping the Energy Information Administration provide better customer service and products to you. Thank you for your help.

1. Listed below in Column I are a number of characteristics often associated with high-quality data and analysis products. In Column II, rate this report on how important each characteristic is to you on a scale of 1 (Not at All Important) to 5 (Very Important). In Column III, rate your level of satisfaction for each characteristic as it relates to this report on a scale of 1 (Very Dissatisfied) to 5 (Extremely Satisfied).

\begin{tabular}{||l|l|l||}
\hline \multicolumn{1}{|c|}{$\begin{array}{c}\text { Column I } \\
\text { Publication } \\
\text { Characteristics }\end{array}$} & $\begin{array}{c}\text { Column II } \\
\text { Level of } \\
\text { Importance }\end{array}$ & $\begin{array}{c}\text { Column III } \\
\text { Level of } \\
\text { Satisfaction }\end{array}$ \\
\hline 1. Accessibility & & \\
\hline 2. Timeliness & & \\
\hline 3. Accuracy & & \\
\hline 4. Readability & & \\
\hline 5. Comprehensiveness & & \\
\hline 6. Appendix B Data Tables & & \\
\hline 7. Illustrative Tables and & & \\
Graphics & & \\
\hline 8. Extent/Depth of Analysis & & \\
\hline
\end{tabular}

2. Below is a list of other ways by which EIA distributes this financial data and analyses. Please check those of interest; we will phone you with more information on them.
[ ] PC Diskette
[ ] On-Line Electronic Dissemination
[ ] CD-ROM
[ ] Fax

Please provide your name, address, telephone, and fax numbers in the space below so that we can contact you.

Name:

Address:

Telephone:

Fax:

Internet Address:

When you have completed this survey, please mail, or fax to (202) 586-6618. 


\section{BUSINESS REPLY MAIL}

FIRST-CLASS MAIL PERMIT NO. 19525 WASHINGTON DC

POSTAGE WILL BE PAID BY ADDRESSEE

U. S. DEPARTMENT OF ENERGY

Attn: Greg Filas

EI-622.

1000 Independence Avenue, SW

Washington, DC 20077-5651 
DOE/EIA-0206(94)

Distribution Category UC-950

\title{
Performance Profiles of Major Energy Producers 1994
}

\author{
February 1996
}

\author{
Energy Information Administration \\ Office of Energy Markets and End Use \\ U.S. Department of Energy \\ Washington, DC 20585
}

This report was prepared by the Energy Information Administration, the independent statistical and analytical agency within the Department of Energy. The information contained herein should not be construed as advocating or reflecting any policy position of the Department of Energy or any other organization. 


\section{Contacts}

This report was prepared in the Office of Energy Markets and End Use of the Energy Information Administration, U.S. Department of Energy, under the general direction of $W$. Calvin Kilgore. The project was directed by Mark E. Rodekohr, Director of the Energy Markets and Contingency Information Division (202) 586-1441, and Mary E. Northup, Chief of the Financial Analysis Branch (202) 586-1445.
Specific technical information concerning this report, and the associated data survey (Form EIA-28), may be obtained from Jon A. Rasmussen (202) 586-1449. The following authors contributed to this report: Neal Davis (Chapters 4,.5, and 6), Marie Fagan (Chapter 3), Susanne Johnson (Chapters 4 and 5), Kevin Lillis (Chapters 4 and 6), Jon Rasmussen (Executive Summary, Chapters 1 and 2), and Dennis Sumner (Chapter 2).

\section{Diskette Information}

Historical Financial Reporting System (FRS) data are available on a 3.5- or 5.25-inch high-density diskette. These data cover the years 1977 through 1994, published in the Energy Information Administration's annual editions of Performance Profiles of Major Energy Producers. There are two different sets of data: aggregate data from the FRS survey form and multi-year tables from Appendix B of Performance Profiles of Major Energy Producers.

The Financial Reporting System 1977-1994 diskette is available from the Energy Information Administration. Pleasē contact Gregory P. Filas. Telephone (202) 586-1347, Fax (202) 586-9753, or on INTERNET gfilas@eia.doe.gov.

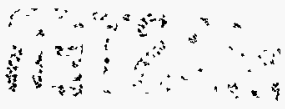




\section{Preface}

The purpose of this publication is to examine developments in the operations of the major U.S. energyproducing companies on a corporate level, by major line of business, by major function within each line of business, and by geographic area.

Pursuant to Section 205(h) of the Department of Energy Organization Act, which established the Financial Reporting System (FRS), the Energy Information Administration (EIA), through its Form EIA-28, collects financial information and other measures of energyrelated business efforts and results for major energy companies. Since the FRS data are collected on a uniform, segmented basis, the comparability of information across energy lines of business is unique to this reporting system. For example, petroleum activities can be compared to activities in other energy lines of business or nonenergy areas, and domestic activities can be compared to foreign activities.

This report presents data collected on Form ELA-28 for the calendar year 1994. In 1994, 24 companies filed
Form EIA-28. The analysis and data presented in this report represent the operations of the FRS companies in the context of their worldwide operations and in the context of the major energy markets which they serve. Both energy and nonenergy developments of these companies are analyzed. Although the focus is on developments in 1994, important trends prior to that time are also featured.

Economic performance, in financial and physical dimensions, continues to serve as a significant factor in evaluating past decisions and guiding future options in the development and supply of energy resources. The information contained in this report is intended to promote an understanding and provide a critical review of the possible motivations and apparent consequences of investment decisions by some of the largest corporations in the energy industry. The information is intended for use by the U.S. Congress, Government agencies, industry analysts, and the general public. 


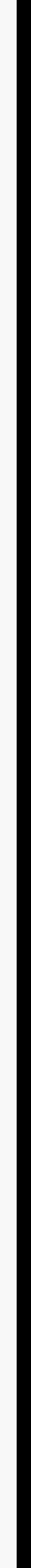




\section{Contents}

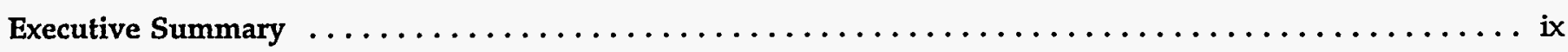

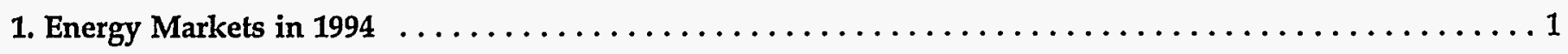

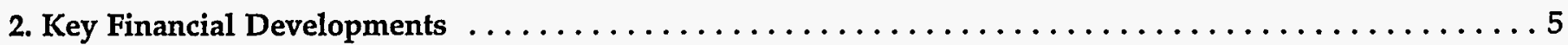

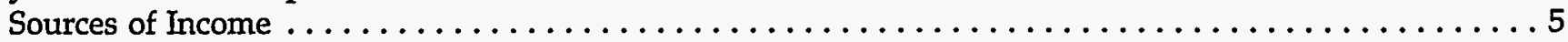

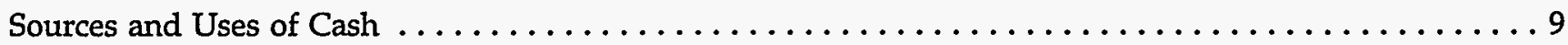

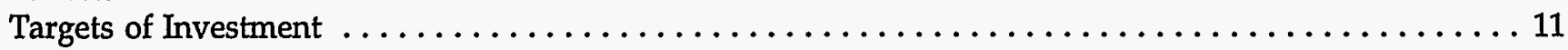

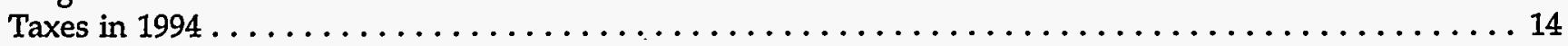

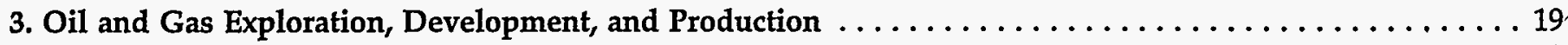

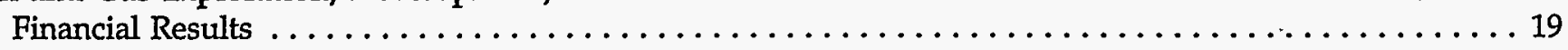

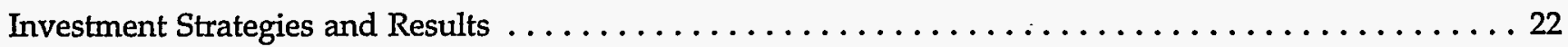

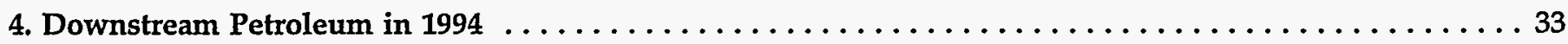

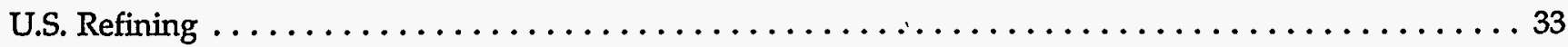

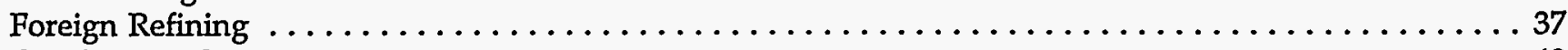

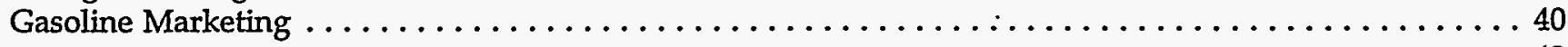

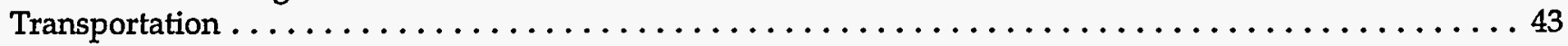

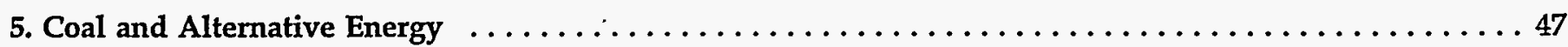

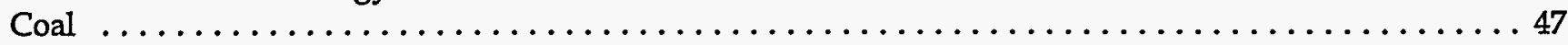

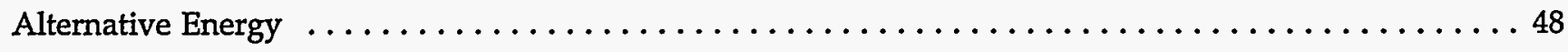

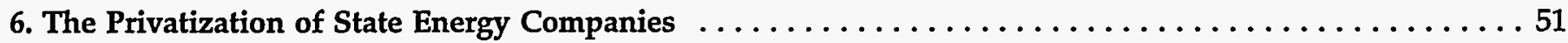

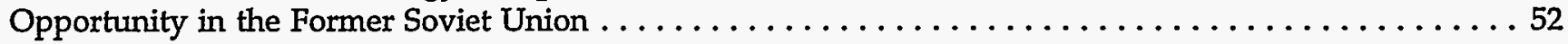

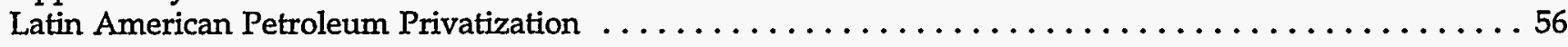

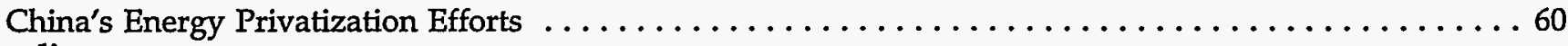

Appendices

A. Structure of the Financial Reporting System - Form EIA-28 $\ldots \ldots \ldots \ldots \ldots \ldots \ldots \ldots \ldots \ldots \ldots$

B. Detailed Statistical Tables . . . . . . . . . . . . . . . . . . . . . . . 77

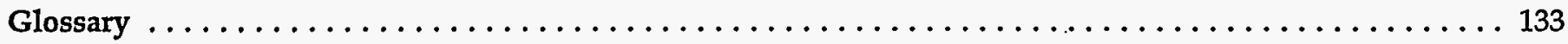




\section{Tables}

1. Consolidated Income Statement for FRS Companies, 1993 and $1994 \ldots \ldots \ldots \ldots \ldots \ldots \ldots$

2. Contributions to Net Income by Line of Business for FRS Companies, $1993-1994 \ldots \ldots \ldots \ldots \ldots \ldots \ldots$. . . . 7

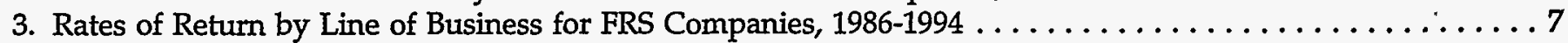

4. Operating Income in Chemicals and Other Nonenergy Segments for FRS Companies, 1993-1994 ․ . . . . 8

5. Line-of-Business Contributions to Pretax Cash Flow for FRS Companies, 1993-1994 . . . . . . . . . . . . 10

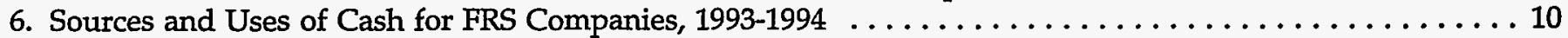

7. Additions to Investment in Place by Line of Business for FRS Companies, 1993-1994 . . . . . . . . . 12

8. Value of Mergers, Acquisitions, and Related Transactions by FRS Companies, 1994 . . . . . . . . . . 13

9. Composition of Income Tax Expense for FRS Companies, 1993-1994 . . . . . . . . . . . . . . . . . 16

10. Income Tax Expense, Pretax Income, and Effective Tax Rates by Line of Business for FRS Companies,

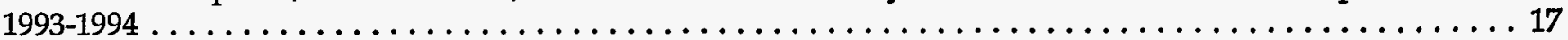

11. Income Components and Financial Ratios in Oil and Gas Production for FRS Companies, 1993-1994 . . . . 20

12. Average Prices, Sales, and Production in Oil and Gas for FRS Companies, 1993-1994 . . . . . . . . . 21

13. Exploration and Development Expenditures for FRS Companies by Region, 1993-1994 . . . . . . . . . 22

14. Well Completions by Region for FRS Companies, $1992-1994 \ldots \ldots \ldots \ldots \ldots \ldots \ldots \ldots \ldots \ldots \ldots \ldots . \ldots \ldots$

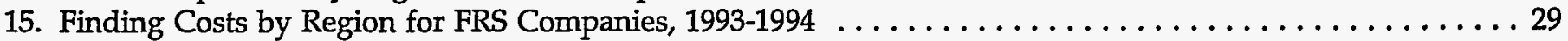

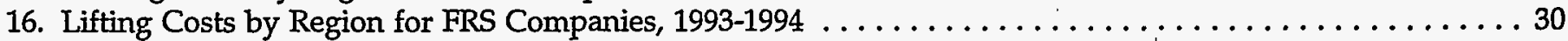

17. Oil and Gas Reserves and Production for FRS Companies, $1993-1994 \ldots \ldots \ldots \ldots \ldots \ldots \ldots \ldots$

18. Sales, Expenses, and Income in U.S. Refining/Marketing for FRS Companies, 1993-1994 . . . . . . . . . . 33

19. FRS U.S. Refined Product Margins and Costs per Barrel Sold, Selected Years, 1977-1994 . . . . . . . . . . . 34

20. Refining/Marketing Financial Items, for FRS Companies, $1993-1994 \ldots \ldots \ldots \ldots \ldots \ldots \ldots$. . . . . . . 34

21. Refining and Marketing Investment and Operating Data for FRS Companies, 1993-1994 . . . . . . . . 36

22. Marketing Characteristics and Refined Product Margin for FRS Companies Ranked by Total Energy Assets,

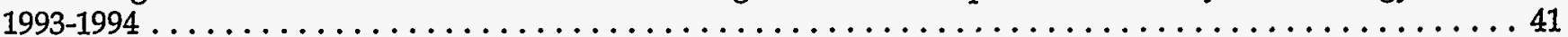

23. Gasoline Distribution by FRS Companies, $1993-1994 \ldots \ldots \ldots \ldots \ldots \ldots \ldots \ldots \ldots \ldots \ldots \ldots \ldots \ldots$

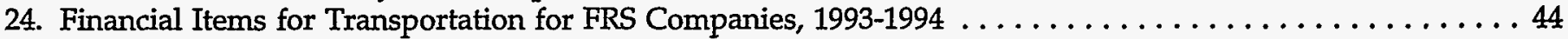

25. Coal Financial and Operating Indicators for the FRS Companies, $1993-1994 \ldots \ldots \ldots \ldots \ldots \ldots \ldots \ldots$

26. Financial and Operating Items for Continuing FRS Coal Producers, $1993-1994 \ldots \ldots \ldots \ldots \ldots \ldots \ldots$

27. Revenues, Income, and Investment in Other Energy for FRS Companies, 1993-1994 . . . . . . . . . . 49

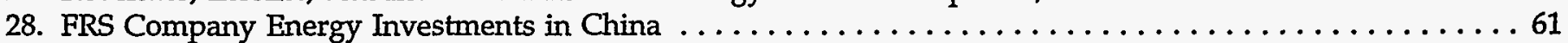

A1. Companies Reporting to the Financial Reporting System, $1977-1994 \ldots \ldots \ldots \ldots \ldots \ldots \ldots \ldots \ldots \ldots$

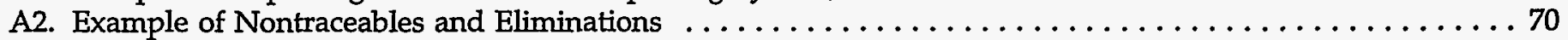

A3. A Comparison Between Full Cost and Successful Efforts Accounting Methods . . . . . . . . . . . 73

A4. The Impact of FASB-52, Foreign Currency Translations, on Stockholders' Equity and Pretax Income,

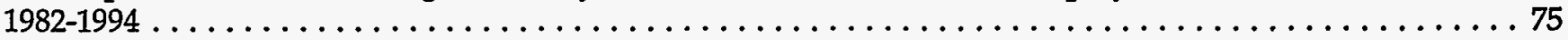

B1. Selected U.S. Operating Statistics for FRS Companies and U.S. Industry, 1993 and $1994 \ldots \ldots \ldots \ldots$. . . . 77

B2. Selected U.S. Operating Statistics for FRS Companies and U.S. Industry, 1988-1994 . . . . . . . . . 78

B3. A Comparison of Selected Financial Items for FRS Companies and the S\&P 400, 1994

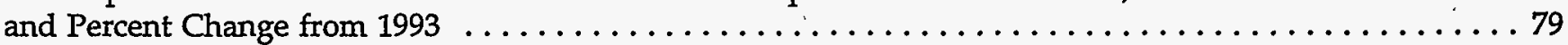

B4. Consolidating Statement of Income for FRS Companies, $1994 \ldots \ldots \ldots \ldots \ldots \ldots \ldots \ldots \ldots \ldots \ldots$

B5. Consolidating Statement of Income for FRS Companies, U.S. and Foreign Petroleum Segments,

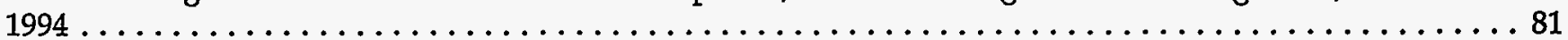

B6. Profit Rates for Lines of Business and Petroleum Segments for FRS Companies, 1988-1994 . . . . . . . 82

B7. Profit Rates for Petroleum Segments for FRS Companies Ranked by Total Energy Assets, $1992-1994$. . . . . . . . . . . . . . . . . . . . . . . . . . . . . . . . 8 83

B8. A Comparison of Balance Sheet Items for FRS Companies and the S\&P 400, 1994 and

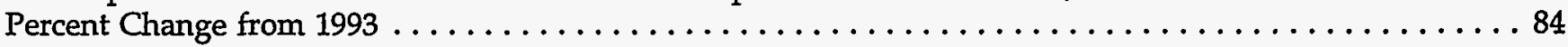

B9. Consolidated Balance Sheet for FRS Companies, $1988-1994 \ldots \ldots \ldots \ldots \ldots \ldots \ldots \ldots \ldots \ldots \ldots \ldots$

B10. Distribution of Net Investment in Place for FRS Companies, United States and Foreign, 1994 . . . . . . . 86

B11. Net Property, Plant and Equipment (PP\&E), Additions to PP\&E, Investments and Advances, and Depreciation, Depletion and Amortization (DD\&A), by Lines of Business for FRS Companies, 1994 . . . . 87 
B12. Income and Investment Patterns in Worldwide Petroleum for FRS Companies Ranked by Total Energy Assets, 1994, and Percent Change from $1993 \ldots \ldots \ldots \ldots \ldots \ldots \ldots \ldots \ldots \ldots$. . . . . . . . . . . . . .

B13. Income and Investment Patterns by Petroleum Segments for FRS Companies Ranked by Total Energy Assets, 1994, and Percent Change from 1993 . . . . . . . . . . . . . . . . . . . . . . . . 89

B14. Size Distribution of Income and Investment Within Worldwide Petroleum for FRS Companies

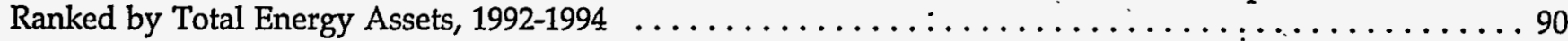

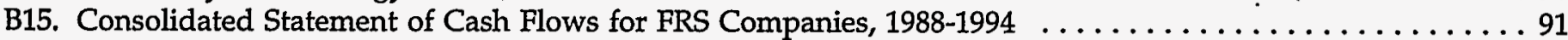

B16. A Comparison of Key Financial Indicators, Selected Performance Measures, and Patterns of

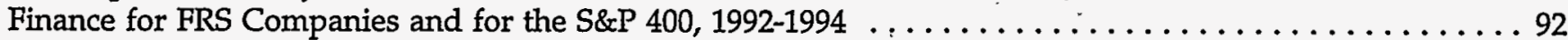

B17. Worldwide Income Taxes for FRS Companies, 1993 and $1994 \ldots \ldots \ldots \ldots \ldots \ldots \ldots \ldots \ldots \ldots$

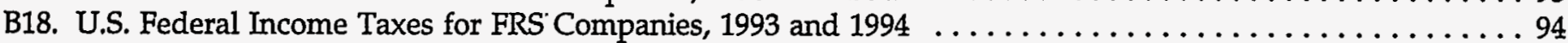

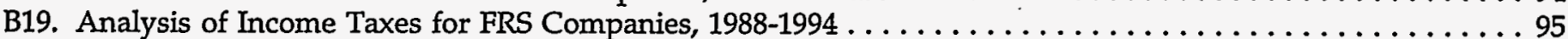

B20. U.S. Taxes Other Than Income Taxes for FRS Companies, 1994,' and Percent Change from 1993 . . . . . . .'96

B21. Petroleum Exploration and Developmerit Expenditures for FRS Companies, United States and

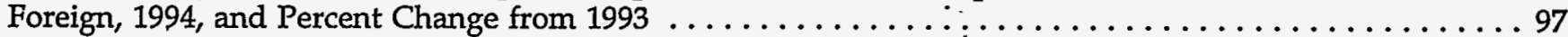

B22. U.S. and Foreign Exploration and Development Expenditures and Production (Lifting) Costs for FRS Companies, $1994 \ldots \ldots \ldots \ldots \ldots \ldots \ldots \ldots \ldots \ldots \ldots \ldots \ldots \ldots \ldots \ldots$

B23. Total Exploratory and Development Wells Drilled in the United States for FRS Companies and

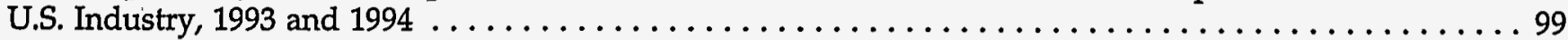

B24. Completed Well Costs, Oil, Gas, and Dry, for FRS Companies and U.S. Industry, 1993 and 1994 . . . . . 100

B25. Completed Well Costs, Oil, Gas, and Dry, Onshore and Offshore, for FRS Companies, 1993 and 1994 . . . . . . . . . . . . . . . . . . . . . . . . . . . . . . . . . . . . . . . 101

B26. U.S. Net Wells Completed, and Net In-Progress Wells for FRS Companies, 1988-1994 . . . . . . . . . . . . 102

B27. Exploration and Development Net Drilling Footage for FRS Companies, 1988-1994 . . . . . . . . . . . 103

B28. U.S. Net Producing Wells and U.S. Acreage for FRS Companies, 1988-1994 . . . . . . . . . . . . . . . . . 104

B29. U.S. Net Petroleum Acreage for FRS Companies, Ranked by Total Energy Assets, 1994,

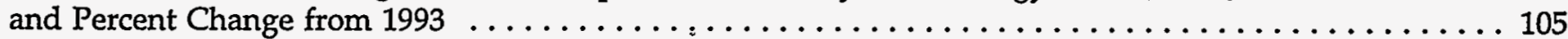

B30. U.S. Net Ownership Interest Petroleum Reserves and Production for FRS Companies and

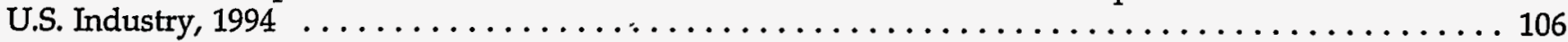

B31. Proved Petroleum Reserves for FRS Companies, United States and Foreign, 1994 . . . . . . . . . . . 107

B32. U.S. Reserve Additions, Exploration and Development Expenditures, and Expenditures per Barrel of Reserve Additions for FRS Companies Ranked by Total Energy Assets and for U.S. Industry,

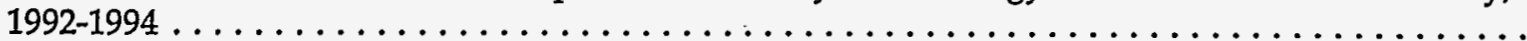

B33. Foreign Petroleum Exploration, Development, Reserves, and Production Statistics by Geographic Area for FRS Companies and Foreign Industry, 1994, and Percent Change from 1993 . . . . . . . . . . . 109

B34. Foreign Exploration and Development Expenditures by Region for FRS Companies, 1988-1994 . . . . . . . 110

B35. Distribution of Foreign Exploration and Development Expenditures for FRS Companies Ranked by Total Energy Assets, 1994, and Percent Change from 1993 . . . . . . . . . . . . . . . . . . . 111

B36. Number of Net Wells Completed, Net In-Progress Wells, and Net Producing Wells in Foreign

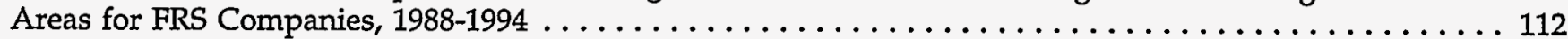

B37. Foreign Proved Oil and Gas Reserves for FRS Companies, $1994 \ldots \ldots \ldots \ldots \ldots \ldots \ldots \ldots \ldots \ldots \ldots$

B38. Foreign Production (Lifting) Costs for FRS Companies, 1988-1994 . . . . . . . . . . . . . . . 115

B39. U.S. Refining/Marketing Dispositions of Refined Products by Channel of Distribution for

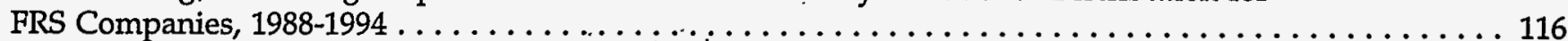

B40. Sales of U.S. Refined Products, by Volume and Price, for FRS Companies Ranked by

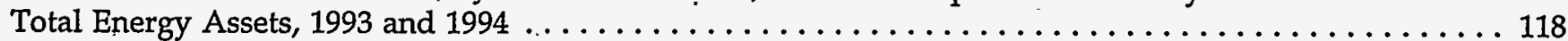

B41. U.S. Petroleum Refining/Marketing, General Operating Expenses for FRS Companies, 1988-1994 . . . . . 119

B42. U.S. Petroleum Segments Purchases and Sales of Raw Materials and Refined Products for

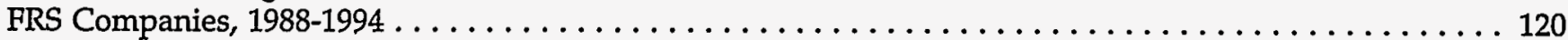

B43. U.S. and Foreign Refining/Marketing Segment, Sources and Dispositions of Crude Oil and Natural Gas Liquids for FRS Companies, $1988-1994 \ldots \ldots \ldots \ldots \ldots \ldots \ldots \ldots \ldots \ldots \ldots \ldots \ldots \ldots$

B44. U.S. and Foreign Oil Raw Materials Balance for FRS Companies Ranked by Total Energy Assets,

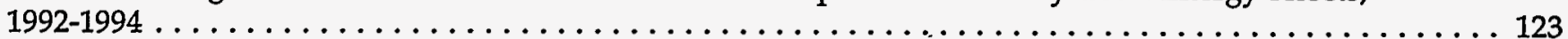

B45. U.S. Refinery Output and Refinery Capacity Statistics for FRS Companies, Ranked by Total Energy Assets, and for U.S. Industry, 1993 and 1994 
B46. Foreign Refinery Output and Refinery Capacity Statistics for FRS Companies, Ranked by

Total Energy Assets, and for Foreign Industry, 1993 and $1994 \ldots \ldots \ldots \ldots \ldots \ldots \ldots \ldots \ldots$. . . . . . . . . . 125

B47. U.S. and Foreign Petroleum Refining Statistics for FRS Companies, $1988-1994 \ldots \ldots \ldots \ldots \ldots \ldots \ldots \ldots$

B48. U.S. Refining/Marketing Revenues and Costs for FRS Companies, 1992-1994 . . . . . . . . . . . . . 127

B49. Sources of U.S. Bituminous Coal and Lignite Production, by Region and Mining Method,

for FRS Companies and U.S. Industry, 1994, and Percent Change From 1993 . . . . . . . . . . . . . 128

B50. U.S. Coal Reserves Balance for FRS Companies, $1988-1994$. . . . . . . . . . . . . . . . . . . . . . . 129

B51. U.S. Coal Reserves (End of Year) and Production Statistics for FRS Companies, 1988-1994 . . . . . ..... 130

B52. Research and Development Expenditures for FRS Companies, 1988-1994 . . . . . . . . . . . . 131

\section{Illustrations}

1. Operating Revenues by Line of Business for FRS Companies, $1981-1994 \ldots \ldots \ldots \ldots \ldots \ldots \ldots \ldots$

2. Shares of U.S. Energy Production and Refinery Capacity for FRS Companies, 1981-1994 ... . . . . . . . . 3

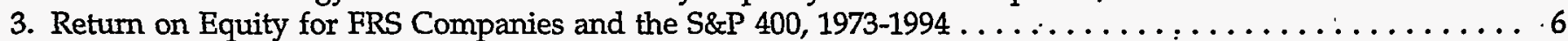

4. Revenues and Operating Expenses for the Chemical Segment for FRS Companies, 1981-1994 . . . . . . . 8

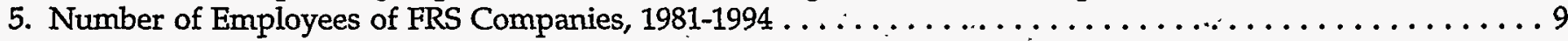

6. Downsizing Reduces Operating Costs . . . . . . . . . . . . . . . . . . . . . . . . . .

7. Additions to Investment in Place and Value of Acquisitions and Mergers for FRS Companies, 1974-1994 .. 13

8. Worldwide Effective Income Tax Rates for FRS Companies and S\&P 400, 1981-1994 . . . . . . . . . 15

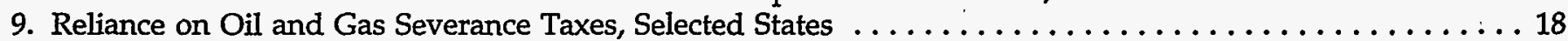

10. FRS Companies' Shares of U.S. Oil and Gas Severance Taxes and Wellhead Revenues . . . . . . . . . 18

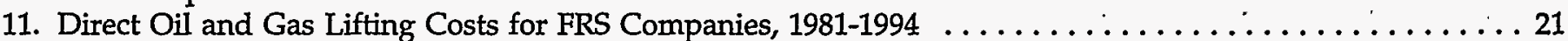

12. Rates of Return in U.S. and Foreign Oil and Gas Production for FRS Companies, 1981-1994 . . . . . . . 21

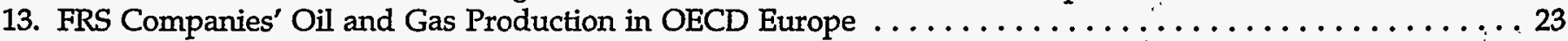

14. Exploration and Development Expenditures for FRS Companies, $1981-1994 \ldots \ldots \ldots \ldots \ldots \ldots \ldots$

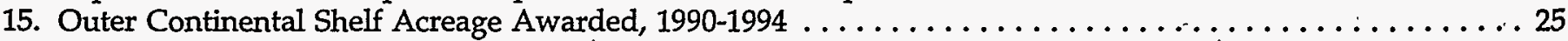

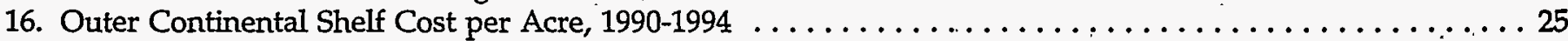

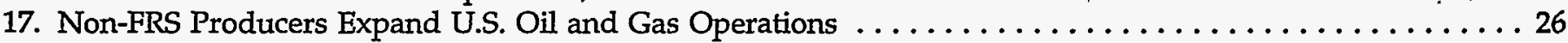

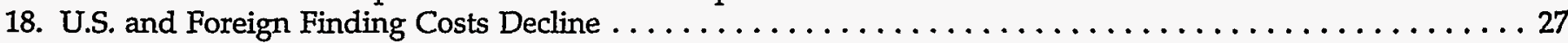

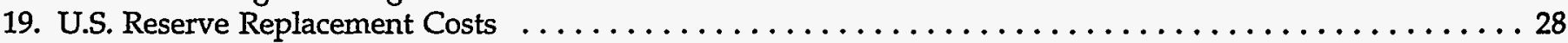

20. U.S. Refining Pollution Abatement Costs as a Share of Costs and Expenditures for the FRS Companies,

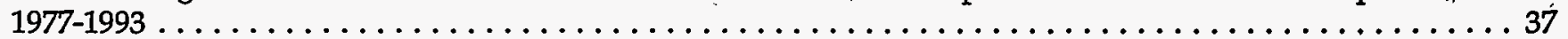

21. Net PP\&E per Unit of Refinery Capacity for FRS Companies, 1974-1994 . . . . . . . . . . . . . .37

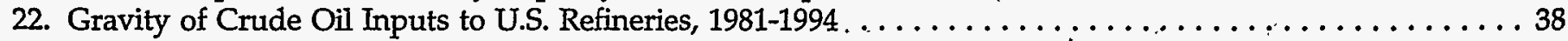

23. Average Sulfur Content of Crude Oil Inputs to U.S. Refineries, $1981-1994 \ldots \ldots \ldots \ldots \ldots \ldots \ldots$. . . . . . 38

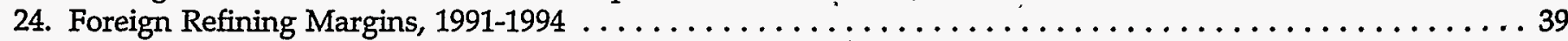

25. World Petroleum Consumption, by Region, 1990 and 1994 . . . . . . . . . . . . . . . . . . 39

26. FRS Company Exploration and Development Expenditures in Other Western Hemisphere Nations, 1987-1994 56 


\section{Executive Summary}

Performance Profiles of Major Energy Producers 1994 is the eighteenth annual report of the Energy Information Administration's (ELA) Financial Reporting System (FRS). The report examines financial and operating developments in energy markets, with particular reference to the 24 major U.S. energy companies required to report annually on Form ELA-28 (see the box entitled "The FRS Companies in 1994," page 2). Financial information is reported by major lines of business, including oil and gas production, petroleum refining and marketing, other energy operations, and nonenergy businesses. Financial and operating results are presented in the context of energy market developments with a view toward identifying changing corporate strategies and measuring the performance of ongoing operations both in the United States and abroad. Main developments in 1994 are described below.

\section{Chemical Operations and Cost Cutting Produce Income Gains}

In 1994, a year characterized by generally lower petroleum and natural gas prices despite improved worldwide economic growth, net income (excluding unusual items) of the FRS companies increased 10 percent to $\$ 19.3$ billion. Chemical operations largely accounted for the gain in income. In worldwide petroleum operations, slight gains in income from oil and gas production could not quite offset the effects of a poor year for refining operations. On balance, income from petroleum operations was down 4 percent between 1993 and 1994. Across a number of lines of business, lower operating costs contributed to improved financial results.

In the 1990's so far, nearly all of the FRS companies have reduced the scale of their operations, a process often termed "downsizing." For example, from 1990 to 1994, overall FRS employment was down by 165 thousand, or 20 percent. Downsizing in the 1990's generally involved consolidation of core operations, in contrast to the restructurings of the 1980's which often included divestitures of entire lines of business. An exception in the 1990's was U.S. coal production, with six FRS companies exiting this industry entirely.

Downsizing is undertaken to lower costs and thereby increase current and future expected profitability. In 1994, cost cutting was clearly evident in oil and gas production, U.S. refining and marketing, and coal production.

Although cost cutting can improve current profits, continual shrinkage is not a long-run strategy for increased profits and shareholder value. Growth, efficiency, and the strategic deployment of assets are essential to longrun corporate viability. Several sources of growth for the FRS companies were evident in 1994, cutting across a number of lines of business. These sources included natural gas markets, applications of technology, and privatization of formerly State-owned energy resources.

\section{Natural Gas Markets Grow}

The FRS companies' total capital expenditures in 1994 were $\$ 39.1$ billion, a dip of 3 percent from expenditures in 1993. Although 1994 featured the lowest real oil prices in 21 years, and the wellhead price of natural gas was also low in historical terms, long-term prospects of increases in demand and improvements in exploration and production technology led to a modest resurgence in, expenditures for U.S. oil and gas. In 1994, U.S. upstream (exploration, development, and production) expenditures exceeded foreign upstream expenditures, reversing the pattern of 1992 and 1993. The 15-percent increase in U.S. upstream expenditures was traceable to acquisitions of mainly natural gas properties and increased natural gas drilling. Canadian natural gas was also an investment target of a majority of the FRS companies, as their Canadian natural gas well completions were up 54 percent in 1994 following a fourfold increase in 1993.

Growth in demand has been a key element in increased investment in natural gas by the FRS companies. In the United States, cogeneration and other nonutility electric power producers accounted for nearly 50 percent of the growth in natural gas demand in the 1990's. Growth in capacity to deliver exports to the lower 48 States has largely driven the interest in Canadian natural gas. Outside North America, growth in demand for liquefied natural gas and natural gas liquids in the Asia-Pacific Rim area has encouraged a number of FRS companies to make sizable investments in this region.

Moving from regulated to competitive natural gas markets in the United States led to greater involvement 
of the FRS companies in natural gas. In particular, the unbundling of natural gas sales from natural gas transport has opened natural gas marketing opportunities for producers. The resale of natural gas was clearly a growing component of FRS domestic upstream revenues in 1994.

\section{Payoffs Evident from Advances in Technology}

The FRS companies added 5.7 billion barrels of oil and gas (crude oil equivalent) in 1994 to their worldwide reserves (excluding the effects of purchase and sales of previously discovered reserves), a record total for the 21 years of FRS data collection. This performance was sufficient to replace 109 percent of their overall oil and gas production. Further, the cost of adding to the reserve base continued to decline in 1994 , to $\$ 4.69$ per barrel, down by over 10 percent from the cost in 1993. The FRS companies' costs of adding reserves were down in nearly every producing region.

A number of technological developments contributed to lower costs of adding oil and gas reserves. Threedimensional seismic techniques enabled geologists to successfully access hydrocarbons beneath salt sheets in the Gulf of Mexico. Improvements in platform design have reduced the cost of deepwater resource development. These technological innovations provided a foundation for cost-effective exploitation of U.S. offshore reserves and led to an increase in bidding for Outer Continental Shelf acreage in 1994.

Other areas of energy production also benefitted from applications of advancing technology. Operating costs for remaining FRS coal-producers were reduced by $\$ 2$ per ton in 1994, largely offsetting the effects of lower coal prices. This improvement was in part attributable to continuing innovations in longwall mining systems. One of the growing areas in the "other energy" line of business involves electrical generation through the relatively new technologies of cogeneration and combined cycle gas turbines. Production of oil from Canadian tar sands, a mainstay of FRS nonconventional energy activity, recently benefitted from the installation of more efficient extraction technology.

The FRS companies faced technological challenges as well as opportunities in 1994. The Clean Air Act Amendments of 1990 require reformulated gasoline, designed to reduce airborne toxics and volatile organic compounds, to be supplied in certain of the larger U.S. gasoline markets by January 1, 1995. Since 1990, environmentally-related investments have accounted for an increasing share of the FRS companies' capital expenditures for U.S. refining facilities. The most recent data indicate that, in 1993, environmentally-related capital expenditures accounted for 40 percent of the FRS companies' $\$ 4.5$ billion in expenditures for U.S. refining.

\section{Privatization Opens New Opportunities}

Over the past several years, a number of countries have privatized their state-owned energy companies. In part, the roots of such privatizations lay in the globalization of the. world's economies and the growth in international trade and investment. In part, these privatizations were also spurred by the demise of communism in Eastern Europe and the Former Soviet Union (FSU) and the growing conviction that free enterprise advances the wealth of nations better than nationalized industries and state-planned economies. Upstream, privatization offers opportunities to add oil and gas reserves of a magnitude unseen since the explorations of Prudhoe Bay and the North Sea. Downstream, major privatization efforts are-underway in some of the world's fastest growing refined product markets.

For the FRS companies, these privatizations may turn out to be one of the most important developments in world petroleum markets in recent times. This report includes a review of privatization efforts currently underway in China, the,FSU, and Latin America, with an emphasis on FRS company involvement.

Due to recent privatizations, the FRS companies have entered into a variety of oil and gas activities in China, the FSU, and Latin America. Perhaps most prominent (and potentially promising).. among the upstream activities is Chevron's 50-50 joint venture in Kazakhstan to develop the Tengiz Field. Chevron estimates that production from this field will eventually reach 700,000 barrels per day. ARCO proved a pathbreaker in being the first western company to purchase shares in a recently privatized Russian oil company. In addition, ARCO purchased a portion of a refinery in China in 1994. Privatization has also sparked new interest in creating vast regional natural gas pipeline networks. Currently, natural gas pipeline networks crisscrossing Asia and Latin America are on the drawing boards, and FRS companies are involved. Nonconventional energy, such as cogeneration, has also been a target of investment in privatizing countries, particularly among some of the FRS companies prominent in cogeneration in the United States. 


\section{Energy Markets in 1994}

The 24 companies reporting to the Energy Information Administration's (EIA) Financial Reporting System (FRS) (see the box entitled "The FRS Companies in 1994" on page 2) derive the bulk of their revenues and income from petroleum operations, including natural gas production (see the box entitled "The FRS Companies in the U.S. Economy and Energy Markets" on page 3). ${ }^{1}$ A majority of FRS companies are multinational, with over a third of their net investment located abroad. Worldwide petroleum and natural gas market developments are of primary importance to the FRS companies' financial performance. Developments in chemical markets are also important in that 16 FRS companies have asset commitments in chemical manufacturing. Over recent years, reducing costs through consolidation of ongoing businesses and restructuring has had a pronounced effect on financial performance. In fact, the modest improvement in the FRS companies' overall income in 1994 was largely traceable to a surge in earnings from chemicals and reductions in operating costs. Demand and supply developments in energy markets had mixed effects on the FRS companies' financial performance in 1994.

Economic growth is an important determinant of energy demand. For many nations, economic growth picked up in 1994 compared with growth in recent years. The United States stood out among the industrialized nations, with an annual growth in real Gross Domestic Product (GDP) of 4.1 percent. $^{2}$ Other areas registering even higher rates of growth were the Pacific Rim (particularly China but excluding Japan) and most of Latin America. In contrast, European growth was mixed, while the countries of the Former Soviet Union (FSU) again experienced economic decline. The GDP of the FSU fell 9 percent in 1994, following declines of 12 percent in 1993 and 16 percent in 1992. Excluding the FSU, world GDP was up 3.4 percent in 1994.
The generally favorable course of economic growth in 1994 tended to increase the demand for oil. Excluding the FSU, world oil consumption increased 3.4 percent. Increased demand put upward pressures on oil prices, which, in 1993, had fallen from a range of $\$ 16$ to $\$ 18$ per barrel for much of the year to less than $\$ 13$ in December (measured by the refiner acquisition cost of imported crude oil). Oil supplies, however, were ample. During 1994, most members of the Organization of Petroleum Exporting Countries (OPEC) were able to hold output steady. Outside OPEC, increased North Sea oil production served largely to offset declining oil production in the United States and the FSU. Although crude oil prices rose from their unusually low first quarter level of $\$ 13$ per barrel to the $\$ 16$ to $\$ 17$ range for most of the year, crude oil prices on an annual basis in 1994 were still down somewhat more than a dollar per barrel from 1993, both in the United States and abroad.

Demand for natural gas was up as well in 1994. World natural gas consumption, excluding the FSU, increased 2.9 percent between 1993 and 1994. In the United States, natural gas demand was up 2 percent, due mostly to a sharp increase in natural gas usage by electrical utilities. Residential demand, however, was moderated somewhat by mild winter weather in 1994, the effects of which were somewhat exaggerated in comparisons with 1993's extraordinarily severe winter weather. Between 1993 and 1994, U.S. natural gas production rose by over 3 percent-the highest rate of growth since 1986. Much of this increase came from offshore fields in the Gulf of Mexico, where the FRS companies are responsible for a majority of production. Growth in U.S. natural gas production and imports outstripped demand, leading to downward pressures on prices received by producers; domestic natural gas wellhead prices registered a 10percent decline, on an annual basis, from 1993 to 1994.

\footnotetext{
'The companies that reported to the FRS system for the years 1974 through 1994 are listed in Appendix A, Table A1. Three of the FRS companies are majority-owned by foreign companies: BP America-100-percent owned by British Petroleum, Fina-79-percent owned by Petrofina, and Shell Oil-100-percent owned by Royal Dutch/Shell.

${ }^{2}$ In this chapter, international energy data were obtained from British Petroleum Company, p.l.c., BP Statistical Review of World Energy (London, June 1995); annual U.S. energy industry price and quantity data are from the Energy Information Administration, Annual Energy Review, 1994, DOE/EIA-0384(94) (Washington, DC, July 1995); monthly data are from Energy Information Administration, Monthly Energy Review, DOE/EIA-0035(95/09) (Washington, DC, September 1995); GDP data are from the WEFA Group, World Economic Outlook, July 1995; and refining margin data are from the Energy Information Administration, U.S. Energy Financial Developments, 1995 First Quarter, DOE/EIA-0543(95/1Q) (Washington, DC, June 1995); offshore natural gas production data are from the Energy Information Administration, U.S. Crude Oil, Natural Gas, and Natural Gas Liquids Reserves 1994 Annual Report, DOE/EIA-0216(94) (Washington, DC, October 1995).
} 
Abroad, the FRS companies reported a mixed pattern of prices which, overall, resulted in flat natural gas prices from 1993 to 1994.

Although market developments tended to yield lower oil and natural gas prices for producers, the FRS companies partly offset the effects of lower prices on their upstream operations (exploration, development, and production) through cost cutting, increased natural gas production, and, in their foreign operations, through increased oil production.

The rise in oil prices following the first quarter of 1994 narrowed the margin between U.S. refined product prices and crude oil input costs, despite a 3-percent increase in U.S. product demand. A surge in light product (gasoline, distillate, and jet fuel) imports, especially in the second and third quarters of 1994, impaired U.S. refiners' efforts to fully recover higher crude oil costs. Tightness in U.S. refining capacity and Trans-Atlantic product price differentials encouraged gasoline imports. Increased gasoline imports also reflected U.S. refiners' reluctance to produce and stock summer-grade gasoline in the face of requirements to supply reformulated gasoline (RFG) by January 1, 1995. The margin between overall refined product prices and crude oil input costs for the last three quarters of 1994 was about a dollar less than the comparable period in 1993. Refining margins declined abroad as well, particularly in the Asia-Pacific region. Cost cutting by FRS refiners was evident in U.S. operations but was insufficient to offset the effects of squeezed margins.
Chemical manufacture is an important source of income for a majority of the FRS companies. For example, in 1994, chemical operations accounted for 12 percent of all of the FRS companies' net assets. After four years of declining price-cost margins and excess capacity, the chemical industry, particularly petrochemicals, experienced sharp upswings in demand and profits. The FRS companies with chemical operations benefitted greatly from this boom.

This report reviews the FRS companies' 1994 financial performance and corporate strategies in the context of domestic and foreign energy market developments. Chapter 2 presents an overview of sources of income, cash flow, taxation, and deployment of funds, including investment patterns across lines of business. Chapter 3 reviews the FRS companies' performance in oil and gas exploration, development, and production from a global perspective. Chapter 4 examines developments in the FRS companies' worldwide petroleum refining, marketing, and transport activities. Chapter 5 reviews the FRS companies involvement in energy sources other than petroleum and natural gas. Chapter 6 presents some results, including information for 1995, of an ongoing study of the opportunities for energy investment afforded by recent privatization initiatives in China, the FSU, and Latin America, with particular reference to the FRS companies' targets of investment. Appendix A describes the structure of the FRS data collection system, and Appendix B presents detailed statistical tables. A glossary provides key definitions.

\section{The FRS Companies in 1994}

Amerada Hess Corporation

Amoco Corporation

Anadarko Petroleum, Inc.

Ashland Oil, Inc.

Atlantic Richfield Company (ARCO)

BP America, Inc.

Burlington Resources, Inc.

Chevron Corporation

Coastal Corporation

E.l. du Pont de Nemours and Company

Enron Corporation

Exxon Corporation
Fina, Inc.

Kerr-McGee Corporation

Mobil Corporation

Occidental Petroleum Corporation

Oryx Energy Company

Phillips Petroleum Company

Shell Oil Company

Sun Company, Inc.

Texaco, Inc.

Union Pacific Corporation

Unocal Corporation

USX Corporation 


\section{The FRS Companies in the U.S. Economy and Energy Markets}

Major energy-producing companies annually report to the Energy Information Administration (EIA) on Form EIA-28. These reports include data and information on financial and operating developments. For the reporting year 1994, 24 companies filed this information. ${ }^{a}$

The FRS companies occupy a major position in the U.S. ${ }^{b}$ economy. In 1994, their sales equaled 10 percent of the $\$ 4.3$ trillion in sales of the Fortune 500 largest U.S. corporations. ${ }^{c}$ Of the top 25 companies (based on sales) on the Fortune 500 list in 1994, 6 were FRS companies.

The reporting companies engage in a wide range of business activities, but their most important activities are in the energy sector. About 82 percent, or $\$ 374$ billion, of allocated operating revenues were derived from energy sales. Nearly all of these sales involved petroleum (Figure 1). (For purposes of this report, petroleum is defined to include natural gas.)

Figure 1. Operating Revenues by Line of Business for FRS Companies, 1981-1994

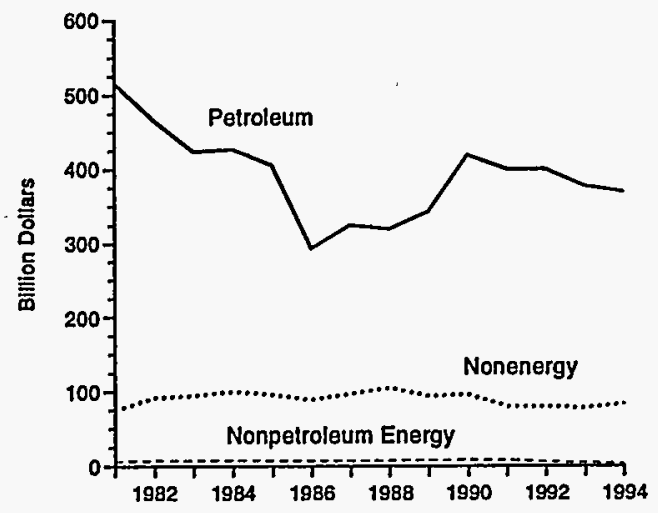

Note: Petroleum includes natural gas.

Source: Energy Information Administration, Form ElA-28.
In 1994, the FRS companies accounted for 52 percent of total U.S. crude oil and natural gas liquids (NGL) production, 44 percent of U.S. natural gas production, and 65 percent of U.S. refinery capacity (Figure 2). The bulk of the FRS companies' assets and new investments is devoted to sustaining various aspects of petroleum production, processing, transportation, and marketing. Nonenergy businesses accounted for about 18 percent, or $\$ 83$ billion, of the FRS companies' allocated revenues in 1994.

Energy production other than oil and natural gas is a relatively small part of the FRS companies' operations. The combined operating revenues of coal and other energy operations of the FRS companies totaled $\$ 4$ billion in 1994, or only 1 percent of allocated revenues. Nonetheless, the FRS companies are significant participants in the coal market, producing 17 percent of U.S. coal in 1994. The FRS companies no longer produce uranium oxide domestically.

Figure 2. Shares of U.S. Energy Production and Refinery Capacity for FRS Companies, 1981-1994

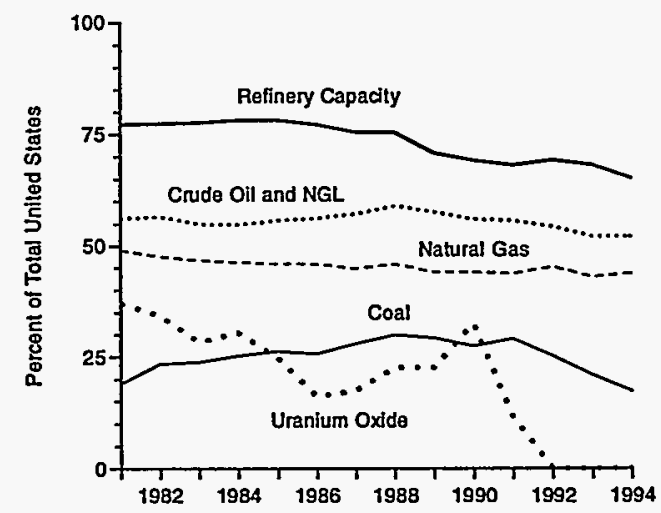

Source: See Appendix B, Table B1.

\footnotetext{
aggregate time series data from Form EIA-28 for 1977 through 1994 can be obtained from the EIA (see contacts, p. ii) on paper or diskette.

'For purposes of this report, the term "United States" typically includes the 50 States, the District of Columbia, Puerto Rico, and the U.S. Virgin Islands.

The Fortune 500 is a list of the 500 largest U.S. industrial companies, ranked by total sales, published annually by Fortune magazine. Prior to the 1994 listing, companies had to obtain a majority of their sales revenues from manufacturing/mining, including oil production and refining. That is, prior to 1994, only industrial companies were included. Among the top 25 U.S. industrial corporations (including Shell Oil) in 1994, 8 were FRS companies, down from 9 in 1993.
} 
if.

I 


\section{Key Financial Developments}

\section{Sources of Income}

Net income of the 24 major energy companies reporting to the Energy Information Administration's (EIA) Financial Reporting System (FRS) rose 10 percent, to $\$ 19.3$ billion (excluding unusual items ${ }^{3}$ ), in 1994. Revenues of $\$ 446.6$ billion were virtually unchanged from revenues in 1993 (Table 1). Among lines of business, chemicals were the primary source of higher income. Overall corporate profitability of the FRS companies, as measured by return on stockholders' equity, improved slightly (Figure 3). However, the rest of U.S. industry, as represented by the Standard and Poor's group of 400 industrial companies (S\&P 400), soared to the highest level of profitability in over 20 years. This improvement reflected strong economic growth in 1994 and the payoffs to restructuring initiated in recent years.
The FRS companies also benefitted from restructuring, with reduced operating costs contributing to earnings in several lines of business. However, the benefits of economic growth on overall petroleum profits were offset by plentiful supply capabilities that tended to reduce prices and profit margins.

\section{Chemicals Produce Upswing in Profits}

The nonenergy line of business, which consists of chemical manufacturing and diversified activities other than energy, contributed $\$ 7.2$ billion (excluding unusual items) to net income in 1994, up $\$ 3.1$ billion from 1993 (Table 2), and yielded the highest rate of return among the lines of business (Table 3). ${ }^{5}$ The year 1994 marked an economic rebound for chemical manufacturing, especially petrochemicals. This turnaround came after several years of

Table 1. Consolidated Income Statement for FRS Companies, 1993 and 1994

(Billion Dollars)

\begin{tabular}{|c|c|c|c|}
\hline Income Statement Items & 1993 & 1994 & $\begin{array}{c}\text { Percent Change } \\
1993-1994\end{array}$ \\
\hline Operating Revenues & 448.1 & 446.6 & -0.3 \\
\hline Operating Expenses $\ldots \ldots \ldots \ldots \ldots \ldots \ldots \ldots \ldots$ & -423.0 & -416.5 & -1.5 \\
\hline Operating income $\ldots \ldots \ldots \ldots \ldots \ldots \ldots \ldots$ & 25.1 & 30.1 & 19.9 \\
\hline Interest Expense $\ldots \ldots \ldots \ldots$ & -7.9 & -7.9 & 0.5 \\
\hline Other Revenue (Expense) $\ldots \ldots \ldots \ldots \ldots$ & 7.4 & 5.0 & -32.4 \\
\hline Income Tax Expense $\ldots \ldots \ldots \ldots \ldots \ldots \ldots \ldots$ & -9.1 & -10.6 & 16.3 \\
\hline Net Income $\ldots \ldots \ldots \ldots \ldots \ldots \ldots \ldots \ldots$ & 15.5 & 16.5 & 6.8 \\
\hline Net Income Excluding Unusual Items $\ldots \ldots$. & 17.6 & 19.3 & 9.6 \\
\hline
\end{tabular}

Note: Sum of components may not equal total due to independent rounding. Percent changes were calculated from unrounded data.

Source: Energy Information Administration, Form EIA-28.

${ }^{3}$ Unusual items are composed of gains and charges recognized in a company's income statement that are of a non-recurring nature and generally unrelated to current operations. These items include effects of accounting changes, litigation settlements, gains and losses from large divestitures of assets, provisions for the cost of restructuring, and provisions of reserves for future liabilities.

${ }^{4}$ The S\&P 400 is a well recognized database that includes 400 of the largest U.S. industrial companies. In 1994, 19 of the FRS companies were included in the S\&P 400 . Financial statistics for the S\&P 400 were obtained by accessing Compustat, a service of Standard \& Poor's, Inc.

${ }^{5}$ Line-of-business profit measures should be distinguished from measures that reflect company-wide results because the former reflect only allocated income, expense, and asset items. Two measures of income are presented: operating income and contribution to net income. Operating income by line of business is similar in concept to the operating income measure for total company operations. It is the net of operating revenues and operating expenses (including depreciation, depletion, and amortization) for a line of business. Contribution to net income equals operating income plus income from unconsolidated affiliates and gains on disposal of property, plant, and equipment, less income taxes imputed to the line of business and excludes certain non-allocable items, primarily interest expense. Interest expense is the principal source of difference between a companywide net income figure and line-of-business contributions to net income (see Appendix A for further discussion). Line-of-business rates of return are based on historical costs and measure average profitability, not marginal or prospective rates of return. 
Figure 3. Return on Equity for FRS Companies and the S\&P 400, 1973-1994

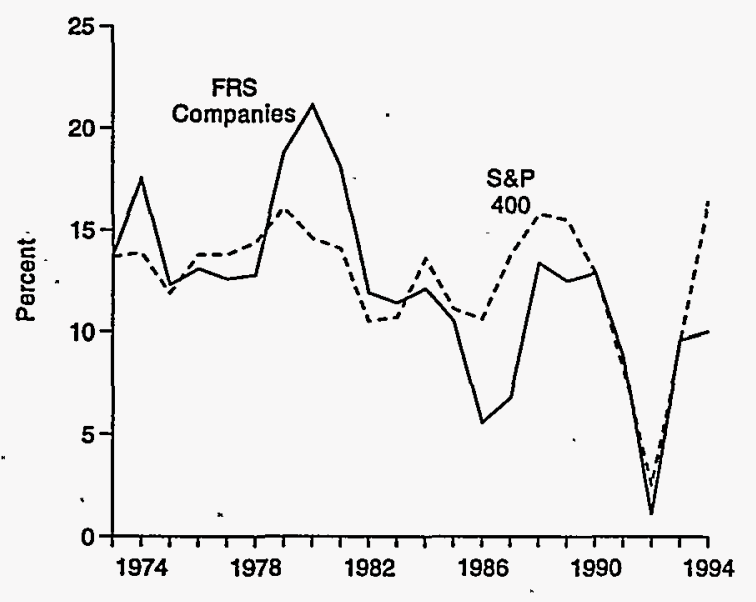

Sources: FRS Companies: Energy Information Administration, Form ElA-28. S\&P 400: Standard \& Poor's Compustat Service.

excess capacity and declining profits. Improved economic growth in much of the world (Chapter 1) led to increased demand, and supplies were tightened by a number of capacity outages in $1994 .^{6}$ All 16 FRS chemical manufacturers reported increased income from these operations, typically citing a wider spread between prices and costs and greater sales volumes. Figure 4 shows that operating expenses were nearly unchanged, while chemical sales rose sharply in 1994. Accordingly, operating income from the FRS companies' chemical operations more than doubled between 1993 and 1994 (Table 4).?

The balance of the nonenergy line of business encompasses a variety of enterprises. Operating income, overall, for these activities was up 53 percent. Areas of improvement included metals and railroading. For example, USX stated, " . . . operating results in 1994 improved . . . over 1993 primarily due to higher steel prices and shipment volumes," and Exxon noted, "Metals prices rebounded strongly in 1994 after prices were depressed through most of 1993 .... Demand for metals increased, especially in the
United States:"8 According to Union Pacific's Chief Executive Officer, "Car loadings were up over 8 percent .... Shipments across the board were strong except for grain ...."

A poor year for petroleum refining and marketing, both in the United States and abroad, pulled down overall petroleum profits in 1994. Net income (excluding unusual items) from the FRS companies' worldwide refining/ marketing operations fell $\$ 1.4$ billion from 1993's results (Table 2). In the United States, the margin between refined product prices and crude oil input costs deteriorated during the last nine months of 1994. Although FRS refiners noticeably trimmed operating expenses, their cost-cutting efforts did not fully offset the effects of lower margins. Also, Federal requirements to supply reformulated gasoline by January 1, 1995, had adverse impacts on 1994 refiner profits. The added cost of producing reformulated gasoline in the latter part of 1994 was not fully recoverable until the product could be sold in 1995. Lower refining margins in Asia and Europe contributed to lower downstream (refining, marketing, and transport) income from abroad.

Oil and gas prices at the U.S. wellhead in 1994 each averaged somewhat over a dollar per barrel (crude oil equivalent) less than prices in $1993 .{ }^{10}$ The FRS companies managed to squeeze out a 5 -percent increase in net income (excluding unusual items) from U.S. oil and gas production despite lower oil and gas prices. The FRS companies offset lower prices and reduced oil production through cost cutting and increased natural gas production. Lower taxes also contributed to improved results in U.S. upstream operations.

In foreign oil and gas production, net income (excluding unusual items) was also up only 5 percent. The main' source of financial improvement was traceable to increased oil and gas production abroad, up 7 percent on a combined basis. Cost cutting was of less importance than it was in the United States. Further, the overall rate of taxation on foreign production income increased in 1994, unlike the United States, where the effective income tax rate on oil and gas production was lower.

\footnotetext{
6"Profits Boom, but What Will Next Year Bring?" Petroleum Economist (August 1995), pp. 3-5.

${ }^{7}$ For FRS purposes, separate reporting of income for chemical and other nonenergy segments was discontinued beginning with the 1987 reporting year. However, the disclosures of chemical segment revenues and operating income made by the FRS companies in their annual reports to shareholders closely track, in the aggregate, the comparable disclosures in the Form EIA-28 from 1981 through 1986. Thus the public disclosures of chemical segment revenue and operating income were utilized for 1987 through 1994. Revenues and operating income for the other nonenergy segment after the 1986 reporting year were obtained by subtracting the publicly disclosed chemical segment values from the nonenergy line-of-business values reported on Form EIA-28. It should be noted that the results for chemicals are qualitatively unchanged if DuPont, the largest FRS chemical producer, is excluded.

${ }^{8}$ USX Corporation, Securities and Exchange Commission Form 10-K, p. S-23, and Exxon Corporation, Financial and Operating Review 1994, pp. 69-70.

${ }^{9}$ Union Pacific Corporation, 1994 Annual Report, p. 2.

${ }^{10}$ Unless otherwise noted, energy industry price and quantity data are from Energy Information Administration, Monthly Energy Review, DOE/EIA-0035(95/09) (Washington, DC, September 1995).
} 
Table 2. Contributions to Net Income by Line of Business for FRS Companies, 1993-1994 (Million Dollars)

\begin{tabular}{|c|c|c|c|c|c|c|}
\hline \multirow[b]{2}{*}{ Line of Business } & \multicolumn{3}{|c|}{ Net Income } & \multicolumn{3}{|c|}{ Net Income Excluding Unusual Items } \\
\hline & 1993 & 1994 & $\begin{array}{c}\text { Percent Change } \\
\text { 1993-1994 }\end{array}$ & 1993 & 1994 & $\begin{array}{c}\text { Percent Change } \\
\text { 1993-1994 }\end{array}$ \\
\hline \multicolumn{7}{|l|}{$\begin{array}{l}\text { Petroleum } \\
\text { U.S. Petroleum }\end{array}$} \\
\hline Production.,$\ldots \ldots \ldots$ & 4,839 & 4,780 & -1.2 & 5,485 & 5,761 & 5.0 \\
\hline Refining/Marketing $\ldots \ldots \ldots \ldots$ & 1,685 & 1,845 & 9.5 & 2,911 & 2,290 & -21.3 \\
\hline Pipelines $\ldots \ldots \ldots \ldots \ldots \ldots$. & 1,566 & 1,833 & 17.0 & 1,568 & 1,747 & 11.4 \\
\hline Total U.S. Petroleum $\ldots . . \ldots$ & 8,090 & 8,458 & 4.5 & 9,964 & 9,798 & -1.7 \\
\hline \multicolumn{7}{|l|}{ Foreign Petroleum } \\
\hline Production $\ldots . .$. & 5,160 & 3,975 & -23.0 & 4,254 & 4,461 & 4.9 \\
\hline Refining/Marketing & 3,193 & 1,997 & -37.5 & 3,496 & 2,743 & -21.5 \\
\hline International Marine & 21 & -33 & -. & 21 & -33 & -- \\
\hline Total Foreign Petroleum ...... & 8,374 & 5,939 & -29.1 & 7,771 & 7,173 & -7.7 \\
\hline Total Petroleum & 16,463 & 14,397 & -12.5 & 17,734 & 16,969 & -4.3 \\
\hline Coal. . & 371 & 163 & -56.1 & 195 & 289 & 48.2 \\
\hline Other Energy $\ldots \ldots \ldots \ldots \ldots \ldots$ & 121 & 151 & 24.8 & 102 & 157 & 53.9 \\
\hline Nonenergy $\ldots \ldots \ldots \ldots \ldots \ldots$ & 2,699 & 6,171 & 128.6 & 4,072 & 7,156 & 75.7 \\
\hline Total Allocated .... & 19,654 & 20,882 & 6.2 & 22,103 & 24,571 & 11.2 \\
\hline Nontraceables and Eliminations .... & $-4,166$ & $-4,335$ & -- & $-4,462$ & $-5,238$ & -- \\
\hline Consolidated Net Income ${ }^{\mathrm{a}}$ & 15,488 & 16,547 & 6.8 & 17,641 & 19,333 & 9.6 \\
\hline
\end{tabular}

${ }^{a}$ The total amount of unusual items was $-\$ 2,153$ million and $-\$ 2,786$ million in 1993 and 1994 , respectively.

$--=$ Not meaningful.

Note: In petroleum, the sum of components may not equal total due to nontraceables and eliminations.

Source: Energy Information Administration, Form ElA-28.

Table 3. Rates of Return by Line of Business for FRS Companies, 1986-1994 (Percent)

\begin{tabular}{|c|c|c|c|c|c|c|c|c|c|}
\hline Line of Business & 1986 & 1987 & 1988 & 1989 & 1990 & 1991 & 1992 & 1993 & 1994 \\
\hline Petroleum . & 5.5 & 6.2 & 7.3 & 6.7 & 9.5 & 7.0 & 5.6 & $6.4^{\circ}$ & 5.6 \\
\hline $\begin{array}{l}\text { U.S. Petroleum ............. } \\
\text { Oil and Gas Production } \ldots \ldots \ldots \\
\text { Refining/Marketing } \ldots \ldots \ldots \ldots \\
\text { Pipelines } \ldots \ldots \ldots \ldots \ldots\end{array}$ & $\begin{array}{r}3.0 \\
0.8 \\
4.5 \\
13.2\end{array}$ & $\begin{array}{r}4.9 \\
4.1 \\
2.9 \\
12.8\end{array}$ & $\begin{array}{r}6.3 \\
2.8 \\
14.7 \\
9.6\end{array}$ & $\begin{array}{r}5.8 \\
2.9 \\
11.5 \\
10.2\end{array}$ & $\begin{array}{r}7.9 \\
8.5 \\
5.1 \\
11.2\end{array}$ & $\begin{array}{r}4.9 \\
5.1 \\
2.0 \\
10.7\end{array}$ & $\begin{array}{r}4.4 \\
5.9 \\
-0.4 \\
8.4\end{array}$ & $\begin{array}{l}4.9 \\
5.3 \\
3.4 \\
6.4\end{array}$ & $\begin{array}{l}5.2 \\
5.5 \\
3.6 \\
7.6\end{array}$ \\
\hline $\begin{array}{l}\text { Foreign Petroleum } \ldots \ldots \ldots \ldots \\
\text { Oil and Gas Production } \ldots \ldots \ldots \\
\text { Refining/Marketing } \ldots \ldots \ldots \\
\text { International Marine } \ldots \ldots \ldots\end{array}$ & $\begin{array}{r}12.8 \\
11.6 \\
16.3 \\
5.3\end{array}$ & $\begin{array}{r}9.5 \\
12.4 \\
4.7 \\
-3.6\end{array}$ & $\begin{array}{r}9.9 \\
9.2 \\
11.6 \\
6.8\end{array}$ & $\begin{array}{r}8.7 \\
8.9 \\
8.0 \\
12.4\end{array}$ & $\begin{array}{l}12.5 \\
13.1 \\
11.2 \\
11.7\end{array}$ & $\begin{array}{r}11.0 \\
9.1 \\
14.6 \\
15.6\end{array}$ & $\begin{array}{r}7.9 \\
8.2 \\
7.8 \\
-1.2\end{array}$ & $\begin{array}{r}9.2 \\
8.6 \\
10.6 \\
1.2\end{array}$ & $\begin{array}{r}6.2 \\
6.5 \\
6.1 \\
-2.0\end{array}$ \\
\hline 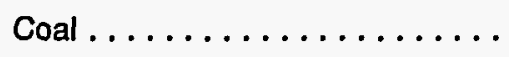 & 2.7 & 5.1 & 6.7 & 5.0 & 3.3 & 8.7 & -9.3 & 7.6 & 4.0 \\
\hline Other Energy & -0.8 & 0.5 & -2.5 & -2.3 & 2.6 & 2.8 & 1.8 & 4.1 & 4.8 \\
\hline Nonenergy $\ldots \ldots \ldots \ldots \ldots$. & 5.1 & 12.2 & 20.3 & 17.3 & 7.8 & 2.9 & 2.1 & 4.7 & 10.5 \\
\hline
\end{tabular}

Note: Rate of return measured as contribution to net income/net investment in place.

Source: Energy Information Administration, Form EIA-28. 
Figure 4. Revenues and Operating Expenses for the Chemical Segment for FRS Companies, 1981-1994.

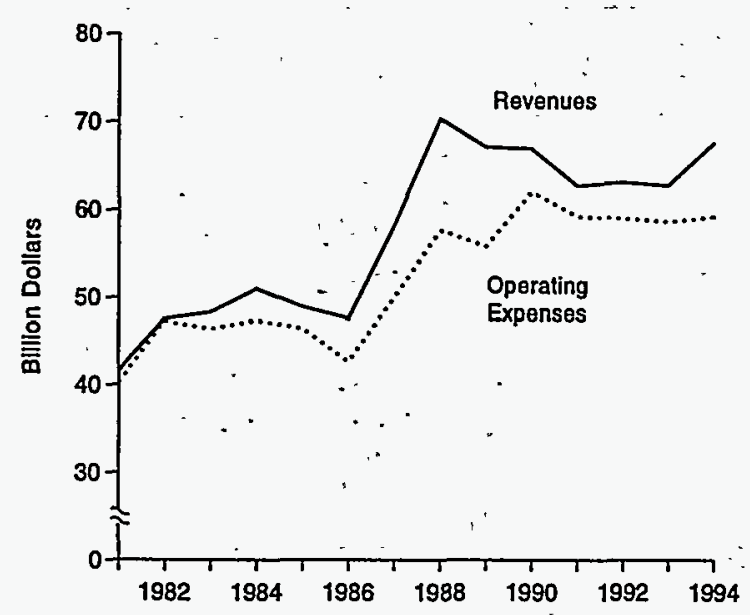

Sources: 1981-1986: Energy Information Administration, Form EIA-28. 1987-1994: Company annual reports to shareholders.

Coal production has been an area of retrenchment for some FRS companies in recent years. In 1989, 16 FRS companies reported coal production, amounting to 29 percent of total U.S. production. By the end of 1994, six FRS companies had sold their U.S. coal operations, often to foreign-based companies: BP America, Burlington Resources, Mobil, Occidental Petroleum, Shell Oil, and Sun; and DuPont transferred its Consolidation Coal unit to Consol Energy, a 50-50 joint venture between DuPont and RWE AG of Germany. The remaining FRS coal producers' share of U.S. production was 17 percent in 1994. Nevertheless, these remaining producers fared well, registering a 48-percent increase in net income (excluding unusual items) from coal. This improvement was accomplished despite a drop in U.S. coal prices in 1994. Again, cost cutting played a key role, as well as a 3-percent increase in output of continuing producers.
Another relatively small area of FRS operations that exhibited financial improvement in 1994 was the other energy line of business. Main activities include oil production from Canadian tar sands, cogeneration and natural 'gas-fired electrical generation, production of electricity from geothermal sources, and manufacture of solar power equipment. Net income from other energy was up 54 percent in 1994 and positive for the fifth consecutive year. Prior to 1990, this line of business produced operating losses for 16 years.

\section{Technology and Downsizing Reduce Costs and Improve Profitability}

Nearly every chapter of this report presents evidence that reduced costs contributed to improved financial results for the FRS companies between 1993 and 1994. The intended payoffs to cost cutting are increased cash flow and profitability. Cost-cutting efforts, to the extent they have lasting effects, should benefit a company's shareholders by raising investor expectations of future cash flow and common stock price.

Although application of advancing technology can be a route to increased efficiency and lower costs, the FRS companies have also achieved lower costs through downsizing. Reduced employment is probably the most direct evidence of downsizing. Figure 5 shows that overall employment of the FRS companies decreased steadily in the 1990's. Perhaps not surprisingly, downsizing results in lower costs. 'Figure 6 shows the positive relationship between percent changes in overall operating costs (excluding depreciation, depletion, and amortization) and percent changes in employment over the 1990-1994 period across FRS companies. With a simple correlation of 0.73 , this relationship is significant by the usual statistical conventions.

Table 4. Operating Income in Chemicals and Other Nonenergy Segments for FRS Companies, 1993-1994 (Million Dollars)

\begin{tabular}{|c|c|c|c|}
\hline Segment & 1993 & 1994 & $\begin{array}{c}\text { Percent Change } \\
1993-1994\end{array}$ \\
\hline \multicolumn{4}{|l|}{ Operating Income, Excluding Unusual Items } \\
\hline Chemicals $\ldots .$. & 4,089 & 8,609 & 110.5 \\
\hline Other Nonenergy $\ldots \ldots \ldots \ldots \ldots \ldots \ldots \ldots \ldots \ldots$ & 1,159 & 1,772 & 52.9 \\
\hline
\end{tabular}

Sources: Energy Information Administration; Form ElA-28, except for chemicals segment operating income, which was compiled from company annual reports to shareholders. 
Figure 5. Number of Employees of FRS Companies, 1981-1994

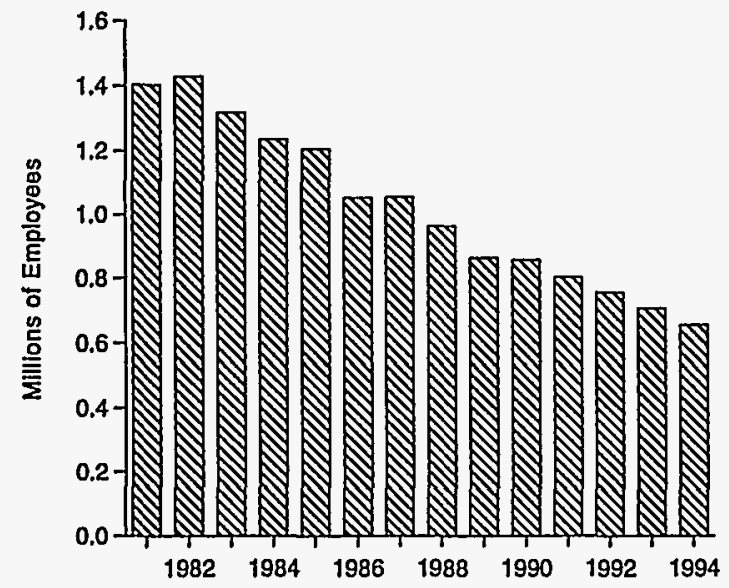

Source: Company annual reports to shareholders.

Does cost cutting translate into improved profitability and higher shareholder value for a company? If not, then the value of cost cutting appears questionable. The relationship between cost cutting and profitability was examined by a simple regression of the change in return on equity against the percent change in overall operating costs, over the 1990-1994 period, across the FRS companies. A simple correlation of -0.50 was obtained, which is significant, indicating that reducing costs tended to be associated with increased profitability.

Have the capital markets reacted as expected to the FRS companies' cost-cutting efforts? If investors take a favorable view of cost cutting, then there should be a negative relationship between changes in costs and changes in market value. That is, investors will favor the stock of companies who reduce operating costs. However, the statistical association between market value and cost cutting is weak and in the wrong direction. The simple correlation between the percent change in market value of a company's common stock, over the 1990-1994 period, and the percent change in operating costs, across FRS companies, was 0.22 , a value which is not statistically significant. This statistical result should be taken only as suggesting that cost cutting alone does not appear to be associated with changes in the FRS companies' market value. Additional influences on market value, in conjunction with cost cutting, should be considered-a task which would require a special study.
Figure 6. Downsizing Reduces Operating Costs (FRS Companies, 1990-1994)

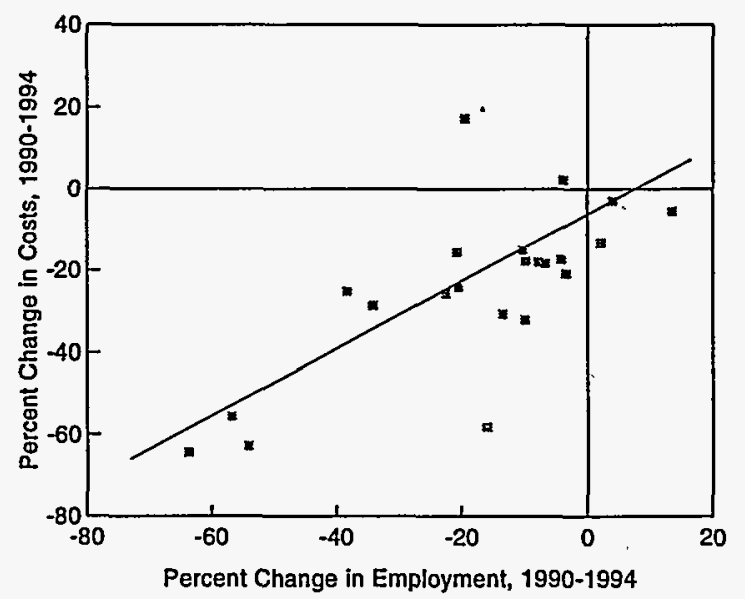

Source: Filings of Securities and Exchange Commission Form 10-K.

\section{Sources and Uses of Cash}

\section{Debt Reduced to a 10-Year Low}

Cash flow from operations ${ }^{11}$ in 1994 , at $\$ 48.3$ billion; though down 4 percent from cash flow in the prior year, was at a value typical for the years since the 1986 oil price collapse. In 1993, the FRS companies cash flow from operations reached the second highest level since 1986, exceeded only by the cash flow generated in the context of the war-induced oil price escalation in 1990. Contributions to cash flow traceable to the lines of business were up about $\$ 4$ billion (Table 5), reflecting the growth in chemical earnings in 1994. However, a variety of cash disbursements and working capital changes led to a drop in overall cash flow. For example, Chevron reported, "... increased working capital requirements, including the payment of $\$ 675$ million to the Internal Revenue Service for the settlement of substantially all open tax issues for the nine years 1979 through 1988" while DuPont noted, "... higher net income partly offset by higher cash payments for restructuring. ${ }^{12}$

Although the FRS companies' cash flow fell by $\$ 2$ billion, they continued to enhance shareholder value through increased dividends. The companies raised their dividend payout by over $\$ 1$ billion in 1994, to nearly $\$ 15$ billion (Table 6), the second-highest level ever.

\footnotetext{
"Cash is defined as currency, demand deposits, and interest-bearing assets of less than 30 days maturity. Generally, cash flow from operations is computed by adding to (subtracting from) net income those cost (revenue) items that did not actually involve an outlay (receipt) of cash. The largest of these non-cash items is the cost of depreciation, depletion, and amortization. Also, outlays (receipts) of cash that were recognized as non-cash items in previous income statements (e.g., provisions for a legal settlement taken as a charge against income in a previous year but not actually paid until the current year) are subtracted from (added to) net income in computing cash flow. Lastly, changes in working capital (excluding cash) due to operations are subtracted.

${ }^{12}$ Chevron Corporation, 1994 Annual Report, pp. 35-36, and DuPont, 1994 Annual Report, p. 31.
} 


\begin{tabular}{|c|c|c|c|}
\hline Contribution to Pretax Cash Flow ${ }^{a}$ & 1993 & 1994 & $\begin{array}{c}\text { Percent Change } \\
1993-1994\end{array}$ \\
\hline \multicolumn{4}{|l|}{ Petroleum } \\
\hline Oil and Gas Production & 36.2 & 36.8 & 1.6 \\
\hline Refining, Marketing, and Transport $\ldots \ldots \ldots \ldots \ldots \ldots$ & 17.7 & 16.0 & -9.7 \\
\hline Coal and Other Energy $\ldots \ldots \ldots \ldots \ldots \ldots \ldots \ldots$ & 0.9 & 0.9 & -3.9 \\
\hline Chemicals $\ldots \ldots \ldots \ldots \ldots \ldots \ldots \ldots \ldots \ldots \ldots$ & 8.0 & 12.3 & 54.4 \\
\hline Other Nonenergy $\ldots \ldots \ldots \ldots \ldots \ldots \ldots \ldots \ldots \ldots$ & 2.4 & 2.8 & 18.8 \\
\hline$\ldots \ldots \ldots \ldots \ldots \ldots \ldots \ldots \ldots \ldots$ & -2.7 & -1.6 & -. \\
\hline Total Contribution to Pretax Cash Flowa & 62.6 & 67.2 & 7.3 \\
\hline Current Income Taxes $\ldots \ldots \ldots \ldots \ldots \ldots \ldots \ldots \ldots$ & -10.1 & -10.0 & -- \\
\hline Other $($ Net $), \ldots \ldots \ldots \ldots \ldots \ldots \ldots \ldots \ldots \ldots \ldots$ & -2.3 & -8.9 & -- \\
\hline Cash Flow from Operations $\ldots \ldots \ldots \ldots \ldots \ldots \ldots$ & 50.2 & 48.3 & -3.8 \\
\hline
\end{tabular}

${ }^{a}$ Defined as the sum of operating income, depreciation, depletion, and amortization, and dry hole expense. Excludes unusual items.

$--=$ Not meaningful.

Note: Sum of components may not equal total due to independent rounding. Percent changes were calculated from unrounded data.

Source: Energy Information Administration, Form EIA-28.

$\therefore$

Table 6. Sources and Uses of Cash for FRS Companies, 1993-1994

(Billion Dollars)

\begin{tabular}{|c|c|c|c|}
\hline Sources and Uses of Cash & 1993 & 1994 & $\begin{array}{c}\text { Percent Change } \\
1993-1994\end{array}$ \\
\hline Main Sources of Cash & & - & \\
\hline Cash Flow from Operations $\ldots \ldots \ldots \ldots \ldots \ldots \ldots$ & 50.2 & 48.3 & -3.8 \\
\hline Proceeds from Long-term Debt $\ldots \ldots \ldots \ldots \ldots \ldots \ldots$ & 19.0 & 12.5 & -34.1 \\
\hline Proceeds from Disposals of Assets $\ldots \ldots \ldots \ldots \ldots$ & 11.8 & 6.4 & -45.2 \\
\hline Proceeds from Equity Security Offerings $\ldots \ldots \ldots \ldots$ & 2.1 & 2.6 & 21.8 \\
\hline \multicolumn{4}{|l|}{ Main Uses of Cash } \\
\hline Additions to Investment in Place $\ldots . .$. & 40.4 & 39.1 & -3.2 \\
\hline Reductions in Long-term Debt $\ldots \ldots \ldots \ldots \ldots \ldots$ & 20.9 & 13.8 & -34.1 \\
\hline Dividends to Shareholders $\ldots \ldots \ldots \ldots \ldots \ldots \ldots \ldots$ & 13.6 & 14.9 & 9.9 \\
\hline 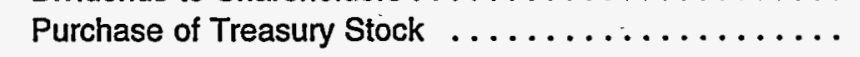 & 0.5 & 1.0 & 96.5 \\
\hline Other Investment and Financing Activities, Net ....... & -6.5 & -3.3 & -. \\
\hline Net Change in Cash and Cash Equivaients $\ldots .$. & 1.2 & -2.2 & -- \\
\hline
\end{tabular}

$--=$ Not meaningful.

Note: Sources minus Uses plus Other Investment and Financing Áctivities (Net) may not equal Net Change in Cash and

Cash Equivalents due to independent rounding. Percent changes were calculated from unrounded data.

Source: Energy Information Administration, Form ElA-28.

The FRS companies' long-running efforts to restrain their growth in debt met with notable success in 1994. Longterm debt for the companies, at $\$ 88.1$ billion in 1994, was at the lowest level in 10 years. Cash used to reduce longterm debt continued to exceed proceeds from long-term debt (Table 6). Both debt issuance and debt reduction were down sharply in 1994 due to higher interest rates. Interest rates, particularly for shorter term debt, rose to a three-year high in 1994, ${ }^{13}$ thus discouraging early debt retirement and early rollovers of debt. In 1992 and 1993, when interest

${ }^{13}$ Economic Report of the President, February 1995, p. 358. 
rates were at a 20-year low, the FRS companies made early retirements of higher interest debt, in large part through new borrowing, in order to lower their interest expenses. In 1993, the FRS companies' interest expense was down $\$ 1$ billion. In 1994, with higher interest rates, interest expense was unchanged from the prior year (Table 1).

Asset sales, another source of cash, yielded only $\$ 6.4$ billion in 1994, also a 10-year low. The largest divestiture in 1994 was Texaco's sale of its chemical operations to the Jon $M$. Huntsman Group for $\$ 850$ million. The falloff in asset sales in 1994 may be merely a respite from restructuring or may indicate that the FRS companies are largely poised for investment and long-term growth in their core areas.

The FRS core areas are mainly in petroleum (including natural gas) and chemicals. In 1994, these lines of business accounted for 90 percent of the FRS companies' capital expenditures of $\$ 39.1$ billion (Table 7). Among the core areas, U.S. oil and gas production regained its position as the number one target of overall FRS company investment, after falling behind foreign oil and gas production in recent years.

\section{Targets of Investment}

\section{Domestic Upstream Resurgence Led by Acquisitions and Natural Gas Drilling}

Oil and gas production is the primary target of overall investment of the FRS companies, accounting for the largest share of capital expenditures ${ }^{14}$ among lines of business since 1974. Subsequent to the oil price collapse of 1986, the FRS companies more than doubled their foreign upstream (exploration, development and production) expenditures while reducing their U.S. expenditures. In 1992 and 1993, foreign upstream expenditures outpaced U.S. expenditures for the first time. In 1994, this pattern was -reversed. Capital expenditures for U.S. oil and gas production totaled $\$ 10.9$ billion in 1994, up 15 percent from 1993 expenditures, but foreign expenditures of $\$ 9.8$ billion were down 15 percent (Table 7 ). Although merger and acquisition activity was again only a small part of the FRS companies' capital expenditures in 1994 (Figure 7), most acquisitions were directed toward oil and gas production (Table 8). ${ }^{15}$
The upturn in capital expenditures for U.S. oil and gas production came largely from acquisitions of proved properties (i.e., fields with producing reserves), which increased from $\$ 0.6$ billion in 1993 to $\$ 1.6$ billion in 1994 . However, this development probably more reflects the growth of U.S.-oriented companies than a shift away from foreign upstream investment. The largest acquisitions were made by Union Pacific and Burlington Resources. Energy investments of these two companies are almost entirely committed to U.S. upstream operations, in contrast to most FRS companies which are multinational and have operations that are vertically integrated from exploration through retail sales of petroleum.

The FRS companies directed most of their acquisitions to obtaining natural gas reserves. Of the proven U.S. reserves gained through purchase, 67 percent were classified as natural gas reserves in 1994, up from 47 percent in 1993 and 38 percent in 1992. This trend is consistent with the generally increased focus on U.S. natural gas as an investment target of FRS companies. Factors contributing to the attractiveness of natural gas include the movement from regulated to competitive natural gas markets, reduction in surplus U.S. production capacity, environmental considerations favoring natural gas over other fuels, and expected growth in natural gas demand. In 1994, the FRS companies increased their drilling expenditures for natural gas by 17 percent and completed 14 percent more gas wells than in 1993. Apart from natural gas drilling, the FRS companies' U.S. well completions slipped 2 percent.

Interest in natural gas development was not confined to the United States. A majority of the FRS companies have targeted Canadian natural gas for investment in recent years. Growth in capacity to deliver exports to the lower 48 States has largely driven the interest in Canadian natural gas. In 1994, the FRS companies' natural gas drilling in Canada was up 54 percent, following a fourfold increase in 1993.

Europe was the primary focus of reduced upstream capital expenditures in 1994. The FRS companies' exploration and development expenditures for Europe, mainly the North Sea, were $\$ 1$ billion lower in 1994 following a $\$ 1.3$ billion decrease in 1993. However, these large reductions were not indicative of a lessened commitment to North Sea oil and gas development. Rather, in the early 1990's, FRS

\footnotetext{
${ }^{14}$ To the extent possible, capital outlays are measured by additions to investment in place, which are defined as additions to property, plant, and equipment (PP\&E) plus additions to investment and advances. In 1994, additions to PP\&E accounted for 96 percent of capital outlays so measured. However, because additions to investments and advances were not collected for some FRS segments prior to 1981, capital outlays are sometimes measured solely by additions to PP\&E.

${ }^{15}$ Figure 7 and Table 7 show the value of property, plant and equipment, and investments and advances added to the companies' books as a result of acquisitions rather than the value of the transactions. The reported, or purchase, value of an acquisition shown in Table 8 includes effects on working capital, long-term liabilities, and other values that would not add to the acquiring company's investment base.
} 
Table 7. Additions to Investment in Place by Line of Business for. FRS Companies, 1993-1994 (Billion Dollars)

\begin{tabular}{|c|c|c|c|c|}
\hline Line of Business & 1993 & 1994 & $\begin{array}{c}\text { Percent } \\
\text { Change } \\
\text { 1993-1994 }\end{array}$ & $\begin{array}{l}\text { Percent Change } \\
\text { Excluding Mergers } \\
\text { and Acquisitions } \\
1993-1994\end{array}$ \\
\hline \multicolumn{5}{|l|}{ Petroleum } \\
\hline U.S. Petroleum & & & & ' \\
\hline Production $\ldots \ldots \ldots \ldots \ldots \ldots \ldots \ldots \ldots$ & 9.5 & 10.9 & 15.0 & 2.5 \\
\hline \multicolumn{5}{|l|}{ Refining/Marketing } \\
\hline Refining $\ldots \ldots \ldots \ldots \ldots \ldots \ldots \ldots \ldots$ & 4.5 & 4.2 & -7.0 & -10.7 \\
\hline Marketing.$\ldots \ldots \ldots \ldots \ldots \ldots \ldots \ldots \ldots$ & 1.8 & 1.8 & 2.4 & 1.6 \\
\hline 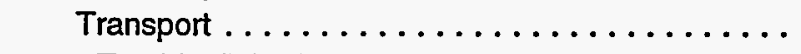 & 0.4 & 0.3 & -15.4 & -15.4 \\
\hline Total Refining/Marketing $\ldots \ldots \ldots \ldots \ldots \ldots$ & 6.7 & 6.3 & -5.0 & -7.8 \\
\hline Pipelines $\ldots \ldots \ldots \ldots \ldots \ldots \ldots \ldots \ldots \ldots$ & 1.0 & 0.8 & -14.6 & -14.6 \\
\hline Total U.S. Petroleum $\ldots . . \ldots \ldots \ldots \ldots$ & 17.1 & 18.1 & 5.6 & -2.5 \\
\hline \multicolumn{5}{|l|}{ Foreign Petroleum } \\
\hline Production $\ldots \ldots \ldots \ldots \ldots \ldots \ldots \ldots \ldots$ & 11.4 & 9.8 & -14.5 & -20.9 \\
\hline Refining/Marketing $\ldots \ldots \ldots \ldots \ldots \ldots \ldots$ & 3.3 & 3.1 & -5.7 & -5.7 \\
\hline International Marine $\ldots \ldots \ldots \ldots \ldots \ldots \ldots$ & 0.2 & 0.3 & 12.1 & 12.1 \\
\hline Total Foreign Petroleum .............. & 15.0 & 13.1 & -12.2 & -16.9 \\
\hline Total Petroleum .. & 32.1 & 31.2 & -2.7 & -9.3 \\
\hline Coal ........ & 0.2 & 0.0 & - & -- \\
\hline Other Energy $\ldots: \ldots \ldots \ldots \ldots \ldots \ldots \ldots$ & 0.4 & 0.3 & -35.2 & -35.2 \\
\hline \multicolumn{5}{|l|}{ Nonenergy } \\
\hline$\ldots \ldots \ldots \ldots \ldots \ldots$ & 4.5 & 4.0 & -11.6 & -3.6 \\
\hline$\ldots \ldots \ldots \ldots \ldots \ldots \ldots \ldots$ & 2.2 & 2.3 & 4.4 & 4.0 \\
\hline Total Nonenergy . . . . . . . . . . . . . . . . . & 6.7 & 6.3 & -6.3 & -0.9 \\
\hline Nontraceables $\ldots \ldots \ldots \ldots \ldots \ldots \ldots \ldots$ & 0.9 & 1.3 & -- & -. \\
\hline Additions to Investment in Place $^{a} \ldots \ldots \ldots \ldots \ldots$ & 40.4 & 39.1 & -3.2 & -- \\
\hline Additions Due to Mergers and Acquisitions . . . . . . . & 1.5 & 3.2 & 107.3 & -. \\
\hline Total Additions Excluding Mergers and Acquisitions ... & 38.9 & 35.9 & -7.6 & -- \\
\hline
\end{tabular}

${ }^{a}$ Measured as additions to property, plant, and equipment, plus additions to investments and advances.

$-=$ Not meaningful.

Note: Sum of components may not equal total due to independent rounding. Percent changes were calculated from unrounded data.

Source: Energy Information Administration, Form EIA-28. 
Figure 7. Additions to Investment in Place and Value of Acquisitions and Mergers for FRS Companies, 1974-1994

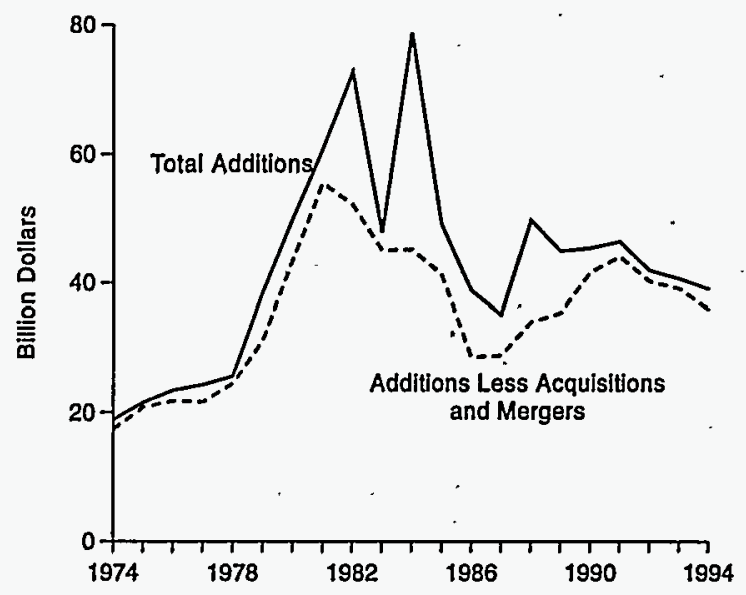

Sources; Energy Information Administration, Form ElA-28, and company filings of Securities and Exchange Commission Form 10-K. companies involved in North Sea production undertook projects to improve the rate of recovery from maturing North Sea fields as well as upgrade production facilities for reliability and safety. Having attained greater recovery rates, the North Sea producers trimmed their expenditures in recent years. The payoffs to these earlier investments are evident in the FRS companies' performance in Europe. Their combined oil and gas production grew 25 percent from 1991 to 1994, even as they sharply reduced their expenditures for oil and gas development.

\section{Apparent Stability in Refinery Outlays Obscures Dynamics}

The FRS companies, 18 of whom have refinery capacity in the United States, spent $\$ 4.2$ billion on these facilities in 1994, down slightly from the amount spent in 1993 (Table 7). Capital expenditures for U.S. refining have been at historically high levels in the 1990 's, peaking at $\$ 5.1$ billion in 1992, which was more than double the level of expenditures in 1989, even though FRS refiners reduced their basic distillation capacity by 1 million barrels per day over the period.

Table 8. Value of Mergers, Acquisitions, and Related Transactions by FRS Companies, 1994 (Million Dollars)

\begin{tabular}{|c|c|c|}
\hline Line of Business and Acquiring Company & Acquisition & $\begin{array}{l}\text { Reported Value } \\
\therefore \text { of Acquisition }\end{array}$ \\
\hline \multicolumn{3}{|l|}{ U.S. Oil and Gas Production } \\
\hline Burlington Resources $\ldots \ldots \ldots \ldots \ldots \ldots$ & Diamond Shamrock Offshore Partners, L P & 375 \\
\hline Burlington Resources $\ldots \ldots \ldots: \ldots \ldots \ldots$ & $\begin{array}{l}\text { Non-operated San Juan Basin properties from } \\
\text { Parker \& Parsley Petroleum }\end{array}$ & 44 \\
\hline Chevron ............... & $\begin{array}{l}\text { West Texas gas property acquired through } \\
\text { purchase of Pakenham, Inc. }\end{array}$ & 95 \\
\hline Occidental Petroleum .... & $\begin{array}{l}\text { Certain U.S. Gulf Coast properties from Agip } \\
\text { Petroleum, Inc. }\end{array}$ & 161 \\
\hline Union Pacific $\ldots \ldots \ldots \ldots \ldots$ & Amax Oil \& Gas, Inc. & 725 \\
\hline \multicolumn{3}{|l|}{ Foreign Oil and Gas Production } \\
\hline Chevron .............. & $\begin{array}{l}22.5 \text { percent interest in Republic of Congo field } \\
\text { from Elf Congo }\end{array}$ & 145 \\
\hline DuPont & Oryx's interest in U.K. Block 16/26 & 40 \\
\hline Occidental Petroleum & Placid Oil Company & $250^{\circ}$ \\
\hline \multicolumn{3}{|l|}{ U.S. Refining and Marketing } \\
\hline Sun Company & Philadelphia refinery from Chevron & 164 \\
\hline usx $\ldots \ldots \ldots \ldots \ldots \ldots \ldots \ldots \ldots \ldots \ldots \ldots$ & $\begin{array}{l}\text { Martin Oil Co., including } 89 \text { gasoline outlets and } \\
\text { convenience stores }\end{array}$ & 69 \\
\hline
\end{tabular}

Sources: Company annual reports to shareholders, Oil and Gas Investor (September 1994 and April 1995), and various issues of The Wall Street Journal. 
Environmental requirements were responsible for about half the growth in expenditures. The Clean Air Act Amendments of 1990 and earlier environmental legislation presented U.S. refiners with a series of requirements to be met through the year 2000. Upgrading of retained facilities to produce lighter products and utilize lower quality inputs accounted for the balance of U.S. refining expenditures.

Although 1994 capital expenditures for U.S. refining were little changed from expenditures in 1993, a number of restructurings were undertaken in 1994. Chevron sold its Philadelphia refinery to Sun (also an FRS company) and carried on negotiations to sell its Port Arthur, Texas, refinery to Canadian-based Horsham Corp., a deal which was completed in early 1995 . Both of these refineries were initially acquired by Chevron in its merger with Gulf Oil in 1984. Amerada Hess mothballed its Purvis, Mississippi, refinery in 1994 as did Coastal with its El Dorado and Augusta refineries in Kansas. Kerr-McGee announced in January 1995 that it was selling its U.S. downstream assets. These moves were part of continuing adjustments of the U.S. refining industry to the rigorous business conditions of the 1990's. Downstream restructuring in part reflects attempts to achieve lower operating costs in order to offset higher costs stemming from environmental requirements. Also, the outlook for some formerly economic refineries and the areas they serve cannot justify added investments for upgrading and environmental compliance.

Domestic gasoline marketing has also been an area of consolidation and geographic realignment. For example, BP America sold its California marketing network to Tosco, a non-FRS refiner, and the FRS companies, overall, continued to reduce their retail gasoline outlets, by over 3,000 , from 1993 to 1994. Consolidation of marketing operations paid off in terms of lower marketing costs in 1994 (Chapter 4). Despite the reduced number of gasoline outlets, the FRS companies' capital expenditures for marketing, at \$1.8 billion in 1994, were little changed from expenditures in recent years. This finding suggests that expenditures have been directed toward upgrading and modernization of retained outlets.

Capital expenditures for foreign refining and marketing, at $\$ 3.1$ billion in 1994, were also little changed from those in 1993. However, in contrast to U.S. downstream operations, foreign downstream has been largely an area of growth in the 1990's. For example, FRS foreign distillation capacity grew by 8 percent during the 1990's. The bulk of FRS downstream activity abroad is accounted for by Chevron, DuPont, Exxon, Mobil, and Texaco. All of these companies reported ongoing expansions in the Pacific Rim and Asia. Other areas of growth variously noted in company reports included Latin America, Eastern Europe, and parts of Western Europe. Amoco reported that it was managing the expansion of a major refinery outside Moscow.

With the doubling of profits from the FRS companies' chemical operations (Table 4), 1994 might be described as a banner year for this line of business. Although profits were up, capital expenditures for chemicals continued to decline. The FRS companies have steadily reduced capital expenditures for their chemical businesses, from the peak value of $\$ 7.8$ billion in 1990 to $\$ 4.0$ billion in 1994 . Worldwide excess capacity in chemical manufacturing contributed to a plunge in earnings until the rebound in 1994. The sources of improved financial conditions in 1994, which included temporary outages in capacity and low product inventories, may have been viewed as too shortlived to justify significant capacity additions.

Capital expenditures for diversified businesses were $\$ 2.3$ billion in 1994. Fourteen of the FRS companies incurred expenditures for this line of business, with a majority of this group reporting higher spending in 1994. Among the largest increases in expenditures disclosed were: Exxon's \$156 million in added expenditures associated with increased capacity in their Hong Kong power generation operations, Mobil's expenditures for activities encompassing real estate and phosphate production which were up $\$ 51$ million, and USX's steel business with $\$ 50$ million in added capital expenditures. ${ }^{16}$

\section{Taxes in 1994}

\section{Current Income Taxes Trend Downward}

Worldwide income taxes for FRS companies were 36 percent of pretax income in 1994, nearly unchanged from the rate in 1993. (Figure 8A), and virtually identical to the effective tax rate of other large U.S. corporations as represented by the S\&P 400 . The convergence of effective tax rates between these two groups in part reflects the workings of the Tax Reform Act of 1986, which was intended to "level the playing field" by reducing the differences in Federal tax treatment across industries.

Another similarity between the FRS companies and the S\&P 400 group was the downward trend in current income taxes. Current income taxes are those taxes deemed

\footnotetext{
${ }^{16}$ Exxon Corporation, Financial and Operating Review 1994, p.69; Mobil Corporation, 1994 Mobil Fact Book, p. 20; USX, Securities and Exchange Commission Form 10-K, p. S-25.
} 

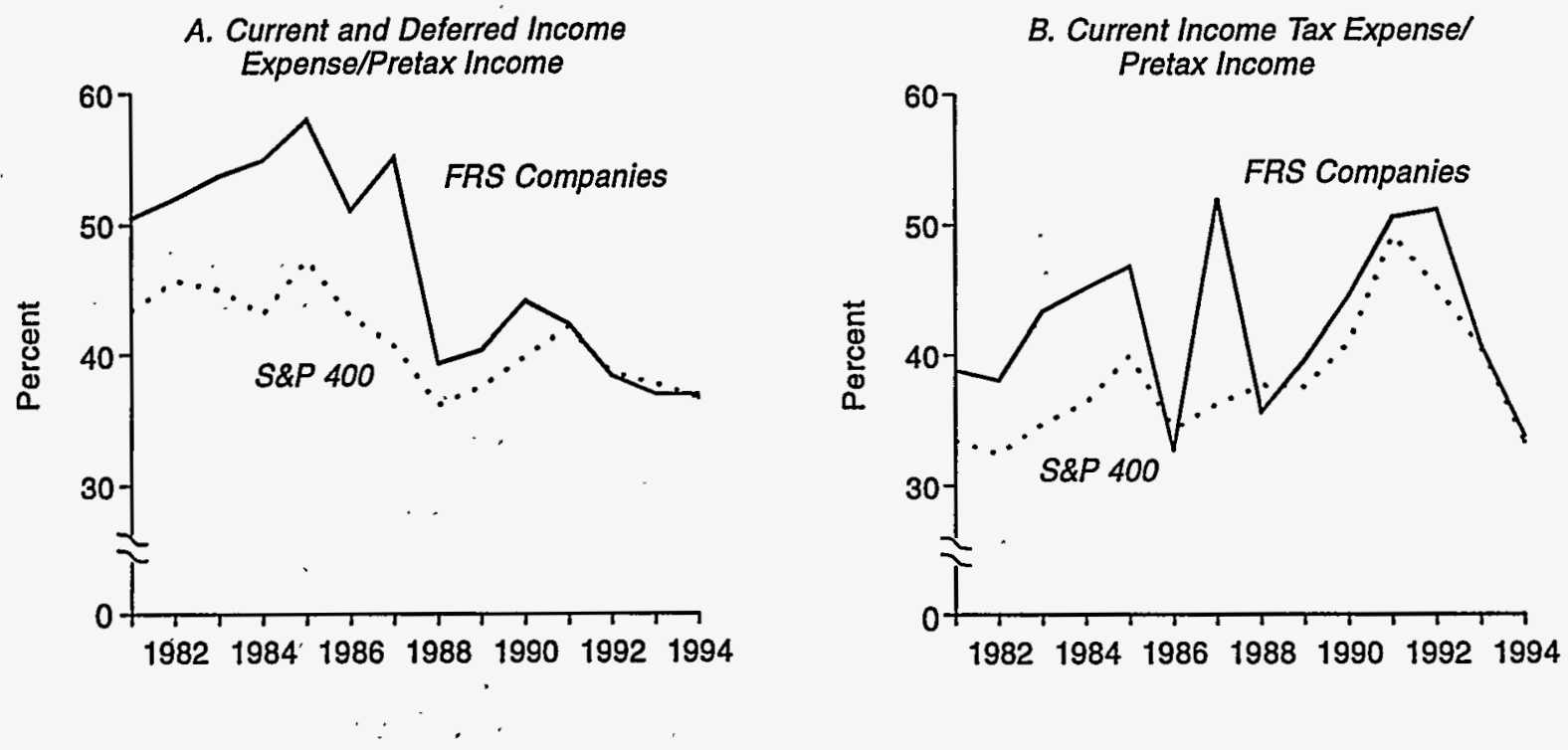

Sources: FRS Companies: Energy Information Administration, Form ElA-28. S\&P 400: Standard \& Poor's Compustat Senvices, Inc.

payable in the reporting year. ${ }^{17}$ Figure $8 \mathrm{~B}$ shows that current taxes, relative to pretax income, have been declining sharply in recent years. This decline was disproportionately concentrated in U.S. Federal taxes. ${ }^{18}$ In 1994, current Federal income taxes for the FRS companies declined 18 percent, or by $\$ 0.5$ billion, even though pretax income was up 19 percent between 1993 and 1994 (Table 9). The reasons for the trend in current Federal taxes are not altogether clear. However, the Tax Reform Act of 1986 may have played an important role, in that it phased in strengthened provisions of the Alternative Minimum Tax
$(A M T)^{19}$ from the late 1980 's to the early 1990 's. Nearly all FRS companies have reported an increase in current taxes in at least one year due to the AMT. The impact was greatest from 1990 to 1992, when FRS companies paid an additional $\$ 1.5$ billion as a result of the AMT. ${ }^{20}$ By the 1993-1994 time period, however, the AMT was fully phased in. Rather than experiencing a large increase in current income taxes, FRS companies had a \$158-million AMT tax credit in 1993, and only a small increase ( $\$ 30$ million) in current taxes attributable to the AMT in 1994 (Appendix B, Table B19).

\footnotetext{
${ }^{17}$ For financial reporting purposes, income taxes are categorized as current or deferred. Current taxes are deemed payable in the reporting year. Deferred taxes are differences between income tax expense accrued under Generally Accepted Accounting Principles for financial reporting purposes and income taxes currently payable in the reporting period. They originate from a variety of sources and are important to the financial operations of energy companies, as well as to industry in general. Basically, deferred taxes originate because of timing differences in reporting revenue and expense for financial reporting and tax reporting. Financial reporting attempts to match items of income and expense in the periods in which they occur. Tax reporting may permit different timing for recognizing revenues and deducting expenses. For example, faster writeoffs of depreciable properties are permitted under tax laws while they may not be acceptable under financial accounting principles. Accelerated writeoffs result in lower taxable income and thus lower tax liability in the year taken. In future periods, however, taxable income and income taxes payable may be higher than pretax income for financial reporting purposes because the timing differences between tax and financial reporting are reversed.

${ }^{18}$ In the 1990's, worldwide current taxes peaked at $\$ 16.7$ billion in 1990 (Table B19 in Appendix B), reflecting the increase in taxable income in the context of oil price escalations induced by Iraq's invasion of Kuwait. In 1990, U.S. Federal income taxes accounted for about a third of the FRS companies' worldwide current taxes. In 1994, worldwide current taxes totaled $\$ 10.0$ billion, with U.S. Federal taxes accounting for 53 percent of the decline.

${ }^{19}$ Under Federal income tax laws, a corporation pays the greater of (1) taxes computed from the regular corporate income tax system or (2) taxes computed from the AMT.

${ }^{20}$ Table B19 in Appendix B.
} 
Table 9. Composition of Income Tax Expense for FRS Companies, 1993-1994 (Billion Dollars)

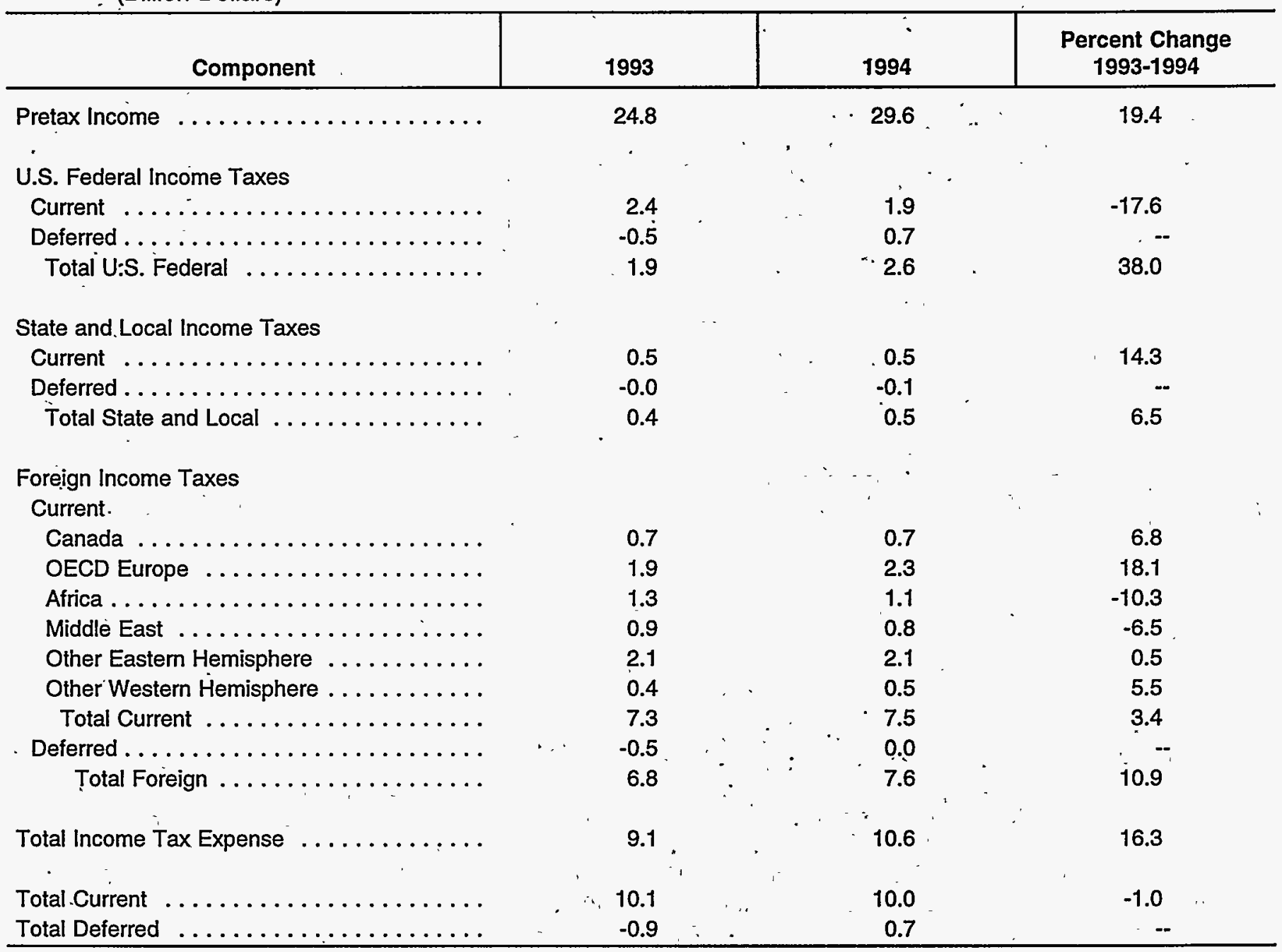

$--=$ Not meaningful.

Note: Sum of components may not equal total due to independent rounding. The Former Soviet Union and Eastern Europe are included in OECD Europe to avoid disclosure.

Source: Energy Information Administration, Form EIA-28.

\section{Taxes Decrease in U.S. Oil and Gas ,}

Among lines of business, U.S. oil and gas production showed a decline of $\$ 0.9$ billion in income taxes between 1993 and 1994 (Table 10). Direct taxes levied by the States on oil and gas production revenues also declined in 1994 (see the box entitled, "Severance Taxes" on page 18). The drop in income tax expense reflected the influence of a variety of factors, including Section 29 and related tax credits and the effects of the corporate tax rate increase in
1993. Particularly important was the increased use of "Section 29" tax credits, which apply to the production of certain alternative (or nonconventional) fuels. ${ }^{21}$ One of the most important regions for coalbed methane production (qualifying for Section 29 credits) is the San Juan basin in northwest New Mexico and southwest Colorado. In this region, Amoco, Burlington Resources, and Phillips Petroleum have been aggressively producing gas. ${ }^{22}$ DuPont, Enron, and Mobil are similarly active in south Texas. ${ }^{23}$ Other popular coalbed methane areas are in Oklahoma,

\footnotetext{
21"Section 29," or nonconventional, fuels generally include oil produced from shale and tar sands; gas produced from geopressurized brine, Devonian shale, coal seams, tight formations, or biomass; and liquid, gaseous, or solid synthetic fuels produced from coal.

22"Tight Sands Gas Gains Attention Among San Juan Basin Operators," Oil \& Gas.Journal (January 23, 1995$)$, p. 12.

23"New Seismic, Drilling/Completion Dope Spurs S. Texas Boom," Improved Recovery Week (August 15, 1994).
} 
Table 10. Income Tax Expense, Pretax Income, and Effective Tax Rates by Line of Business for FRS Companies, 1993-1994

\begin{tabular}{|c|c|c|c|c|c|c|}
\hline \multirow[b]{2}{*}{ Line of Business } & \multicolumn{3}{|c|}{1993} & \multicolumn{3}{|c|}{1994} \\
\hline & $\begin{array}{l}\text { Pretax } \\
\text { Income }\end{array}$ & $\begin{array}{c}\text { Income } \\
\text { Tax } \\
\text { Expense }\end{array}$ & $\begin{array}{l}\text { Effective } \\
\text { Tax Rate }\end{array}$ & $\begin{array}{l}\text { Pretax } \\
\text { Income }\end{array}$ & $\begin{array}{l}\text { Income } \\
\text { Tax } \\
\text { Expense }\end{array}$ & $\begin{array}{l}\text { Effective } \\
\text { Tax Rate }\end{array}$ \\
\hline & \multicolumn{2}{|c|}{ billion dollars } & percent & \multicolumn{2}{|c|}{ billion dollars } & percent \\
\hline Petroleum & & & & & & \\
\hline U.S. Petroleum & 12.7 & 4.4 & 34.6 & 12.5 & 3.7 & 29.4 \\
\hline Oil and Gas Production .......... & 7.2 & 2.2 & 30.7 & 6.5 & 1.3 & 20.2 \\
\hline Refining/Marketing/Pipelines . ..... & 5.5 & 2.2 & 39.7 & 6.1 & 2.4 & 39.2 \\
\hline Foreign Petroleum & 15.1 & 6.7 & 44.4 & 14.2 & 7.1 & 49.6 \\
\hline Oil and Gas Production .... & 10.3 & 5.1 & 49.5 & 10.2 & 5.7 & 55.5 \\
\hline Refining/Marketing/Marine . . . . . . . & 4.8 & 1.6 & 33.6 & 4.0 & 1.4 & 34.5 \\
\hline Coal ...... & 0.2 & 0.1 & 28.1 & 0.2 & 0.0 & 2.3 \\
\hline Other Energy $\ldots \ldots \ldots \ldots \ldots \ldots \ldots$ & 0.2 & 0.1 & 46.5 & 0.3 & 0.2 & 52.1 \\
\hline Nonenergy $\ldots \ldots \ldots \ldots \ldots \ldots$ & 4.3 & 1.3 & 31.2 & 9.3 & 2.7 & 28.7 \\
\hline Total Allocated ... & 32.6 & 12.6 & 38.7 & 36.6 & 13.6 & 37.1 \\
\hline Nontraceables and Eliminations ....... & -7.8 & -3.5 & - & -7.0 & -3.0 & -- \\
\hline Total Consolidated & 24.8 & 9.1 & 36.9 & 29.6 & 10.6 & 35.9 \\
\hline
\end{tabular}

$--=$ Not meaningful.

Note: Sum of components may not equal total due to independent rounding. Effective tax rates are calculated from unrounded data.

Source: Energy Information Administration, Form EIA-28.

West Virginia, Pennsylvania, and Alabama. To a lesser extent, FRS companies also benefitted from Enhanced Oil Recovery tax credits. ${ }^{24}$ Based on information filed with submissions of Form EIA-28, Section 29 and Enhanced Oil Recovery tax credits reduced the FRS companies' income taxes in U.S. oil and gas production by $\$ 534$ million in 1993 and $\$ 636$ million in 1994.

Also affecting income tax expense was the Omnibus Budget Reconciliation Act of 1993, which increased the
Federal corporate income tax rate from 34 percent to 35 percent ${ }^{25}$ Accounting standards require that in the event of a change in the corporate tax rate, deferred tax assets and liabilities must be recomputed at the new tax rate. Based on information in company annual reports and filings of Form EIA-28, the tax rate increase caused a oneyear spike of $\$ 273$ million in added income tax expense in U.S. oil and gas production in 1993. However, since the Federal corporate income tax rate remained constant, no such effect occurred in 1994.

\footnotetext{
${ }^{24}$ Enhanced Oil Recovery projects involve the use of tertiary methods (primarily injection of liquids or gases) in reservoirs where oil no longer can be brought up by primary or secondary (water pumping) oil recovery methods.

${ }^{25}$ Omnibus Reconciliation Act of 1993, Public Law No. 103-66, 107 Stat. 31.
} 


\section{Severance Taxes}

In the United States, State govemments often tax a portion of the value of natural resources extracted, or "severed." The States generally levy energy severance taxes as a percent of the value of the resources removed or sold (an ad valorem tax) but sometimes tax the volume of the resource removed (a per-unit tax). Royalty payments, income taxes, and property taxes related to energy production also contribute to State receipts from energy production. A recent Energy Information Administration report, State Energy Severance Taxes; 1985-1993, provides an analysis of severance taxes on oil and gas, and coal, for the States as a group and for the leading energy-producing States. After Fiscal Year 1987, low energy prices and the general lack of growth in energy production resulted in a flattening of severance tax collections. As energy severance tax receipts have declined, most of the energy-producing States have come to rely less on severance taxes as a source of revenue. In 1985, for example, the States as a group collected $\$ 7.0$ billion in energy severance taxes (oil, gas, and coal), 3.3 percent of all State tax receipts. By 1993, however, energy severance tax collections fell to $\$ 4.6$ billion, 1.3 percent of all State tax receipts. For oil and gas severance taxes, collections on production under State jurisdiction decreased 38 percent from 1985 to 1993 , from $\$ 6.4$ billion

\section{Figure 9. Reliance on Oil and Gas Sèverance Taxes, Selected States}

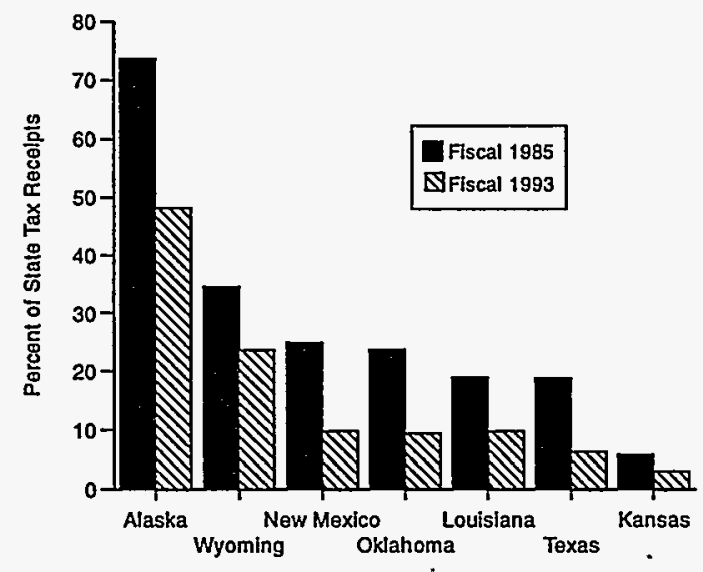

Source: Energy Information Administration, State Energy Severance Taxes 1985-1993, DOE/EIA-TR/0599 (Washington, DC, September 1995). to $\$ 4.0$ billion. Figure 9 shows how States' reliance on oil and gas severance taxes (as a percentage of total State tax receipts) varies from State to State, with Alaska the most dependent of the top eight oil and gas producing States. Note that: Califomia, although one of the top eight oiland gas-producing states, is not shown in the figure, as Califomia has only negligible oil and gas severance tax receipts.

The FRS companies, as major domestic producers of oil and gas, generally paid more than 50 percent of all State oil and gas severance taxes from 1985 to 1993 . In 1990, when oil prices escalated, the FRS companies' share of oil and gas severance taxes reached nearly 70 percent (Figure 10). Note that the FRS companies' share of total U.S. oil and gas wellhead revenues are closely correlated to the FRS companies' share of severance taxes. This correlation indicates that the variability in the FRS companies' share in total oil and gas severance taxes is the result of volatility in wellhead revenues, rather than severance tax policy changes, as the rates at which severance taxes are typically levied vary little over time. In 1994, the FRS companies' payments for oil and gas production taxes fell 10 percent, to $\$ 1.7$ billion (Table B20 in Appendix B).

Figure 10. FRS Companies' Shares of U.S. Oil and Gas Severance Taxes and Wellhead Revenues

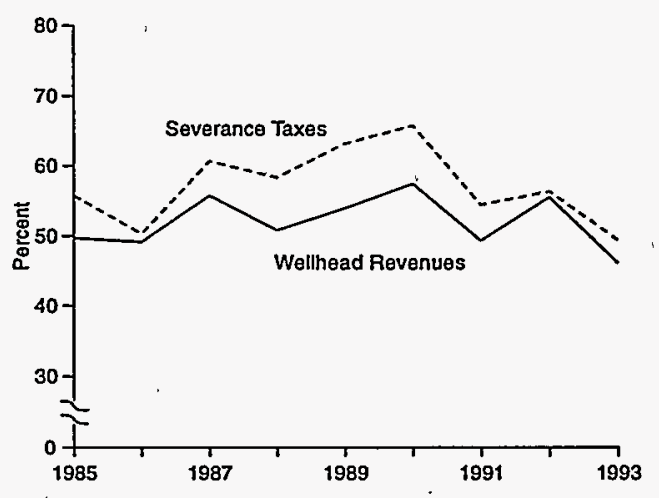

Sources: FRS Companies: Energy Information Administration, Form ElA-28. U.S. Totals: Energy Information Administration, State Energy Severance Taxes 1985-1993, DOE/EIA-TR/0599 (Washington, DC, September 1995).

aEnergy Information Administration, State Energy Severance Taxes, 1985-1993, DOE/EIA-TR/0599 (Washington, DC, September 1995). Also available on ElA's World Wide Web Site: http:/hww.eia.doe.gov. 


\section{Oil and Gas Exploration, Development, and Production}

\section{Financial Results}

\section{Upstream Income Improves Despite Lower Prices}

The FRS companies managed to realize modest increases in net income (excluding the effects of unusual items) from both U.S. and foreign oil and gas production in 1994 (Table 11). They achieved an improvement in financial results despite market developments that put downward pressure on oil and gas prices. However, the sources of financial improvement differed somewhat between the United States and abroad. Generally, foreign operations benefitted from growth in oil and gas production, reflecting the FRS companies' nearly decade-long upswing in foreign exploration and development activity. Domestic results tended to reflect consolidation and cost cutting and, in 1994, lower taxes.

Although FRS companies have consolidated their U.S. upstream operations, natural gas has been a focus of growth in recent years. Opportunities afforded by deregulation of natural gas markets and heightened prospects for growth in natural gas demand underlay this development. In 1994, when U.S. consumption of natural gas increased 2 percent from consumption in 1993, the FRS companies' natural gas production increased 5 percent and their natural gas sales increased 10 percent from comparable values in 1993 (Table 12). ${ }^{26}$ Total natural gas sales exceeded production by 35 percent in 1994, as a number of FRS companies became more interested in marketing and reselling natural gas, in addition to producing more gas.

Although U.S. natural gas demand was up 2 percent in 1994, total natural gas production and imports increased by 4 percent, resulting in a 10-percent decline in U.S. natural gas prices. Lower prices for gas, along with lower crude oil prices and production, resulted in a decline in revenues from U.S. oil and gas production of nearly $\$ 3$ billion in 1994 (Table 11). Yet, net income (excluding unusual items) was up slightly. Cost cutting and lower taxes underlay the improvement in bottomline results.

Cost cutting within U.S. oil and gas operations has been an ongoing process for the FRS companies. For example, beginning at about the time of the 1986 oil price collapse, the FRS companies have steadily reduced their costs of extracting (or "lifting") U.S. oil and gas (Figure 11). Cost reductions were accomplished largely by divestitures of high-cost fields and, more recently, through consolidations and application of technological improvements, including horizontal drilling. In 1994, the FRS companies again reduced U.S. lifting costs, by nearly $\$ 1$ billion.

Taxes on income from the FRS companies' U.S. oil and gas production operations were also nearly $\$ 1$ billion lower than in 1994 (Table 11). As noted in the taxation section of Chapter 2, this reduction was due mainly to lower pretax income and a one-time accounting change, plus an assortment of tax offsets. Tax credits for production of nonconventional fuels (largely coalbed methane) were up by $\$ 102$ million. Non-income taxes levied directly on the sales of oil and gas production were lower as well. Since these latter taxes are generally based on the value of production (see the box entitled "Severance Taxes," Chapter 2), their decline reflected the course of U.S. oil and gas prices between 1993 and 1994.

The FRS companies' foreign oil and gas production operations posted a slight increase in revenues, unlike U.S. oil and gas operations. Although oil prices realized abroad declined by over a dollar per barrel, strong Canadian natural gas prices and foreign production increases of 7 percent for oil and 5 percent for gas more than offset lower oil prices (Table 12). European operations accounted for most of the gain in oil production (see the box entitled "North Sea: Early Infrastructure Continues to Pay Off" on page 23) while production of natural gas from fields in the Other Eastern Hemisphere as well as in Europe was up compared with production in 1993. Also, in contrast to U.S. oil and gas

\footnotetext{
${ }^{26}$ Energy Information Administration, Monthly Energy Review, September 1995, DOE/EIA-0035(95/9) (Washington, DC, September 1995), p. 74.
} 
Table 11. Income Components and Financial Ratios in Oil and Gas Production for FRS Companies, 1993-1994

(Billion Dollars)

\begin{tabular}{|c|c|c|c|c|}
\hline \multirow[b]{2}{*}{ Components of Income and Financial Ratios } & \multicolumn{2}{|c|}{ United States } & \multicolumn{2}{|c|}{ Foreign } \\
\hline & 1993 & 1994 & 1993 & 1994 \\
\hline \multicolumn{5}{|l|}{ Oil and Gas Revenues } \\
\hline 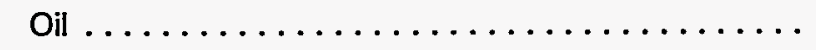 & 25.7 & 23.5 & NA & NA \\
\hline 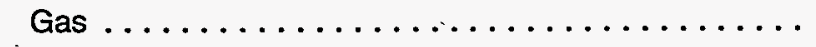 & 20.2 & 19.8 & NA & NA \\
\hline Total Revenues $\ldots \ldots \ldots \ldots \ldots \ldots \ldots$ & 46.0 & 43.2 & 33.8 & 34.2 \\
\hline \multicolumn{5}{|l|}{ Expenses } \\
\hline DD\&A & 11.5 & 11.2 & 6.3 & 7.0 \\
\hline Lifting Costs $\ldots \ldots \ldots \ldots \ldots \ldots \ldots \ldots \ldots$ & 13.7 & 12.8 & 9.3 & 9.3 \\
\hline Exploration Expenses $\ldots \ldots \ldots \ldots \ldots \ldots \ldots$ & 1.4 & 1.7 & 2.5 & 2.9 \\
\hline General and Administrative Expenses $\ldots \ldots \ldots \ldots$ & 1.6 & 1.3 & 0.9 & 0.9 \\
\hline$\ldots \ldots \ldots \ldots \ldots \ldots \ldots$ & 7.5 & 8.6 & NA & NA \\
\hline Other Costs (Revenues) ${ }^{\mathrm{a}}$ & 2.4 & 0.0 & 5.7 & 4.8 \\
\hline Total Operating Expenses ${ }^{a} \ldots \ldots \ldots \ldots \ldots$ & 38.2 & 35.6 & 24.8 & 24.9 \\
\hline Operating Income ${ }^{a}$ & 7.8 & 7.6 & 9.1 & 9.3 \\
\hline Other Income (Expense) $)^{a, b}$ & -0.1 & -0.5 & 0.3 & 0.9 \\
\hline Income Tax Expense $\ldots \ldots \ldots \ldots \ldots \ldots \ldots$ & 2.2 & 1.3 & 5.1 & 5.7 \\
\hline Net Income, Excluding Unusual Items $\ldots \ldots \ldots \ldots$ & 5.5 & 5.8 & 4.3 & 4.5 \\
\hline Unusual Items $\ldots \ldots \ldots \ldots \ldots \ldots \ldots \ldots \ldots \ldots$ & -0.7 & -1.0 & 0.9 & -0.5 \\
\hline Net Income $\ldots \ldots \ldots \ldots \ldots \ldots \ldots \ldots \ldots \ldots \ldots$ & 4.8 & 4.8 & 5.2 & 4.0 \\
\hline \multicolumn{5}{|l|}{ Unit Values (Dollarș Per Barrel of Production COE) ${ }^{c}$} \\
\hline Direct Lifting Costs (Excluding Taxes) . ...... & 3.93 & 3.68 & 3.69 & 3.61 \\
\hline Production Taxes,$\ldots \ldots \ldots \ldots \ldots \ldots \ldots \ldots$ & 0.64 & 0.57 & 0.86 & 0.67 \\
\hline \multicolumn{5}{|l|}{ Ratios (Percent) } \\
\hline Rate of Return ${ }^{d}$ & 5.3 & 5.5 & 8.6 & 6.5 \\
\hline Effective Tax Rate ${ }^{\theta}$ & 30.7 & 20.2 & 49.5 & 55.5 \\
\hline
\end{tabular}

${ }^{\mathrm{a} E x c l u d e s}$ unusual items.

bEarnings of unconsolidated affiliates, gain (loss) on disposition of assets, excluding unusual items not already excluded from operating income.

${ }^{\circ} \mathrm{COE}=$ Crude oil equivalent. Dry natural gas was converted at 0.178 barrels of oil per thousand cubic feet.

${ }^{d}$ Net income divided by net investment in place (Net investment in place = net property, plant, and equipment plus investments and advances).

Income tax expense divided by pretax income.

NA $=$ Not available.

DD\&A = Depreciation, depletion, and amortization costs.

Note: Sum of components may not equal total due to independent rounding.

Source: Energy Information Administration, Form ElA-28.

production operations, foreign operating costs hardly changed.Lower unit lifting costs (Figure 11) were offset by increased exploration expenses and capital recovery costs (i.e., depreciation, depletion, and amortization) (Table 11). In -further contrast, income tax expense in foreign production increased, by over 10 percent from 1993. In 1994, the profitability of U.S. and foreign upstream operations continued to converge, albeit at relatively low rates of return (Figure 12). 
Domestic Oil and Gas Production ${ }^{\mathrm{a}}$

Crude Oil and NGL (Million Barrels) ................

Dry Natural Gas (Billion Cubic Feet) $\ldots \ldots \ldots \ldots \ldots \ldots \ldots$

Total (Million Barrels, COE) $)^{\mathbf{b}} \ldots \ldots \ldots \ldots \ldots \ldots \ldots$

$1,632.5$
$7,651.1$
$2,994.4$

$1,593.8$

$-2.4$

4.5

Domestic Oil and Gas Sales Volumes

Crude Oil and NGL (Million Barrels) . . . . . . . . . . . . .

Dry Natural Gas (Billion Cubic Feet) $\ldots \ldots \ldots \ldots \ldots \ldots \ldots$

Total (Million Barrels, COE) ${ }^{b} \ldots \ldots \ldots \ldots \ldots \ldots \ldots \ldots$

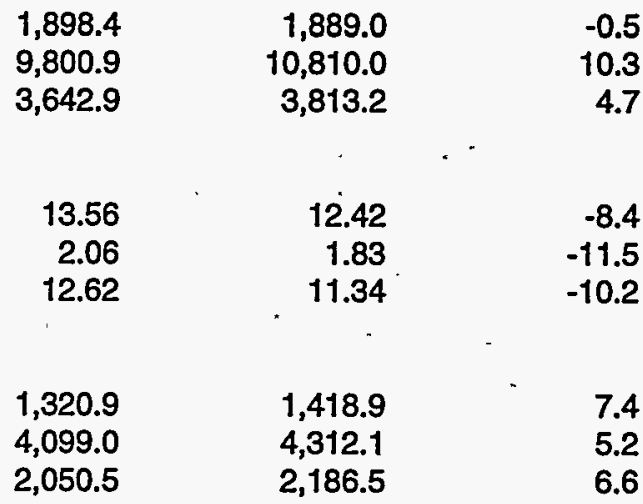

Domestic Production Segment Per. Unit Sales Values

Crude Oil and NGL (Dollars Per Barrel) . . . . . . . . . . .

Dry Natural Gas (Dollars Per Thousand Cubic Feet) . . . . . . .

Composite (Dollars Per Barrel COE) ${ }^{\mathrm{b}}$

b....................

Foreign Oil and Gas Production ${ }^{a}$

Crude Oil and NGL (Million Barrels) . . . . . . . . . . . .

Dry Natural Gas (Billion Cubic Feet) $\ldots \ldots \ldots \ldots \ldots \ldots \ldots$

Total (Million Barrels COE) ${ }^{b}$

.....................

$2,050.5$

$2,186.5$

5.2

Foreign Production Segment Per Unit Sales Values

Crude Oil and NGL (Dollars Per Barrel) . . . . . . . . . . .

Dry Natural Gas (Dollars Per Thousand Cubic Feet) . . . . . . .

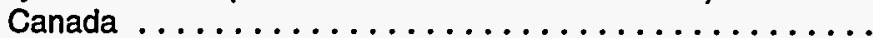

OECD Europe $\ldots \ldots \ldots \ldots \ldots \ldots \ldots \ldots \ldots \ldots$

Other Foreign $\ldots \ldots \ldots \ldots \ldots \ldots \ldots \ldots \ldots \ldots$

$\begin{array}{rrr}15.97 & 14.78 & -7.5 \\ 1.92 & 1.91 & -0.5 \\ 1.35 & 1.37 & 1.5 \\ 2.46 & 2.44 & -0.8 \\ 1.73 & 1.65 & -4.6\end{array}$

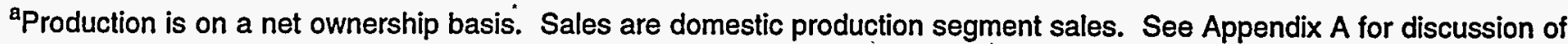
FRS reporting conventions.

${ }^{\mathrm{b}} \mathrm{COE}=$ Crude oil equivalent. Dry natural gas was converted at 0.178 barrels of crude oil per thousand cubic feet.

Sources: Energy Information Administration, Form EIA-28. Foreign production segment per unit sales values were compiled from information in FRS companies' filings of Securities and Exchange Commission Form 10-K, annual reports to shareholders, and supplements to annual reports. Figure 11. Direct Oil and Gas Lifting Costs
for FRS Companies, 1981-1994

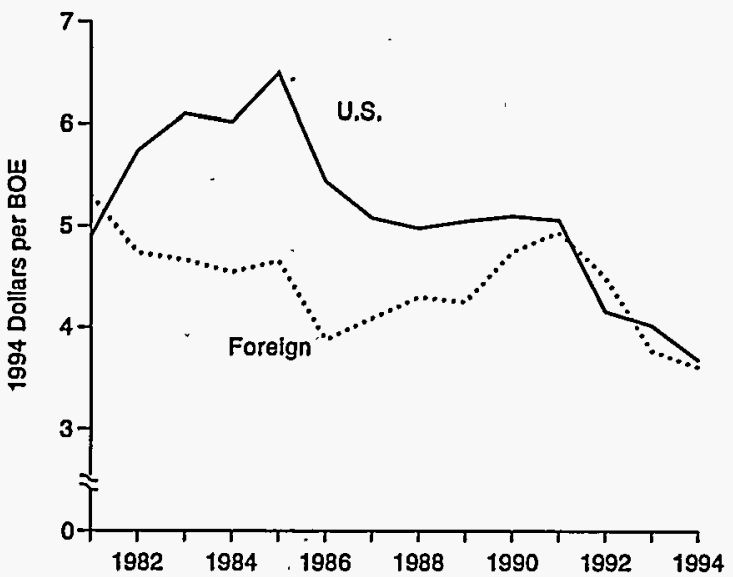

BOE = Barrels of crude oil equivalent.

Source: Energy Information Administration, Form EIA-28.
Figure 12. Rates of Return in U.S. and Foreign Oil and Gas Production for FRS Companies, 1981-1994

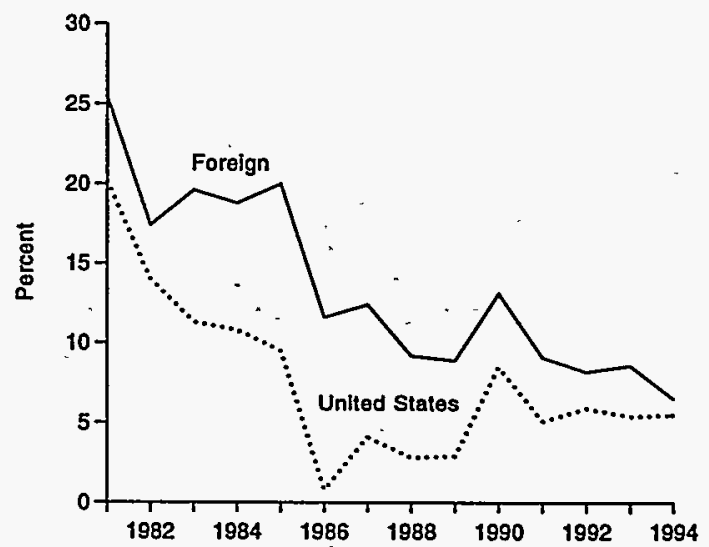

Source: Energy Information Administration, Form ElA-28. 


\section{Investment Strategies and Results}

\section{Upstream Strategies Reflect Cost-Conscious Growth}

The FRS companies increased their worldwide exploration and development expenditures by 4 percent in 1994 , to $\$ 24$ billion (Table 13). The FRS companies allocate about 50 percent of invested cash to oil and gas exploration and development projects. Since these projects generate proportionately more internal cash. (see Table 5 and Table 7 in Chapter 2), they are net cash generators and provide funds for other company operations. The anxious retrenchment in upstream operations during the late 1980's and early 1990's, if continued, would have eventually undermined corporate cash flow. To maintain cash flow and at the same time cope with lower oil prices, the FRS companies' investment strategies have broadened. The companies report evaluating projects with a view to long-term prospects and synergies with ongoing operations, not simply cost. As Chevron put it, "[T]he period of major restructuring is over... [we are] looking to growth opportunities, but also still have cost cutting goals in place. ${ }^{27}$ Phillips aims for growth in both reserves and asset values, while keeping development costs low. ${ }^{28}$ Amerada Hess reports modest capital spending, built on past successes, in addition to cost cutting. ${ }^{29}$ Unocal announced that it is "organized and motivated for growth" and intends to build on its strengths as a low-cost oil and gas producer, a major player in the Far East, and a world leader in geothermal energy development. ${ }^{\prime 30}$

One focus of cost-conscious investment is the offshore United States, mainly the Gulf of Mexico. In 1994, FRS companies increased offshore exploration and development spending (including proved acreage) by 29 percent, from $\$ 3.7$ to $\$ 4.8$ billion (Table 13). Increased spending was widespread across the FRS companies. Shell continued to expand its large offshore role, citing its "highly-focused exploration and development program in the Gulf of Mexico." ${ }^{\prime 31}$ Among the relatively smaller companies, Burlington Resources acquired Diamond Shamrock Offshore Partners Limited Partnership, Union Pacific bought Amax's oil and gas unit, and Occidental acquired Gulf of Mexico reserves by purchasing Placid Oil Company and interests from Agip Petroleum. ${ }^{32}$

Table 13. Exploration and Development Expenditures for FRS Companies by Region, 1993-1994 (Million Dollars)

\begin{tabular}{|c|c|c|c|}
\hline Region & 1993 & 1994 & $\begin{array}{c}\text { Percent Change } \\
\text { 1993-1994 }\end{array}$ \\
\hline \multicolumn{4}{|l|}{ United States } \\
\hline Onshore $\ldots \ldots \ldots \ldots \ldots \ldots \ldots \ldots$ & 7,214 & 7,808 & 8.2 \\
\hline Offshore $\ldots \ldots \ldots \ldots \ldots \ldots \ldots$ & 3,718 & 4,780 & 28.6 \\
\hline Total United States...$\ldots \ldots \ldots \ldots$ & $\cdot 10,932$ & 12,588 & 15.1 \\
\hline \multicolumn{4}{|l|}{ Foreign } \\
\hline Canada $\ldots \ldots \ldots \ldots \ldots \ldots \ldots$ & 1,559 & 1,835 & 17.7 \\
\hline OECD Europe $\ldots \ldots \ldots \ldots \ldots \ldots \ldots$ & 5,482 & 4,439 & -19.0 \\
\hline Former Soviet Union and Eastern Europe & 263 & 297 & 12.9 \\
\hline Africa $\ldots \ldots \ldots \ldots \ldots \ldots \ldots \ldots$ & 1,472 & 1,392 & -5.4 \\
\hline Middle East $\ldots \ldots \ldots \ldots \ldots \ldots \ldots$ & 685 & 445 & -35.0 \\
\hline Other Eastern Hemisphere .......... & 2,469 & 2,758 & 11.7 \\
\hline Other Western Hemisphere $\ldots \ldots \ldots \ldots$ & 616 & 743 & 20.6 \\
\hline Total Foreign . ............... & 12,546 & 11,909 & -5.1 \\
\hline Total FRS & 23,478 & 24,497 & 4.3 \\
\hline
\end{tabular}

Source: Energy Information Administration, Form ElA-28.

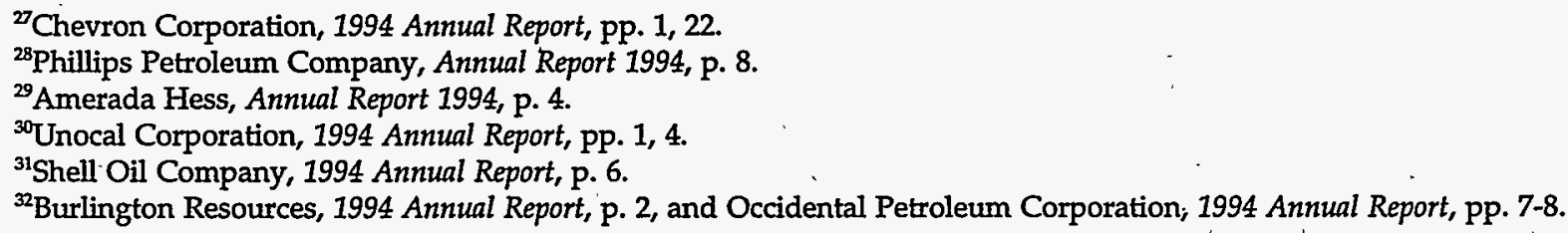




\section{North Sea: Early Infrastructure Continues to Pay Off}

The FRS companies' exploration and development spending in OECD Europe (for North Sea projects) has been declining since the early 1990's. Exploration expenditures fell 50 percent from 1991 (peak year) to 1994, and development spending fell more than 40 percent since 1992 (peak year). In spite of reduced capital spending, the FRS companies have increased crude oil production from the North Sea throughout the 1990's, and in 1994 produced 1.5 million barrels per day, up 25 percent from 1.2 million barrels per day in 1993 (Figure 13). Natural gas production also steadily increased.

Much of the recent surge in North Sea production is accomplished by means of technology which takes advantage of platforms built in the 1970's. Horizontal wells increase production from old fields and reach reservoirs too small to justify building a new platform. Other platform tie-ins, such as a project coordinating under-used pipelines by several different firms, also lend themselves to smaller fields. ${ }^{a}$ Redevelopment of existing platforms has the added benefit of putting off costly and politically unpopular abandonment of offshore installations. ${ }^{b}$ Floating production, storage, and offloading vessels have also been adapted, to produce from fields too small to justify a new platform and too far away to tie into existing platforms. ${ }^{\circ}$ After depleting a field, the vessel can move on to a new field.

Changes in tax regimes by the United Kingdom further encouraged production. In March 1993, the United

\section{Figure 13. FRS Companies' Oil and Gas Production in OECD Europe}

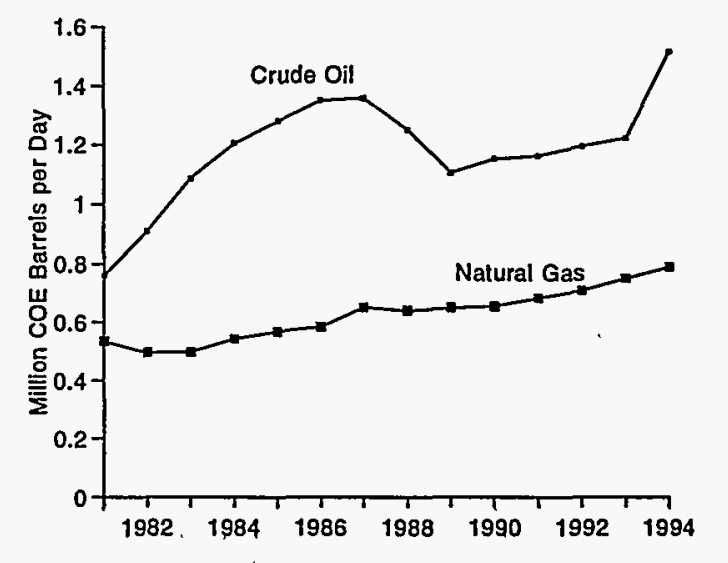

Source: Energy Information Administration, Form EIA-28. Kingdom reduced the Petroleum Revenue Tax on North Sea oil and gas from 75 to 50 percent of production, but revoked the tax credit for exploration. The.switch in policy had the effect of stimulating production from existing fields while dampening exploration efforts.

\footnotetext{
a"Under-estimating platform add-ons to take new subsea production," Offshore (March 1994), pp. 27-28.

"'Oil's Troubled Waters," Financial Times (January 11, 1995), p. 16, and "New Lease on Llfe for Rigs," Financial Times (January 11, 1995), p. 17.

"Watch Out for Floating Production Systems to Boost Those Bottom Lines," Intemational Petroleum Finance (April 1995), pp. 9-10.

duTax Reforms Raise Questions for Oil Industry in the U.K.," Oil and Gas Journal (August 30, 1993), p. 54.
}

In foreign regions, total exploration and development spending declined 5 percent from 1993 levels, to $\$ 11.9$ billion (Table 13). A widespread reduction of development spending on North Sea projects in OECD Europe contributed to the greatest portion of this decline (see the box entitled "North Sea: Early Infrastructure Continues to Pay Off"). The North Sea is a mature producing region with many platforms already in place, so that new development projects often tie in to existing facilities, reducing development cost. ${ }^{33}$ Low prices for Brent Blend crude in 1994 and complaints about the
Norwegian government's current tax regime also discouraged spending. ${ }^{34}$

\section{Gulf of Mexico Leads Upswing in Exploration}

Worldwide, the FRS companies' investment in oil and gas resources tend to emphasize either exploration or development, depending on a variety of factors, including oil prices. Throughout the period of falling oil prices, the FRS companies preferred to concentrate

\footnotetext{
33"Exploration Dips as Oil Prices Fall," Petroleum Economist (May 1994), p. 8.

${ }^{34}$ Petroleum Economist (May 1994), p. 8.
} 
on development, cutting back relatively more on exploration projects (Figure 14). Exploration carries more financial (as well as geological) risk, because reserves delineated by exploration efforts may take years to bring to market. Low oil prices mean longer payback times, increasing the risk of exploration projects. However, in 1994, the FRS companies spent $\$ 7.2$ billion on worldwide exploration, a 9-percent increase over record low spending in 1993. (Figure 14). The recovery of U.S. exploration spending may reflect expectations that worldwide economic growth will generate demand and future price increases. The recovery in exploration in the United States-was focused on offshore prospects. The FRS companies acquired more drilling acreage in the Federal Outer Continental Shelf (OCS) in the Gulf of Mexico.than in 1993 (Figure 15). Non-FRS companies were also active, acquiring 1.7 million acres in 1994.

Potential discoveries in the subsalt trend motivated these new OCS acquisitions. ${ }^{35}$ Oil and gas deposits in the Gulf of Mexico are often found around the sides and over the tops of salt structures. In the past, geologists speculated that hydrocarbons might also lie below the salt, but the high speed of sound through salt distorted seismic images, making it difficult to determine the actual depth of hydrocarbon pools. ${ }^{36}$ Recent advances in three-dimensional seismology have enabled exploration teams to design complex programs to correct distortions. ${ }^{37}$. The success of Phillips' Mahogany well in 1993 not only confirmed apparently commercial quantities of hydrocarbons, it validated the complex corrective techniques. ${ }^{38}$ As the result of Mahogany, Phillips acquired interests in 9 more subsalt blocks. ${ }^{39}$ Anadarko, a partner in the Mahogany project, was also an enthusiastic player in the 1994 OCS bidding. ${ }^{40}$

Competition among bidders for subsalt tracts increased prices for OCS acreage. ${ }^{41}$ Non-FRS companies bid an average of $\$ 126$ per acre, up from $\$ 76$ in 1993 (Figure 16). These smaller, independent producers have gained an increasing role in producing natural gas from the U.S. offshore (see the box entitled "FRS Companies Make Way for Independent Producers" on page 26).

Figure 14. Exploration and Development Expenditures for FRS Companies, 1981-1994

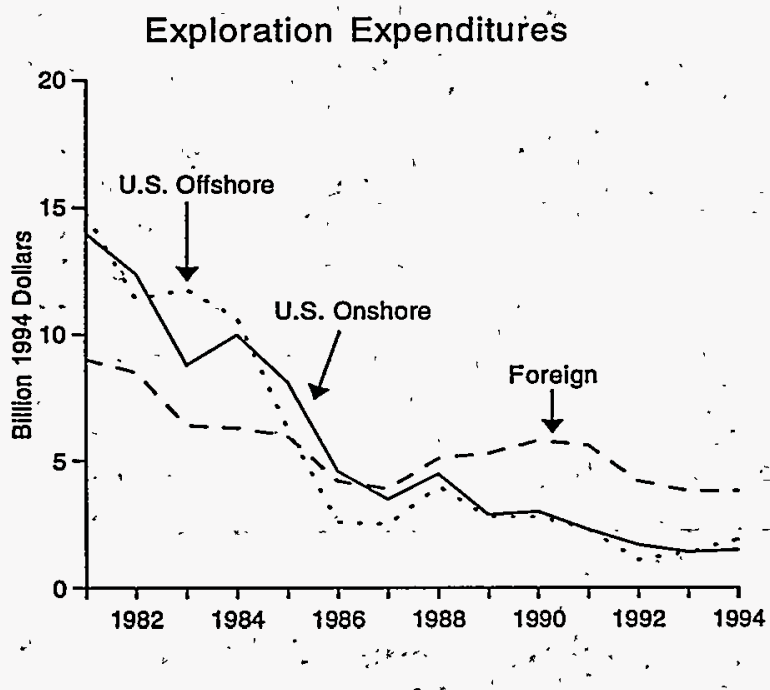

Note: Includes expenditures for unproved acreage.

Source: Energy Information Administration, Form ElA-28.

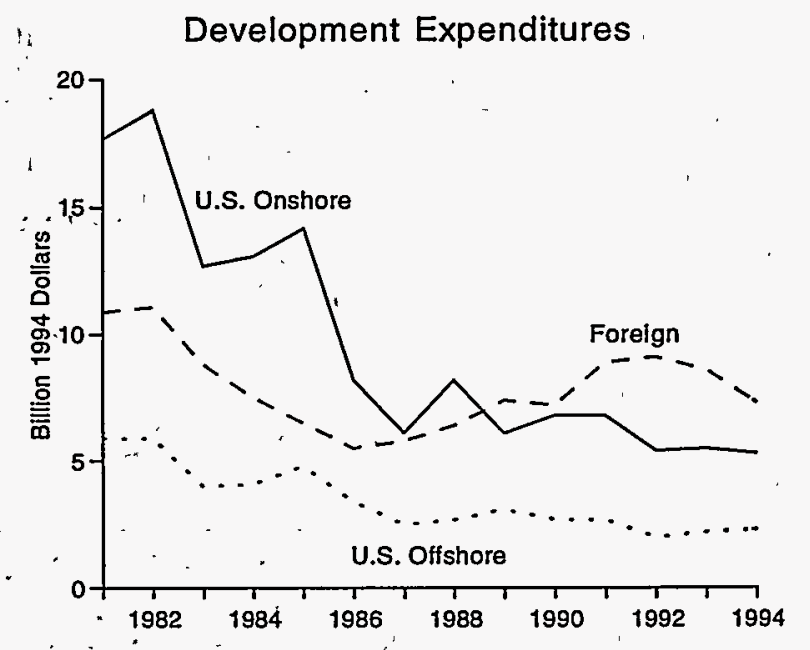

Note: Excludes expenditures for proved acreage.

Source: Energy Information Administration, Form EIA-28.

\footnotetext{
${ }^{35} \mathrm{~A}$ "trend" is made up of adjacent fields created by a common geological event: For example, the geological event creating the Gulf of Mexico subsalt trend was the flow of sediment from the Mississippi River. The sediment flow pushed saltdomes sideways, covering sands that eventually became oil reservoirs.

36"Understanding Salt Movement Key to Hot Gulf of Mexico Play," Oil and Gas Journal (May 2; 1994), p. 33.

${ }^{37}$ James F. Fox, Phillips Petroleum Company, Prepared Testimony before the Subcommittee on Oceanography, Gulf of Mexico and the Outer Continental Shelf, Committee on Marine and Fisheries, U.S. House of Representatives, May. 19, 1994.

${ }^{38}$ Oil and Gas Journal (May 2, 1994), p. 33.

${ }^{39}$ Phillips Petroleum Company, Annual Report 1994, p. 9.

${ }^{40}$ Oil and Gas Journal (May 2, 1994), p. 33.

${ }^{41}$ Oil and Gas Journal (May 2, 1994), p. 33.
} 
Figure 15. Outer Continental Shelf Acreage Awarded, 1990-1994

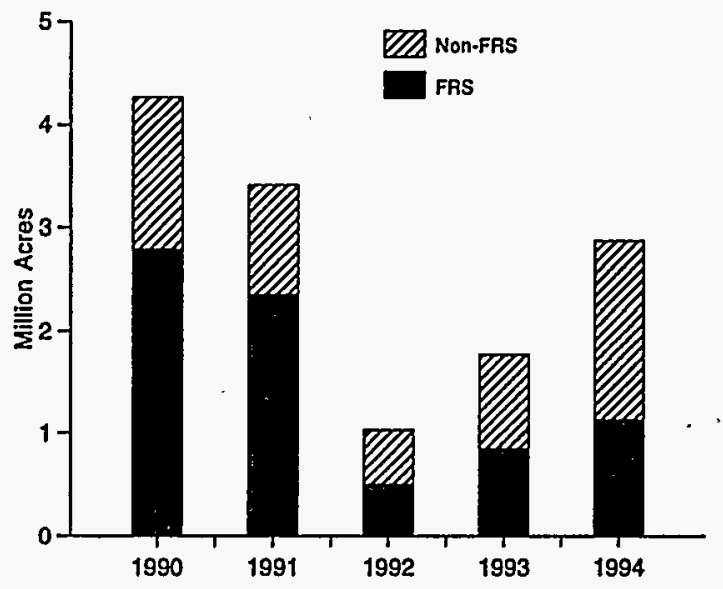

Source: Special compilation from the U.S. Department of the Interior, Minerals Management Service.

The FRS companies bid more conservatively for offshore acreage than did the independents but also paid more than in 1993 (Figure 16).

Deepwater prospects in the Gulf of Mexico have also recently become accessible through new technology. Improvements in design make it possible to use less steel for deepwater platforms, thereby reducing cost. ${ }^{42}$ Amoco booked "substantial reserves" in 1994 as a result of the deepwater Ram-Powell project, and successes such as this promoted interest in the 1995 OCS lease sale. ${ }^{43}$

\section{North American Natural Gas Drilling Increases}

In 1994, the FRS companies completed an almost record number of natural gas wells in the United States (Table 14), more than at any time in the past 10 years (with the exception of 1990). Many FRS companies view natural gas operations as the new cornerstone of U.S. upstream activity. For example, Chevron plans selected expansion into natural gas markets in North America, and $A m o c o$, the largest producer of natural gas in North America, plans to continue U.S. production
Figure 16. Outer Continental Shelf Cost per Acre, 1990-1994

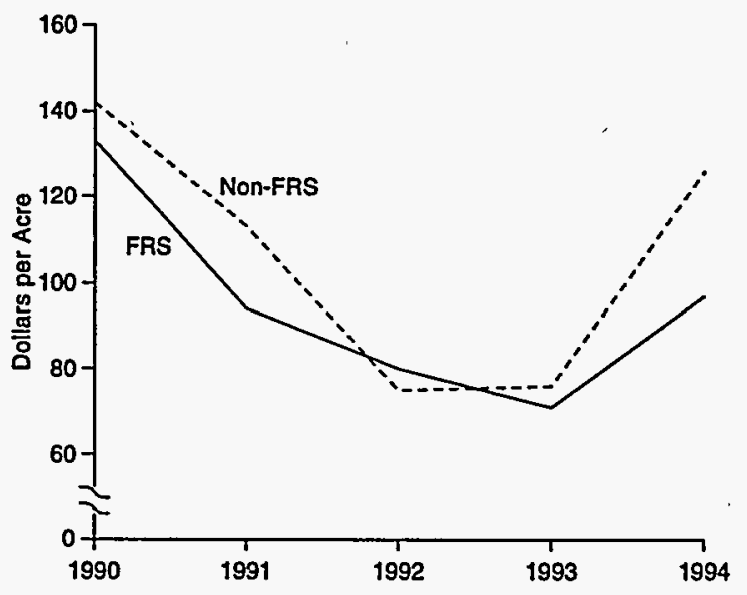

Source: Special compilation from the U.S. Department of the Interior, Minerals Management Service.

at current rates and to expand into downstream markets. ${ }^{44}$

Outside the United States, almost the entire increase in natural gas wells completed in 1994 was in Canada (Table 14). In 1994, the FRS companies received about the same price for sales of natural gas in Canada as they did in 1993, although U.S. natural gas prices fell (Table 12). ${ }^{45}$ Producers in the United States cannot sell appreciable quantities of natural gas to Canada to take advantage of price differences, because Canada imports less than one percent of natural gas for its own consumption from the United States. ${ }^{46}$ This cushions the Canadian market from a decline in U.S. natural gas prices. Drilling in Canada thus provides the FRS companies with a separate source of revenue, as well as gas for export to the United States.

\section{Finding Costs Resume Decline}

Total finding costs are defined as exploration and development expenditures, excluding expenditures on proved reserves, divided by reserve additions, excluding net purchases. Finding costs reflect the cost of replacing a producer's inventory of oil and gas.

\footnotetext{
12"Innovations Test New Frontiers," Petroleum Economist (April 1994), p. 6.

${ }^{43}$ Amoco Corporation, 1994 Annual Report, p. 10, and "OCS Sales 155 Shows Rebound in Gulf Prospects," Oil and Gas Journal (September 18, 1995), p. 36.

${ }^{41}$ Chevron Corporation, 1994 Annual Report, p. 14, and Amoco Corporation, 1994 Annual Report, pp. 11, 12.

${ }^{15}$ Energy Information Administration, Natural Gas Monthly, DOE/EIA-0130(95/08) (Washington, DC, August 1995), p. xii.

${ }^{46}$ Natural Resources Canada, Petroleum Monitoring and Energy Statistics Division, Canadian Petroleum Industry Monitoring Report 1994, (Ottawa, Ontario, August 1995), p. 109.
} 


\section{FRS Companies Make Way for Independent Producers}

As the FRS companies narrow the focus of their U.S. operations and look increasingly abroad for investment opportunities, smaller companies have gained a larger role in the U.S. oil and gas industry. Non-FRS producers

\section{Figure 17. Non-FRS Producers Expand U.S. Oil and Gas Operations}

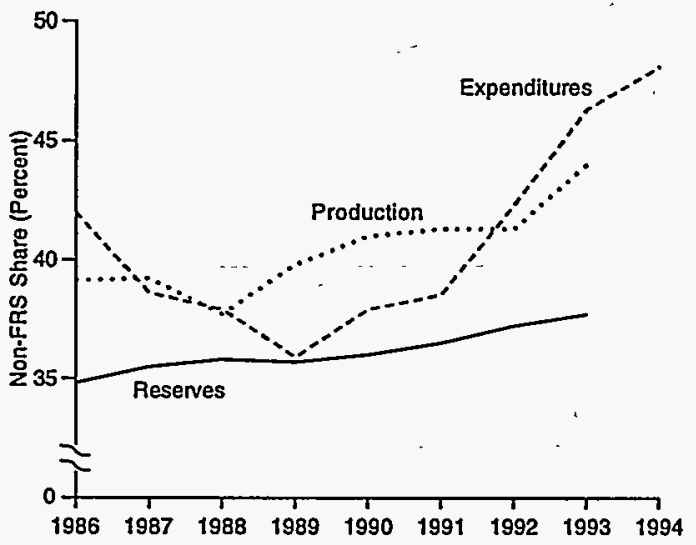

Note: Due to year-to-year volatility, expenditures are shown as a three-year moving average. Non-FRS = Total (less 15 percent for royalties) minus FRS companies.

Source: Energy Information Administration, Oil and Gas Development in the United States in the Early 1990's: An Expanded Role for Independent Producers, DOE/EIA-0600 (Washington, DC, October 1995).

companies replaced 66 percent of production through drilling, 11 percent through purchases, and the balance by increasing the rate of depletion. development expenditures from 1988-1990, but have increased expenditures to nearly 50 percent in recent years (Figure 17). ${ }^{\mathrm{a}}$ Non-FRS companies produced 45 percent of total U.S. oil and gas (on a net ownership basis) in 1993, up from to 39 percent in the late 1980's.

Offshore gas led the upswing in non-FRS production from 1986-1993. Production by non-FRS companies more than doubled, accounting for nearly 40 percent of U.S. offshore gas production by 1993. Initially, the non-FRS companies replaced over 100 percent of the offshore reserves they produced. However, after 1990, the non-FRS companies replaced only 22 percent of production through drilling, and another 27 percent through purchases. In the face of declining reserves, they supported production by increasing the rate of depletion, from about 17 percent in 1989 to nearly 25 percent in 1993.

Non-FRS companies increased their share of oil production from the onshore lower 48 States, from 45 percent in 1989 to 54 percent in 1993. This increase in share was partly due to FRS companies' scaled-back operations, but the non-FRS companies also increased their own production volumes by 12 percent. The non-FRS accounted for only one-third of total U.S. exploration and

${ }^{\text {a}}$ For an analysis of the increasing role of smaller oil and gas producers, see Energy Information Administration, Oil and Gas Development in the United States in the Early 1990's: An Expanded Role for Independent Producers, DOE/EIA-0600 (Washington, DC, October 1995).

Capital markets pay particular attention to finding costs (and reserve replacement costs) as an indicator of a company's ability to stay in the oil and gas production business (see the box entitled "Companies' Reserve Replacement "Costs Key to Survival" on page 28). The FRS companies themselves often emphasize finding cost reductions in their financial disclosures. ${ }^{47}$

In 1994, the FRS companies achieved the largest decline in finding costs since 1989 (Figure 18, Table 15). The decline in oil prices from 1993 to 1994 spurred companies' cost-cutting efforts, including adoption of cost-saving technology. Comparing the cost per barrel of reserves obtained by Shell's Auger and Mars platforms illustrates the speed of improvement in offshore technology. In 1989, the Auger platform ( $\$ 1.2$ billion) accessed 220 million barrels of reserves. ${ }^{48}$. Four years later, the technologically-superior Mars platform (also $\$ 1.2$ billion) accessed three times the reserves. Through technical improvements such as this, the FRS companies reduced finding costs for offshore operations 24 percent from 1993 (Table 15).

\footnotetext{
${ }^{47}$ Energy Information Administration, Oil and Gas Development in the United States in the Early 1990's: An Expanded Role for Independent Producers, DOE/EIA-0600 (Washington, DC, October 1995), p. 25; John S. Herold, Inc, Herold's Reserve Replacement Cost Analysis, (Greenwich, Connecticut, July 1992), p. 1; Amoco Corporation, Annual Report 1988, p. 4; Phillips Petroleum Company, 1993 Annual Report, pp. 5, 8, and Unocal Corporation, 1994 Annual Report, pp. 4, 6.

48“Innovations Test New Frontiers," Petroleum Economist (April 1994), p. 6.
} 
Table 14. Well Completions by Region for FRS Companies, 1992-1994

\begin{tabular}{|c|c|c|c|c|c|c|}
\hline \multirow[b]{2}{*}{ Region } & \multicolumn{3}{|c|}{ Oil Wells } & \multicolumn{3}{|c|}{ Gas Wells } \\
\hline & 1992 & 1993 & 1994 & 1992 & 1993 & 1994 \\
\hline \multicolumn{7}{|l|}{ United States } \\
\hline$\ldots \ldots \ldots \ldots$ & 1,776 & 2,074 & 2,081 & 1,709 & 1,791 & 2,032 \\
\hline Offshore $\ldots \ldots \ldots \ldots \ldots \ldots \ldots$ & 131 & 147 & 163 & 71 & 140 & 167 \\
\hline Total United States ............. & 1,907 & 2,221 & 2,244 & 1,780 & 1,931 & 2,199 \\
\hline \multicolumn{7}{|l|}{ Foreign } \\
\hline Canada & 231 & 383 & 216 & 69 & 340 & 522 \\
\hline$\ldots \ldots \ldots \ldots$ & 54 & 72 & 74 & 38 & 43 & 36 \\
\hline Other Eastern Hemisphere . . . . . . . . & 130 & 133 & 127 & 82 & 79 & 60 \\
\hline Other $\ldots \ldots \ldots \ldots \ldots \ldots \ldots \ldots$ & 200 & 176 & 213 & 8 & 8 & 12 \\
\hline Total Foreign $\ldots \ldots \ldots \ldots \ldots \ldots \ldots$ & 615 & 763 & 630 & 196 & 470 & 630 \\
\hline
\end{tabular}

${ }^{a}$ Europe includes OECD Europe, Eastern Europe, and the Former Soviet Union.

bOther regions include Africa, the Middle East, and Other Western Hemisphere.

Source: Energy Information Administration, Form EIA-28.

Figure 18. U.S. and Foreign Finding Costs Decline

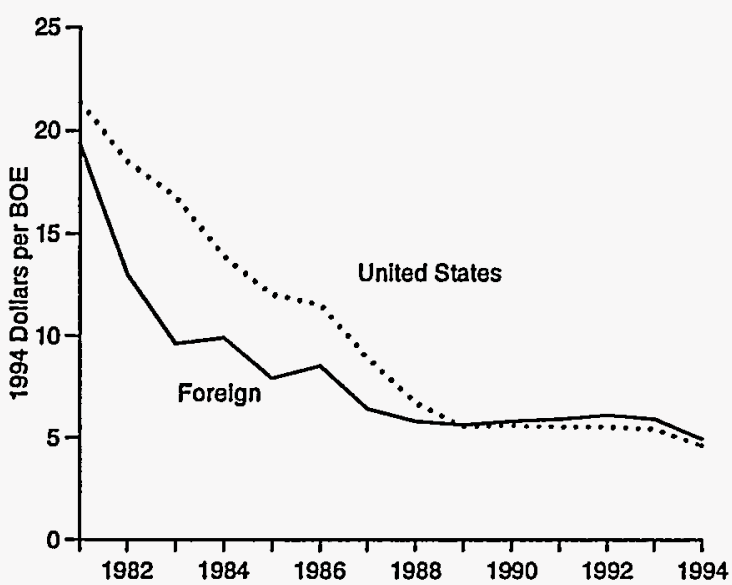

$B O E=$ Barrels of crude oil equivalent.

Note: Finding costs are 3-year weighted averages of exploration and development expenditures, excluding expenditures for proved acreage, divided by reserve additions, excluding net purchases. Reserve additions exclude BP America's and Exxon's total 1987 downward revisions of Alaska North Slope natural gas reserves of 13.461 trillion cubic feet, and Arco's 1985 downward revisions of 8.300 trillion cubic feet. Gas is converted to barrels of oil equivalent on the basis of 0.178 barrels of oil per thousand cubic feet of gas.

Source: Energy Information Administration, Form ElA-28.
The FRS companies reduced finding costs almost universally in foreign regions, and especially in Canada. The decline in Canada was the result of large reserve additions booked by the larger operators in Canada, who generally incur lower costs. The single region where the FRS companies increased finding costs in 1994 was the Other Eastern Hemisphere, where several companies have embarked on long-term liquefied natural gas (LNG) projects whose reserves will probably not be booked for several years (see the box entitled "Opportunities in LNG" on page 31). Mobil began developing Indonesian gas fields to meet anticipated demand later in this decade. ${ }^{49}$ Exxon's $\$ 40-$ billion LNG project with Indonesia is expected to take eight years to complete, in anticipation of an increase in demand by Japan. 50

\section{Production Taxes Decline with Oil Prices}

Production (or lifting) costs are the costs of extracting oil and gas, and include operating (direct lifting) costs, as well as production taxes. Several regions typically have high direct lifting costs per barrel, either because field sizes are small (Canada and lower-48 onshore United States), or because production equipment is expensive to operate (the North Sea). Direct lifting costs for U.S. operations declined slightly from 1993 levels, as did foreign direct lifting costs (Table 16).

\footnotetext{
${ }^{49}$ Mobil Corporation, 1994 Mobil Fact Book, p. 34.

50"Exxon's Indonesian LNG Pact on Course," Financial Times (December 7, 1994), p. 17.
} 


\section{Companies' Reserve Replacement Costs Key to Survival}

Survivois of the 1986 oil price collapse, whether FRS companies or independent producers, have reduced their cost of replacing reserves depleted by production.

Figure 19. U.S. Reserve Replacement Costs

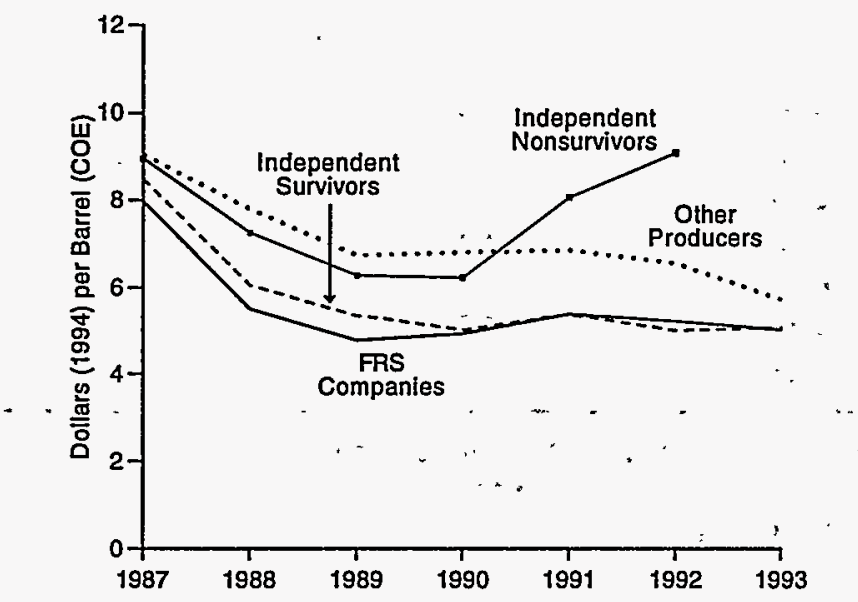

$\mathrm{COE}=$ Crude oil equivalent.

Note: Reserve replacement costs = Exploration and development expenditures (including acquisitions of unproved and proved acreage)/reserves added (including purchases of proved reserves), three-year weighted average. Independent oil and gas producers' primary industry is Standard Industrial Code 13.

Source: Energy Information Administration, Oil and Gas Development in the United States in the Early 1990's: An Expanded Role for Independent Producers, DOE/EIA-0600 (Washington, DC, October 1995):

successful than the nonsurvivors in continuing to reduce development costs. By the 1990's, surviving independent producers replaced reserves at about the same cost as the FRS companies.

\footnotetext{
aEnergy Information Administration, Oil and Gas Development in the United States in the Early 1990's: An Expanded Role for Independent Producers, DOE/EIA-0600 (Washington, DC, October 1995), p. 15.

${ }^{b}$ Oil and Gas Development in the United States in the Early 1990's: An Expanded Role for Independent Producers, pp. $19-25$.
}

Also contributing to the decline in total lifting costs in 1994 were lower production taxes. Most production taxes are levied on the value of oil and gas produced (see the box entitled "Severance Taxes," Chapter 2).
The cost to a company of replacing its oil and gas production is often measured by the reserve replacement cost. ${ }^{a}$ Reserve replacement costs are similar to finding costs, except that they include expenditures for proved acreage and the corresponding reserves added through purchases. The FRS companies operating in 1986 all survived the oil price collapse and reduced reserve replacement costs from about $\$ 8.00$ per barrel in 1987 to about $\$ 5.00$ in the 1990's (1994 dollars) (Figure 19).

In contrast, many independent producers did not survive the oil price collapse. Survivors differed little from nonsurvivors in terms of frequently-used measures of financial performance. ${ }^{b}$ Survivors were not consistently more profitable than nonsurvivors. Survivors did not consistently pay less for borrowed funds than nonsurvivors. Comparison of the value of shares to the book value of assets indicated no preference by the capital markets for the survivors over the nonsurvivors.

The one remarkable difference between the surviving and nonsurviving independent oil and gas producers was the cost of reserve replacement. The survivors of the oil price collapse incurred lower costs than the nonsurvivors from the very beginning of the period (Figure 19). They were also more 
Table 15. Finding Costs by Region for FRS Companies, 1993-1994

(Dollars per Barrel of Oil Equivalent)

\begin{tabular}{|c|c|c|c|}
\hline Region & 1993 & 1994 & $\begin{array}{c}\text { Percent Change } \\
\text { 1993-1994 }\end{array}$ \\
\hline \multicolumn{4}{|l|}{ United States } \\
\hline Onshore & 4.83 & 4.62 & -4.5 \\
\hline$\ldots \ldots \ldots \ldots \ldots \ldots \ldots \ldots \ldots$ & 5.73 & 4.38 & -23.6 \\
\hline Total United States . . . . . . . . . . . . & 5.11 & 4.53 & -11.2 \\
\hline \multicolumn{4}{|l|}{ Foreign } \\
\hline$\ldots \ldots \ldots \ldots$ & 10.63 & 6.44 & -39.4 \\
\hline OECD Europe $\ldots \ldots \ldots \ldots \ldots \ldots \ldots \ldots$ & 7.32 & 5.21 & -28.7 \\
\hline Africa $\ldots \ldots \ldots \ldots \ldots \ldots \ldots \ldots \ldots$ & 4.56 & 3.52 & -22.8 \\
\hline Middle East $\ldots \ldots \ldots \ldots \ldots \ldots \ldots \ldots$ & 4.83 & 3.88 & -19.6 \\
\hline Other Eastern Hemisphere $\ldots \ldots \ldots \ldots \ldots \ldots$ & 3.47 & 4.96 & 43.2 \\
\hline Other Western Hemisphere .. & 4.48 & 3.39 & -24.3 \\
\hline Total Foreign $\ldots \ldots \ldots \ldots \ldots \ldots \ldots$ & 5.62 & 4.84 & -13.9 \\
\hline Worldwide Total $\ldots \ldots \ldots \ldots \ldots \ldots \ldots \ldots$ & 5.37 & 4.69 & -12.6 \\
\hline
\end{tabular}

Note: The above figures are 3-year weighted averages of exploration and development expenditures, excluding expenditures for proved acreage, divided by reserve additions, excluding net purchases. Gas is converted to barrels of oil equivalent on the basis of 0.178 barrels of oil per thousand cubic feet of gas.

Source: Energy Information Administration, Form EIA-28.

was in contrast to last years' action, when the province instituted a permanent twelve-month holiday for new exploration wells and allowed new crude oil development wells to produce royalty-free for a year. ${ }^{52}$ Amoco, one of the largest FRS producers in Canada, reported a 31-percent increase in production taxes paid from 1993, even though the companies' production of oil and gas declined 14 percent from $1993 .^{53}$

\section{Offshore, Overseas, and Natural Gas Reserves Increase}

The FRS companies added 5.7 billion crude-oilequivalent barrels of worldwide reserves in 1994, a record level. Additions to proved reserves in 1994 reflected the FRS companies' focus on investment in offshore natural gas and in foreign regions (Table 17). The FRS companies ended 1994 with less onshore oil and gas than they had begun the year with, but offshore gas reserves increased 8 percent, to 20.7 trillion cubic feet. The companies continued to increase foreign reserves more than U.S. reserves, as they have since 1987 in the aftermath of the oil price collapse. ${ }^{54}$

In onshore operations, the FRS companies produced oil and gas faster than they added reserves, replacing 62 percent of oil production and 78 percent of gas production in 1994. However, replacement rates were higher than in 1993 for both U.S. and foreign regions, in both oil and gas. In the United States, lower oil and gas prices brought forth only modest increases in production. In foreign regions, substantial increases in production were supported by proportionally larger reserve additions. Within each region, production replacement ratios for natural gas were higher than for oil, as companies build ahead of anticipated worldwide increases in demand.

\footnotetext{
${ }^{52}$ Canadian Oil Markets and Emergency Planning Division, The Canadian Oil Market Annual Review for 1993 (Ottawa, Ontario, July 1994), p. 5.

${ }^{53}$ Amoco Corporation, 1994 Annual Report, pp. 49, 51.

${ }^{54}$ Energy Information Administration, Performance Profiles of Major Energy Producers 1993, DOE/EIA-0206(93) (Washington, DC, January 1995), p. 83.
} 
Table 16. Lifting Costs by Region for FRS Companies, 1993-1994 (Dollars Per Barrel of Oil Equivalent)

\begin{tabular}{|c|c|c|c|c|c|c|c|c|c|}
\hline \multirow[b]{2}{*}{ Region } & \multicolumn{3}{|c|}{ Direct Lifting Costs } & \multicolumn{3}{|c|}{ Production Taxes } & \multicolumn{3}{|c|}{ Totál } \\
\hline & 1993 & $1994^{\circ}$ & $\begin{array}{l}\text { Percent } \\
\text { Change }\end{array}$ & 1993 & 1994 & $\begin{array}{l}\text { Percent } \\
\text { Change }\end{array}$ & 1993 ; & 1994 & $\begin{array}{l}\text { Percent } \\
\text { Change }\end{array}$ \\
\hline \multicolumn{10}{|l|}{ United States } \\
\hline Onshore & -- & -- & $\therefore$ & -- & $\therefore$ & -- & 5.00 & 4.64 & -7.2 \\
\hline Offshore & -- & -- & -- & -- & -- & -. & 3.32 & 3.15 & -5.1 \\
\hline Total United States . . . . & 3.93 & 3.68 & -6.4 & 0.64 & 0.57 & -10.5 & . 4.57 & 4.25 & -7.0 \\
\hline \multicolumn{10}{|l|}{ Foreign } \\
\hline Canada . & 3.51 & 3.47 & -1.1 & 0.22 & $0: 28$ & 30.0 & 3.72 & 3.75 & 0.7 \\
\hline OECD Europe & 5.02 & 4.90 & -2.4 & 0.72 & 0.57 & -20.9 & 5.74 & $5.47^{\circ}-1-1+1$ & 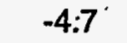 \\
\hline Africa ....... & 3.46 & 3.08 & -10.8 & 1.27 & 1.13 & -10.9 & 4.72 & 4.21 & -10.8 \\
\hline Middle East $\ldots \ldots \ldots \ldots \ldots$ & 3.20 & 3.47 & 8.2 & 1.14 & 0.97 & -14.8 & .4 .34 & 4.43 & 2.2 \\
\hline Other Eastern Hemisphere : & 2.28 & 2.15 & -5.8 & 1.22 & 0.82 & -32.9 & 3.50 & 2.97 & -15.3 \\
\hline Other Western Hemisphere & 3.08 & 2.63 & -14.6 & 1.00 & 0.63 & -37.2 & 4.08 & 3.26 & -20.2 \\
\hline Total Foreign & 3.69 & $3.61^{\circ}$ & -2.1 & $0.86^{\circ}-$ & $0 . \overline{6} 7$ & -22.3 & 4.55 & 4.27 & -5.9 \\
\hline Worldwide Total & 3.83 & 3.65 & $-4.8^{\circ}$ & 0.73 & 0.61 & -16.0 & 4.56 & 4.26 & -6.6 \\
\hline
\end{tabular}

- = Data not available.

Note: Sum of components may not equal total due to independent rounding.

Source: Energy Information Administration, Form EIA-28.

Table 17. Oil and Gas Reserves and Production for FRS Companies, 1993-1994

\begin{tabular}{|c|c|c|c|c|c|c|}
\hline \multirow{2}{*}{ Reserves and Production } & \multicolumn{2}{|c|}{ U.S. Onshore } & \multicolumn{2}{|c|}{ U.S. Offshòre } & \multicolumn{2}{|c|}{ Foreign } \\
\hline & 1993 & .1994 & 1993 & 1994 & 1993 & 1994 \\
\hline \multicolumn{7}{|l|}{ Oil (million barrels) } \\
\hline Reserve Additions . & 775 & 802 & 360 & 359 & 1,313 & 1,809 \\
\hline Net Purchases & -91 & -18 & -64 & -9 & 995 & 90 \\
\hline Production ... & 1,297 & 1,297 & 307 & 297 & 1,320 & 1,419 \\
\hline Total Oil Reserves .. & 14,697 & 14,185 & 2,777 & 2,829 & 12,878 & 13,359 \\
\hline 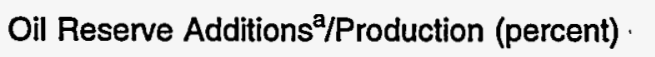 & 58 & 62 & 117 & 121 & 99 & 127 \\
\hline \multicolumn{7}{|l|}{ Natural Gas (billion cubic feet) } \\
\hline Reserve Additions . . . . . . . & 3,884 & 4,081 & 2,770 & 3,990 & 6,107 & 7,141 \\
\hline Net Purchases $\ldots \ldots \ldots \ldots \ldots \ldots \ldots$ & -631 & 470 & -597 & 269 & 741 & 22 \\
\hline Production $\ldots \ldots \ldots \ldots \ldots \ldots \ldots$ & 5,089 & 5,244 & 2,562 & 2,754 & 4,099 & 4,312 \\
\hline Total Gas Reserves . ............... & 58,242 & 57,550 & 19,244 & 20,748 & 56,620 & 59,472 \\
\hline Gas Reserve Additions ${ }^{\mathrm{a} / P r o d u c t i o n}$ (percent) & 76 & 78 & 108 & 145 & 149 & 166 \\
\hline
\end{tabular}

${ }^{a}$ Excludes net purchases and sales.

Note: Sum of components may not equal total due to independent rounding.

Source: Energy Information Administration, Form EIA-28. - 


\section{Opportunities in LNG}

Demand for natural gas is expected to increase worldwide, especially in the growing economies of the Far East. Much of the expected new demand will be for electric power generation. ${ }^{a}$ Natural gas burns more cleanly than petroleum fuels or coal, and new gas-fired combined-cycle turbine power plants can turn heat into electricity more efficiently than other generating equipment. The major importers of natural gas in the Far East (Japan, South Korea, and Taiwan) are separated by oceans from the main producers (Indonesia, Malaysia, and Australia), generating an active maritime trade in liquefied natural gas (LNG). ${ }^{b}$ This transport requirement means that exploration and development of gas in the Far East is often just the first step in a complex, vertically integrated project. The natural gas provider must build a liquefaction plant, order ships, and often construct a harbor." At the receiving end, the provider might build the port and re-gasification plant, and the electric power plant that will burn the natural gas. ${ }^{d}$

Despite these complexities, the FRS companies find LNG projects attractive investment targets. Mobil has a new joint venture with Pertamina, Indonesia's state energy company. Shell has projects in Malaysia, Oman and Nigeria. In 1994, Exxon signed a joint venture with Pertamina, in a project to develop an offshore gas field in the South China sea. Upon completion, the project will be the largest offshore natural gas development project in the world. ${ }^{\circ}$ In 1994, Enron and Qatar agreed to develop a massive new LNG project aimed at the Israeli and Indian markets.' Outside Asia, Amoco signed a joint venture to develop a new LNG plant in Trinidad. ${ }^{9}$

Although a vertically integrated project has many points at which revenues are generated, several oil companies have chosen the first stage, natural gas production, as the center of profit. Mobil intends to operate its LNG projects to "maximize the value of the gas at the wellhead." Enron's purpose in investing in power and pipeline projects is to add value to its reserves and production.'

\footnotetext{
${ }^{a}$ Enron Corporation, 1994 Annual Report to Shareholders and Customers, p. 8.

${ }^{b}$ APS Review of Gas Market Trends (October 10, 1994).

"'LNG Ventures Raise Economic, Technical, Partnership Issues," Oil and Gas Journal (July 3, 1995), pp. 34-35.

'Oil and Gas Joumal (July 3, 1995), pp. 34-35.

${ }^{\circ}$ East Asian Affairs (November 30, 1994) Indonesia Section.

'The Reuter European Business Report (January 23, 1995).

${ }^{9}$ Caribbean Update (September 1995).

hOll and Gas Joumal (July 3, 1995), p. 34.

JEnron Corporation, 1994 Annual Report, pp. 25, 33.
} 



\section{Downstream Petroleum in 1994}

\section{U.S. Refining}

For the fifth straight year, the FRS companies' financial performance in U.S. refining/marketing generally was below that of other petroleum operations (Table 3 in Chapter 2). Low refined product margins worked to depress earnings in 1994. However, as in recent years, the year 1994 was also marked by further consolidation and reduction of downstream operations driven by the need to reduce operating costs in the face of historically high environmental expenditures.

The U.S. economy grew 4 percent in $1994,{ }^{55}$ resulting in, a 3-percent increase in overall domestic refined product demand. ${ }^{56}$ For the FRS companies, refined product sales volume was up 2 percent in 1994 (Table 18). The increase was due entirely to higher sales of residual fuel and other refined products. Between 1993 and 1994, the FRS companies reported lower distillate sales and nearly flat gasoline sales. In contrast, overall U.S. gasoline demand rose 2 percent between 1993 and $1994,{ }^{57}$ an increase met mostly by increased imports and by the non-FRS refiners.

\section{Poor U.S. Margins Outweigh Cost Reductions}

Despite the increase in sales volume, the FRS companies reported a 2-percent decline in sales revenue, as refined product prices fell more steeply than crude

Table 18. Sales, Expenses, and Income in U.S. Refining/Marketing for FRS Companies, 1993-1994

\begin{tabular}{|c|c|c|c|}
\hline Sales, Expenses, and Income & 1993 & 1994 & $\begin{array}{c}\text { Percent Change } \\
1993-1994\end{array}$ \\
\hline & \multicolumn{2}{|c|}{ (million barrels per day) } & \\
\hline \multirow[t]{2}{*}{ Refined Product Sales . ................... } & 13.2 & 13.4 & 1.7 \\
\hline & \multicolumn{2}{|c|}{ (dollars per barrel sold) } & \\
\hline \multicolumn{4}{|l|}{ Average Sales Price } \\
\hline Gasoline ...... & 27.27 & 26.01 & -4.6 \\
\hline Distillate $\ldots \ldots \ldots \ldots \ldots \ldots \ldots \ldots \ldots$ & 23.61 & 21.96 & -7.0 \\
\hline Other $\ldots \ldots \ldots \ldots \ldots \ldots \ldots \ldots \ldots \ldots \ldots \ldots$ & 19.50 & 19.78 & 1.4 \\
\hline All Refined Products $\ldots \ldots \ldots \ldots \ldots \ldots \ldots \ldots$ & 24.46 & 23.37 & -4.4 \\
\hline Raw Material Input and Product Purchases per Barrel .... & 17.69 & 17.40 & -1.6 \\
\hline $\begin{array}{l}\text { Average Sales Price Less Cost of Raw Materials } \\
\text { and Product Purchases (Gross Margins) } \ldots \ldots \ldots \ldots\end{array}$ & 6.77 & 5.97 & -11.8 \\
\hline Direct Operating Costs $\ldots \ldots \ldots \ldots \ldots \ldots \ldots$ & 6.06 & 5.26 & -13.3 \\
\hline Refined Product Margin ${ }^{a} \ldots \ldots \ldots \ldots \ldots \ldots \ldots$ & 0.71 & 0.71 & 0.4 \\
\hline
\end{tabular}

aSee Appendix B, Table B48, for the components to calculate the refined product margin.

$-=$ Not meaningful.

Note: Sum of components may not equal total due to independent rounding. Percent changes were calculated from unrounded data.

Source: Energy Information Administration, Form EIA-28.

\footnotetext{
${ }^{55}$ Energy Information Administration, Annual Energy Review 1994, DOE/EIA-0384(94) (Washington, DC, July 1995), Table E1.

${ }^{56}$ Energy Information Administration, Monthly Energy Review September 1995, DOE/EIA-0035(95/09) (Washington, DC, September 1995), Table 3.1a.

${ }^{57}$ Monthly Energy Review September 1995, Table 3.4.
} 
oil input prices. As a result, the FRS companies saw their gross margins falling by nearly a dollar to $\$ 5.97$ per barrel in 1994 (Table 19). The decline in gross margins was in large measure offset by reduced operating costs, as the FRS companies continued to restructure their refining operations. Still, after adjusting for the effects of special one-time charges, the FRS companies reported a drop in net income from their U.S. refining/marketing operations (Table 20).

The FRS companies were particularly effective in reducing their marketing costs in 1994, as they have been since the mid-1980's (Table 19). Between 1993 and
1994, marketing costs fell 42 cents (19 percent) to $\$ 1.80$ per barrel. Further, energy costs fell by 24 cents per barrel (20 percent), while other operating costs fell by 27 cents per barrel (10 percent) in 1994.

\section{U.S. Environmental Requirements Reflected in Capital Expenditures}

The year 1994 saw a continuation in the consolidation of the FRS companies' downstream operations and a slight reduction in their role in. U.S. refined product markets. The FRS companies reduced their U.S. refining

Table 19. FRS U.S. Refined Product Margins and Costs per Barrel Sold, Selected Years, 1977-1994 (1994 Dollars per Barrel)

\begin{tabular}{|c|c|c|c|c|c|c|}
\hline & 1977 & 1981 & 1985 & 1989 & 1993 & 1994 \\
\hline $\begin{array}{l}\text { Gross Margin } \\
\text { less }\end{array}$ & 7.75 & 10.81 & 9.73 & 7.69 & 6.91 & 5.97 \\
\hline Marketing Costs $\ldots \ldots \ldots \ldots \ldots$ & 1.95 & 2.81 & 2.86 & 2.11 & 2.22 & 1.80 \\
\hline Energy Costs $\ldots \ldots \ldots \ldots \ldots \ldots \ldots \ldots$ & 1.77 & 3.34 & 2.22 & 1.23 & 1.20 & 0.96 \\
\hline $\begin{array}{l}\text { Other Operating Expense } \ldots \ldots \ldots \ldots \ldots \ldots \\
\text { equals }\end{array}$ & 2.74 & 3.34 & 3.18 & 2.62 & 2.77 & 2.50 \\
\hline FRS Refined Product Margin ${ }^{\mathrm{b}}$ & 1.29 & 1.32 & 1.46 & 1.72 & 0.73 & 0.71 \\
\hline Refined Product Sales Volume (mbd).. & 14,621 & 12,237 & 12,547 & 13,486 & 13,178 & 13,398 \\
\hline
\end{tabular}

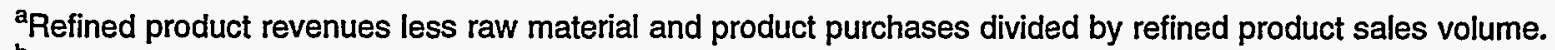

${ }^{b}$ Calculated from unrounded data.

Source: Energy Information Administration, Form EIA-28.

Table 20. Refining/Marketing Financial Items, for FRS Companies, 1993-1994

\begin{tabular}{|c|c|c|c|c|}
\hline & \multicolumn{2}{|c|}{ United States } & \multicolumn{2}{|c|}{ Foreign } \\
\hline & 1993 & 1994 & 1993 & 1994 \\
\hline Refined Product Revenues & 117,647 & 114,790 & 115,376 & 117,290 \\
\hline plus Other Revenues ${ }^{a}$ & 11,528 & 11,390 & 3,589 & 3,877 \\
\hline minus Total Operating Expenses ${ }^{a, b}$ & 124,760 & 122,491 & 114,329 & 117,000 \\
\hline equals Operating Income ${ }^{b} \ldots \ldots \ldots$ & 4,415 & 3,689 & 4,636 & 4,167 \\
\hline Net Income, excluding unusual items & 2,911 & 2,290 & 3,496 & 2,743 \\
\hline Unusual Items $\ldots \ldots \ldots \ldots \ldots \ldots \ldots$ & $(1,226)$ & (445) & (303) & (746) \\
\hline Net Income $\ldots \ldots \ldots \ldots \ldots \ldots \ldots$ & 1,685 & 1,845 & 3,193 & 1,997 \\
\hline \multicolumn{5}{|l|}{ Ratios } \\
\hline Rate of Return $\ldots \ldots \ldots \ldots \ldots \ldots \ldots$ & 3.4 & 3.6 & 10.6 & 6.1 \\
\hline Effective Tax Rate $\ldots \ldots \ldots \ldots \ldots \ldots$ & 38.3 & 41.3 & 33.8 & 35.0 \\
\hline
\end{tabular}

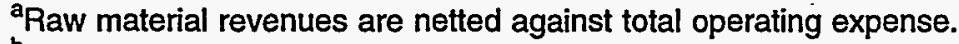

bExcludes unusual items.

Source: Energy Information Administration, Form EIA-28. 
capacity by 45,000 barrels per day (b/d) in $1994 .^{58}$ As a result, the FRS companies accounted for 65 percent of total U.S. refining capacity versus 68 percent in 1993 (Table B45). Part of the reduction in refining capacity reflected Amerada Hess mothballing its $30,000 \mathrm{~b} / \mathrm{d}$ Purvis, Alabama, refinery. ${ }^{59}$ In 1994, Unocal and Exxon also reported reduced refining capacity, but no closure of any refineries. Chevron sold its $172,000 \mathrm{~b} / \mathrm{d}$ Philadelphia refinery in 1994 to Sun, which is also an FRS company. Hence, the sale had no effect on overall FRS company domestic refining capacity. Sun integrated the former Chevron refinery into its adjacent Philadelphia downstream refining operations, creating the biggest refinery on the East Coast. Although as a group the FRS companies reduced refinery capacity in 1994 (see the box entitled "Specialized Refiners Increase Role in U.S. Refining"), a number of FRS companies reported increasing capacity incrementally at several of their refineries. ${ }^{60}$

\section{Specialized Refiners Increase Role in U.S. Refining}

The FRS companies have been reducing their share of U.S. refining for several years. Ten years ago, the FRS companies accounted for 78 percent of total U.S. refining capacity, versus 65 percent in 1994. Ten years ago the FRS companies' operated 101 refineries in the United States, versus 74 in 1994. Partial and whole refinery shutdowns account for some of the reduced FRS role in U.S. refining. Some of the more recent shutdowns include Chevron which has reduced its capacity at its Port Arthur, Texas, refinery by $131,000 \mathrm{~b} / \mathrm{d}$ since $19911^{\text {a }}$ Since 1993, Coastal shut down two small refineries and DuPont, one small refinery. Refinery sales to foreignowned companies and to independent refineries accounted for the remaining reduction in FRS refining capacity. In April 1993, Shell sold a half interest in its Deer Park, Texas, refinery to Pemex, Mexico's state oil company; one month later, Amoco sold its Savannah, Georgia, refinery to Citgo Petroleum Corporation, the wholly-owned subsidiary of PDVSA, the Venezuelan state-owned petroleum company. During the same year, ARCO's subsidiary, Lyondell Petrochemical, formed a joint venture with Citgo to upgrade Lyondell's $265,000 \mathrm{~b} / \mathrm{d}$ Houston, Texas, refinery. Following on from the reductions in 1994 capacity cited earlier in this report by Amerada Hess, Exxon, and Unocal, it appears that the FRS companies will again report a reduction in their share of U.S. refining in 1995. In February of 1995, Chevron sold its Port Arthur refinery to Clark Refining and Marketing, the U.S. subsidiary of the Canadian-based Horsham Corporation.

As the role of the FRS companies in U.S. refining has receded, the role of non-FRS refiners has grown. In April of 1993, the independent refining company, Tosco Corporation, purchased Exxon's 200,000 b/d Bayway, New Jersey, refinery and, in January of 1994, Tosco purchased BP America's 84,000 b/d Ferndale, Washington, refinery. In 1995, Kerr-McGee announced its total withdrawal from U.S. refining, and sold its three refineries to independent refiners. Kerr-McGee sold its Wynnewood, Oklahoma, refinery to Gary-Williams Energy Corp, its Cotton Valley, Louisiana, refinery to Calumet Lubricants, and its Corpus Christi, Texas, operation to Koch Industries. Kerr-McGee also sold its Oklahoma City-based Cato Oil and Grease subsidiary to Citgo.' In addition to the Corpus Christi refinery purchase, Koch has been one of the few companies in recent years to add substantial amounts of capacity to existing refineries. In 1994, Koch added 140,000 barrels per day of refining capacity, making the privately-held Koch the nation's largest independent refiner. ${ }^{\circ}$ In 1995, Koch acquired 1,400 miles of crude oil pipeline from Exxon. ${ }^{d}$ It appears that the role of the independents will continue to grow in the future. In 1995-1997, a number of independent refiners have reported plans to add over $100,000 \mathrm{~b} / \mathrm{d}$ in capacity.

\footnotetext{
EEnergy Information Administration, Petroleum Supply Annual 1991, DOE/EIA-0340(91)/1 (Washington, DC, June 1992), p. 114; and Energy Information Administration, Petroleum Supply Annual 1992, DOE/EIA-0340(92)/1 (Washington, DC, May 1993), p. 106.

berr-McGee, News Release, August 8, 1995, p. 1.

'Energy Information Administration, Petroleum Supply Annual 1994, DOE/EIA-0340(94)/1 (Washington, DC, May 1995), p. 108; and Energy Information Administration, Petroleum Supply Annual 1993, DOE/EIA-0340(93)/1 (Washington, DC, June 1994), p. 110.

"More Trouble in Western Europe," Petroleum Economist (September 1995), p. 3.

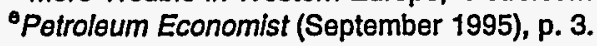

\footnotetext{
${ }^{58}$ Energy Information Administration, Form EIA-28.

${ }^{59}$ Amerada Hess Corporation, Securities and Exchange Commission Form 10-K 1994, p. 2.

${ }^{60}$ Energy Information Administration, Petroleum Supply Annual 1994, DOE/EIA-0340(94)/1 (Washington, DC, May 1995), pp. 108-111; and Petroleum Supply Annual 1993, DOE/EIA-0340(93)/1 (Washington, DC, June 1994), pp. 110-113.
} 
Despite reductions in refinery capacity, FRS company capital budgets for U.S. refining, at $\$ 4.2$ billion (Table 21), remained high, although not as high as the record $\$ 5.1$ billion spent in $1992 .^{61}$ Even though the FRS companies have been reducing capacity, a growing share of recent years' capital spending has been directed towards refinery upgrades, as the need to comply with ever stricter environmental requirements continued to account for a large share of FRS company downstream investment.

Since the early 1970 's, a series of environmental laws and regulations have had major impacts on the petroleum refining industry. Most of these laws and regulations originate from the Clean Air Act of 1970 (CAA70) and amendments to it. In 1990, the Clean Air Act Amendments (CAAA90) were passed into law, presenting the U.S. refining industry with a series of added requirements to be met through the year 2000 . low sulfur diesel fuels. The latest requirement, that refiners produce reformulated gasoline (RFG), went into effect on January 1, 1995, a development which meant that during 1994 refiners were gearing up for its production. In 1994, the early rollout of reformulated gasoline (RFG) seemed to have also played a role in the deterioration of downstream margins and earnings-particularly in the fourth quarter. Substantial RFG supplies were introduced at the gasoline pump in the latter part of the year, and several companies reported lower earnings due to its introduction. Consumer resistance to the higher pump prices of RFG and the withdrawal of several compliance regions which had earlier opted into the reformulated gasoline program made recouping the estimated 4-6 cents per gallon costs associated with the new gasoline difficult. ${ }^{62}$ All Pennsylvania counties (other than in the Philadelphia region, where RFG was required) withdrew from the program, along with several counties in New York and Maine.

By November of 1992, refiners were required to produce oxygenated gasolines and, as of October of 1993,

Table 21. Refining and Marketing Investment and Operating Data for FRS Companies, 1993-1994

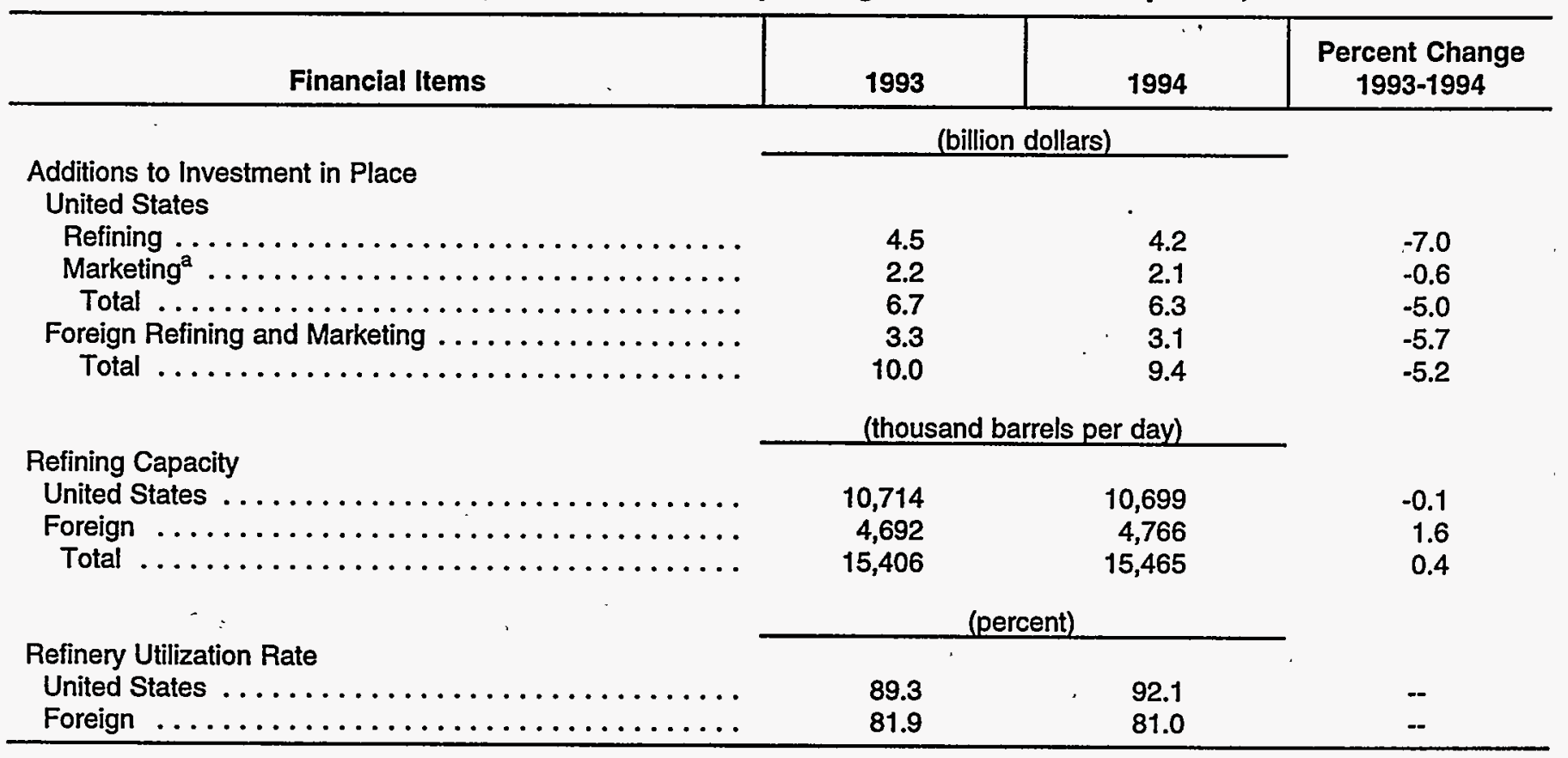

a Includes refining and marketing transport.

$--=$ Not meaningful.

Note: Sum of components may not equal total due to independent rounding. Percent changes were calculated from unrounded data.

Source: Energy Information Administration, Form EIA-28.

\footnotetext{
${ }^{61}$ Energy Information Administration, Performance Profiles of Major Energy Producers 1993, DOE/EIA-0206(93) (Washington, DC, January 1995), Table 20.

${ }^{62}$ Energy Information Administration, U.S. Energy Industry Financial Developments 1994 Fourth Quarter, DOE/EIA-0543(94/4Q) (Washington, DC, April 1995), p. 15.
} 
For the FRS companies, environmentally-related capital expenditures peaked at $\$ 1.9$ billion in $1992^{63}$ and fell slightly in 1993, the last year for which data are available. ${ }^{64}$ Still, in 1993, these expenditures accounted for over 40 percent of total FRS company refining capital expenditures (Figure 20). As a consequence, the capital intensity of FRS companies' U.S. refineries has grown considerably. In 1994, the value of FRS companies' net property plant and equipment (PP\&E) per daily barrel of crude oil refined was $\$ 2,833$ versus $\$ 2,604$ in 1993 (Figure 21). This may, in part, account for the ability of the FRS companies to achieve a record capacity utilization level in 1994, in excess of 90 percent (Table 21). ${ }^{65}$ Much of the additional refinery investment in recent years has been associated with reducing the sulfur content of diesel fuels as mandated by CAAA90. For the 74 FRS refineries in operation in 1994, nearly $200,000 \mathrm{~b} / \mathrm{d}$ of hydrotreating and hydrorefining units have been added over the last five years. ${ }^{66}$ In contrast, conversion capacity has remained fairly stable. ${ }^{67}$

\section{Figure 20. U.S. Refining Pollution Abatement Costs as a Share of Costs and Expenditures for the FRS Companies, 1977-1993}

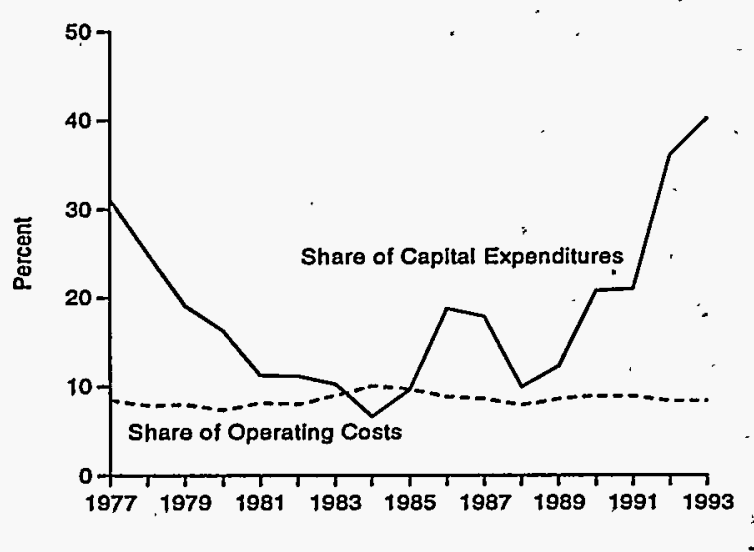

Source: U.S. Department of Commerce, Bureau of the Census, Current Industrial Reports, Pollution Abatement Costs and Expenditures (various issues) (Washington, DC).
For several years, refinery investment was also needed to accommodate a deterioration in the quality of crude oil inputs (i.e., higher gravity, higher sulfur content). However, over the last couple of years, there has seen a slight improvement in the quality of crude oil inputs to refineries (Figures 22 and 23). This may be why the spread between high and low sulfur crude oil input prices narrowed between 1993 and $1994 .{ }^{68}$ However, as the FRS company refineries have greater capacities to handle high sulfur and heavier crudes, this may have contributed to the depressed level of FRS refining margins. in 1993 and 1994.

\section{Foreign Refining}

Due to an increase in sales volumes in 1994, revenues from the FRS companies' foreign refining/marketing operations increased 2 percent, despite generally falling refined product prices. However, net income deteriorated substantially from net income in 1993, due largely

\section{Figure 21. Net PP\&E per Unit of Refinery Capacity for FRS Companies, 1974-1994}

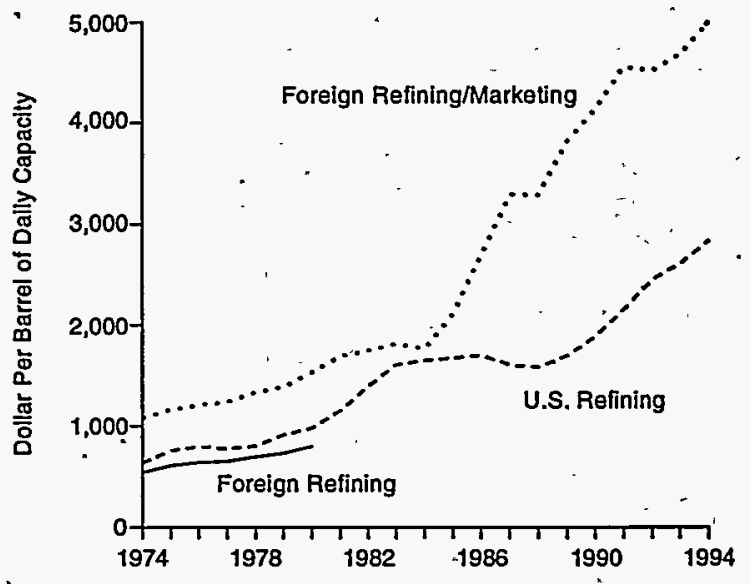

Note: Foreign refining data are not separately available from marketing data after 1980.

. Source: Energy Information Administration, Form EIA-28.

\footnotetext{
${ }^{63}$ Energy Information Administration, Performance Profiles of Major Energy Producers 1993, DOE/EIA-0206(93) (Washington, DC, January 1995), Figure 37.

${ }^{61} 1994$ data should be available in the U.S. Department of Commerce's Current Industrial Reports MA200(94)-1. The 1993 version of this report was released in December of 1994.

${ }^{65} \mathrm{An}$ alternative possibility is that refineries have experienced some amount of "capacity creep" in recent years. As no new refineries have been built for several years, petroleum companies may have understated the impact of incremental debottle-necking expansions. See: "More Trouble in Western Europe," Petroleum Economist (September 1995), p. 4.

66"World Crude Capacity Stays Flat While Conversion Capability Rise Again," Oil \& Gas Journal (December 20, 1993), pp. 37-106; and "World Crude Capacity, Conversion Capability Inch Upward," Oil \& Gas Journal (December 19, 1994), pp. $45-103$.

${ }^{67}$ Oil \& Gas Journal (December 20, 1993), pp. 37-106; and Oil \& Gas Journal (December 19, 1994), pp. 45-103.

${ }^{68}$ Petroleum Marketing Intelligence, various issues, 1993 through 1995.
} 
Figure 22. Gravity of Crude Oil Inputs to U.S. Refineries, 1981-1994

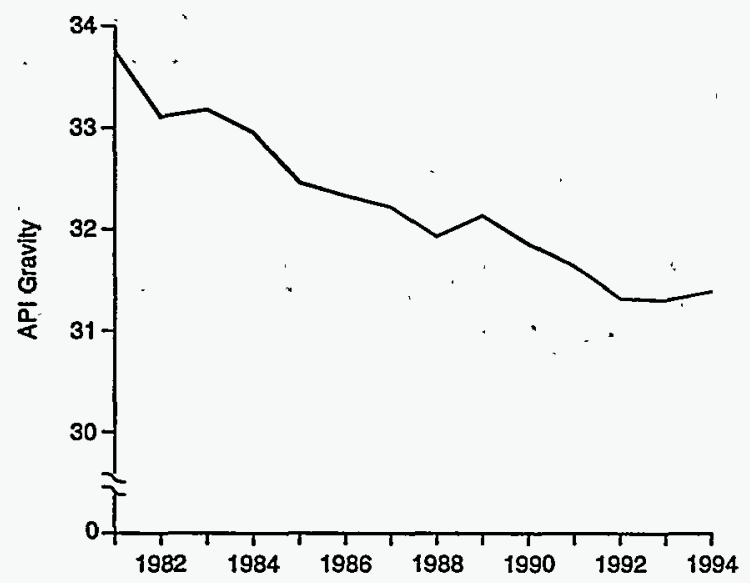

Source: Energy Information Administration, Petroleum Supply Annual, Volume 1, DOE/EIA-0340 (Washington, DC), Table 16 of various issues.

to lower overseas refined product margins. In 1994, refined product margins were lower in Europe and Asia, the main regions of the FRS companies foreign refining and marketing investments (Figure 24).

Most of the increase in sales volume occurred in the Far East, where both economic growth rates and rates of refined product consumption have far exceeded those in other regions. Excluding Japan, which has experienced several years of unusual economic difficulty, refined product consumption in the Far East has grown by more than a third in just the past five years. ${ }^{69} \mathrm{By}$ contrast, over the same period, refined product consumption has grown slowly or has remained stagnant in the more mature markets of both North America and Europe. North American and European product demand has changed little despite several years of economic expansion in the United States and in Canada and the onset of economic recovery in Europe. As a consequence, the Far East has clearly established itself as the world's second largest refined product market (Figure 25). Recently, Latin American economies have begun to grow again, and between 1990 and 1994, Latin American refined product consumption rose 13 percent. (For a more detailed review on recent FRS company activity in Latin America, see Chapter 6.)
Figure 23. Average Sulfur Content of Crude Oil Inputs to U.S. Refineries.1981-1994

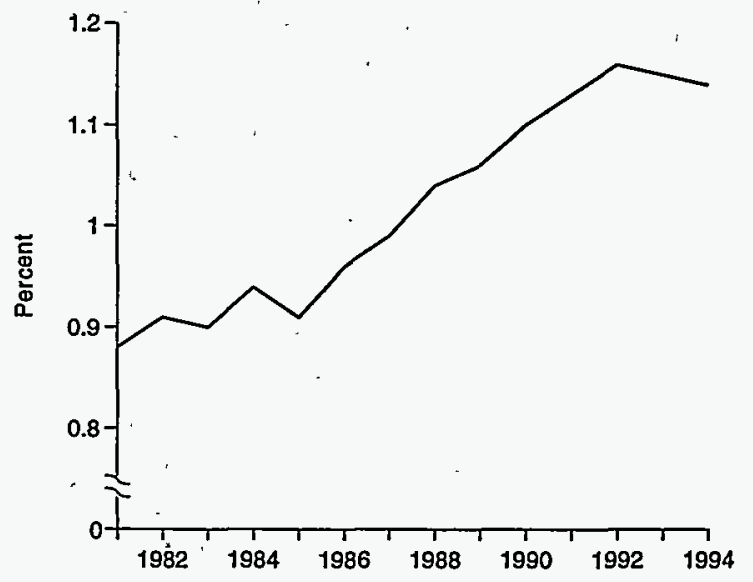

Source: Energy Information Administration, Petroleum Supply Annual, Volume 1, DOE/EIA-0340 (Washington, DC), Table 16 of various issues.

\section{Vibrant Asian/Pacific Economies Attract FRS Refining Investment}

Due to its higher growth rates, the Far East has become a growing target of the FRS companies' foreign refining/marketing investment. While over the past five years the FRS companies have increased their European refining capacity only marginally, they have expanded their capacity in the Far East by 18 percent, an amount roughly equal to nine-tenths of FRS companies' European capacity in $1994 .^{70}$

In future years, the Far East will continue to be the most important target of world downstream investments. Between now and 2005, oil consumption in Asia (excluding Japan) is expected to increase by more than 70 percent, an amount which represents over 40 percent of the increase in total global crude oil demand. ${ }^{71}$ It is estimated that Asia currently accounts for 54 percent of the world's total planned refinery expansions.? ${ }^{72}$ Of the world's 20 planned new refineries, 19 are expected to be built in Asia. ${ }^{73}$ In addition to increases in overall refined product demand, a changing demand composition towards the consumption of higher-end refined products - particularly transportation fuels-means that

\footnotetext{
${ }^{69}$ British Petroleum, Statistical Revieww of World Energy (London, June 1995), p. 10.

${ }^{70}$ Chevron Corporation, Supplement to the 1994 Annual Report; E.I. du Pont de Nemours and Company; DuPont Data Book 1994; Exxon Corporation, Financial and Operating Review 1994; Mobil Corporation, 1994 Fact Book, and Texaco Inc., Financial and Operational Supplement,
} 1994.

${ }^{{ }^{n}}$ Energy Information Administration, International Energy Outlook 1995, DOE/EIA-0484(95) (Wáshington DC, June 1995$)$, p. 79.

72"Still too Many Refineries in Europe," Petroleum Economist (September 1995), p. 2.

${ }^{73}$ Petroleum Economist (September 1995), p. 2. 
Figure 24. Foreign Refining Margins, 1991-1994

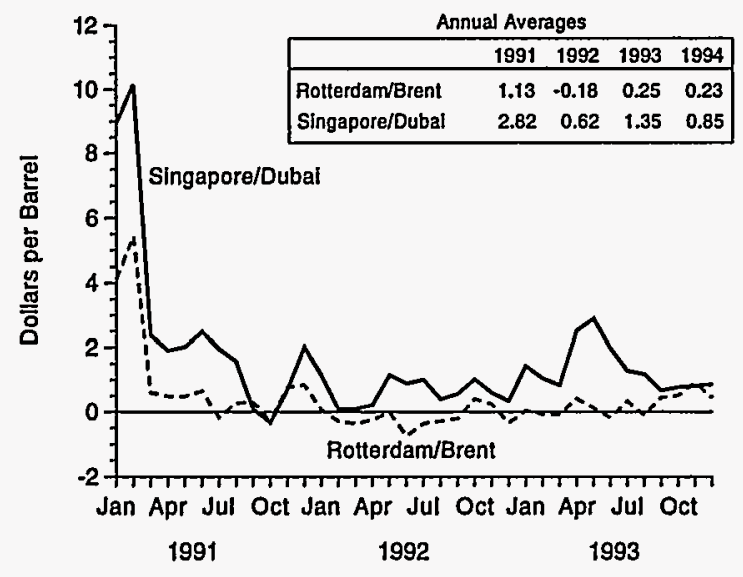

Note: Refining margin is defined as netback crude oil price less spot crude oil price. Netback price is calculated by multiplying the spot price of each refined product by its percentage share in the yield of a barrel of crude oil. Transport and out-of-pocket refining costs are then subtracted to arrive at netback price.

Source: Petroleum Market Intelligence, September 6, 1991, p. 8; April 2, 1992, p. 8; January 7, 1993, p. 8; January 6, 1994, p. 8; and January 5, 1995, p. 8.

Asian refineries will have to increase their cracking capacity significantly. Environmentally-related investments will also grow substantially. Many Asian nations are expected to reduce or eliminate lead in gasoline. Lead phase-down in gasoline is currently underway in Australia, Malaysia, New Zealand, Singapore, South Korea, Taiwan, and Thailand. ${ }^{74}$

Asia's surging demand for refined products will require substantial investment. ${ }^{75}$ In 1994, the FRS companies reported several projects intended to upgrade or expand their refining operations in the Far East:

- ARCO acquired a 9.9-percent interest in China's Zhenhai refinery. ${ }^{76}$

- Chevron reported that its Caltex subsidiary-a 50/50 joint venture with Texaco-plans to spend
Figure 25. World Petroleum Consumption, by Region, 1990 and 1994

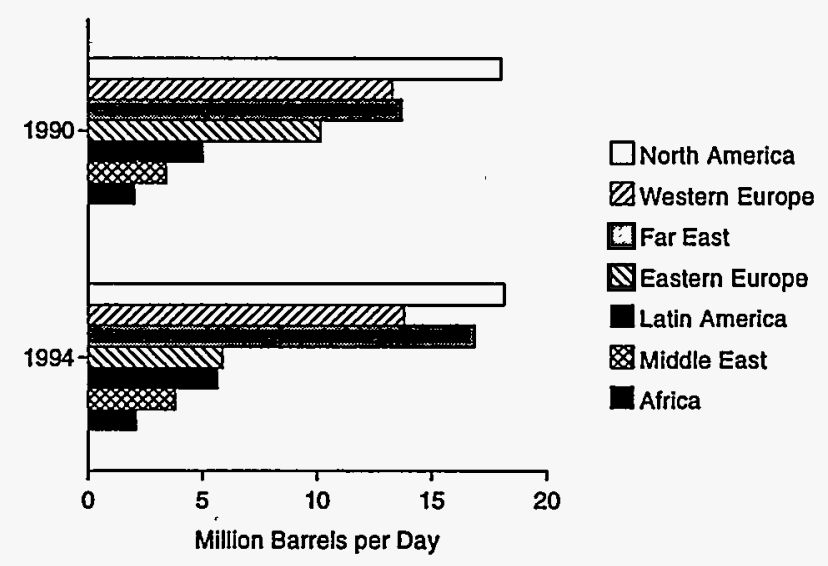

Source: British Petroleum Company, p.l.c., BP Statistical Review of World Energy (London, June 1995).

$\$ 8$ billion over the next five years in high-growth Asia. ${ }^{\pi}$ Currently, the joint venture is building a $130,000 \mathrm{~b} / \mathrm{d}$ refinery in Thailand and is upgrading a refinery in Singapore. ${ }^{78}$ In 1994, Caltex opened gasoline service stations in China. By 1997, the company intends to add $115,000 \mathrm{~b} / \mathrm{d}$ in capacity to its Batangas, Philippines, refinery. ${ }^{79}$ Caltex is also expanding its refinery in Korea. ${ }^{80}$ It is the only western company with refinery operations in South Korea. ${ }^{81}$

- DuPont's petroleum subsidiary, Conoco, signed an agreement for a joint venture with Petronas, the Malaysian national oil company, to construct and operate a 100,000 b/d refinery, which will be completed in 1997. DuPont opened 27 retail gasoline outlets in Thailand and expects to add new stations at a rate of up to 25 per year. DuPont stated in its 1994 Annual Report that Conoco expects the Asia-Pacific market will be a major region for its downstream business. ${ }^{82}$

- Exxon reported that in 1994 the company completed an expansion of its Srircha, Thailand, refinery and is currently upgrading its refineries

71"Global Refining Industry Preparing for the Future," Oil and Gas Journal (April 10, 1995), p. 52.

${ }^{75}$ One estimate is that a sum of $\$ 140$ billion will be needed to build new Asian refining capacity by 2010. See: Oil and Gas Journal (April 10, 1995).

${ }_{76}$ ARCO 1994 Annual Report, p. 5.

"Chevron Corporation, Supplement to the Cheoron Corporation 1994 Annual Report, p. 43.

${ }^{78}$ Supplement to the Chevron Corporation 1994 Annual Report, p. 43

7y"Still too Many Refineries in Europe," Petroleum Economist (September 1995), p. 3.

80" Chevron Outlines Ambitious Financial Initiative," Oil \& Gas Journal (February 7, 1994), p. 32.

${ }^{81}$ Supplement to the Chevron Corporation 1994 Annual Report, p. 43.

${ }^{82}$ DuPont, 1994 Annual Report, p. 24. 
in Japan and Singapore. Exxon intends to complete an expansion of its Port Dickson refinery in Malaysia in 1995. In 1994, Exxon expanded its retail gasoline marketing network in Thailand by 30 stations, to 800 in total. ${ }^{83}$

- Mobil reported that in the last few years its downstream focus has shifted to the Pacific Rim. ${ }^{84}$ In 1994, Mobil's product sales to Southeast Asia increased by 20 percent. In 1994, Mobil began construction of a \$180-million lubricant refinery in Adelaide, Australia, and underwent major upgrading operations at refineries in Singapore and Japan. ${ }^{85}$

- Texaco reported that its 1995 capital expenditures "will emphasize high growth areas around the world. The 1995 program includes expanding our presence. in the Pacific Rim through Texaco's affiliate, Caltex.... ${ }^{\prime 86}$

In contrast to Asia, little in the way of refinery expansion is expected to take place. in Europe in the near future. In 1994, European refinery capacity was virtually unchanged from that of the prior year. ${ }^{87}$ Further, the growing integration of refined product markets in Western and Eastern Europe could result in some downstream consolidation. In 1994, Mobil announced that it would close its refinery in Woerth; Germany, ${ }^{88}$ and in 1994 Texaco sold its Swedish retail outlets. ${ }^{89}$ There were, however, some notable FRS investments in European refining. Exxon completed a $36,000 \mathrm{~b} / \mathrm{d}$-hydrocracker at its Rotterdam facility and-a hydrorefiner at its Slagen, Norway, facility. ${ }^{90}$ Texaco completed construction of an MTBE plant at its Rotterdam refinery. ${ }^{11}$ Mobil announced a major modernization of existing production at the Mobil Oil Francaise lubricant blending facility in Gravenchon, France. ${ }^{92}$
One potential area of future growth in Europe lies in the Eastern half of the continent. In both Eastern Europe and the FSU, the recent demise of communism and welcoming of foreign investment have opened up substantial opportunities for the FRS companies in down stream investment. Countries in Eastern Europe and the FSU represent a new frontier, particularly for FRS company gasoline marketing investment. Recently, both DuPont and Exxon have reported building retail gasoline networks in several Eastern European nations. ${ }^{93}$

\section{Gasoline Marketing}

Gasoline marketing in 1994 was marked by cost reduction efforts and expansion into newly opened areas. Domestic cost-cutting efforts were notably successful during 1994, as marketing expense was reduced 38 cents (17 percent) per barrel compared to marketing expense in 1993 (Table 22). The smallest companies made the largest reduction in marketing expense, buit each company group attained lower marketing expenses. The reduction in marketing expense continues a three-year trend, having fallen 90 cents, or by 33 percent, over that period. ${ }^{94}$

At least three developments can be associated with lower marketing costs: reorganization and consolidation of marketing territory, expanded installation of pump card readers, and introduction of multiple format stations.

Consolidation of marketing territory continued during 1994. Overall, the FRS companies reduced the number of their retail outlets by more than 3,000 stations, but increased average outlet volume by 5 percent (Table 23). Among the companies that consolidated during 1994 was. BP America, which sold its California retailing network to Tosco Corp., a refining company. ${ }^{95}$

\footnotetext{
${ }^{83}$ Exxon Corporation, Financial and Operating Review 1994, p. 50.

. ${ }^{84}$ Mobil Corporation, 1994 Fact Book, p. 2.

${ }^{85}$ Mobil Corporation, 1994 Fact Book, p. 3.

${ }^{86}$ Texaco Inc., Annual Report, 1994, p. 35

87"World Crude Capacity Stays Flat While Conversion Capability Rise Again," Oil \& Gas Journal (December 20, 1993), pp. 37-106; and

"World Crude Capacity, Conversion Capability Inch Upward," Oil \& Gas Journal (December 19, 1994), pp. 45-103.

${ }^{83}$ Mobil Corporation News Release for the Financial Community, May 19, 1994.

'Texaco Inc., Annual Report 1994, p. 19.

${ }^{90}$ Exxon Corporation, Financial and Operating Review 1994, p. 52.

${ }^{91}$ Texaco Inc., Annual Report 1994, p. 19.

${ }^{92}$ Mobil Corporation News Release for the Financial Community, May 19, 1994.

${ }^{93}$ DuPont 1994, Annual Report; p. 23; and Exxon Corporation, Financial and Operating Review 1994,p. 52.

${ }^{94}$ Energy Information Administration, Performance Profiles of Major Energy Producers 1993, DOE/EIA-206(93) (Washington, DC, January 1995), Table 19, and Form EIA-28.

${ }^{95}$ The British Petroleum Company, p.l.c., 1994 Annual Report on Form 20-F, p. 17.
} 
Table 22. Marketing Characteristics and Refined Product Margin for FRS Companies Ranked by Total Energy Assets, 1993-1994

\begin{tabular}{c|c|c|c|c|c|c}
\hline & \multicolumn{2}{|c|}{$\begin{array}{c}\text { Average Outlet Volume } \\
\text { (thousand gallons } \\
\text { per month) }\end{array}$} & \multicolumn{2}{c|}{$\begin{array}{c}\text { Refined Product Margin } \\
\text { Per Barrel } \\
\text { (dollars per barrel) }\end{array}$} & \multicolumn{2}{|c}{$\begin{array}{c}\text { Marketing Expenses } \\
\text { Per Barrel } \\
\text { (dollars per barrel) }\end{array}$} \\
\cline { 2 - 7 } Group & 1993 & 1994 & 1993 & 1994 & 1993 & 1994 \\
\hline Top Four $\ldots \ldots \ldots \ldots \ldots$ & 87.6 & 90.8 & 0.67 & 0.77 & 2.08 & 1.85 \\
Five Through Twelve ..... & 116.7 & 119.8 & 0.83 & 0.59 & 2.61 & 2.23 \\
All Other ............ & 54.5 & 59.5 & 0.58 & 0.82 & 1.66 & 1.11 \\
All FRS ........... & 85.8 & 90.0 & 0.71 & 0.71 & 2.18 & 1.80 \\
\hline
\end{tabular}

Source: Energy Information Administration, Form EIA-28.

Table 23. Gasoline Distribution by FRS Companies, 1993-1994

\begin{tabular}{|c|c|c|c|}
\hline Distribution Category & 1993 & 1994 & $\begin{array}{c}\text { Percent Change } \\
1993-1994\end{array}$ \\
\hline & \multicolumn{2}{|c|}{ (million barrels) } & \\
\hline Wholesale Volume $\ldots \ldots \ldots \ldots \ldots \ldots \ldots$ & $1,011.8$ & $1,064.3$ & 5.2 \\
\hline \multicolumn{4}{|l|}{ Retail Volume } \\
\hline Dealer Volume $\ldots \ldots \ldots \ldots \ldots \ldots \ldots \ldots$ & 731.2 & 732.3 & 0.1 \\
\hline Company-Operated Volume $\ldots \ldots \ldots \ldots$ & 341.7 & 308.3 & -9.8 \\
\hline Total Retail Volume $\ldots \ldots \ldots \ldots \ldots \ldots$ & $1,072.9$ & $1,040.6$ & -3.0 \\
\hline Direct Volume....$\ldots \ldots \ldots \ldots \ldots$ & 233.4 & 232.8 & -0.2 \\
\hline Intersegment Volume $\ldots \ldots \ldots \ldots \ldots \ldots \ldots$ & 9.3 & 9.2 & -1.4 \\
\hline \multirow[t]{2}{*}{ Total volume $\ldots$} & $2,327.4$ & $2,346.8$ & 0.8 \\
\hline & \multicolumn{2}{|c|}{ (number of outlets) } & \\
\hline Dealer Outlets $\ldots \ldots \ldots \ldots \ldots \ldots \ldots \ldots$ & 34,676 & 31,705 & -8.6 \\
\hline Company-Operated Outlets .......... & 9,021 & 8,755 & -2.9 \\
\hline \multirow[t]{2}{*}{ Total Retail Outlets $\ldots \ldots \ldots \ldots \ldots \ldots$} & 43,697 & 40,460 & -7.4 \\
\hline & \multicolumn{2}{|c|}{ (thousand gallons per month) } & ' \\
\hline \multicolumn{4}{|l|}{ Average Monthly Outlet Volume } \\
\hline Dealers $\ldots \ldots \ldots \ldots \ldots \ldots \ldots \ldots \ldots$ & 73.8 & 80.8 . & 9.5 \\
\hline Company Operated..$\ldots \ldots \ldots \ldots \ldots$ & 132.6 & 123.3 & -7.0 \\
\hline All Retail $\ldots \ldots \ldots \ldots \ldots \ldots \ldots$ & 85.8 & 90.0 & 4.7 \\
\hline
\end{tabular}

Note: Percent changes were calculated from unrounded data.

Source: Energy Information Administration, Form EIA-28.

Additionally, Ashland, Exxon, Fina, Mobil and Unocal phased out selected retailing operations, with some companies indicating that the outlets had been sold to distributors. ${ }^{96}$ Amoco, ARCO, Fina, and Mobil indicated that they had reorganized their marketing operations along geographic lines."7

\footnotetext{
${ }^{26}$ Ashland Oil Inc., 1994 Annual Report, p. 36; Exxon Corporation, 1994 Annual Report, p. 4; Fina Inc., Annual Report 1994, p. 4; Mobil Corporation, 1994 Mobil Fact Book, p. 50; and Unocal Corporation, 1994 Annual Report, p. 23.

${ }^{97}$ Amoco Corporation, 1994 Annual Report, p. 18; Fina Inc., 1994 Annual Report, p. 3; Mobil Corporation, Annual Report 1994, p. 11; and National Petroleum News (August 1994), p. 8.
} 
Pump card readers are a recently-introduced innovation that became more widespread during 1994. According to 1994 financial disclosures, several companies increased their number of readers. ${ }^{98}$ Card readers allow a customer to pay for gasoline purchases at the gasoline pump, thereby reducing the amount of time required to purchase gasoline while also reducing the congestion inside the store and increasing sales. ${ }^{99}$
One of the latest developments in gasoline marketing is the multiple format station. This type of outlet has another business, often a fast food franchise, sharing the building in which the gasoline retail outlet (usually a convenience store) is located. Amoco, Ashland, BP America, Chevron, Exxon, Texaco, Unocal, and USX either introduced or noted their interest in this type of station format during $1994 .{ }^{100}$,

\section{Natural Gas Carriage and Sales}

Prior to 1984, interstate natural gas pipeline carriage shares (the transportation of natural gas by a pipeline as a separate service for a fee) were almost negligible when the industry operated in a regulated market under the Federal Energy Regulatory Commission (FERC). The FERC regulated the interstate natural gas transportation rates and natural gas prices at the wellhead. However, due to inefficiencies in the market (for example, natural gas shortages in the 1970's), FERC gradually ended the scope of regulatory control over natural gas prices after passage of the National Gas Policy Act of 1978 (NGPA)..$^{b}$ In addition, FERC issued a series of regulatory orders to allow the natural gas industry for the most part to be driven in a competitive market.

In 1985, FERC issued Order 436 that mandated interstate natural gas pipeline companies to separate their services by guaranteeing that consumers wishing to buy directly from producers have open access to transportation services on a nondiscriminatory basis. Consequently, in 1986 carriage shares delivered to the market increased 37 percent and, by 1988, they had exceeded sales volumes (natural gas that is purchased, sold, and transported by a pipeline to distribution companies and end-users) by 63 percent. ${ }^{b}$ However, Order 436 did not fully achieve the goal of establishing a nondiscriminatory and competitive environment for natural gas customers. Although natural gas pipeline companies offered customers separate transportation and sales services, the FERC believed that transportation services offered to non-sales customers were inferior to those services offered to the customers who purchased bundled services. Thus, in 1992, the FERC issued Order 636. Order 636 mandated natural gas pipeline companies to further unbundle their sales, transportation, and storage services so that all industry players have reasonable access to national supplies and markets. ${ }^{c}$ Accordingly, in 1994 , carriage shares for the interstate natural gas industry rose again, accounting for 98.5 percent of the natural gas delivered for the market, as the interstate natural gas pipeline companies operated under Order 636 for the first full year. The FRS companies' aggregate direct sales by pipelines in 1994 totalled 38 deliveries to market compared to 368 deliveries in 1993, representing a 90-percent drop in sales. ${ }^{d}$

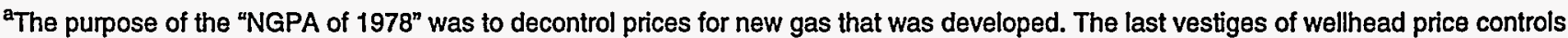
on natural gas was under the "Natural Gas Wellhead Decontrol Act of 1989," which lifted the remainder of price controls on natural gas on January 1, 1993.

bIterstate Natural Gas Association of America, Rate and Policy Analysis Department, Gas Transportation Through 1994 (Washington, DC, August 1995), Table A-1.

'Federal Energy Regulatory Commission, Order No. 636, Final Rule; 18 CFR Part 284 (April 8, 1992), pp. 28-48.

'Enron Corp., 1994 Securities and Exchange Commission Form 10-K, p. 32; Occidental Petroleum Corp., 1994 Form 10-K, p. 8; and Coastal Corp., 1994 Form 10-K, pp. 3-4.
}

\footnotetext{
${ }^{98}$ Amoco Corporation, Form-10K, p. 13; Ashland Oil, Inc., 1994 Annual Report, p. 21; Chevron Corporation, 1994 Annual Report, pp. 6-7; Exxon Corporation, 1994 Annual Report, p. 15; Mobil Corporation, 1994 Mobil Fact Book, p. 50; Sun Company, Form 10-K, p. 4; and Unocal Corporation, 1994 Annual Report, p. 18.

"99"The POS Promise: Ready to Deliver?" National Petroleum News (February 1994), pp. 30-31.

${ }^{100}$ Amoco Corporation, 1994 Annual Report, p. 18; Ashland Oil, Inc., 1994 Annual Report, p. 21; The British Petroleum Company, p.l.c., Annual Report on Form 20-F, p. 17; Chevron Corporation, 1994 Annual Report, pp. 6-7; Exxon Corporation, 1994 Annual Report, p. 15; Texaco, Inc., Annual Report 1994, p. 19; Unocal Corporation, 1994 Annual Report, P. 18; and USX Corp. Form 10-K, p. 19.
} 
Gasoline marketing in 1994 also was marked by entry and expansion of FRS company operations into emerging market economies. Five FRS companies and the Caltex joint venture of Chevron and Texaco entered or expanded their marketing operations into Eastern Europe, Asia, and Latin America during 1994. Eastern Europe was the area attracting the largest number of FRS companies, as Amoco (in the Former Soviet Union), ${ }^{101}$ DuPont (Czech Republic, eastern Germany, Hungary, and Poland), ${ }^{102}$ Exxon (Czech Republic, eastern Germany, Hungary, Poland, and Slovakia), ${ }^{103}$ and Mobil (Russia) ${ }^{104}$ all began or expanded operations during 1994, each currently operating in one or more geographic markets. Also, Texaco entered a joint venture with Norway's Norsk Hydro with the intention of later entering petroleum marketing in the Baltic States of the Former Soviet Union. ${ }^{105}$ Interestingly, refining has not been much of a target of FRS company investment in Eastern Europe. This may be due to the environmental clean-up liabilities that they might assume if they purchased Eastern European refineries. Asia also attracted interest during 1994 as Amoco (China), ${ }^{106}$ Caltex (Cambodia, China, India, Laos, and Vietnam), ${ }^{107}$ DuPont (India, Malaysia, Thailand, and Vietnam), ${ }^{108}$ and Exxon ${ }^{109}$. focused their efforts on opening or broadening operations there. Additionally, Latin America drew the attention of Amoco (Mexico) $^{110}$ and Mobil (Argentina, Ecuador, Peru, and Venezuela). ${ }^{111}$ However, the move to expand marketing efforts overseas has not been uniform. For instance, in December of 1993, ARCO sold its Brazilian marketing operations. ${ }^{112}$

\section{Transportation}

\section{Natural Gas Pipelines' Revenues Decline}

Although most of the FRS companies are involved in liquids pipelines operations, three companies (Coastal, Enron, and Occidental) are dominant in natural gas pipeline activity. These three companies are responsible for two-thirds of the total pipeline assets of the FRS companies and accounted for 17 percent of total U.S. natural gas transmission volumes. ${ }^{113}$

The transition to deregulation within the U.S. interstate natural gas pipeline industry, which began over a decade ago, moved closer to completion in 1994. The year 1994 marked the first full year that the interstate natural gas pipeline industry operated under Federal Energy Regulatory Commission (FERC) Order 636. In April 1992, FERC issued Order 636, known as the "Restructuring Rule." Order 636 requires pipelines to "unbundle" natural gas transportation services by offering transportation, sales, and storage services separately. ${ }^{114}$ The implementation of open access has fundamentally altered the way natural gas is sold, transported, and stored in the United States. Interstate pipelines now provide a variety of gas transportation and storage services. The sale of natural gas to local distribution companies and end-users has shifted to producers and nonregulated marketing companies, including interstate pipeline company affiliates. Pipeline open access, wellhead deregulation, and restructuring under Order 636 have resulted in a more competitive, market-driven industry. Thus, profits realized by the natural gas pipeline companies through the sale of gas have almost disappeared as gas is now sold by other players in the market.

Accordingly, the financial results for natural gas pipelines declined between 1993 and 1994, as the FRS companies operated in their first full year under Order 636. Revenues in 1994 were $\$ 5.6$ billion, 18 percent below revenues in 1993 (Table 24). Transportation revenue declined 4 percent, reflecting the effect of unbundled services on revenue, specifically on sales volumes of the interstate natural gas pipeline system (see the box entitled "Natural Gas Carriage and Sales" on page 42). Operating income (excluding unusual items) fell 14 percent.

\footnotetext{
${ }^{101}$ Amoco Corporation, 1994 Annual Report, p. 7.

${ }^{102}$ E.I. DuPont de Nemours and Co., 1994 Annual Report, p. 23.

${ }^{103}$ Exxon Corporation, 1994 Annual Report, p. 14.

${ }^{104}$ Mobil Corporation, Annual Report 1994, p. 12.

${ }^{105}$ Texaco Inc., Annual Report 1994, p. 19.

${ }^{106}$ Amoco Corporation, 1994 Annual Report, p. 7.

${ }^{107}$ Chevron Corporation, Supplement to 1994 Annual Report, p. 49, and Texaco Inc., Annual Report 1994, p. 19.

${ }^{108}$ E.I. DuPont de Nemours and Co., 1994 Annual Report, p. 11.

${ }^{109}$ Exxon Corporation, 1994 Annual Report, p. 16.

${ }^{110}$ Amoco Corporation, 1994 Annual Report, p. 7.

"Mobil Corporation, Annual Report 1994, p. 12.

${ }^{112}$ ARCO, 1994 Annual Report, p. 19.

${ }^{113}$ Energy Information Administration, Natural Gas Monthly, DOE/EIA-0130(95/07) (Washington, DC, July 1995$)$, Table 11.

${ }^{114}$ Cambridge Energy Research Associates, Unfinished Business: North American Gas Strategies After Order 636, 1992 Edition (Cambridge, MA, 1992), p. 3.
} 
Table 24. Financial Items for Transportation for FRS Companies, 1993-1994

(Million Dollars)

\begin{tabular}{|c|c|c|c|}
\hline Financial Items & 1993 & 1994 & $\begin{array}{c}\text { Percent Change } \\
1993-1994 \\
\end{array}$ \\
\hline \multicolumn{4}{|l|}{ Natural Gas Pipelines ${ }^{a}$} \\
\hline Revenues ......... & 6,862 & 5,643 & -17.8 \\
\hline Operating Expenses $\ldots \ldots \ldots \ldots \ldots \ldots \ldots \ldots \ldots$ & 6,053 & 4,868 & -19.7 \\
\hline Operating Income $e^{b}$ & 809 & 694 & -14.2 \\
\hline Net Income $e^{b} \ldots$. & 534 & 513 & -3.9 \\
\hline Additions to Investment in Place ${ }^{c}$ & 391 & 499 & 27.6 \\
\hline \multicolumn{4}{|l|}{ Liquids Pipelines $^{d}$} \\
\hline Revenues ..... & 4,719 & 4,650 & -1.5 \\
\hline$\ldots \ldots \ldots \ldots \ldots \ldots \ldots \ldots$ & 3,215 & 2,926 & -9.0 \\
\hline Operating Income ${ }^{b}$ & 1,509 & 1,681 & 11.4 \\
\hline Net Income ${ }^{b} \ldots \ldots$ & 1,034 & 1,234 & 19.3 \\
\hline Additions to Investment in Place ${ }^{c}$. & 568 & 320 & -43.7 \\
\hline \multicolumn{4}{|l|}{ International Marine } \\
\hline Revenues $\ldots \ldots \ldots \ldots \ldots \ldots \ldots \ldots \ldots$ & 2,545 & 2,337 & -8.2 \\
\hline Operating Expenses $\ldots \ldots \ldots \ldots$ & 2,542 & 2,408 & -5.3 \\
\hline Operating Income $\ldots \ldots \ldots \ldots \ldots$ & 3 & -71 & -- \\
\hline Net Income .... & 21 & -33 & $\therefore$ \\
\hline Additions to Investment in Place ${ }^{c}$. & 224 & 251 & 12.1 \\
\hline
\end{tabular}

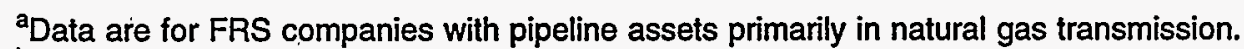

bexcludes special charges taken by FRS companies.

${ }^{\mathrm{c}}$ Measured by additions to property, plant, and equipment, plus additions to investments and advances.

${ }^{d}$ Data are for FRS companies with pipeline assets primarily in liquids pipelines.

-- = Not meaningful.

Source: Energy. Information Administration, Form EIA-28.

Despite the deterioration in financial results in 1994, the future of the FRS natural gas pipeline companies appears favorable. Increased gas consumption, stimulated by economic growth and lower gas prices, is expected to have a favorable impact on the gas transmission industry. In addition, regulatory reform, the natural gas boom, and economic growth abroad are combining to boost global opportunities for pipeline companies in the area of electric power generation.

\section{Liquids Pipelines' Revenues Decline with Alaskan Production}

Developments in the Trans Alaskan Pipeline System (TAPS), which transports crude oil from the North Slope of Alaska to the port of Valdez, Alaska, are central to the financial performance of the FRS companies' liquids pipelines. Seven of the FRS companies jointly own TAPS. ${ }^{115}$ However, three of these companies account for 92 percent of TAPS ownership (ARCO, BP America, and Exxon) ${ }^{116}$, and also account for 47 percent of the FRS companies' revenue from liquids pipelines. The Prudhoe Bay field is the nation's largest oil field and is the source for the majority of TAPS throughput. However, in 1989, the field entered its mature phase, resulting in a decline in production. To mitigate the decline and reduce operating costs, the owners of TAPS implemented two gas handling expansion programs, GHX-1 and GHX-2, during the 1990 through 1994 period, to enhance the field's oil production 117 (see the box entitled "Sustaining the Prudhoe Bay Field" on page 45).

In 1994, throughput of TAPS declined 2 percent following a 7-percent decline in $1993 .{ }^{118}$ Tariff rates rose to $\$ 3.43$ per barrel in 1994 from $\$ 2.94$ per barrel in 1993 .

\footnotetext{
${ }^{115}$ The following FRS companies together own 100 percent of the Trans Alaska Pipeline: Amerada Hess Corporation, Atlantic Richfield Corporation (ARCO), BP America, Exxon Corporation, Mobil Corporation, Phillips Petroleum Company, and Unocal Corporation. Source: Energy Alert (April 3, 1992).

${ }_{116}{ }^{\prime}$ North Slope Operators Pressing Marginal Oil Field Development," Oil and Gas Journal (May 1, 1995$)$, p. 31.

${ }^{117}$ The British Petroleum Corporation, p.I.c., 1994 BP Annual Report on Form 20-F, p. 12.

${ }^{118}$ Atlantic Richfield Corporation, 1994 Annual Report, p. 49.
} 


\section{Sustaining the Prudhoe Bay Field}

In 1990, the largest producers of Alaskan oil installed the first major gas handling system and reservoir stimulation program, GHX-1, which maintained production levels in 1990, and 1991. However, net production still declined 48,000 barrels per day (b/d) in 1992, close to the underlying natural decline rate, and $63,000 \mathrm{~b} / \mathrm{d}$ in $1993 .^{\mathrm{a}}$ In September 1993, the first phase of a second major gas handling expansion project (GHX-2). was installed, increasing gas handling capacity from 5.3 billion cubic feet per day (bcf/d) to $6.7 \mathrm{bcf} / \mathrm{d}$ in the fourth quarter of 1993. The second and final installation of the GHX-2 was completed in December 1994, increasing the field's average gas handling capacity to $7.5 \mathrm{bcf} / \mathrm{d}$. The complete GHX-2 expansion was finjshed at a total cost of $\$ 1.3$ billion. Field production is expected to increase by $100,000 \mathrm{~b} / \mathrm{d}$ in $1995 .^{\mathrm{b}}$

Although the GHX-2 system is expected to increase Prudhoe Bay's production in 1995, this increase will be offset by the field's natural decline rate of 8,000 barrels per day per year. As oil production continues to decline in Prudhoe Bay, reducing the overall North Slope production levels, the economics of maintaining the TAPS will become questionable in time. In the event that the producers of Prudhoe. Bay do not continue to develop additional fields or expand production from marginal oil fields in the North Slope, the TAPS system faces the possibility of closure. Shutting down the pipeline would effectively shut in all North Slope production, which, in 1994 , accounted for nearly 23 percent of U.S. crude oil output. ${ }^{\text {d }}$

\footnotetext{
'The British Petroleum Corporation, 1993 Arinual Report ò Form 20-F, p. 14.

${ }^{b}$ Atlantic Richfield Corporation, 1993 Annual-Report, p. 7.

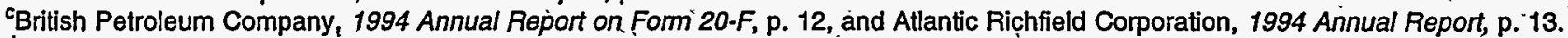

dEnergy Information Administration, Monthly Energy Review, DOE/EIA-0035(95/08) (Washington, DC, August 1995), Table 3.2a.
}

For liquids pipelines overall, revenues were down slightly (Table 24). However, operating income increased 11 percent, as costs were reduced. Additions to investment in place decreased 44 percent compared to 1993, reflecting the installation of the second major gashandling system (GHX-2) in 1993.

\section{International Marine Revenues Decline}

Weak freight rates in 1994 hampered the financial performance of international marine operations, as rates reached the lowest levels since 1978 , falling to $\$ 0.85$ per barrel in 1994 from $\$ 1.00$ in the prior year. ${ }^{119}$ Rates were adversely affected by the strong growth in oil production from the North Sea and other non-OPEC producers located close to key consuming markets. ${ }^{120}$
Also in 1994, exports from the east Mediterranean were low, reflecting the continued United Nations' embargo imposed against Iraq in $1990 .^{121}$

Revenues from international marine operations for FRS companies declined 8 percent in 1994, to $\$ 2.3$ billion, due partly to the decline in tanker freight rates. Operating income fell from $\$ 3$ million in 1993 to a loss of $\$ 71$ million in 1994 (see the box entitled "The Oil Pollution and Liability Act of $1990^{\prime \prime}$ on page 46). Oper-: ating expenses feil also, reflecting a decline in tanker activity, but not enough to offset the effect of lower freight rates (Table 24). However, revenues may improve in the future, as the tanker industry develops a new market to transport liquefied natural gas to a growing consumer base in the Far East (see the box entitled "Opportunities in LNG" in Chapter 3).

\footnotetext{
${ }^{119}$ Cambridge Energy Research Associates, World Oil Trends, 1995 Edition (Cambridge, MA, 1995), Table 34.

${ }^{120}$ The British Petroleum Company, p.l.c., BP Statistical Review of World Energy (June 1995), p. 19.

${ }^{121}$ Cambridge Energy Research Associates, World Oil Trends, 1995 Edition (Cambridge, MA, 1995), Table 33.
} 


\section{The Oil Pollution and Liability Act of 1990}

Five years after the Exxon Valdez oil spill.into the Prince William Sound, Alaska, safety-related measures emanating from this event continue to affect both the way oil is transported in U.S waters and the cost of those operations. The Oil Pollution and Liability Compensation Act of 1990 (OPA), which was enacted in response to the Exxon Valdez oil spill, requires that all newly-built tankers sailing in U.S. waters must have double-hulls by 1995. The Act also mandates a ban on all single-hull tankers from U.S. coastal waters by 2010 . Additionally, it raised the maximum limit on oil-spill liability at the Federal level, and sets no limits on liabilities States can seek. The Act also requires shippers plying U.S. waters to present evidence that they have in place credible oil spill response programs. ${ }^{a}$

Under OPA, compliance with the liability insurance of tankers to cover accidents and spills went into effect on December 28, 1994. Tankers without the new Certificate of Financial Responsibility (COFR) will not be allowed to enter the U.S. waters. The regulation required tanker owners to be insured at 10 times their prior rate, or a rate of $\$ 1,500$ per gross register ton compared to $\$ 150$ a ton in the past. Due to the financial burden of obtaining the added insurance, there were uncertainties about the availability of tankers sailing U.S. waters to import crude oil. However, enough oil tankers obtained the added insurance to avert a shortage in oil supplies. In 1994, the U.S. imported about 7.1 million barrels of oil $^{b}$ and about 80 percent of this total was transported by tanker. ${ }^{c}$ in addition, freight rates were expected to reflect a higher premium for vessels possessing the new COFR. However, the difference in rates for the two-tier market, ships entering the U.S. waters and those not entering the U.S. waters, have diminished as shipowners competed for customers. ${ }^{d}$

aU.S. Department of Energy, Transporting U.S. Oil Imports: The Impact of Oil Spill Legislation on the Tanker Market, DOE/EP/79095t-H1, (Washington, DC, June 1992), p. 91.

bEnergy Information Administration, Monthly Energy Review, DOE/EIA-0035(95/08) (Washington, DC, August 1995), Table 3.2a.

c"Threat of Disruption in Oil Supply Is Eased, "The New York Times (December 22, 1994), p. D3.

đu.S. Prices Rally, But Not For Lack Of Tanker Arrivals," Petroleum Intelligence Weekly (January 2, 1995), p. 3. 


\section{Coal and Alternative Energy}

\section{Coal}

The year 1994 appeared to represent a transition to normal market conditions for the U.S. coal industry following the United Mine Workers of America strike of 1993. During 1993, coal users (particularly electric utilities) drew down their stocks by more than 50 million tons to the lowest year-end total in 18 years. ${ }^{122}$ By the end of 1994, coal inventories were 24 million tons higher. The strong growth in U.S. coal production during 1994, up 9 percent, largely served to rebuild inventories. ${ }^{123}$ U.S. coal consumption was nearly unchanged from 1993 and coal exports continued to decline. ${ }^{124}$ Overall, U.S. coal prices, on an annual basis, fell 4 percent between 1993 and 1994. ${ }^{125}$
Despite lower coal prices in 1994, the FRS companies' income from their coal operations increased during 1994 , relative to their income in 1993, as operating cost reductions more than offset price reductions (Table 25). FRS coal revenues fell 10 percent. However, even greater declines in operating expense and general and administrative expenses resulted in a 29-percent increase in operating income.

Probably the most important element of cost reduction in the FRS companies' coal operations is application of advancing technologies. These innovations tend to improve mine productivity and safety. ${ }^{126}$ For example, longwall mining systems continue to be added (Exxon) or extended (ARCO) in underground mines. ${ }^{127}$

\section{Table 25. Coal Financial and Operating Indicators for the FRS Companies, 1993-1994} (Million Dollars)

\begin{tabular}{|c|c|c|c|}
\hline Financial and Operating Indicators & 1993 & 1994 & $\begin{array}{l}\text { Percent Change } \\
\text { 1993-1994 }\end{array}$ \\
\hline \multicolumn{4}{|l|}{ Coal Financial Indicators } \\
\hline $\begin{array}{l}\text { Coal Revenues ............................... } \\
\text { General Operating Expenses (excludes taxes }\end{array}$ & 3,063 & 2,745 & -10.4 \\
\hline and unusual items) ${ }^{a} \ldots \ldots \ldots \ldots \ldots \ldots$ & 2,166 & 1,781 & -17.8 \\
\hline Coal Production Taxes...$\ldots \ldots \ldots \ldots \ldots \ldots$ & 187 & 126 & -32.6 \\
\hline Depreciation, Depletion, and Amortization $\ldots \ldots \ldots \ldots$ & 342 & 398 & 16.4 \\
\hline General and Administrative $\ldots \ldots \ldots \ldots \ldots \ldots$ & 89 & 80 & -10.1 \\
\hline \multirow[t]{2}{*}{ Operating Income (excludes unusual items) ${ }^{\mathbf{a}}$} & 279 & 360 & 29.0 \\
\hline & \multicolumn{2}{|c|}{ (million tons) } & \\
\hline Coal Operating Indicators & & & \\
\hline Coal Production $\ldots \ldots \ldots \ldots \ldots \ldots \ldots \ldots$ & 197 & 180 & -8.6 \\
\hline 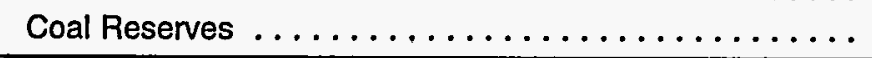 & 16,142 & 13,381 & -17.1 \\
\hline
\end{tabular}

a Unusual items totaled $\$ 65$ million (pretax) in charges and $\$ 176$ million (after tax) in gains in 1993, and $\$ 199$ million (pretax) in charges and $\$ 126$ million (after tax) in charges in 1994.

Sources: Energy Information Administration, Form EIA-28, and company annual reports for unusual items.

\footnotetext{
${ }^{122}$ Energy Information Administration, Monthly Energy Review, September 1995, DOE/EIA-0035(95/09)(Washington, DC, September 1995), Table 6.3.

${ }^{123}$ Energy Information Administration, Annual Energy Review, 1994, DOE/EIA-0384(94) (Washington, DC, July 1995), Table 7.2.

${ }^{124}$ Annual Energy Review, 1994, Tables 7.3 and 7.4.

${ }^{125}$ Annual Energy Review, 1994, Table 7.8.

${ }^{126}$ Kerr-McGee Corporation, Annual Report 1994, p. 15.

${ }^{127}$ ARCO, 1994 Annual Report, p. 13; Cyprus Amax Minerals Company, 1994 Annual Report, pp. 16-17; and Exxon Corporation, 1994 Annual Report, p. 20.
} 
Meanwhilè, surface mining operations are introducing more heavy equipment and draglines that are larger (Ashland's Arch Mineral) and computerized. ${ }^{128}$ However, implementing these technologies is costly and recovering the costs can prove difficult. ${ }^{129}$

Another strategy for reducing costs involves selective sales of coal properties. For example, Exxon sold two Wyoming surface mines during 1994..130 Similarly, USX's U.S. Steel Group began the sale of a Perinsylvania underground mine; which was expected to be completed.during early $1995{ }^{131}$ Chevron has completed the sale of its non-coal mineral assets and publicly. stated the desire to sell selected undeveloped coal properties. ${ }^{132}$

Another strategy. in the 1990's has been divestiture of coal operations by some FRS companies. Sun Company was the most recent to essentially'complete its exit. Sun sold its western coàl operations during 1993, some of its eastern-coal properties during 1994, and is looking for a buyer for the remaining eastern' coal properties. ${ }^{133}$ Sun's almostt complete exit from the domestic coal industry is the most recent of sevieral over the past five years. Six of the FRS companies with coal operations in 1989 completely exited the industry by 1994. In 1989 FRS companies produced 29 percent of U.S. coal. $^{134}$ During 1994 the remaining FRS companies accounted for 17 percent of domestic coal production. ${ }^{135}$
However, such dramatic changes may obscure the performances of continuing FRS coal producers. Table 26 presents financial and operating information for a consistent group of domestically-oriented FRS coal producers. Average revenues of these companies for 1994 fell more than 10 percent compared to 1993. However, because production increased and average operating expense was reduced by more than 12 percent, average operating income essentially held steady around $\$ 3.00$ per ton. Consequently, the continuing coal producers' profitability per ton during 1994 was essentially the same as that in 1993.

\section{Alternative Energy}

In 1994; the 'FRS companies' alternative energy investments were largely in tar sands operations, cogenèration; and geothermal'sources. These lines of activity. accounted for 93 percent of the FRS companies' alternative energy revenues in 1994. Solar power manufacturing was of lesser importance. Four companies (ARCO, Coastal, Enron, and Texaco) accounted for a large share. of FRS companies' investment in cogeneration and electric power facilities. Sun and Exxon are largely responsible for FRS investment in oil production from Canadian tar sands, while Unocal primarily accounted for the FRS companies' investment in geothermal production.

Table 26: Financial and Operating Items for Continuing FRS Coal Producers, 1993-1994 (Dollars per Ton)

\begin{tabular}{|c|c|c|c|}
\hline$\because \quad \because \quad: \cdots$ & 1993 & 1994 & $\begin{array}{c}\text { Percent Change } \\
\text { 1993-1994 }\end{array}$ \\
\hline Value per Ton Produced ${ }^{\mathrm{a}}$ & "... & & \\
\hline Revenues ... & 19.57 & 17.52 & -10.5 \\
\hline Total Operating Expense & 16.57 & 14.54 &.-12.3 \\
\hline Operating Income $\ldots \ldots$ & 3.00 & 2.98 & -0.7 \\
\hline Production (million tons) ${ }^{b}$ & 163 & 173 & 6.1 \\
\hline
\end{tabular}

axcludes Exxon and ARCO, due to the prevalence of foreign coal operations.

'Iricludes Exxon and ARCO's U.S. production and Ashland's proportionate share of 'subsidiaries' production. Includes'only continuing FRS coal producers.

Source: Energy Information Administration, Form. EIA-28.

${ }^{128}$ Ashland Oil, Inc., 1994 Annual Report, p. 30.

${ }^{129}$ Addington Resources, Inc., 1994 Annual Report, p. 6.

${ }^{130}$ Exxon Corporation, 1994 Annual Report, p. 20.

${ }^{131} U . S$. Steel Group, U.S. Steel Group Annual Report 1994, pp. 22-23.

${ }^{132}$ Chevron Corporation, 1994 Annual Report, p. 21 and Supplement to the Chevron Corporation 1994 Annual Report, p. 49.

${ }^{133}$ Sun Company, Inc., Securities and Exchange Commission Form 10-K, 1994, p. 13.

${ }^{134}$ Energy Information Administration, Performance Profiles of Major Energy Producers 1993, DOE/EIA-0206(93) (Washington, DC, January 1995), p. 39.

${ }^{135}$ FRS company information is from Energy Information Administration, Form EIA-28. U.S. coal industry information is from Energy Information Administration, Coal Industry Annual 1994, DOE/EIA-0584(94).(Washington, DC, December 1995), Table 1. 
The FRS companies with alternative energy operations showed considerable overall improvement in revenue and operating income in 1994. Financial performance benefitted from record levels of oil production from tar sands, improved performance in cogeneration, and positive operating results in geothermal power. Both Exxon and Sun reported record levels of production from tar sands, totaling 118,500 barrels per day $(b / d)$ in 1994, up 13 percent from production in $1993 .{ }^{136}$ Unocal's earnings from geothermal in 1994 increased $\$ 6$ million compared to earnings in 1993, excluding the $\$ 19$ million gain in 1993 from the sale of geothermal properties in the Imperial Valley of California. Increased geothermal earnings were due primarily to the start-up of Indonesian operations and reduced depreciation at The Geysers in northern California. ${ }^{137}$

Overall, alternative energy revenue for FRS companies increased 16 percent, to $\$ 1.3$ billion, outpacing an increase in operating expenses (Table 27). Operating income was up 24 percent in 1994, the fifth consecutive year of positive earnings. Prior to 1990, the FRS companies realized operating losses from alternative energy activities in every year since 1974. Capital expenditures declined 35 percent, to $\$ 254$ million, following a 67-percent increase in 1993. Expenditures in 1993 were unusually high due to Enron's $\$ 151$ million investment in the Teesside electric generation facility in the United Kingdom ${ }^{138}$ and Unocal's $\$ 53$ million expenditure for geothermal operations in Indonesia. ${ }^{139}$ Capital expenditures for alternative energy in 1994 were less than 1 percent of the FRS companies' total capital expenditures. However, targets of investment were frequently in rapidly growing locales and involved applications of advancing technologies.

Cogeneration, which is the simultaneous, though sometimes sequential, production of steam and electricity from a single fuel source, and electric power generation from gas-fired turbines have been sources of growth for natural gas demand. Four FRS companies. (ARCO, Coastal, Enron, and Texaco) own large shares of investments in cogeneration and electric power generation. Enron, a recent addition to the FRS group in 1992, added significantly to the companies' involvement in cogeneration facilities, making cogeneration the second largest FRS investment in alternative energy beginning in 1993. In 1994, a number of FRS companies expanded their independent power production businesses, concentrating on international opportunities primarily in the Asia-Pacific region and in Latin America. For example, Enron had new projects under development in the Dominican Republic, in China, in India, and two power projects in Indonesia plus four cogeneration projects in the United States. ${ }^{140}$ ARCO, another cogeneration investor, has partnership interests in the Watson

Table 27. Revenues, Income, and Investment in Other Energy for FRS Companies, 1993-1994 (Million Dollars)

\begin{tabular}{|c|c|c|c|}
\hline Item & 1993 & 1994 & $\begin{array}{c}\text { Percent Change } \\
\text { 1993-1994 }\end{array}$ \\
\hline \multicolumn{4}{|l|}{ Revenues and Expenses } \\
\hline Revenues......... & 1,121 & 1,296 & 15.6 \\
\hline Operating Expenses ${ }^{a}$. & 963 & 1,100 & 14.2 \\
\hline Operating Income ${ }^{\mathrm{a}} \ldots$ & 158 & 196 & 24.0 \\
\hline \multicolumn{4}{|l|}{ Additions to Investment in Place ${ }^{b}$} \\
\hline United States ....... & 34 & 77 & 126.5 \\
\hline Foreign $\ldots \ldots \ldots \ldots \ldots \ldots \ldots \ldots \ldots$ & 358 & 177 & -50.6 \\
\hline 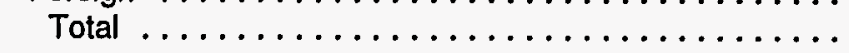 & 392 & 254 & -35.2 \\
\hline
\end{tabular}

axcludes unusual items.

${ }^{b}$ Additions to net property, plant, and equipment and advances to unconsolidated subsidiaries.

Source: Energy Information Administration, Form EIA-28.

${ }^{135}$ Exxon Corporation, 1994 Financial And Operating Review, p. 35, and Sun Company, 1994 Annual Report, p. 32.

${ }^{137}$ Unocal Corporation, 1994 Securities and Exchange Commission Form 10-K, p. 22. The sale of properties in Imperial Valley, California, only accounted for 9 percent of Unocal's geothermal energy assets.

${ }^{138}$ Enron Corporation, 1994 Annual Report, p. 39.

${ }^{139}$ Unocal Corporation, 1993 Annual Report, p. 24

${ }^{140}$ Enron Corporation, 1994 Securities and Exchange Commission Form 10-K, p. 11, and 1994 Annual Report, pp. 26-27. In 1994 Enron had four new cogeneration projects under development. These projects included a two-phase 185-megawatt power project in the Dominican Republic, a 150-megawatt Hainan Island power project in China, a two-phase 2015-megawatt project in Dabhol, India, and two power projects in Indonesia with a combined capacity of 636 megawatts. In addition, Enron has ownership interests in cogeneration facilities in the United States, and abroad in Guatemala, the United Kingdom, Germany, and in the Philippines. 
Cogeneration Company located at ARCO's Los Angeles refinery in Carson, California, which has been in operation since $1988 .{ }^{141}$ Coastal has also been active in cogeneration with projects in El Salvador and Poland ${ }^{142}$ and, through a joint venture, intends to purchase a power project in the Dominican Republic. ${ }^{143}$ Another FRS company, Texaco, has an ownership interest in nine cogeneration facilities in the United States, with a combined capacity of 1,057 megawatts. ${ }^{144}$

FRS companies have been involved in Canadian tar sands operations since the 1970's. As in other lines of activity, extraction of oil from tar sands has been a focus of cost reduction in recent years. In 1994, Sun and Exxon reported that costs of recovering oil from tar sands have fallen below $\$ 12$ a barrel, and they expect the cost to continue to drop to below $\$ 10$ per barrel within three to four years. ${ }^{145}$ Due to the continued improved performance in tar sands operations, Syncrude Canada- a consortium led by Imperial Oil, a subsidiary of Exxon, and nine other investors-signed an agreement with the Alberta government to extend Syncrude's oil sands mining plant operating license from the year 2018 to 2025 and to increase the permit production by 25 percent (or $217,000 \mathrm{~b} / \mathrm{d}$ ), an action which will significantly add to the plant's reserves. ${ }^{146}$

Unocal is the world's largest producer of geothermal power and has been in geothermal operations for more than 20 years. Unocal has U.S. operations concentrated in California and foreign operations in the Philippines and Indonesia. In the third quarter of 1994, Unocal's Gunung Salak field came on line supplying two power plants in-Java. Texaco and Chevron, through their 100percent owned subsidiary Amoseas Indonesia, are new investors in geothermal operations. In 1994, the company brought on line its first geothermal energy project located in Darajat, West Java, with a capacity of 55 megawatts. ${ }^{147}$

Commitments to solar energy by the FRS companies have been reduced in recent years. In 1990, ARCO sold off its solar power subsidiary to Siemens AG of Germany, ${ }^{148}$ leaving only Amoco and Mobil as the remaining two FRS companies with solar power manufacturing facilities. However, in 1993, Mobil shut down its 19-year old solar energy program (partly due to the expectations of slow financial growth) ${ }^{149}$ and thereafter sold the solar operation in August 1994 to ASE Americas, ${ }^{150}$ another German-based company. The exit of Mobil left Amoco as the only U.S.-based oil company invested in solar energy. However, in December 1994, Amoco and Enron signed a merger agreement to combine their operations into a new company, Amoco/ Enron Solar. The merger will be effective in 1995. Also, Enron, prior to the merger, has a proposal pending with the U.S. Department of Energy to build a new solar plant in Nevada. If approved, the plant would take up to 15 years to come fully on line. ${ }^{151}$

Some FRS companies have investment interests in the reformulated fuels market and continued investments in coal gasification projects. For example, Kerr-McGee has operations in renewable fuels, such as ethanol, at its plant in Corpus Christi, Texas. ${ }^{152}$ In addition to Texaco's investment in cogeneration, the company has investments in gasification in the United States and in Italy. ${ }^{153}$ Coastal has a coke gasification/cogeneration plant under development at its refinery in El Dorado, Kansas, and commercial operation is expected to begin in 1996. This project will capitalize on Texaco's patented gasification technology, which converts low-grade hydrocarbons, such as high sulfur coal, petroleum coke and heavy oil, into a clean synthetic gas for the production of electric power

\footnotetext{
${ }^{141}$ ARCO Public Affairs, "The Watson Cogeneration Project" (October 23, 1995), pp. 1-2.

${ }^{142}$ Coastal Corporation, 1994 Annual Report, p. 30.

${ }^{143}$ Coastal Corporation, Second Quarter Results (July 25, 1995), p.2.

${ }^{144}$ Texaco, Inc., 1993 Financial and Operational Supplement, p. 36.

145"Unlocking Oil in Canada's Tar Sands," The New York Times (December 28, 1994), p. D5.

${ }^{146}$ Exxon Corporation, 1994 Financial And Operating Review, p. 35

${ }^{147}$ Texaco Corporation, 1994 Annual Report, pp. 14-15, and 1994 Securities and Exchange Commission Form 10-K, p. 2.

${ }^{148}$ The Wall Street Journal (March 27, 1991), p. A5.

${ }^{149}$ Mobil, News Release (November 4, 1993), p. 1; and Oil and Gas Journal (November 15, 1993), p. 31.

${ }^{150} \mathrm{ASE}$, a solar energy company newly formed from a merger of two former solar energy companies, RWE, a subsidiary of Nukem, and Deutsch, a subsidiary of Daimler Benz, intends to expand solar activities considerably over the next decade. Sources: The Washington Post (August 3, 1994), p. F2., and Power Europe (August 12, 1994), Energy Section.

151"Amoco's Solarex Venture to Merge with Enron. Unit," The Sun (December 20, 1994), p. C9.

${ }^{152}$ Kerr-McGee Corporation, 1991 Annual Report, p. 25, and 1994 Securities and Exchange Commission Form 10-K, p. 22.

${ }^{153}$ Texaco, Inc., 1993 Financial and Operational Supplement, p. 36.
} 


\section{The Privatization of State Energy Companies}

This chapter reviews the range of investment opportunities presented to FRS companies that have arisen as a result of privatization of various state energy companies. In part, the roots of these privatizations lay in the globalization of the world economy and the growth in international trade and investment. Also, in part, these privatizations evolved due to the receding of communism in Eastern Europe and the Former Soviet Union (FSU) in recent years and to the growing conviction that free enterprise advances the wealth of nations better than nationalized industries and planned economies. Recent efforts by different countries to privatize state-owned industries have varied considerably. Consequently, in this chapter privatization is defined as any movement towards a market-driven economy that replaces public ownership and control with private ownership and control.

For the FRS companies, privatization may turn out to be one of the most important developments in world petroleum markets in recent times. Upstream, privatization offers opportunities to add crude oil and gas reserves of a magnitude unseen since the discovery of the North Sea and Prudhoe Bay. Downstream, FRS company investment opportunities have also grown considerably as a result of recent privatizations. In addition, opportunities in natural gas pipelines, electric power generation, and in non-petroleum energy investments have also grown considerably. To the extent that privatization and other economic reform promotes greater economic growth and with it greater energy demand, FRS companies stand to benefit from increased sales.

Recent privatization efforts have been global phenomena-occurring in countries as different as China and Colombia. However, for the FRS companies, privatization efforts in the countries of the FSU, in China, and in Latin America may prove most consequential and are discussed more extensively in this chapter. The sheer size of these regions' national petroleum industries accounts for this emphasis. Together, the FSU, China, and Latin America account for 29 percent of world crude oil production. Although the potential of these regions for the FRS companies remains enormous, China and the FSU comprise relatively newly-opened areas of exploration and development activity while in Latin America the FRS companies have been active to some degree for decades. In 1994, the FRS companies produced little crude oil in China and the FSU, while FRS companies produced 236,000 barrels per day in Latin America.

For these regions to continue to develop their petroleum resources, foreign capital will play a critical role. In part, this is due to the vast expenditures needed to meet energy development plans in coming years. For example, between now and 2000, China alone has energy investment needs that have been estimated at $\$ 300$ billion. ${ }^{154}$ Several nations have thus far raised billions of dollars through privatization. For instance, since 1989, Argentina has raised at least $\$ 20$ billion in revenue through privatization. ${ }^{155}$ Mexico has raised a similar amount through privatization of state-owned industries. ${ }^{156}$ For state petroleum companies being privatized, the FRS companies have much to offer. In addition to being sources of highly needed capital investment, FRS companies offer technological and managerial expertise, as well as access to crude oil and refined product outlets. FRS companies also offer newly-privatized companies a means of quickly adapting to the business practices of the global market economy.

Progress in privatizing state petroleum companies has been uneven across and within regions. On more than one occasion, previous progress at privatization has suffered severe setbacks. The risks attendant to forming joint ventures have been mostly political in nature. For example, billions of dollars of planned FRS investment activity in the FSU are currently on hold pending passage of a property rights law. As another instance, in August 1995, one of the state governments in India decided to pull out of a deal recently negotiated with Enron to build and operate a \$3-billion electricity generating plant. ${ }^{157}$

\footnotetext{
${ }^{154}$ D. Bamber, "Late Welcome for Foreign Funds," Petroleum Economist (June 1994), p. 9.

${ }^{155}$ B. Netzer, "As State Privatization Programs Multiple, So Do Opportunities for ADR Investors," International Herald Tribune (November 19, 1994).

${ }^{156}$ The Dallas Morning News (February 5, 1995), p. $1 \mathrm{H}$.

${ }^{157}$ The New York Times (August 4, 1995), p. D2.
} 


\section{Opportunity in the Former Soviet Union}

The breakup of the FSU and its move toward a marketdriven economy offer new exploration and production opportunities in one of the world's largest petroleumproducing areas. In no other region does the successful transformation of state-run petroleum companies into privately-owned enterprises hold out more promise for the FRS companies. In areas of the FSU where privatization's progress has been slight, the lifting of restrictions on foreign investment in petroleum has still resulted in attracting. FRS company investment dollars. However, foreign investment in petroleum operations also entails greater risks in these regions. So far, FRS companies have expressed a willingness to invest several billions of dollars to develop FSU petroleum resources. ${ }^{158}$ However, until the FSU achieves a much greater degree of political stability and economic reform, these investments 'will largely be deferred.

The breakup of the Soviet Union resulted in the creation of three substantial crude-oil-producing political entities, the Russian Federation, Kazakhstan, and Azerbaijan. In 1994, the three areas produced over 95 percent of the 7.4 million barrels per day of crude oil produced in the FSU countries. ${ }^{159}$ At 6.4 million barrels per day of crude oil production, the Russian Federation was the largest of the three producers, followed by Kazakhstan (435,000 barrels per day) and Azerbaijan (195,000 barrels per day).

Privatization in these regions holds many potential benefits for both the FSU and the FRS companies. For the FSU, privatization provides a means of obtaining badly needed foreign technology, investment capital, managerial and technical expertise, and access to global petroleum markets. The FRS companies could also become instrumental in reversing the precipitous decline in FSU crude oil production. The FSU reached its peak in 1988, when crude oil production averaged 12 million barrels per day (or 20 percent of total world production), and the FSU was the world's largest producer of crude oil. However, several years of underinvestment, artificially low prices, outdated technology and equipment, poor management, and, most recently, political turmoil, have been responsible for a five-year slide in FSU crude oil production. By 1994, FSU production of crude oil had fallen by over 4 million barrels per day.

For the FRS companies, privatization means access to a new source of reserves and new markets for equipment and technology sales. FRS companies and other foreign investors are currently negotiating over the development of an estimated 11 billion barrels in reserves in Russia alone. ${ }^{160}$ Ironically, the 1990 's are not the first time U.S. oil companies have looked to this region as a major source of future petroleum reserves. Both Standard Oil (which in one way or another was a precursor to the FRS companies Amoco, BP America, Chevron, Conoco, Exxon, Mobil, and Sun) and Royal/Dutch Shell (corporate parent of Shell Oil) had struggled for control of Russia's vast oil riches late in the last century. As Daniel Yergin noted in The Prize, "Time after time in years past, the fortunes of Russian oil have had significant global impact, beginning in the nineteenth century, when the development of an oil industry in Azerbaijan around Baku broke the global grip of Standard Oil and indeed the virtual monopoly of western Pennsylvania.."161

At present, ambitious plans to develop FSU resources have faltered largely due to uncertainties surrounding oil and gas laws, changing tax regimes, and the ability (both physically and legally) to export crude oil to international markets. Although only two FRS companies reported petroleum production in FSU countries in 1994, at least nine of the FRS companies reported exploration and development spending in FSU countries, while several more FRS companies have reported ongoing or planned projects. If economic reforms continue and political stability improves in FSU regions, the FSU could eventually rival the North Sea in its importance to the FRS companies as a source of petroleum investment, production, revenue, and income. To entice foreign capital and investment, the FSU must offer investors the opportunity to earn acceptable returns on their investments. To do so, the FSU must respect private property rights, permit access to markets, liberalize prices, and offer fair taxation. Reliable transportation and access to foreign markets are other hurdles faced by both Russian and foreign companies. Exasperation with such difficulties has led some western companies to withdraw from their FSU

\footnotetext{
${ }^{158}$ For instance, once the production-sharing law is approved in the Russian Federation, more than $\$ 60$ billion of investment could eventually flow into oil fields in the Russian Federation alone. Source: "New Oil Laws Clash," Petroleum Economist (September 1995), p. 76.

${ }^{159}$ Production data in this section are from: British Petroleum Company, BP Statistical Review of World Energy 1995, p. 5.

160"Foreign,Investors Sober Up," Petroleum Economist (April 1995), p. 3.

${ }^{161}$ D. Yergin, The Prize, The Epic Quest for Oil, Money, and Power (New York, NY: Simon \& Schuster), p. 773.
} 
investments entirely. ${ }^{162}$ Others are putting existing and future projects on hold, choosing to wait until an adequate legal structure that allows for protection of private property rights through enforcement of contracts and protection of property is in force.

\section{The Russian Federation}

Production by joint ventures has been increasing, but still they contribute only a fraction to overall FSU production. One frequently cited problem with investing in Russia is the slow progress in enacting legislation, particularly the Oil and Gas Law (which establishes the authority for production-sharing agreements) designed to clarify the uncertainty surrounding jurisdiction over resources, licensing, and taxation. Foreign companies want a stable legal framework in place to protect them from the many risks associated with investing in the region. Currently, production sharing agreements are not recognized by Russian law. What started out three years ago as promising legislation is still going through the bureaucratic process where it is currently being redrafted.

In Russia, reform of the market economy has been undergoing mass privatization under President Yeltsin's broad Presidential powers. Yeltsin's November 1992 decree set the stage to establish 10 to 12 vertically integrated oil companies from former oil producing associations of the FSU. So far, nine vertically integrated regional companies have combined production associations with refineries and marketing associations. Lukoil is the largest and it has been ranked in the top 20 largest world oil producers for the last two years.

To attract direct foreign investment, the Russian government will allow foreign acquisition of up to fifteen percent of the major Russian oil-producing companies during the second phase of privatization. ${ }^{163}$ So far, Atlantic Richfield (ARCO) is the first and only western company who announced its intention to acquire an equity stake in a Russian petroleum company. For $\$ 250$ million, it intends to secure a 6.3-percent interest in the largest vertically integrated Russian oil firm, Lukoil. ${ }^{164}$ The difficulty of maneuvering around the many legal and bureaucratic obstacles in Russia may be the incentive for ARCO to make the investment, whereby Lukoil will help guide ARCO through the maze of developing
Russia's large reserves in its effort to increase its oil reserves in exchange for ARCO's capital and technology.

There are five major areas of production in the Russian Federation, three of which have attracted the interests of the FRS companies: The Arctic Region, the Russian Far Easit, and Western Siberia.

\section{Arctic Region}

The entire Timan Pechora region within the Arctic Circle could produce about 5 to 10 billion barrels of oil, rivaling discoveries on Alaska's North Slope. Antiquated pipelines with limited capacity have international companies in the region looking at the feasibility of building an offshore terminal (costing $\$ 2$ billion) that could handle 450,000 barrels of oil per day. ${ }^{165}$

The largest production-sharing agreement in the Arctic Region being negotiated is the Timan Pechora Co. (TPC), led by Texaco ( 30 percent) and including Exxon (30 percent), Amoco (20 percent), and Norsk Hydro (20 percent). The joint venture includes the exploration and development of 1.8 million acres located in the Timan Pechora Basin (with 11 huge oil fields) north of the Arctic circle. Estimated recoverable reserves are 2 to 5 billion barrels of oil, while the total investment is estimated at $\$ 45$ billion over the expected 50-year life of the 11 area fields. ${ }^{166}$ In addition to the TPC joint venture, Texaco is also planning development of potentially huge reserves near the coast of the Barents Sea and has agreed to work alongside a Russian consortium that includes the Russian petroleum companies Lukoil, Yukos, and Rosneft. ${ }^{167}$

The first oilfield developed and brought on stream by a western company ${ }^{168}$ is the Polar Lights joint venture (with DuPont's Conoco and the Russian petroleum company Arkhangelskgeologiya) in the Arctic Region located in the Timan Pechora Basin. The joint venture expects to develop the estimated 110-million barrel Ardalin Field. Negotiations for the joint venture began in 1989 before the breakup of the Soviet Union and took five years and $\$ 369$ million in start-up costs to negotiate. The joint venture began producing oil in August 1994. Output is expected to peak at 25,000 barrels per day in 1996. Conoco has cited setbacks with its joint

\footnotetext{
${ }^{162}$ Petroleum Economist (April 1995), p. 4.

163"Russia's Lukoil Schedules Second Phase of Privatization Campaign," Oil \& Gas Journal 92 July 25, 1994$),$ p. 38.

161"Lack of Production Sharing Laws Slows Joint Ventures in Russia," Oil \& Gas Journal 93 (October 30, 1995$),$ p. 16.

${ }_{165}$ "Conoco Joint Venture Starts to Pump Oil from Russian Field," Financial Times (September 1, 1994), p. 2.

16t Texaco, 1994 Annual Report, p. 14.

167"Gas in the Former Soviet Union: A Special.Report," Petroleum Economist, Special Report, 1995, p. 68.

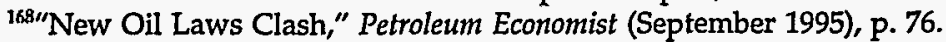


venture due to restricted access to export pipelines. ${ }^{169}$ Conoco plans future development of up to 1 billion barrels of estimated recoverable oil reserves located in larger nearby fields. ${ }^{170}$

\section{Russian Far East - Sakhalin Island}

Sakhalin Island's importance as a crude-oil producing region is enhanced by its geographic proximity to the rapidly growing economies of the Far East. Three production sharing agreements have been negotiated so far. One agreement is waiting for the Oil and Gas Law to become approved before finalizing contracts. The Sakhalin II production- sharing agreement was signed with a clause inserted allowing it to abandon the area if legislation was not in place by a given date. ${ }^{171}$ Little infrastructure is currently available on Sakhalin for the transportation of crude oil-meaning substantial investment in infrastructure will be needed in order to reach full export potential.

FRS companies are involved in the following Sakhalin Island agreements:

- Sakhalin I with the Exxon-Sodeco consortium to develop the large Odoptu, Chaivo, and ArkutunDagi fields on Sakhalin Island, with potential reserves of 2 billion barrels of oil and almost 15 trillion cubic feet of gas. ${ }^{172}$

- Sakhalin II with the MMMMS Consortium (Marathon-USX, McDermott, Mitsui, Mitsubishi, and Shell). The $\$ 10$ billion deal includes the development of the large offshore fields, Lunsk (gas) and Piltun-Astokh (oil and gas). Potential reserves are estimated at 750 million barrels.

- Sakhalin III was divided into two different groups-offshore Blocks 1 and 2, covering over 2 million acres, went to Exxon, and Block 4 was awarded to a group composed of Texaco and Mobil. Block 3 was not awarded. ${ }^{173}$ Mobil has stated full exploration activity will commence upon conclusion of negotiations and enactment of pending Russian legislation on the Sakhalin III joint venture project with Texaco. ${ }^{174}$

\section{Western Siberia}

Amoco has a 50-percent interest in the Priobskoye field in the environmentally sensitive $\mathrm{Ob}$ river flood plain in which it has been providing environmental help. It is a unique project because it is the only oil and gas megaproject currently under consideration by the government that envisages joint development on an equal footing by a large vertically integrated Russian oil firm and a major U.S. energy company. ${ }^{175}$ The company expects production of almost 500,000 barrels per day of oil, but it will not begin the project until the passage of appropriate legislation. ${ }^{176}$

Occidental Petroleum has signed two enhanced oil recovery projects, one in Western Siberia and the other in the Komi Republic. The Vanyoganneft joint venture, established in 1992 with Chernogorneft Enterprise, is to develop the Vanyogan and Ayogan oil fields with estimated recoverable reserves at 200 million barrels of oil. Until Conoco's Polar Lights joint venture began production in August 1994, Occidental was the first and only FRS company that reported production in Russia, beginning in 1993. The difficulties facing foreign companies is reflected in Occidental's struggle to maintain production levels. Export restrictions have been cited by the company as hindering production. In 1994, cessation of exports by the Russian government caused Occidental to reverse its 1993 production from 50,000 barrels per day to 40,000 barrels per day in 1994 and decrease investment and expatriate staff. Exports were eventually reestablished in November 1994. ${ }^{177}$ The second enhanced oil recovery project, between Occidental (75 percent interest) and Ukhtaneftegasgeologica (25 percent interest), is in the Komi Republic and includes the 1.5-million-acre Block 15 in the Russian Federation's Komi Republic.

\section{The Caspian Basin}

The Caspian Basin, with an estimated 59 billion barrels of undiscovered oil, is believed to hold the largest oil reserves outside the Persian Gulf and Russia itself. ${ }^{178}$ In the Caspian region, the largest producers of crude oil are Azerbaijan and Kazakhstan. The FRS companies,

${ }^{169}$ DuPont, 1994 Annual Report, p. 23.

170"Foreign Investors Sober Up," Petroleum Economist (April 1995), p. 3.

${ }^{171}$ Petroleum Economist (April 1995), p. 3.

172 "Lack of Production Sharing Laws Slows Joint Ventures in Russia," Oil \& Gas Journal 93 (October 30, 1995$),$ p. 15.

${ }^{173}$ Petroleum Economist, Special Report 1995, p. 18.

${ }^{174}$ Mobil, 1994 Fact Book, p. 33.

${ }^{175}$ Petroleum Economist, Special Report 1995, p. 64.

${ }^{176 “ L a c k}$ of Production Sharing Laws Slows Joint Ventures in Russia," Oil \& Gas Joumal 93 (October 30, 1995$)$, p. 15.

${ }^{17}$ Occidental, 1994 Annual Report, p. 7.

${ }^{178}$ Estimated Petroleum Resources in the Former Soviet Union, U.S. Geological Survey Open-File Report 93-316, 1993 and "Russia Insists on a Slice of the Action," Petroleum Economist (March 1995), p. 14. 
particularly Amoco, Chevron, Exxon, Mobil, Oryx, and Unocal are intensively involved in the region. Currently, the most important issue concerns the pipeline infrastructure. Talks have been underway and several routes have been proposed to reach export markets.

The pipeline issue is of vital importance. Chevron has curtailed investments in Tengiz in part due to pipeline restrictions. Recently, the Caspian Pipeline Consortium, owned equally by Russia, Kazakhstan, and Oman, reached an agreement on a crude oil pipeline through Russia which could allow construction to begin in January 1996.

\section{Kazakhstan}

Kazakhstan has two big fields targeted for foreign investment. The giant Tengiz field has attracted Chevron, while British Gas and Agip are in the Karachaganak field. The Kazakhstan government views foreign investment and privatization as vital to its political and economic reform program. Currently, foreign investment is limited to joint ventures and production-sharing agreements with one or more designated Kazakhstan parties. Several FRS companies have been attracted to Kazakhstan with its large reserve base and what was once thought of as a more stable political environment than in Russia.

Like Russia, joint venture production has been kept to a minimum, but unlike Russia, Kazakhstan already has approved a viable legal framework for foreign investment from which laws can be developed. ${ }^{179}$ The main problems that need to be addressed are settlement of export and domestic pipeline issues and implementation of key infrastructure projects. Because Kazakhstan is a landlocked country, export pipelines play a large role in the success of further oil development.

In 1993, Chevron began a long-term investment in Kazakhstan at one of the largest fields in the world. This 40-year project to develop the Tengiz and Korolev oil fields is expected to total $\$ 20$ billion and is considered one of Chevron's biggest undertakings ever. Development of the massive Tengiz field could increase Chevron's total crude oil production by one-third, but transport to world markets remains a problem. ${ }^{180}$ Production was curtailed in 1994 due to transport restrictions through Russia. Chevron announced it will reduce spending on the oilfield for 1995 to $\$ 50$ million, from $\$ 500$ million originally budgeted, due to the inability to book adequate space on the only available export pipeline. ${ }^{181}$ Chevron wants to build a pipeline, but has refused to continue to negotiate with the Caspian Pipeline Consortium due to what it says is an unequal burden to finance the venture compared to its share in the project. Chevron has been looking for alternatives, and has been negotiating with the Azerbaijan International Oil Consortium, to look into alternative routes. Meanwhile, Kazakhstan and Chevron have been trying to attract companies like Mobil which can help finance the project and overcome political hurdles. ${ }^{182}$

Mobil has joined a consortium of European companies and was the first U.S. company selected by the Kazakhstan government to participate in the exploration of the country's highly prospective and environmentally sensitive offshore area of the Caspian Sea. In December 1993, the company signed an agreement to explore the Kazakhstan portion of the Caspian Sea. In addition, Mobil signed a 50-50 joint venture with three Kazakhstan state companies to explore the Tulpar field. The company plans to invest $\$ 80$ million in a 5-year exploration phase and follow with a 25-year development program. The project could bring in $\$ 4$ to $\$ 10$ billion for the company. ${ }^{183}$

In 1994, Oryx Energy signed two agreements to explore Kazakhstan's eastern Caspian Sea area. One is a 50-50 joint venture with two Kazakhstan partners to develop the Arman Field located in the north Buzachi Peninsula, discovered in the 1980's but not yet developed. The other involves exploration of a large block east of the Caspian Sea.

\section{Azerbaijan}

Azerbaijan, the oldest known oil-producing region in the world ${ }^{184}$ is opening its large reserves to foreign investment through joint ventures between foreign companies and the state oil company of Azerbaijan (SOCAR). Political instability associated with repeated changes of government might have limited the reform process, but the once major oil-producing region of the FSU is attracting foreign interest. Other risks associated with investing in Azerbaijan include the dispute over territorial waters of the Caspian Sea, poor infrastructure, and disputes over transportation routes.

\footnotetext{
179"Kazakh State Oil Enterprises Move Toward Privatization," Oil \& Gas Joumal 93 (August 21, 1995), p. 48.

${ }^{180}$ Chevron Corporation, 1993 Annual Report, p. 10.

181"Getting This Oil Takes Drilling and Diplomacy," New York Times (February 15, 1995), p. D1.

เ82"Oil Industry Awaits Possible Mobil/Kazakhstan Deal," Reuters (October 18, 1995).

${ }^{183}$ "Mobil Eyes $\$ 10$ Bn Reward In Onshore Exploration," Nefte Compass (April 20, 1995), p. 7.

เ81"Oil History, Potential Converge In Azerbaijan," Oil \& Gas Journal 93 (May 22, 1995), p. 32.
} 
FRS Companies operating in Azerbaijan include Amoco, Exxon, and Unocal. The Azerbaijani International Oil Consortium, an international 11-company group which includes the FRS companies Amoco (17 percent), Exxon (5 percent), and Unocal ( 9.5 percent), entered into a 30 year "contract of the century"185 in 1994. This contract is worth $\$ 7.5$ billion to $\$ 8$ billion to develop three offshore Caspian Sea oil fields. The combined fields hold an estimated 3 to 5 billion barrels of recoverable oil and gas reserves. Initial oil production is planned for late 1995 and peak production is estimated at 700,000 barrels of oil per day by 2010 , but is dependent on the development of pipeline transportation for Caspian oil to international markets.

\section{Latin American Petroleum Privatization}

As in the FSU, privatization in Latin American countries has occurred' in an atmosphere of rapid economic transformation. In the early 1990's, most Latin American countries embarked on a series of market-based economic reforms. These reforms have in some cases been universal, covering virtually the entire range of economic activities-fiscal, monetary, commercial, trade, and industrial policy. Central to Latin American economic reforms has been the privatization of a range of formerly state-owned industries, from phone companies to electric utilities to petroleum companies. Legal reform also has been key' to privatization; particularly with regard to treating foreign companies and domestic companies equally.

Although amounting to only 6 percent of total FRS foreign exploration and development spending in 1994, FRS compàny Latin American exploration and development spending has grown twice as fast as FRS exploration and development expenditures in other foreign locales (Table B34) and nearly doubled between 1987 and 1994 (Figure 26). Current FRS activity in Latin America is far flung, involving several countries and 'several types of activities. The following section highlights some of the more important recent FRS company developments in several Latin American nations.

\section{Argentina}

The privatization of Yacimientos Petroliferos Fiscales (YPF) represents one of the most significant and, as yet,

\section{Figure 26. 'FRS Company Exploration and Development Expenditures in Other Western Hemisphere Nations, 1987-1994}

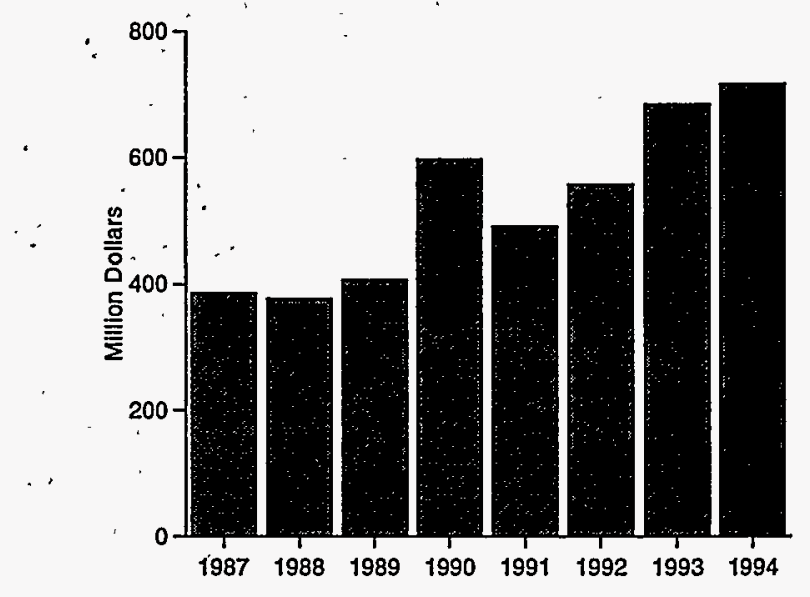

Source: Energy Information Administration, EIA Form 28.

successful of all Latin American' state-oil company privatizations. - In 1985, Argentina began a series of attempts to expose its domestic petroleum industry to foreign investment and market forces. The culmination of Argentina's petroleum industry liberalization was achieved with the privatization of the Argentine statepetroleum company YPF in 1993. In 1994, YPF ranked 35 among the world's oil producing companies and 41 among refiners, respectively, among the world's crude oil-producing companies and refining companies. ${ }^{186}$ The benefits realized from privatization have included new sources of investment and technology, which have been substantial and have been responsible for reversing years of declining oil production in Argentina. In 1990, Argentine crude oil production stood at 483,000 barrels per day, a level less than that produced a decade earlier. However, Argentine production reached 700,000 barrels per day, while 1 million barrels of crude are expected to be produced daily in the year $2000 .{ }^{187}$ In 1994, when drilling activity was generally down in other regions, Argentina experienced a 66-percent increase in its rig count between 1993 and $1994 .{ }^{188}$ An influx of private investment largely contributed to the turnaround in Argentine petroleum. For example, U.S. direct investment in Argentina's petroleum industry has climbed from $\$ 452$ million in 1989 to $\$ 773$ million in $1994 .{ }^{189}$

\footnotetext{
${ }^{185}$ Petroleüm Economist, Special Report, 1995, p. 62.

${ }^{186}$.PIW Ranks the World's Top 50 Oil Companies," Petroleum Intelligence Weekly 31 (December 12, 1994).

187"Privatization of State Company Catalyzes Argentine Oil Industry," Oil and Gas Journal 93 (February 13, 1995 ), p. 49.

${ }^{188}$ "International Rig Count," Oil and Gas Journal 93 (February 20, 1995), p. 104.

${ }^{189}$ U.S. Department of Commerce, Bureau of Eçonomic Analysis, Survey of Current: Business (Washington, DC), June issues $1990-1995$.
} 
FRS companies have been involved in Argentina's petroleum industry for several years. In 1994, Amoco's subsidiaries accounted for 7 percent of Argentina's crude oil production and Occidental's subsidiaries accounted for 3 percent. ${ }^{190}$ Exxon and Shell Oil Company's parent, Royal Dutch/ Shell, have owned major Argentine refineries for several years. Privatization may be responsible for some more recent FRS ventures. In 1993, YPF announced that it would modernize its flagship La Plata refinery with technical assistance from Chevron. In 1992, Enron led a joint venture that won the concession to own and operate one of the two Argentine national gas transmission systems divested by Argentina when the state gas company, Gas del Estado, was privatized. ${ }^{191}$ During 1994, Mobil was awarded exclusive blending and marketing rights for Mobil-branded lubricants with a major private Argentine marketer. ${ }^{192}$

In addition to encouraging foreign direct investment, privatization also may be responsible for a more outward-looking Argentine oil industry. YPF entered the ranks of major multinational oil companies with its acquisition of Maxus Petroleum in 1994. Maxus, a U.S. independent crude oil exploration and production company, has operations in Asia and the United States, in addition to Bolivia, Colombia, Ecuador, and Venezuela. Other recent actions by YPF also indicate an attempt to broaden its operations overseas:

- In 1994, YPF signed a contract with the Bolivian state oil company to explore for hydrocarbons near the Bolivian-Argentine border. YPF expects to invest $\$ 50$ million in the project. ${ }^{193}$ YPF also entered into a partnership in the early 1990's with Petrobras to develop gas reserves for possible export to Brazil. ${ }^{194}$ YPF recently engaged in exploration projects in Chile, Peru, and offshore Louisiana. ${ }^{195}$

- YPF also recently expanded marketing operations in Bolivia, Chile, and Peru. ${ }^{196}$.

\section{Mexico}

Despite some initial efforts, reform in Mexican petroleum has faltered. Foreign participation in oil and gas exploration, production, and refining remains proscribed by the constitutional requirement which allows only Pemex to engage in these activities. Pemex, the Mexican state petroleum company, is the world's third largest producer of crude oil and the ninth largest refiner in terms of crude oil refining capacity. So far, the only substantive reform measures completed include a restructuring of Pemex's operations, the placing of several chemical units and other non-core operations for sale, increased reliance on drilling contractors, and the pursuit of joint ventures abroad. Pemex's downstream operations have focused on reconfiguring and modernizing its refineries to both increase product output and address environmental concerns. Despite refinery upgrades, Pemex's refinery capacity is less than current product consumption, leading to increased product imports and further refinery construction. Pemex also has replaced some of its domestic shortfall through a 50-percent joint venture in Shell Oil's Deer Park, Texas, refinery. ${ }^{197}$

In contrast to Argentina, efforts at privatization of the Mexican petroleum industry and the opening of new business opportunities to FRS companies have been negligible. Mexico's recent privatization of large nonenergy public firms, ${ }^{198}$ along with the signing of the North American Free Trade Agreement (NAFTA), created some initial optimism among FRS companies that petroleum privatization would ensue. ${ }^{199}$ In 1991 , Chevron expanded its small representative office in Mexico City in the hope of signing a service deal to gain access to Mexican oil. Similarly, Amoco, Mobil, and Texaco were interested in Mexican investment. ${ }^{200}$

\section{Venezuela}

Although Venezuela's liberalization of its petroleum industry is more substantial than Mexico's efforts, it

\footnotetext{
190/Privatization of State Company Catalyzes Argentine Oil Industry," Oil and Gas Joumal 93 (February 13, 1995 ), p. 46.

${ }^{191}$ Oil and Gas Journal 93 (February 13, 1995), p. 52.

${ }^{192}$ Mobil Corporation, 1994 Mobil Fact Book, p. 56.

193"Bolivia Signs New Trade and Cooperation Accords with Chile and Argentina," Chronicle of Latin American Economic Affairs (October

194"Privatizations Open Exploration and Production Opportunities," World Oil 215 (August 1994), p. 41.

${ }^{195}$ YPF, 1994 Annual Report, p. 3.

${ }^{196}$ YTE, 1994 Annual Report, p. 2.

${ }^{197}$ George Grayson, "New President Pledges Economic Liberalization," Petroleum Economist (November 1994), p. 17.

${ }^{198}$ According to the magazine The Economist (August 21, 1993), these sales raised over $\$ 20$ billion.

${ }^{199}$ The Economist (August 21, 1993).

200"International Majors Flirt with Mexico Despite Restrictions," Petroleum Intelligence Weekly 30 (June 10, 1991 ), pp. 1-2.
} 20, 1994). 
still falls short of complete privatization, as has occurred in Argentina. Venezuela's efforts at privatization thus far have involved opening previously off-limit areas to foreign exploration and development. Still, Petroleos de Venzuela (PDVSA), the world's fifth largest producer of crude oil and the fourth largest refiner, has long been an internationally-oriented petroleum company. For instance, PDVSA's U.S. subsidiary, Citgo, is the largest marketer of gasoline in the United States. ${ }^{201}$ Along with its wholly-owned Citgo subsidiary, PDVSA has two joint-venture refining operations with ARCO's Lyondell subsidiary and with Unocal. In 1993, PDVSA was the third largest foreign-affiliated petroleum refiner in the United States. ${ }^{202}$ PDVSA also owns substantial refining operations in Europe and the Caribbean. ${ }^{203}$

During 1994, the Venezuelan congress approved two foreign joint-venture projects that involved FRS companies and subsidiaries of PDVSA (a third approved project does not involve any FRS companies). The \$5.6billion Cristobal Colon liquified natural gas export project will be undertaken by a consortium that includes Exxon and Lagoven, a PDVSA affiliate. This venture entails the first foreign ownership of Venezuelan hydrocarbon reserves since the 1975 oil law which created PDVSA was passed. The second project is a joint venture between DuPont and Maraven, another PDVSA affiliate, to produce heavy oil, which will then be upgraded and refined into products at DuPont's U.S. refineries. Lagoven and Maraven are two of PDVSA's three vertically-integrated petroleum subsidiaries.

A few other FRS companies are either currently discussing joint ventures or have formed joint ventures and are awaiting approval to proceed from the Venezuelan congress:

- ARCO and Corpoven, PDVSA's third vertically-integrated affiliate, are discussing a heavy oil production and upgrading project.

- Chevron agreed to do a feasibility study of a base lubricant manufacturing plant joint venture with Citgo and Maraven.

- DuPont is a member of a consortium awaiting congressional approval of a joint venture with the
PDVSA affiliate Bitor to produce and market the boiler fuel orimulsion.

- Enron is studying the feasibility of a joint venture with Maraven to produce petrochemicals.

- Mobil is studying the feasibility of two different heavy. crude upgrading joint ventures, one with Maraven and the other with Lagoven.

- Mobil bid on 10 oil fields, both onshore and offshore.

Some FRS companies also are undertaking ventures governed by service contracts with PDVSA and equity ventures that do not require congressional approval. Chevron and Maraven have created a heavy crude production joint venture with an operating contract, while Mobil is a member of a consortium to evaluate exploration and development opportunities in the new areas to be opened for exploration by Venezuela during 1995. Occidental signed a 20-year agreement with Maraven to increase oil production, and Occidental's Canadian subsidiary has formed a joint venture to bid on exploration and development contracts PDVSA is expected to offer during 1995. Venezuela's downstream petroleum sector also has been a recent target of FRS company investment. In 1995, Mobil bought a 50-percent interest in a company that operates the largest lubricants blending plant in Caracas.

\section{Brazil}

Petrobras, Brazil's state petroleum company, is the 21st largest company in the world in liquids production and the 10th largest refiner. Petrobras is owned chiefly by the Brazilian national and state governments and, to a lesser degree, by private enterprises and individuals through local stock market shares. Petrobras' operations are international in scope although not as extensive as those of PDVSA. During 1994, Brazil's national government began considering possible privatization plans in order to generate badly needed investment capital. In November 1995, the Brazilian Senate voted to end the state oil monopoly in petroleum exploration, importation, and refining. ${ }^{204}$ This act should do much to encourage foreign interest in Brazilian petroleum investments.

\footnotetext{
${ }^{201}$ National Petroleum News Market Facts '95 87 (mid-June 1995), p. 35.

${ }^{202}$ Energy Information Administration, Profiles of Foreign Direct Investment in U.S. Energy 1993, DOE/EIA-0466(93) (Washington, DC, May 1995), p. 20.

${ }^{203}$ Petroleos de Venezuela SA, Annual Report 1994, p. 33.

204"Brazil's Senate Votes to Open Oil Industry," New York Times (November 9, 1995), p. D8.
} 


\section{Colombia}

Ecopetrol, the Colombian state petroleum company, is the 36th largest producer of liquids and the 51st largest refiner in the world. Currently legal reforms to allow privatization of Ecopetrol are being considered. The most significant energy privatization effort thus far involves the Carrejon coal mine, which is jointly held by the state mining company and Exxon (each owns 50 percent of the mine). Buyers for the state share of the mine are still being sought. ${ }^{205}$

Recent privatization efforts created numerous opportunities for foreign investment in Colombia. British Petroleum discovered 2 billion barrels of reserves in the Cusiana and Cupiagua oilfields, which will be developed by a joint venture with Triton Energy, Total, and Ecopetrol. ${ }^{206}$ The joint venture also will spend $\$ 2$ billion upgrading Colombia's pipelines to transport the additional production. Another joint venture, which includes Ecopetrol, British Petroleum, Total, Triton Energy, and others, will build an oil export pipeline from the Cusiana Field. British Petroleum also purchased Maxus' 53-percent share of a block adjacent to the Cusiana Field, augmenting the 10-percent share it already held.

Recent FRS company activity in Colombia's petroleum industry includes the following:

- Amoco's Colombian subsidiary obtained a 60percent interest in a natural gas field.

- Chevron and Exxon have ongoing petroleum exploration and development operations.

- Enron and Ecopetrol have a joint venture to develop a 200-megawatt oil-fired electricity generating plant. Enron also leads a consortium that will build, own, and operate a 200-megawatt cogeneration plant in Cali.

- Exxon has a 50-percent share in the soon-to-beprivatized Carrejon mine.

- Texaco plans to expand its natural gas operations in Colombia through the addition of a second offshore platform during 1996 and engage in new exploration in the Middle Magdalena Valley. However, Texaco is leaving Colombian heavy oil production by selling five heavy oilfields during 1994 and plans to sell its remaining fields during 1995.

\section{Ecuador}

Ecuador is following the more typical privatization pattern of Latin American countries by privatizing most state nonenergy firms and selected energy assets. Petroecuador is the world's 48th largest producer of liquids and the 58th largest refiner. Sale of the state electric utility during 1995 is planned along with other strategic assets. ${ }^{207}$ Recent FRS company activity in Ecuador includes:

- Amoco and Mobil have a joint venture to operate a 25-year concession for a production block in the Amazon Basin.

- Oryx and Ecopetrol have an oilfield joint venture which is currently producing 8,000 barrels per day. Oryx also leads a consortium that won a 25-year production-sharing concession for an oilfield block in the Amazon.

- Mobil is entering petroleum marketing in Ecuador.

\section{Peru}

New oil legislation was passed in August 1993, leading to a return of foreign investment and to the eventual privatization of Petroperu. Peru already has released preliminary information for selling core assets of Petroperu. A new state agency, Perupetro, was established to promote, negotiate, and administer exploration and development contracts, for which Petroperu must compete with private firms.

Several FRS company investments have been made in Peru despite the recent delay in Petroperu's privatization. ${ }^{208}$ Chevron received approval to begin exploration and development in part of the large Camisea natural gas field in Peru's southeastern jungle, while Coastal Peru Ltd. signed an exploration and development contract with Petroperu for a tract in central Peru. Occidental won a 20-year development contract for a production tract in a commercially viable field. In August 1994, Mobil's Peruvian subsidiary was authorized to begin exploration. Mobil also is a partner in a 30 -year exploration and development joint venture in

205"Colombia," Privatization International (August 1,1995) and "Ecopetrol to Handle Privatization," International Coal Report (July 10, 1995).

${ }^{206}$ "Foreign and Private Investment Needed," World Oil 216 (August 1995), p. 45, and U.S. Department of Energy, Office of Oil and Natural Gas Policy, U.S. Energy Ventures in Latin America (July 1995), p. 26.

207"Getting in Step; Latin America Governments Turn to Private Sector for Infrastructure Needs," Latin Finance (June 1994), p. 22.

20s"Foreign and Private Investment Needed," World Oil 216 (August 1995), p. 45. 
Peru. Mobil and Royal Dutch/Shell have agreed to develop another part of the giant Camisea natural gas field through a joint venture. Mobil and Shell Oil are negotiating a contract with Perupetro for exploration and development rights to two blocks that surround the major Camisea fields. ${ }^{209}$ Downstream, Mobil bought several gasoline stations from Petroperu. Also, Petroperu is seeking buyers for 60 percent of the equity in each of two refineries with a total capacity of 164,000 barrels per day.

\section{China's Energy Privatization Efforts}

In recent years, China has also attempted to partially open its doors to foreign investment in domestic energy ventures. In many ways, China offers an alternative to the FSU and Latin America as a future source of petroleum reserves. China's state oil companies currently produce nearly 3 million barrels of crude oil per day, making China the world's sixth largest producer (See the box entitled "The Chinese Petroleum Industry" on this page). China is the world's largest producer of coal, which accounts for nearly three-quarters of all energy consumed in China. By contrast, coal accounts for less than a quarter of energy consumption in the United States.

In sharp contrast to the FSU, part of China's enormous potential stems from the strength of the Chinese economy, which has realized double-digit growth rates in recent years. Although both China and the FSU have been emerging from state-planned economies, China's current positive economic predicament is substantially different from that of the FSU. China's energy "problem" lies in the inability of its domestic energy industries to produce enough crude oil, petroleum products, coal, and electricity to keep pace with the rapid growth in domestic demand. Despite China's vast energy resources, China finds its current economic upswing jeopardized by energy shortages. Price controls and underinvestment have also hampered China's crude oil productive capacity. By the year 2000, crude oil consumption in China is expected to exceed domestic production by over a half million barrels per day. However, petroleum production is not the only energy industry facing difficulties in China. The rapidly growing Chinese industries continue to be hampered by periodic refined product and electricity shortages.

As with the FSU, China's attraction to foreign petroleum companies is enormous. However, China's potential for foreign investment has been hamstrung thus far by many of the same shortcomings found in the FSU. The erratic pace of China's petroleum industry privatization efforts is in part due to such difficulties as uncertainty over government policies, uncertainty over obtaining foreign exchange and materials, bureaucratic inertia, the absence of clearly defined property rights, and other legal issues. Recent FRS company investments have been directed at all aspects of China's energy industry-from oil and gas production, to petroleum transportation and refining. Electricity generation and coal mining have also been targets of FRS company investment (Table 28).

\section{Chinese Energy and FRS Companies}

In the past, upstream investments of western energy companies were restricted to offshore regions developed jointly with the China National Offshore Oil Corporation (CNOOC), as China's government wished to obtain sorely needed foreign technology without having to surrender control over resource bases. Earlier efforts to invite foreign participation were also hindered by confiscatory royalties and tax rates. Since 1982, there

\section{The Chinese Petroleum Industry}

In contrast to the FSU, the Chinese petroleum industry is still by-and-large a state enterprise with little likelihood of full privatization occurring any time soon. In China, there are currently four state petroleum companies. Two of these companies are primarily upstream concerns. While the China National Petroleum Corporation (CNPC) is responsible for all onshore exploration and production along with some small-scale refining, the China National Offshore Oil Corporation (CNOOC) is responsible for all offshore exploration and production. CNPC is responsible for 97 percent of China's crude oil production while CNOOC is responsible for 3 percent. China has two large state-owned downstream operations. The China National Petroleum Company (Sinopec) operates all large refineries, while the China Chemical Import and Export Corporation (Sinochem) is responsible for crude oil and petroleum products import/export activities.

\footnotetext{
209“'Peru's Petroleum Privatization to Gather Momentum in 1995," Oil and Gas Journal 93 (January 16, 1995), p. 14.
} 
Table 28. FRS Company Energy Investments in China

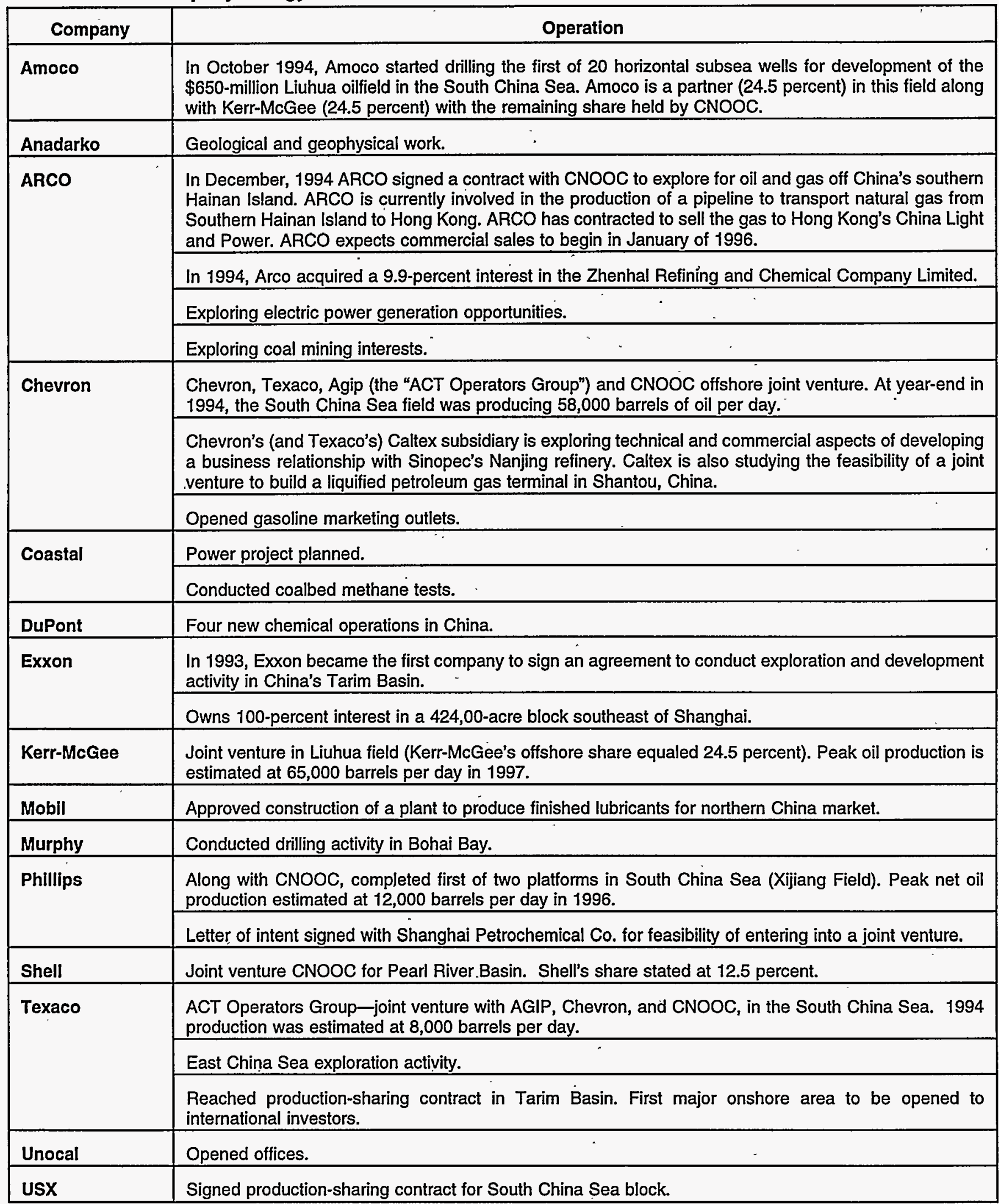

Sources: U.S. Department of Energy, U.S. Energy Ventures in China (Washington, DC, October 1995) and company annual reports. 
have been four rounds of bidding on offshore contracts-two-thirds of which were eventually awarded to U.S. companies. ${ }^{210}$ By 1993, U.S. companies had spent $\$ 1.2$ billion in offshore exploration and $\$ 300$ million on offshore development.

In early 1993, China opened the potentially promisingand largely unexplored-Tarim Basin to foreign companies. The Tarim Basin is located in a desolate and underdeveloped region in western China and is expected to have substantial crude oil reserves. Although encouraging joint ventures, the central government still wields a great deal of control over allocating investment, supply, and price in the domestic petroleum industry. For instance, in March 1994, the Chinese government placed severe restrictions on the importation of crude oil and refined products.

For the FRS companies, most investments have been limited to joint ventures with Chinese firms, although in 1994 ARCO acquired a 9.9-percent interest in China's Zhenahl Refining and Chemical Company Limited. This opening is in part due to the previously discussed inability of China to generate the enormous capital needed to expand an energy sector which has failed to keep pace with the rapid pace of Chinese economic growth in recent years. China is also sorely in need of foreign energy technology and equipment as much of China's energy industry is much less developed relative to world standards.

${ }^{210} \mathrm{R}$. Tansy, "Black Gold Rush," The China Business Reviéi 21 (July 1994), p. 12. 


\section{Appendix A \\ Structure of the Financial Reporting System - Form EIA-28}

\section{Reporting Format}

The FRS data system is designed to permit review of the functional performance of major energy-producing companies in total, as well as by specific functions and geographic areas of operation. The financial reporting schedules obtain data on revenues, costs, and profits, thereby indicating financial flows and performance characteristics. In addition, Form EIA-28 is used to collect balance sheet data (e.g., accumulated property, plant, and equipment), along with data on new investment in these accounts. To complement the financial data, statistical schedules are included to trace physical activity patterns and to evaluate several physical/financial relationships.

In greater detail, the structure of the reporting package is as follows:

\section{Financial Reporting}

a. The starting point is the three basic financial statements required by the Securities and Exchange Commission (SEC) Form 10-K:

i. Consolidating Statement of Income (Schedule 5110)

ii. Selected Consolidating Financial Data (Balance Sheets) (Schedule 5120)

iii. Consolidated Statement of Cash Flows (Schedule 5131)

b. Corporate-wide financial information is first disaggregated by functional lines (segments) on Schedules 5110 and 5120 as follows:
i. Petroleum
ii. Coal
iii. Other Energy (includes Nuclear)
iv. Nonenergy (includes Chemicals)

c. Nonenergy data are collected to describe corporate resource investment strategies and to allow aggregation of the FRS detailed schedules into the consolidated company amounts.

2. Operating and Statistical Information

a. For each type of energy activity, complementary operating information is obtained through the following schedules:

i. Petroleum (Schedule 5211-Schedule 5246)

ii. Coal (Schedule 5341)

b. The schedules are designed to correspond to the financial information so that level of effort in the financial sense can be compared to physical results.

3. Complementary Schedules

a. Examine corporate research and development funding priorities (Schedule 5111)

b. Reveal impact of tax policy on financial results of reporting companies (Schedule 5112)

c. Monitor raw material acquisition and refined product disposition strategies of FRS companies (Schedule 5211 and Schedule 5212)

d. Trace changes in reserves for petroleum (including natural gas) (Schedule 5246) and coal (Schedule 5341).

\section{Petroleum Segment Overview}

The petroleum line of business is further disaggregated into segments. ${ }^{211}$ These segments are presented as though each were a separate entity, with certain

${ }^{211}$ The other lines of business (Coal, Other Energy, and Nonenergy) were also disaggregated into segments, but only through 1986. 
limitations, entering into transactions with other segments and third parties.

The following lists each segment within the petroleum line of business along with a brief description of that segment's principal revenue-generating product or service. (Further detail on the FRS petroleum segments may be found in the section on FRS Petroleum Supply and Trading Function and FRS Income Taxes.)

1. U.S. Production - produces and sells U.S. crude oil, natural gas, and natural gas liquids. For FRS purposes, sales of U.S. crude oil can be made to the U.S. refining/marketing segment. Natural gas and natural gas liquids can be purchased from or sold directly to U.S./foreign third parties, unconsolidated affiliates, and other U.S./foreign segments.

2. U.S. Refining/Marketing - purchases raw materials from the U.S. production segment, the foreign refining/marketing segment, and third parties for refining or sale to third parties. The segment also purchases directly from the foreign production segment for those companies that do not have foreign refining/marketing and import all foreign production and purchases.

3. U.S. Pipelines - transports crude oil, natural gas, and natural gas liquids through Federal or State regulated pipeline operations.

4. Foreign Production - produces and sells foreign crude oil, natural gas, and natural gas liquids. Oil sales are made to the foreign refining/marketing segment unless the company does not have foreign refinery operations and imports all foreign oil production and purchases, Companies that meet these criteria may sell directly to the U.S. refining/marketing segment.

5. Foreign Refining/Marketing - purchases raw materials from foreign production segments and U.S. refining/marketing segments, refines, and sells to third parties and refining/marketing segments.

6. International Marine - provides marine transportation of foreign and U.S. source crude oil.

\section{Selection of FRS Reporting Companies}

Twenty-seven companies were initially notified of a requirement to file Form EIA-28. This group was initially chosen from the top 50 publicly owned U.S. crude oil producers who, in 1976, had at least 1 percent of either the production or the reserves of oil, gas, coal; or uranium in the United States or 1 percent of refining capacity or petroleum product sales in the United States.

Mergers, acquisitions and spinoffs, together with the selection criteria applied to 1991 data, resulted in the list of companies shown in Table A1 on the following page.

\section{Data Quality Assurance Program}

The data quality assurance program encompasses ELA's efforts to ensure the quality and integrity of FRS data. These efforts are evidenced by the design of the form and by the procedures applied to verify the data, i.e., the machine programmed checks and desk audit.

\section{Forms Design}

The Securities and Exchange Commission (SEC) Form 10-K contains financial statements audited by independent certified public accountants. These financial statements and the entire text of the annual report and Form $10-K$ are reviewed by the SEC staff in order to provide the investing public with assurances that data filed on Form 10-K are accurate and are in accordance with generally accepted accounting principles and SEC Regulations.

In order to take advantage of the SEC review and the audit by certified public accountants, the FRS Form EIA-28 is designed in a multitier structure. This structure presents both the Form 10-K figures and statistics and the more detailed data required by the FRS system. The top FRS tier corresponds to Form 10-K; the second tier is the first tier disaggregated into the different sources of energy (e.g., petroleum, coal); and the third tier is the second tier disaggregated into the specific functional line-of-business segments within petroleum. (See the Petroleum Segment Overview section at the beginning of this appendix, which describes the FRS segments in detail.) The fourth tier provides further detail within the individual segments, for example, the details of petroleum raw materials purchased and sold. Therefore, the lower tiers can be aggregated to each successively higher tier until the consolidated Form 10-K figures are reached. In this way, the more detailed FRS data is tied to the aggregated figures already reported publicly to the SEC and to individual company shareholders. 
Table A1. Companies Reporting to the Financial Reporting System, 1977-1994

\begin{tabular}{|c|c|c|c|c|c|c|c|c|c|c|}
\hline Company & $1977-81$ & 1982 & $1983-84$ & $1985-86$ & 1987 & 1988 & 1989-90 & 1991 & $1992-93$ & 1994 \\
\hline Amerada Hess Corporation & $\mathrm{X}$ & $x$ & $x$ & $\mathrm{x}$ & $\mathrm{x}$ & $x$ & $\mathrm{x}$ & $x$ & $x$ & $x$ \\
\hline American Petrofina Inc. & $x$ & $x$ & $x$ & $x$ & $x$ & $x$ & $x$ & & & \\
\hline Amoco Corporation ${ }^{b}$ & $x$ & $x$ & $x$ & $x$ & $\mathrm{x}$ & $x$ & $x$ & $x$ & $x$ & $\mathrm{x}$ \\
\hline Anadarko Petroleum, Inc. & & & & & & & & & $x$ & $x$ \\
\hline Ashland Oil, Inc. & $\mathrm{X}$ & $x$ & $x$ & $x$ & $\mathrm{x}$ & $x$ & $\mathrm{x}$ & $x$ & $x$ & $\ddot{x}$ \\
\hline Attantic Richfield Co. (ARCO) & $x$ & $x$ & $x$ & $x$ & $x$ & $x$ & $\mathrm{x}$ & $x$ & $x$ & $x$ \\
\hline BP America, Inc." & & & & & $x$ & $x$ & $x$ & $x$ & $x$ & $\hat{x}$ \\
\hline Burlington Northern Inc. & $x$ & $\mathrm{x}$ & $\mathrm{x}$ & $x$ & $\ddot{x}$ & & & & & \\
\hline Burtington Resources Inc. & & & & & & $x$ & $\mathrm{x}$ & $x$ & $x$ & $x$ \\
\hline Chevron Corporation ${ }^{1}$ & $x$ & $x$ & $x$ & $x$ & $x$ & $x$ & $x$ & $\mathrm{x}$ & $x$ & $\mathrm{x}$ \\
\hline Citles Service ${ }^{9}$ & $x$ & $\mathrm{x}$ & & & & & & & & \\
\hline Coastal Corporation & $x$ & $x$ & $x$ & $x$ & $\mathrm{x}$ & $\mathrm{x}$ & $\mathrm{x}$ & $x$ & $x$ & $x$ \\
\hline Conoco $^{h}$ & $x$ & & & & & & & & & \\
\hline E.J. du Pont de Nemours and Co. ${ }^{h}$ & & $x$ & $x$ & $x$ & $x$ & $x$ & $\mathrm{x}$ & $x$ & $x$ & $x$ \\
\hline Enron Corporation & & & & & & & & & $\mathrm{x}$ & $\mathrm{x}$ \\
\hline Exxon Corporation & $\mathrm{x}$ & $\mathrm{x}$ & $x$ & $x$ & $x$ & $x$ & $\mathbf{x}$ & $x$ & $x$ & $x$ \\
\hline Fina, Inc. & & & & & & & & $\mathrm{x}$ & $\ddot{x}$ & $x$ \\
\hline Getty Oil & $x$ & $\mathrm{x}$ & $x$ & & & & & & & \\
\hline Gulf Oil & $x$ & $\mathrm{x}$ & $\mathrm{x}$ & & & & & & & \\
\hline Kerr-McGee Corporation & $x$ & $x$ & $x$ & $x$ & $x$ & $x$ & $x$ & $x$ & $x$ & $x$ \\
\hline Marathon & $x$ & & & & & & & & & \\
\hline Mobil Corporationk & $\mathrm{x}$ & $x$ & $\mathrm{x}$ & $x$ & $x$ & $x$ & $x$ & $x$ & $x$ & $x$ \\
\hline Nerco, Inc.! & & & & & & & & & $\mathrm{x}$ & \\
\hline Occidental Petroleum Corporation 9 & $\mathbf{x}$ & $\mathbf{x}$ & $x$ & $x$ & $x$ & $\mathrm{X}$ & $x$ & $\mathrm{x}$ & $\mathrm{x}$ & $\mathrm{x}$ \\
\hline Oryx Energy Company ${ }^{m}$ & & & & & & $x$ & $\mathrm{x}$ & $x$ & $x$ & $x$ \\
\hline Phillips Petroleum Company & $x$ & $x$ & $x$ & $x$ & $x$ & $x$ & $x$ & $x$ & $x$ & $x$ \\
\hline Shell Oil Company & $x$ & $x$ & $x$ & $x$ & $x$ & $\mathrm{x}$ & $x$ & $\mathrm{x}$ & $x$ & $x$ \\
\hline Standard Oil Co. (Ohio) (SOHIO) ${ }^{c}$ & $x$ & $\mathrm{x}$ & $x$ & $x$ & & & & & & \\
\hline Sun Company, Inc." & $x$ & $x$ & $x$ & $\mathrm{x}$ & $x$ & $x$ & $\mathrm{x}$ & $x$ & $x$ & $x$ \\
\hline Superior Oilk & $\mathrm{x}$ & $x$ & $x$ & & & & & & & \\
\hline Tenneco Inc. ${ }^{n}$ & $x$ & $x$ & $\mathrm{x}$ & $\mathbf{x}$ & $x$ & $x$ & & & & \\
\hline Texaco Inc.! & $x$ & $x$ & $x$ & $x$ & $x$ & $\mathrm{x}$ & $x$ & $x$ & $\mathrm{x}$ & $x$ \\
\hline Total Petroleum (North America) Ltd. ${ }^{\circ}$ & & & & & & & $x$ & $x$ & & \\
\hline Union Paciflc Corporation & $\mathrm{x}$ & $\mathrm{x}$ & $\mathrm{X}$ & $x$ & $\mathrm{x}$ & $\mathrm{X}$ & $x$ & $\mathrm{x}$ & $\mathrm{X}$ & $x$ \\
\hline Unocal Corporation & $x$ & $x$ & $\mathrm{X}$ & $x$ & $\mathrm{x}$ & $\mathrm{X}$ & $\mathrm{x}$ & $x$ & $\mathrm{X}$ & $x$ \\
\hline USX Corporation & & $\ddot{x}$ & $x$ & $x$ & $x$ & $\ddot{x}$ & $x$ & $\ddot{x}$ & $x$ & $x$ \\
\hline
\end{tabular}

American Petrofina, Inc. changed its name to Fina, Inc., effective April 17, 1991.

${ }^{\mathrm{b}}$ Formerly Standard Oil Company (Indiana).

'In 1987, British Petroleum acquired all shares in Standard Oil Company (Ohio) that it did not already control and renamed its U.S. affiliate, BP America.

${ }^{\delta}$ Burlington Resources was added to the FRS system and Burlington Northern was dropped for 1988. Data for Burlington Resources covers the full year 1988 even though that company was not created until May of that year.

EFormerly Standard Oll Company of California.

'Chevron acquired Gulf Oil in 1984 but separate data for Gulf continued to be available for the full 1984 year.

IOccidental acquired Cities Service in 1982. Separate financial reports were available for 1982, so each company continued to be treated separately until 1983.

"DuPont acquired Conoco in 1981. Separate data for Conoco were available for 1981, DuPont was included in the FRS system in 1982.

Texaco acquired Getty in 1984; however, Getty was treated as a separate FRS company for that year.

JU.S. Steel (now USX) acquired Marathon in 1982.

${ }^{k}$ Mobil acquired Superior in 1984 but both companies were treated separately for that year.

'ATZ America acquired the common stock of Nerco, Inc. on Feb. 17, 1994. In Sept. 1993, Nerco, Inc., sold Nerco Oil \& Gas, Inc., its subsidiary. Nerco's 1993 submission includes operations of Nerco Oil \& Gas, Inc., through Sept. 28, 1993.

mSun Company spun off Sun Exploration and Development Company (later renamed Oryx Energy Company) during 1988. Both companies were included in the FRS system for 1988; therefore some degree of duplication exists for that year.

"Tenneco sold its worldwide oil and gas assets and its refining and marketing assets in 1988. Other FRS companies purchased approximately 70 percent of Tenneco's assets.

${ }^{\circ}$ Effective June 1, 1991, Total's exploration, production and marketing operations in Canada were spun off to Total Oil \& Gas, a new public entity. " $X$ " indicates that the company was included in the FRS system for the year indicated.

Source: Energy Information Administration, Form EIA-28. 


\section{Review Procedures}

Detailed machine editing and desk review procedures have been established for the incoming FRS data. The result of each review is the issuance of a letter to the reporting company containing questions regarding data elements. The reporting companies respond to each question, either by explaining the item or by amending any incorrect schedule. Amended schedules are reprocessed like the original with the full range of desk and machine checks. The result of this process is an internally consistent database which has been reconciled to the SEC Form 10-K, and from which the output reports can be compiled.

The FRS review procedures include:

- Machine programmed checks for mathematical accuracy (e.g., addition and subtraction)

- Machine programmed checks to insure that corresponding schedules are correctly crossreferenced

- Desk reviews comparing reported FRS data to information from each company's Form $10-\mathrm{K}$ and annual report

- Desk reviews comparing reported data (e.g., average cost per foot drilled) for an individual FRS company to the average for all FRS reporting companies and to prior year information

- Desk reviews comparing reported data to other related data series to ascertain any unusual variance

- Statistical disclosure avoidançe procedures.

\section{Machine Programmed Checks}

There are 803 machine programmed checks for mathematical accuracy which ensure that each horizontal and vertical total equals the sum of the amounts within each line or column. There are also 50 machine programmed cross reference checks which ascertain that the amounts within a certain section of a schedule equal the amounts of the same description within a different schedule. The cross-reference checks are performed to ensure accuracy and consistency between different schedules. For example, the amount reported on Schedule 5210 for the U.S. production segment charges for depreciation, depletion and amortization is cross-referenced to ensure the same amount is reported on Schedule 5120. Since the number and type of errors noted during these checks is an indicator of respondent understanding of the form, existing and potential problems are identified. The FRS review staff can then focus most of their attention on specific companies and areas where data accuracy may be more of a problem:

\section{Desk Review Procedures}

This is the detailed comparison of the data submitted to the FRS system to information contained in the Form $10-\mathrm{K}$ report and the annual report to shareholders as well as other publicly available information.

As stated previously, the Form $10-\mathrm{K}$ report and the annual report contain financial information that has been audited by independent certified public accountants. This financial information along with textual and statistical information has also been reviewed by the SEC staff, which includes not only accountants, lawyers, and financial analysts, but also petroleum and mineral resource engineers. Hence, the data contained in these documents is considered a valuable reference in connection with the quality of FRS data.

The data contained in each respondent's submission is compared to the Form $10-\mathrm{K}$ and the annual report material using a detailed review program. Each review program step is performed by trained auditors supervised by CPA's with experience in auditing medium to large public companies.

These comparisons involve checking elements in both the financial and physical information areas (e.g., production, reserves, refinery statistics, etc.). Direct comparisons are made of specific data elements from the FRS form with corresponding items on Form 10-K or in the annual report. Indirect comparisons deal with information that is mentioned in Form $10-\mathrm{K}$ and the annual report but which is not quantified sufficiently for direct matching with FRS data. For example, if a respondent's annual report discussed an investment in coal, appropriate entries would be expected on the FRS schedule for coal.

The FRS desk review procedures also include two other types of comparisons. The first type of comparison is made against prior year FRS data of the reporting company as well as current average data for all FRS reporting companies. These procedures assure consistency and reasonableness across reporting years.

The second type of desk review involves comparison to other related data series. Information contained in the FRS system is compared to data available from other DOE systems and published data, such as State mining surveys. 
The FRS desk review procedures described above often lead to the formulation of a set of questions which are issued to the reporting companies each year. Response to these questions generates substantial interchange between the energy company staffs and the FRS staff. From this interchange the company personnel acquire a better understanding of the unique aspects of the FRS system. The FRS staff learns more about each reporting company, the industry, and how each company's accounting and reporting practices might affect the published FRS aggregate data.

\section{Statistical Disclosure Avoidance Procedures}

Procedures to prevent the disclosure of "individually identifiable energy information" have been applied to each table in this report. These tables provide summary rather than company-specific information. In most cases, the level of summarization is for all FRS companies. In certain cases, subcategories have been established that break the reports into size or other descriptive classes. Each table has been screened to ensure that no statistical disclosure will occur.

A large number of summary computer reports, generated from a single selected database, provide the basis for these tables. In conjunction with the summary reports, a parallel set of cell count reports were produced that tabulate for each report cell the number of nonzero values that were aggregated to produce the summary value. The cell count reports were then reviewed to identify whether potential disclosure problems would result from having an insufficient number of reporters or from having values that represent primarily dominant companies in a particular energy sector or activity.

If potential disclosure problems are identified, the tables are restructured to combine values or groups of individual cells in the tables so that the resulting tables are essentially disclosure free.

\section{Financial Analysis Guide}

\section{Indicators of Financial Performance}

To depict the activities of the FRS companies classified by the various energy industries, several indicators have been selected to show the amounts and geographic distribution of production, profits, cash generated, accumulated investment, and annual new investment. These indicators are compared across segments, across functions within segments, and geographically. They are the same, or similar, to indicators which have been in regular use by financial analysts and economists for many years. However, to avoid potential misunderstandings, the measures used, their significance, and their limitations are described below.

All of these measures are based upon the existing framework of financial reporting now used by industry, which relies on Generally Accepted Accounting Principles (GAAP). GAAP is the set of accounting principles by which industry reflects the financial results of operations, cash flows, and financial position of individual business enterprises. The two primary problems one must contend with in using present GAAP-based data is that not all companies use the same GAAP accounting methods (e.g., full cost versus successful efforts in petroleum) and GAAP is based upon historical cost accounting principles (inflationary distortions and market values are not reflected). Both of these can cause a degree of noncomparability of reported data, across companies in the case of accounting methods, and through time in the case of historical cost accounting. In spite of these problems, the data are still regarded as meaningful, especially for trend analysis. (For a further discussion of these two problems, see the Accounting Practices section of this appendix.)

The financial measure of the production and distribution of raw materials and refined products is operating revenues, or sales. Under GAAP, this measure is based on arms-length transactions with third parties. However, in the FRS system the concept of sales has been extended to include sales from one segment to another. In such an approach, one segment's sales become another segment's costs, which must be eliminated in consolidation. The establishment of the FRS segments, the definition of sales (trading function), and the nontraceable and eliminations categories are discussed more fully in the Accounting Practices section of this appendix.

Profits are the measure of financial return for company activities. In the FRS system, profits are expressed in terms of net income, operating income, and contribution to net income. The first term applies only to the consolidated company profits, and represents income after the provision for income tax expense: Operating income applies both to the segments and to the consolidated company and is the net of operating revenues and operating expenses. Excluded from this figure are such items as income taxes and interest income and expense which are not allocated to the segments because they are "corporate level" items for FRS system purposes. (This is explained more fully in the Accounting Practices section of this appendix.) Contribution to net 
income is meant to be the equivalent of net income for individual segments and excludes several corporatelevel items which are not allocated to the segment level.

"Cash flow from operations" is presented for the consolidated company and generally follows the indirect or reconciliation method of reporting cash flow from operations allowed by Statement of Financial Accounting Standards No. 95. The indirect method adjusts net income to remove the effects of changes in receivables, payables, and inventory during the year. The indirect method also adjusts for the effects of depreciation, depletion, and amortization, gains or losses on disposition of property, plant, and equipment, and other items. "Cash flow from operations" represents the cash effects of producing and delivering the company's products and services. This presentation is useful in analyzing the ability to generate future positive cash flow, adequacy of cash flow in relation to current obligations, and the relationship of net income to cash flow.

Accumulated investment is expressed by (1) total assets, (2) net property, plant, and equipment (PP\&E), (3) investments and advances to unconsolidated affiliates, and (4) net investment in place.

Total assets are used in the context of the consolidated company figures, and are the total of the left-hand, or asset side, of the balance sheet.

Net PP\&E is frequently used as a measure of resources committed by an enterprise to an industry or segment. In the energy industry, net PP\&E accounts for the bulk of the consolidated assets.

Investments and advances to unconsolidated affiliates are of interest because many energy companies extend the range of their activities through subsidiaries of which they own less than 50 percent.

Finally, net investment in place is the total of: (1) net PP\&E and (2) investments and advances to unconsolidated affiliates.

Annual new investment is the measure of newly committed resources during any given year. In the FRS system, this is expressed in terms of: (1) additions to PP\&E; (2) current capitalized exploration and development (E\&D) expenditures; (3) current expenditures on E\&D; (4) additions to investment in unconsolidated affiliates; and (5) additions to net investment in place. The key words are: current, which means simply a current commitment of resources; and capitalized, which refers to expenditures which are classified as an addition to the PP\&E account in the balance sheet rather than as an expense of the current year in the income statement. Being capitalized indicates that the expenditure benefits future years and will be amortized to expense in the years benefitted. Being expensed means the benefit is to the current year and, therefore, the item should be shown as an expense of generating that year's revenues. The capitalization concept is at the heart of the difference between the successful efforts versus full cost accounting methods (discussed in the Accounting Practices section of this appendix.). Therefore, in the FRS system, total expenditures that are both expensed and capitalized are used as a measure of activity in order to standardize the measurement of resources invested.

\section{Foreign Reserve Interests}

This category includes all three types of foreign reserves collected on the FRS form: (1) net ownership interest reserves; (2) proportionate interest in investee reserves; and (3) foreign access reserves. These three foreign categories are added together for purposes of comparison "with U.S. net working interest reserves because of the different nature of company interests in foreign production as compared to U.S. production.

Foreign petroleum reserve statistics are not strictly comparable to those of U.S. petroleum reserves because of the more complex and varying arrangements whereby U.S. companies obtain foreign crude oil. In addition, such arrangements have been known to be changed suddenly by those governments, thereby imposing a degree of uncertainty about what a reporting company can describe as their equity reserves. Foreign reserve statistics may be used as an indicator of the rate and magnitude of industry activity, but the fact that their character is distinct from those of U.S. reserves must be recognized.

\section{Accounting Practices}

\section{Relation of FRS to Generally Accepted Accounting Principles}

In completing the FRS form, with one exception noted below, companies use the same generally accepted accounting principles that they use in their financial statements filed with the SEC and in their annual reports to shareholders. Therefore, the amount and timing of income recognized and the capitalization policies will be the same, and net income in the FRS system will agree in total with that reported in each company's financial statements. 
However, in the FRS system the presentation of the details of financial and statistical data will usually differ somewhat from that presented by most individual companies because current reporting standards do not require standardized business segments with standardized financial statement line items. In the FRS system, such standardization is necessary because of the need to aggregate a large number of companies (see Sec. 205(h), P.L. 95-91).

\section{FRS Petroleum Supply and Trading Function}

In establishing the FRS functional lines of business for reporting the activities of vertically integrated enterprises, it was necessary to define a set of trading rules. The rules define the activities which each segment can engage in. Otherwise, the segment data would be inconsistent between companies.

FRS defines the following segments within petroleum; they are the main components of the 5200 series schedules:

- U.S. Production

- U.S. Refining/Marketing

- U.S. Pipelines

- Foreign Production

- Foreign Refining/Marketing

- International Marine (Transportation).

A few of the more noteworthy rules, intended to make the trading activities of each FRS reporting company comparable to those of the other companies, are as follows:

1. Transfers (sales) between segments of the same company are recorded at arm's-length market prices. Where there are no comparable arm's-length transactions, field posted prices may be used. If third party realizations for specific raw material streams are below posted prices, the same lower prices should be used to value internal transfers of those raw materials.

2. All crude oil produced is recorded as a sale by the respective foreign, or U.S. production segments to the corresponding foreign or U.S. refining/ marketing segments. The production segments are not permitted to sell crude oil directly to third parties but instead must transfer it to the company's refining/marketing segments which sell, in turn, to the third parties. Companies that do not have foreign refining and import all foreign purchases may deviate from this practice and sell directly to U.S. refining/marketing.

3. Crude oil purchased from third parties is reflected as a purchase by the appropriate refining/marketing segment: foreign refining/marketing for foreign source crude oil and U.S. refining/marketing for U.S. source crude oil. Foreign source crude oil destined for a U.S. refining segment is then recorded as a sale by the foreign refining/ marketing segment to the U.S. refining/marketing segment.

4. Although production segments are neither sellers nor purchasers of crude oil from third parties, by FRS system convention, natural gas may be both purchased and sold by production segments.

5. All transportation costs are incurred by the purchasing segment. Therefore, when U.S. refining/marketing segments purchase crude oil from foreign refining/marketing segments, the U.S. refining/marketing segment incurs the transportation cost.

6. With regard to sales to third parties, an export sale is a sale shipped free on board (f.o.b.) destination to a foreign location. In contrast, if a sale is made f.o.b. to a U.S. location, it is considered a U.S. sale even though the goods may ultimately be shipped overseas by a third party who purchased the goods.

7. A U.S. purchase is a purchase made from U.S. sources, even though, in the case of goods purchased from third parties, the materials purchased may be of foreign origin. In the FRS system the point of purchase and not the country of production is the determining factor.

\section{Nontraceables and Eliminations}

One of the objectives of the FRS system is to allow economic and financial analysis of the energy industry to be performed by individual functions. These functions, referred to in the FRS system as segments, are presented as separate entities with their own income statements. They reflect sales and purchases not only to and from unaffiliated parties but also to and from other segments. Because the segments are not separate entities, but are part of an integrated firm, two special classifications are defined which allow reconciliation of consolidated company figures with those of the segments. 
The first is the nontraceable classification, which covers those items included in the consolidated financial statements but not allocated to the segments. The second is the eliminations classification, which prevents double counting of intersegment transactions when the segments are consolidated into total company figures.

The nontraceable classification captures assets, liabilities, revenues, and expense items which cannot be attributed to the activities of a segment. In the FRS data, this classification reflects general overhead for the consolidated firm and financial activities which represent corporate level activities.

While the financial transactions may play a key role in the firm's ability to do business, such transactions are not allocated to activities in an individual segment. The cash, corporate investments, interest income, and interest expense are examples of this. The accompanying example illustrates a nontraceable item, interest expense of $\$ 20$, and the $\$ 10$ corresponding tax effect (see "FRS Segment Tax Allocation Rules" in this appendix for further explanation).

The need for the eliminations classification arises when the product of one segment is sold to a second segment, which, in turn, sells the product again. In the example illustrated in Table A2, $\$ 80$ of crude oil is sold by the U.S. production segment to the refining/marketing segment. The refining/marketing segment records $\$ 80$ of purchases of crude oil and, after processing, reflects sales of $\$ 160$ of refined product. If the segment figures were simply added to arrive at the consolidated total, the consolidated sales figure of $\$ 240(\$ 80+\$ 160)$ would be too high because of double counting. Thus, the eliminations classification subtracts $\$ 80$ of sales and $\$ 80$ of costs, leaving consolidated sales of $\$ 160$, the appropriate measure of the firm's consolidated transactions.

The nontraceables and eliminations classifications are treated as if they are segments for purposes of aggre: gating segment data to the consolidated level.

\section{FRS Income Taxes}

FRS Segment Tax Allocation Rules. In the FRS system, the tax allocated to each segment reflects a prorata share of consolidated income taxes. Where the consolidated company reports income and pays a tax, but an individual segment incurs a loss, the segment with a loss reflects a tax benefit. This treatment is an FRS rule whose purpose is to reflect, at the segment level, the effect of the segment's operations on the consolidated income taxes. The tax benefit reflected at the segment level is limited to the extent it offsets taxes in other segments on a consolidated basis.

In comparing an FRS company's segment to a specialized (nonintegrated) company in the same line of business, one must consider the effect of the above described rule. The current tax effect may be different, since a specialized company cannot report tax benefits for operating losses incurred in that year. It must carry the loss forward, or backward, against profits of other years, while a segment of an otherwise profitable consolidated firm can show a tax benefit by FRS conventions because a segment's loss can offset profits in other segments on a' consolidated basis.

Table A2. Example of Nontraceables and Eliminations

\begin{tabular}{|c|c|c|c|c|c|}
\hline Financial Items & Consolidated & Elimination & Nontraceable & $\begin{array}{l}\text { Refining/ } \\
\text { Marketing }\end{array}$ & Production \\
\hline Revenues ............ & 160 & $(80)$ & - & 160 & 80 \\
\hline \multicolumn{6}{|l|}{ Less Expenses: } \\
\hline $\begin{array}{l}\text { General and } \\
\text { Administrative ......... }\end{array}$ & 10 & - & 2 & 5 & 3 \\
\hline Other Operations $\ldots \ldots$ & 10 & - & - & 5 & 5 \\
\hline Crude $\ldots \ldots \ldots \ldots \ldots$ & - & (80) & - & 80 & - \\
\hline Operating Income ....... & 140 & - & (2) & 70 & 72 \\
\hline Less Interest Expense . . . . . & 20 & - & 20 & - & $\therefore$ \\
\hline Less Income Taxes . . . . . . & 60 & - & (11) & 35 & 36 \\
\hline Net Income $\ldots \ldots \ldots \ldots$ & 60 & - & (11) & 35 & 36 \\
\hline
\end{tabular}

Note: Numbers in parentheses are negative. 
FRS Reporting Companies, Segments, and Tax Paying Entities. FRS reporting companies and their segments differ from the entities which actually pay income taxes. The FRS system reports energy activities on a consolidated company basis, disaggregated into various energy lines of business. Accordingly, income tax expense, current and deferred, is reflected on a line-ofbusiness basis. However, under the tax laws, taxes are not necessarily based upon FRS reporting company consolidated earnings of the FRS line-of-business segments.

The tax-paying entities of an FRS reporting company are its subsidiaries. Some are incorporated in the United States and some in foreign countries, and each may operate in the United States, foreign countries, or both. Income tax expense in the FRS system consists of both U.S. and foreign income taxes incurred by these subsidiaries. Taxes reflected by the consolidated company and each individual segment are allocated from taxes paid and deferred by the actual tax-paying entities.

Under U.S. tax law, U.S. income taxes are not required to be paid by foreign corporations on their foreign operations. Only income of foreign corporations earned in the United States or paid into the United States as dividends to a U.S. parent corporation (owner) are taxed by the United States. Foreign and U.S. earnings of U.S. corporations, including divisions and branch operations, are taxed by the United States. All income subject to U.S. tax, whether the entity is a foreign or U.S. corporation, is given the benefit of the foreign income tax credit (up to the statutory rate) to avoid double taxation. Each U.S. incorporated subsidiary of a U.S. corporation elects either to be included in a consolidated U.S. tax return or to file a separate return, depending on which election is most likely to minimize the aggregate U.S. and foreign taxes. In the FRS system corporate organization and relationships are not purely a function of line-of-business financial reporting. This fact requires that allocations be made of taxes incurred so that they can be classified according to the FRS segment format. These allocations are required when a subsidiary is involved in both U.S. and foreign operations and/or in more than one line of energy business. For example, the FRS system has separate segments for the foreign and U.S. petroleum production business, and for the foreign and U.S. refining/marketing business. Therefore, if an FRS reporting company has a foreign subsidiary involved in both petroleum production and refining/marketing of petroleum, a disaggregation of that subsidiary's activities, including income taxes, must be performed.

The disaggregation is further complicated by the existence of nontraceable items, such as interest expense, interest income, minority interest and foreign currency gains and losses. The nontraceable column must be treated as a separate segment when making the tax allocation. Therefore, the nontraceable columns should generate U.S. and foreign income tax benefits.

\section{Deferred Taxes}

The Financial Accounting Standards Board (FASB) began working on a project to reexamine the generally accepted accounting procedure for income taxes in September 1982. Accounting Principles Board Opinion 11 ("APB 11"), issued in 1967, faced criticism and concerns about the inconsistencies in its amendments and interpretations. In addition, problems created by new tax depreciation methods and changes in accounting for income taxes in other countries were making APB 11 outdated. In 1988, the FASB issued Statement of Financial Accounting Standards No. 96 "Accounting for Income Taxes" ("SFAS 96") to address the increased complexity and significance of deferred taxes in the balance sheet. However, because of its complex scheduling process and conservative tax asset provisions, SFAS 96 soon became a source of controversy among businesses, CPA firms, professional organizations, and industry trade groups. In response to the criticism, the FASB deferred the required implementation date of SFAS 96 three times (SFAS 100, 103, and 108) and began developing a new standard which would address not only criticism of APB Opinion 11 but also the controversy surrounding SFAS 96. The new standard, SFAS 109, "Accounting for Income Taxes," became effective for periods beginning after December 15, 1992.

The objective of accounting for income taxes is the recognition and presentation in the financial statements of:

- Taxes currently payable or refundable

- Deferred tax assets and liabilities for the future tax consequences of events that have been recognized in the financial statements or tax returns.

Deferred taxes reflect the future tax consequences of events already recognized in either the financial statements or tax returns. SFAS 109 uses the balance sheet approach, also referred to as the liability method, to determine deferred taxes. This method, first introduced in SFAS 96, differs from APB 11, which used the income statement approach. SFAS 109 also requires a deferred tax asset to be recognized for deductible temporary differences and operating loss and tax credit carryforwards using the applicable tax rate. 
The income statement approach recognizes deferred taxes on the temporary timing differences between pretax accounting income and taxable income each year. Temporary timing differences are those differences between accounting and taxable income which will ultimately reverse. For example, intangible drilling costs for a successful well are expensed when paid for tax purposes, but capitalized and depreciated for accounting purposes. If we assume intangible drilling costs of $\$ 100,000$ on one well was the only timing difference, and this cost was depreciated $\$ 20,000$ per year for accounting purposes; there would be an $\$ 80,000$ temporary timing difference in year one, as taxable income would be less than accounting income. This timing difference would reverse $\$ 20,000$ each year as the intangible drilling cost is depreciated for accounting purposes with no deduction for tax purposes. At the end of the fifth year, the timing difference would be completely reversed.

The liability approach recognizes deferred taxes on the temporary differences between the finaricial and tax bases of assets and liabilities. Both the deferred tax liability and the deferred tax asset must be measured by use of the applicable tax rate. The applicable tax rate is the enacted tax rate to be applied to the last dollar of taxable income for the year when the liability is expected to be settled or the assets recovered. A single flat tax rate may be used for companies for which graduated rates are not a significant factor. A deferred tax asset is recognized for existing alternative minimum tax credit carryforwards for tax purposes. When computing deferred tax assets and/or liabilities, if there is a change in the tax rate or tax law, the deferred tax assets and/or liabilities should be adjusted in the period that includes the enactment date. To the extent deferred tax balances are adjusted for the effects of such changes, income tax expense or benefit from continuing operations is charged or credited. Using the example from the preceding paragraph, the financial statement basis of the intangible drilling cost in year one would be $\$ 80,000$ ( $\$ 100,000$ less $\$ 20,000$ depreciation), while there would be no basis for tax purposes because the costs were totally deducted. Deferred taxes would be provided for the $\$ 80,000$ difference by use of enacted tax rates. Deferred taxes would be adjusted each year until the difference between the financial accounting and tax bases was fully eliminated at the end of year five.

Once deferred tax assets and liabilities relating to the future tax consequences of temporary differences and carryforwards have been measured, the deferred tax provision or benefit is based on the net change in a deferred tax balance during the year. The income tax expense or benefit for the period is derived from the total tax currently payable or refundable and the deferred tax expense or benefit.

As stated earlier, SFAS 109 became effective for fiscal years beginning after December 15, 1992. There were two transition options available when adopting SFAS 109: prospective or retroactive application. A company could elect to restate the financial statements for any number of consecutive prior years (retroactive application) or report a cumulative effect adjustment below "income from continuing operations" (prospective application).

For 1993 and 1994, all of the FRS companies have reported taxes in accordance with SFAS 109. For 1992, seventeen FRS reporting companies had adopted the provisions of SFAS 109, which resulted in a net $\$ 163$ million benefit to their 1992 reported earnings. The remaining eight FRS reporting companies adopted SFAS 109 in the first quarter of 1993, and they have reported a $\$ 671$ million benefit to 1993 reported earnings. Of the eight companies which had not adopted SFAS 109 in 1992, five reported under APB 11 and three reported in accordance with SFAS 96.

\section{Corporate Acquisitions}

Under FRS reporting rules, no acquisitions are accounted for under the pooling of interest method. This is because, under the pooling method, the financial statements do not reflect such transactions as new investment, since the historical financial statements are restated. One of the objectives of the FRS is to track new investment activities.

For FRS reporting purposes, acquisitions accounted for as pooling for annual report purposes must be reflected in the FRS filing under a modified purchase method. All purchase accounting rules are followed, except that the assets of the acquired company are not revalued but are recorded at their book values as stated on the acquired company's books.

\section{Full Cost and Successful Efforts Accounting Methods}

FRS reporting companies are permitted to choose between two accounting methods, "full cost" and "successful efforts," to account for their exploration and production activities. All but two of the FRS companies use the successful efforts method. The main difference between the two methods is the treatment of dry exploratory well cost. 
Under full cost, the cost of a dry exploratory well is capitalized and then amortized to the income statement over the production life of successful wells. Thus, the costs of both dry and successful wells are capitalized and reflected in the balance sheet as part of producing properties.

Under successful efforts, the cost of a dry exploratory well is written off to expense in the year drilling is determined to be unsuccessful. There is no capitalized cost of such dry exploratory wells carried on the balance sheet.

In comparison to the successful efforts method, the full cost method will: (1) show less volatility of earnings, since the cost of unsuccessful wells is amortized over many years; (2) show a higher balance in accumulated property, plant, and equipment (PP\&E), since the account contains the costs of all wells drilled, including dry exploratory wells; (3) usually show higher earnings during years of intense exploratory activity when a number of dry wells are encountered; and (4) show the same cumulative earnings over a long period of years, since eventually all costs will be amortized to the income statement. These effects are minimized if the firm is large, since the exploratory activities of a large firm are usually smaller relative to total production operations than they are in a small production firm.

Usually, the precise effect of using one method over the other cannot be determined. However, one large firm switched from full cost to successful efforts in 1975 and restated 1973 and 1974 data to the successful efforts method. Thus, we have available the impact of this conversion on their comparative net income, net PP\&E, and return on net PP\&E for 1973 and 1974 (see Table A3). Since twenty-two of the FRS companies presently use successful efforts accounting, comparability problems are inconsequential.

\section{Inventory Accounting - LIFO Versus FIFO}

The Last In-First Out (LIFO) and the First In-First Out (FIFO) inventory methods are used most often in the preparation of the financial statements of industrial enterprises.

Under FIFO, the balance sheet valuation of inventory is based upon the most recent prices paid for the physical units on hand at year's end, and the income statement reflects the cost of units sold at the oldest unit cost. In periods of rapidly rising prices, the income statement reflects higher profits than would be reflected if the units sold were priced at current replacement cost or under the LIFO method.

Under LIFO, the balance sheet valuation of inventory is based on the prices paid for the first units of each major type of inventory ever purchased. For example, crude oil could be carried at $\$ 10$ per barrel, an amount which, of course, vastly understates the value of the inventory in terms of its replacement cost. The income statement reflects the cost of units sold at the most recent prices paid for the number of units sold. Thus, cost of goods sold reflects nearly a replacement cost amount, and profits are lower than under the FIFO method.

Since either method is permitted under the Federal tax laws, most companies use LIFO for operations subject to U.S. taxation because earnings and, hence, taxes are lower under this method. By 1979, most FRS reporting companies were using primarily the LIFO inventory method. Most analysts probably would agree that LIFO is the preferable method, since the income statement is more realistic than with FIFO. However, its disadvantage is that the balance sheet's inventory figure is understated, and hence the stockholders' equity amount is correspondingly understated.

Table A3. A Comparison Between Full Cost and Successful Efforts Accounting Methods

\begin{tabular}{l|r|r}
\hline \multicolumn{1}{c|}{ Years } & Full Cost & Successful Efforts \\
\hline 1973 & & \\
Net Income (dollars) & $1,292,400$ & $1,243,300$ \\
Net PP\&E (dollars) & $8,476,700$ & $7,511,300$ \\
Net Income/PP\&E (percent) & 15.25 & 16.70 \\
1974 & & \\
Net Income (dollars) & $1,586,400$ & $1,544,700$ \\
Net PP\&E (dollars) & $9,593,300$ & $8,563,500$ \\
Net Income/PP\&E (percent) & 16.54 & 17.98 \\
\hline
\end{tabular}

Source: Texaco, Inc., 1974 and 1977 Annual Report and Statistical Supplements. 
In 1994, four FRS companies reported liquidation profits or losses. The 1994 aggregate liquidation profits increased the reporting companies' operating income by $\$ 23,4$ million, an amount which represented 0.1 percent of their aggregate operating income. This compares to a $\$ 96$ million increase in 1993 and a $\$ 7$ million increase in 1992, amounts which represented 0.4 and 0.1 percent, respectively, of aggregate operating income for those years.

\section{Foreign Currency Translations}

In December 1981, the Financial Accounting Standards Board (FASB) issued Statement No. 52, "Foreign Currency Translations," which superseded FASB-8, "Accounting for the Translation of Foreign Currency Transactions and Foreign Currency Financial Statements." FASB-52 covers the translation of the foreign currency financial statements for the purposes of the consolidation, combination, or reporting by the equity method, and the translation of foreign currency transactions. The new statement required that assets, liabilities, and operations of an entity be stated in the currency of the primary economic environment in which the entity operates (termed, the "functional currency"). If a foreign entity has not kept its financial records in the functional currency, remeasurement is required prior to translation. Any gain or loss on remeasurement is recognized in current net income. The assets and liabilities of the foreign entity are translated frorit its functional currency to the reporting currency at the current rate of exchange.

Under FASB-52, gain or loss on the translation of foreign currency financial statements is shown as a separate component of stockholders' equity, whereas, under FASB-8, all non-monetary balance sheet items were translated at the historical rate of exchange. Thus, the change to FASB-52, which uses the current rate of exchange, had the most significant impact on inventories and fixed assets. With respect to the income statement, FASB-52 requires that only gains or losses from foreign currency transactions be included.

As Table A4 below indicates, foreign currency translation losses increased stockholders' equity by 1.2 percent, while foreign currency transaction gains increased pretax income by 1.0 percent in 1994.

\section{FRS Database History}

The Form EIA-28, Financial Reporting System (FRS), database has existed in three formats during its 20-year history. In addition, there have been minor, periodic adjustments since 1987. The most noteworthy was the change from a Statement of Sources and Uses of Funds to a Statement of Cash Flows, effective in the 1986 reporting year. The first version of the Form ELA-28 and its database covered years 1974-1980. The second version covered years 1981-1986. The third covered years 1987-1992. The fourth version begins with the 1993 reporting year and is approved through the 1995 reporting year. The current version was changed by the addition of the Former Soviet Union and Eastern Europe as a new. geographical reporting area.

The first full reporting year for the first version of the form was 1977. It consisted of 47 separate schedules containing 8,775 data elements and was 136 pages long. ${ }^{212}$ This version of the database contained a significant amount of detail at the consolidated level, at each line of business, and in the breadth of operating statistics. However, not all of the collected data were loaded into the database. About 1,000 elements were not unique to individual companies-such as joint venture information-and were maintained only in their hard copy format.

In 1982 (for the 1981 reporting year) the form was shortened by 72 percent, to 2,468 elements. The format was still the same, with data collected at the consolidated level, four energy lines of business (petroleum, coal, nuclear, and other energy) and nonenergy. The 1981-1986 form consisted of 19 schedules and was 35 pages long. Although data were still collected by each line of business, most of the decline was at the line-of-business level, where more than 81 percent of the form was eliminated, compared with a 58-percent decline at the consolidated level.

In 1988 (for the 1987 reporting year) the form was shortened by another 33 percent, to 1,650 elements. The consolidated level was shortened by 32 percent, primarily by combining other energy with nuclear energy. Petroleum data declined by 10 percent, coal by 74 percent, and separate income statement schedules for the remaining lines of business (coal, nuclear and other energy, and nonenergy) were eliminated altogether (although income statements for each of these lines of business were incorporated into Schedule 5110, Consolidating Statement of Income). The form currently has 14 schedules, and is 27 pages long.

\footnotetext{
${ }^{212}$ In order to extend the range of the data back through 1974, an abbreviated version of the form was collected for the years 1974 through 1976. Almost 2,900 data elements (one-third of the total) were collected for each of these years, and consisted primarily of summary data from 26 of the 47 schedules.
} 
Table A4. The Impact of FASB-52, Foreign Currency Translations, on Stockholders' Equity and Pretax Income, 1982-1994

\begin{tabular}{|c|c|c|c|c|c|c|c|}
\hline Y & lear & $\begin{array}{l}\text { Translation } \\
\text { Gain/Losses }\end{array}$ & $\begin{array}{c}\text { Stockholders' } \\
\text { Equity }\end{array}$ & $\begin{array}{c}\text { Percent of } \\
\text { Stockholders' } \\
\text { Equity }\end{array}$ & $\begin{array}{l}\text { Transactlon } \\
\text { Gains/Losses }\end{array}$ & $\begin{array}{l}\text { Pretax } \\
\text { Income }\end{array}$ & $\begin{array}{l}\text { Percent of } \\
\text { Pretax } \\
\text { Income }\end{array}$ \\
\hline & & \multicolumn{2}{|c|}{ (million dollars) } & & \multicolumn{2}{|c|}{ (million dollars) } & \\
\hline 1982 & $\ldots \ldots$ & $-1,764$ & 183,933 & -1.0 & -111 & 45,157 & -0.2 \\
\hline 1983 & $\ldots \ldots$ & $-1,253$ & 192,509 & -0.7 & 35 & 47,420 & 0.1 \\
\hline 1984 & $\ldots \ldots$ & $-1,683$ & 176,461 & -1.0 & -44 & 47,609 & -0.1 \\
\hline 1985 & $\ldots \ldots$ & 399 & 165,457 & 0.2 & 176 & 43,573 & .0 .4 \\
\hline 1986 & $\ldots \ldots$ & 1,786 & 164,601 & 1.1 & 543 & 20,564 & 2.6 \\
\hline 1987 & $\ldots \ldots$ & 3,425 & 165,458 & 2.1 & 176 & 25,006 & 0.7 \\
\hline 1988 & $\ldots \ldots$ & -495 & 164,832 & -0.3 & 89 & 34,285 & 0.3 \\
\hline 1989 & $\ldots$. & -465 & 160,638 & -0.3 & 142 & 32,281 & 0.4 \\
\hline 1990 & $\ldots \ldots$ & 1,918 & 167,060 & 1.1 & 135 & 37,489 & 0.4 \\
\hline 1991 & $\ldots \ldots$ & 101 & 167,574 & 0.1 & -25 & 25,120 & -0.1 \\
\hline 1992 & $\ldots \ldots$ & $-3,341$ & 157,295 & -2.1 & 375 & 22,542 & 1.7 \\
\hline 1993 & $\ldots \ldots$ & -637 & 161,769 & -0.4 & 170 & 24,777 & 0.7 \\
\hline 1994 & $\ldots .$. & 1,912 & 165,689 & 1.2 & 280 & 29,592 & 1.0 \\
\hline
\end{tabular}

Source: Energy Information Administration, Form ElA-28. 



\section{Appendix B}

\section{Detailed Statistical Tables}

Table B1. Selected U.S. Operating Statistics for FRS Companies and U.S. Industry, 1993 and 1994

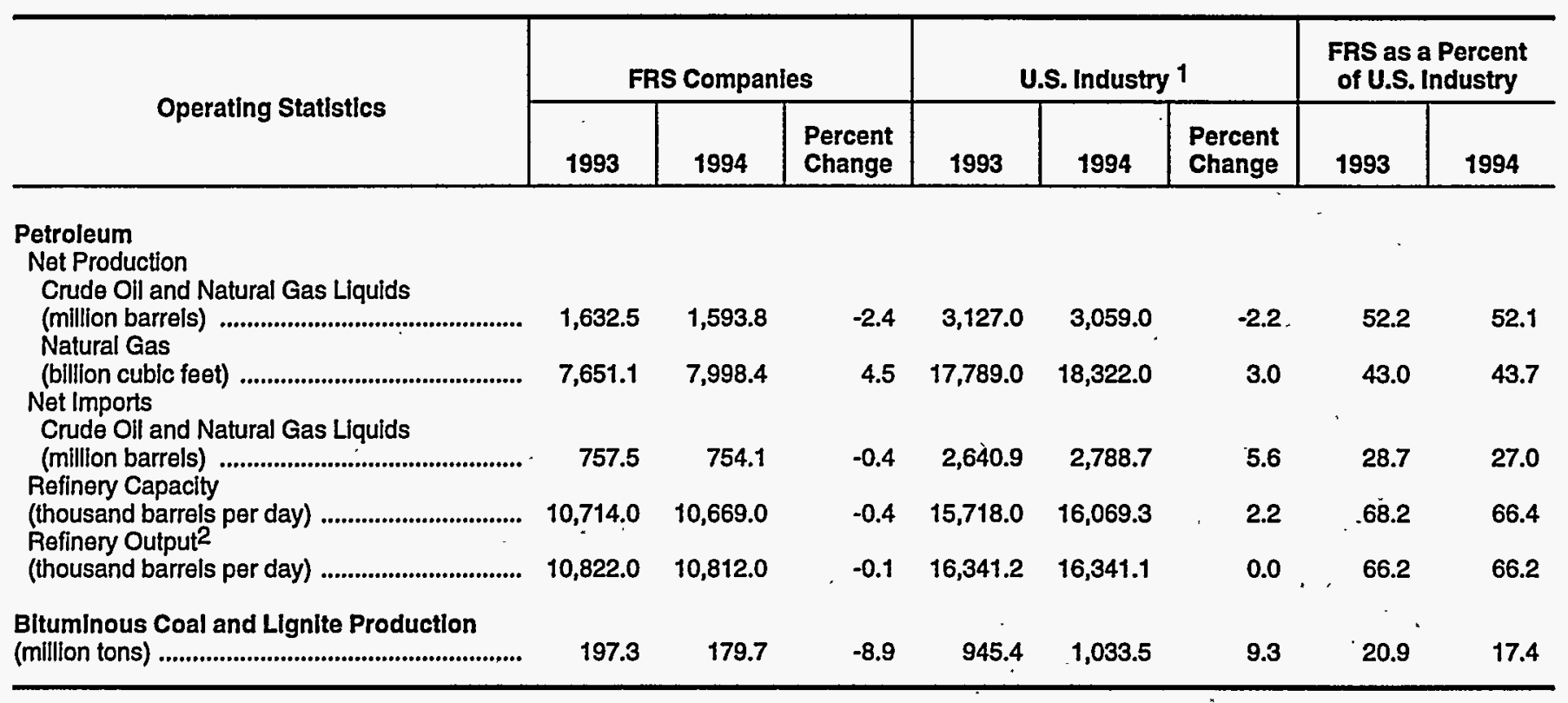

1 U.S. area is defined to include the 50 States, District of Columbia, U.S. Virgin Islands, and Puerto Rico.

2 For FRS companies, includes refinery output at own refineries for own account and at others' refineries for own account.

Note: The data for total U.S. production of crude oil and natural gas liquids and natural gas (dry) utilized in this report are taken from Energy Information Administration, Form EIA-23, see U.S. Crude Oil, Natural Gas, and Natural Gas Liquids Reserves 1994 Annual Report (October 1995). This source is utilized in order to preserve consistency between production reported in the context of oil and gas reserves and reserve additions and production reported elsewhere in this report. However, the official Energy Information Administration U.S. totals for crude oil and natural gas plant production are 3,155.4 million barrels in 1994 and 3,225.1 million barrels in 1993 (see Energy Information Administration, Petroleum Supply Annual 1994, Volume 1 (May 1995), p. 2). For dry natural gas production, the official Energy Information-Administration U.S. totals are 18,853 billion cubic feet in 1994 and 18,244 billion cubic feet in 1993 (see Energy Information Administration, Natural Gas Monthly, September 1995, p. 8).

Sources: Industry data - Petroleum net production: Energy Information Administration, Form EIA-23, see U.S. Crude Oil, Natural Gas, and Natural Gas Liquids Reserves, 1994 Annual Report (October 1995). Net imports: data compiled for the International Energy Agency by the Petroleum Supply Division, Office of Oil and Gas, Energy Information Administration. Refinery capacity and refinery outpur: Energy Information Administration, Forms EIA-820 and EIA-810; see Petroleum Supply Annual, 1993 and 1994. Coal production: Energy Information Administration, Form ElA-7A; see Coal Industry Annual 1994 (October 1995). 
Table B2. Selected U.S. Operating Statistics for FRS Companies and.U.S. Industry, 1988-1994

\begin{tabular}{|c|c|c|c|c|c|c|c|}
\hline Operating Statistics & 1988 & 1989 & 1990 & 1991 & 1992 & 1993 & 1994 \\
\hline \multicolumn{8}{|l|}{$\begin{array}{l}\text { Petroleum } \\
\text { Net Production } \\
\text { Crude Oil and Natural Gas Liquids } \\
\text { (million barrels) }\end{array}$} \\
\hline $\begin{array}{l}\text { FRS companies } \\
\text { U.S. Industry } 1 \\
\text { FRS as a percent of }\end{array}$ & $\begin{array}{l}2,102.1 \\
3,565.0\end{array}$ & $\begin{array}{l}1,911.1 \\
3,317.0\end{array}$ & $\begin{array}{l}1,814.0 \\
3,237.0\end{array}$ & $\begin{array}{l}1,818.1 \\
3,266.0\end{array}$ & $\begin{array}{l}1,750.2 \\
3,219.0\end{array}$ & $\begin{array}{l}1,632.5 \\
3,127.0\end{array}$ & $\begin{array}{l}1,593.8 \\
3,059.0\end{array}$ \\
\hline $\begin{array}{l}\text { U.S. Industry } \\
\text { Natural Gas } \\
\text { (billion cubic feet) }\end{array}$ & 59.0 & 57.6 & 56.0 & 55.7 & 54.4 & 52.2 & 52.1 \\
\hline $\begin{array}{l}\text { FRS companies } \\
\text { U.S. Industry }{ }^{1} \\
\text { FRS as a percent of }\end{array}$ & $\begin{array}{r}7,627.3 \\
16,670.0\end{array}$ & $\begin{array}{r}7,480.7 \\
16,983.0\end{array}$ & $\begin{array}{r}7,578.2 \\
17,233.0\end{array}$ & $\begin{array}{r}7,509.5 \\
17,202.0\end{array}$ & $\begin{array}{r}7,877.7 \\
17,423.0\end{array}$ & $\begin{array}{r}7,651.1 \\
17,789.0\end{array}$ & $\begin{array}{r}7,998.4 \\
18,322.0\end{array}$ \\
\hline $\begin{array}{l}\text { U.S. Industry } \\
\text { Net Imports } \\
\text { Crude Oil and Natural Gas Liquids } \\
\text { (million barrels) }\end{array}$ & 45.8 & 44.0 & 44.0 & 43.7 & 45.2 & 43.0 & 43.7 \\
\hline 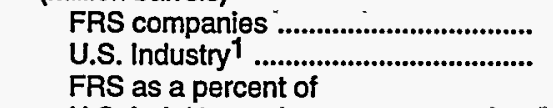 & $\begin{array}{r}906.4 \\
2,003.0\end{array}$ & $\begin{array}{r}834.3 \\
2,289.3\end{array}$ & $\begin{array}{r}975.2 \\
2,324.7\end{array}$ & $\begin{array}{r}917.9 \\
2,243.7\end{array}$ & $\begin{array}{r}868.8 \\
2,383.0\end{array}$ & $\begin{array}{r}757.5 \\
2,640.9\end{array}$ & $\begin{array}{r}754.1 \\
2,788.7\end{array}$ \\
\hline $\begin{array}{l}\text { U.S. Industry } \\
\text { Refinery Capacity } \\
\text { (thousand barrels per day) }\end{array}$ & 45.3 & 36.4 & 41.9 & 40.9 & 36.5 & 28.7 & 27.0 \\
\hline 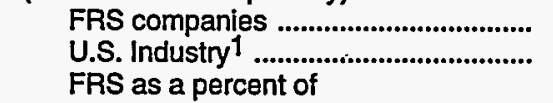 & $\begin{array}{l}12,281.0 \\
16,285.0\end{array}$ & $\begin{array}{l}11,489.0 \\
16,238.0\end{array}$ & $\begin{array}{l}11,372.0 \\
16,430.4\end{array}$ & $\begin{array}{l}11,203.0 \\
16,452.6\end{array}$ & $\begin{array}{l}10,952.0 \\
15,804.4\end{array}$ & $\begin{array}{l}10,714.0 \\
15,718.0\end{array}$ & $\begin{array}{l}10,669.0 \\
16,069.3\end{array}$ \\
\hline $\begin{array}{l}\text { U.S. Industry } \\
\text { Refinery Output } 2 \\
\text { (thousand barrels per day) }\end{array}$ & 75.4 & 70.8 & 69.2 & 68.1 & 69.3 & 68.2 & 66.4 \\
\hline $\begin{array}{l}\text { FRS companies } \\
\text { U.S. Industry } 1 \\
\text { FRS as a percent of }\end{array}$ & $\begin{array}{l}12,033.0 \\
15,426.0\end{array}$ & $\begin{array}{l}11,413.0 \\
15,654.6\end{array}$ & $\begin{array}{l}11,312.0 \\
15,911.2\end{array}$ & $\begin{array}{l}11,122.0 \\
15,872.2\end{array}$ & $\begin{array}{l}10,994.0 \\
15,932.0\end{array}$ & $\begin{array}{l}10,822.0 \\
16,341.2\end{array}$ & $\begin{array}{l}10,812.0 \\
16,341.1\end{array}$ \\
\hline 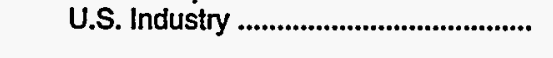 & 78.0 & 72.9 & 71.1 & 70.1 & 69.0 & 66.2 & 66.2 \\
\hline \multicolumn{8}{|l|}{$\begin{array}{l}\text { Bituminous Coal arid Lignite } \\
\text { Production } \\
\text { (million tons) }\end{array}$} \\
\hline $\begin{array}{l}\text { FRS companies } \\
\text { U.S. Industry } 1 \\
\text { FRS as a percent of }\end{array}$ & $\begin{array}{l}285.3 \\
950.3\end{array}$ & $\begin{array}{l}286.9 \\
980.7\end{array}$ & $\begin{array}{r}282.0 \\
1,029.1\end{array}$ & $\begin{array}{l}289.6 \\
996.0\end{array}$ & $\begin{array}{l}251.9 \\
997.5\end{array}$ & $\begin{array}{l}197.3 \\
945.4\end{array}$ & $\begin{array}{r}179.7 \\
1,033.5\end{array}$ \\
\hline 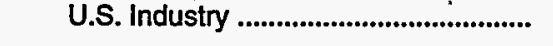 & 30.0 & 29.3 & 27.4 & 29.1 & 25.3 & 20.9 & 17.4 \\
\hline
\end{tabular}

1 U.S. area is defined to include the 50 States, District of Columbia, U.S. Virgin Islands, and Puerto Rico.

2 For FRS companies, includes refinery output at own refineries for own account and at others' refineries for own account.

Note: The data for total U.S. production of crude oil and natural gas liquids and natural gas (dry) utilized in this report are taken from Energy Information Administration, Form ElA-23, see U.S. Crude Oil, Natural Gas, and Natural Gas Liquids Reserves 1994 Annual Report (October 1995). This source is utilized in order to preserve consistency between production reported in the context of oil and gas reserves and reserve additions and production reported elsewhere in this report. However, the official Energy Information Administration U.S. totals for crude oil and natural gas plant production are 3,155.4 million barrels in 1994 and 3,225.1 million barrels in 1993 (see Energy Information Administration, Petroleum 1995), p. 2). For dry natural gas production, the official Energy Information Administration U.S. totals are 18,853 billion cublc feet in 1994 and 18,244 billion cubic feet in 1993 (see Energy Information Administration, Natural Gas Monthly, September 1995, p: 8).

Sources: Industry data - Petroleum net production: Energy Information Administration, Form EIA-23, see U.S. Crude Oil, Natural Gas, and Natural Gas Liquids Reserves, 1994 Annual Report (October 1995). Net imports: data compiled for the International Energy Agency by the Petroleum Supply Division, Office of Oil and Gas, Energy Information Administration. Refinery capacity and refinery output: Energy Information Administration, Forms EIA-820 and EIA-810; see Petroleum Supply Annual, 1993 and 1994. Coal production: Energy Information Administration, Form ElA-7A; see Coal Industry Annual 1994 (October 1995). 
Table B3. A Comparison of Selected Financial Items for FRS Companies and the S\&P 400, 1994 and Percent Change from 1993

\begin{tabular}{|c|c|c|c|c|}
\hline \multirow{2}{*}{ Selected Financial Items } & \multicolumn{2}{|c|}{ FRS Companies } & \multicolumn{2}{|c|}{ S\&P 400} \\
\hline & $\begin{array}{c}1994 \\
\text { (billion dollars) }\end{array}$ & $\begin{array}{l}\text { Percent Change } \\
\text { from } 1993\end{array}$ & $\begin{array}{c}1994 \\
\text { (billion dollars) }\end{array}$ & $\begin{array}{l}\text { Percent Change } \\
\text { from } 1993\end{array}$ \\
\hline \multicolumn{5}{|l|}{ Income Statement } \\
\hline 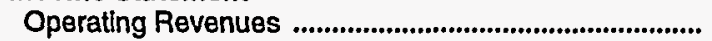 & 446.6 & -0.3 & $2,915.9$ & 5.6 \\
\hline Operating Expenses & -416.5 & -1.5 & $-2,631.9$ & 4.5 \\
\hline Operating Income & 30.1 & 19.9 & 284.0 & 17.3 \\
\hline Other Income ${ }^{1}$ & -2.9 & $(2)$ & -43.3 & $(2)$ \\
\hline Income Taxes & -10.6 & 16.3 & -87.8 & 40.3 \\
\hline Net Income & 16.5 & 6.8 & 152.9 & 93.7 \\
\hline \multicolumn{5}{|l|}{ Cash Flows from Operations 3} \\
\hline Net Income & 16.5 & 6.8 & 152.9 & 93.7 \\
\hline Other Items, Net 4 & 31.8 & -8.5 & 139.9 & -26.7 \\
\hline 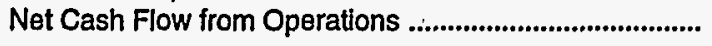 & 48.3 & -3.8 & 292.8 & 8.5 \\
\hline \multicolumn{5}{|l|}{ Cash Flows from Investing Activities 3} \\
\hline 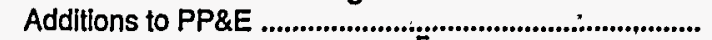 & -37.5 & -1.5 & -191.0 & 11.8 \\
\hline 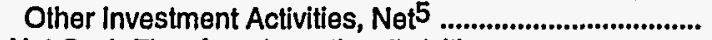 & 2.5 & -65.3 & -63.0 & 60.0 \\
\hline Net Cash Flow from Investing Activities .............................. & -35.0 & 13.4 & -254.0 & 20.8 \\
\hline \multicolumn{5}{|l|}{ Cash Flows from Financing Activities 3} \\
\hline 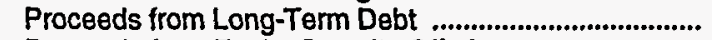 & 12.5 & -34.1 & 165.1 & -10.3 \\
\hline Proceeds from Equity Security Offerings .......................... & 2.6 & 21.8 & 23.0 & -12.0 \\
\hline 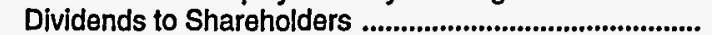 & -14.9 & 9.9 & -62.0 & 1.3 \\
\hline Reductions in Long-Term Debt ....................................... & -13.8 & -34.1 & -154.0 & -13.2 \\
\hline 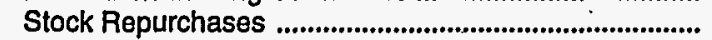 & -1.0 & 96.5 & -30.0 & 11.4 \\
\hline 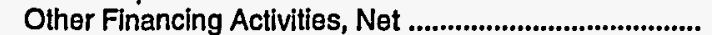 & -1.1 & -73.4 & 22.0 & 201.8 \\
\hline Net Cash Flow from Financing Activities ............................ & -15.7 & -12.7 & -35.9 & -25.1 \\
\hline Effect of Exchange Rate Changes on Cash ................ & 0.1 & $\left({ }^{2}\right)$ & 1.2 & -155.9 \\
\hline Increase (Decrease) in Cash and Cash Equivalents .. & -2.2 & $\left({ }^{2}\right)$ & 4.0 & $(2)$ \\
\hline
\end{tabular}

1 "Other Income" includes other revenue and expense, discontinued operations, extraordinary items, and accounting changes.

2 Not meaningful.

3 Items that add to cash are positive, and items that use cash are shown as negative values.

4 "Other Items, Net" includes: DD\&A, deferred taxes, dry hole expense, minority interest, recognized undistributed earnings/(losses) of unconsolidated affiliates, (gain)/loss on disposition of PP\&E, changes in operating assets and liabilities, and other noncash items, excluding net change in short-term debt; other cash items, net.

5 "Other Investment Activities, Net" includes additions to investments and advances and proceeds from disposals of PP\&E.

Sources: Standard \& Poor's (S\&P) 400 data - Compustat, Inc. FRS companies' data - Energy Information Administration, Form EIA-28. 
Table B4. Consolidating Statement of Income for FRS Companies, 1994

(Million Dollars)

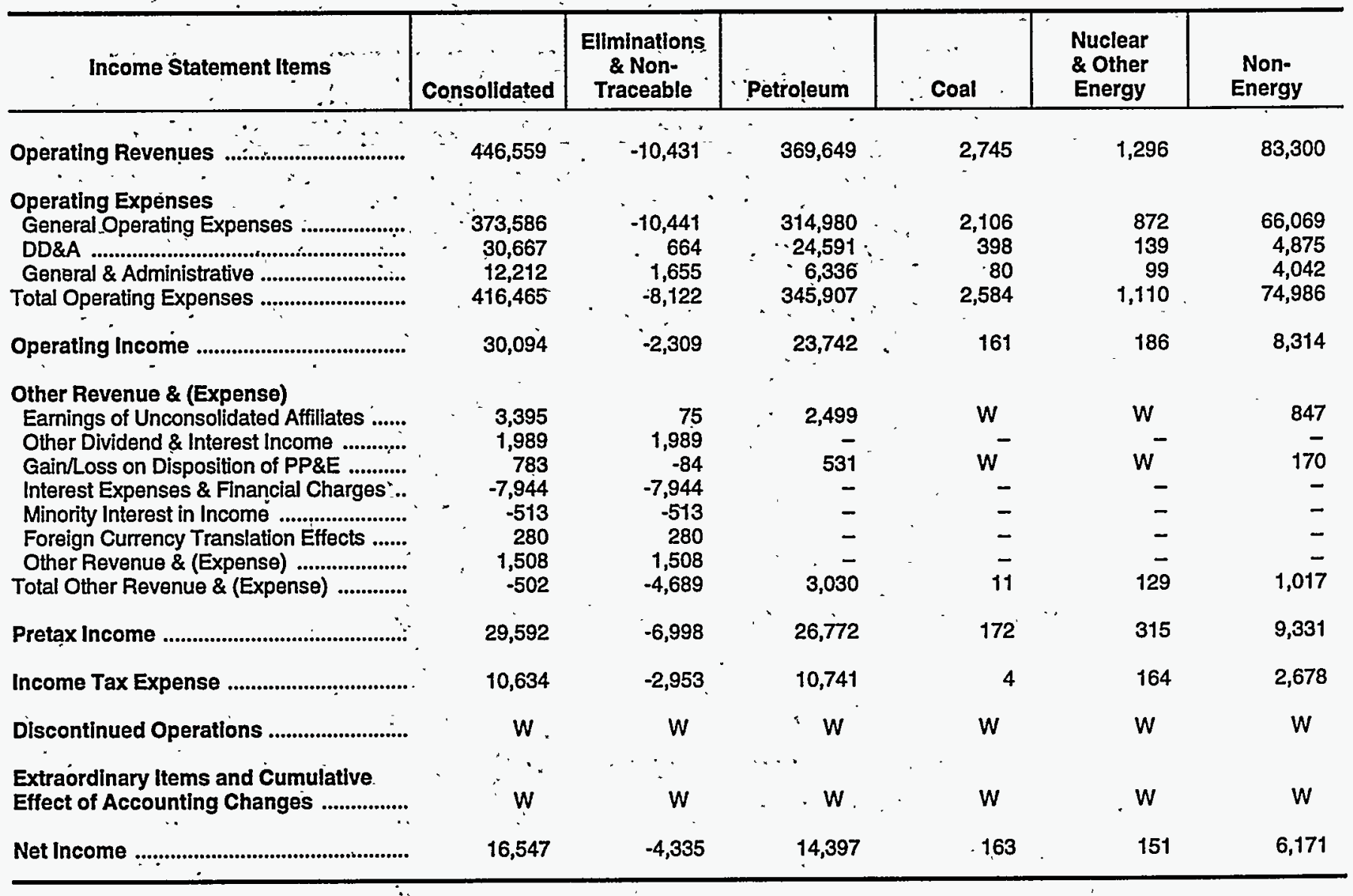

$\bar{W}=$ Not available.

$W=$ Data withheld to avoid disclosure.

Source: Energy Information Administration; Form EIA-28. 
Table B5. Consolidating Statement of Income for FRS Companies, U.S. and Foreign Petroleum Segments, 1994

(Million Dollars)

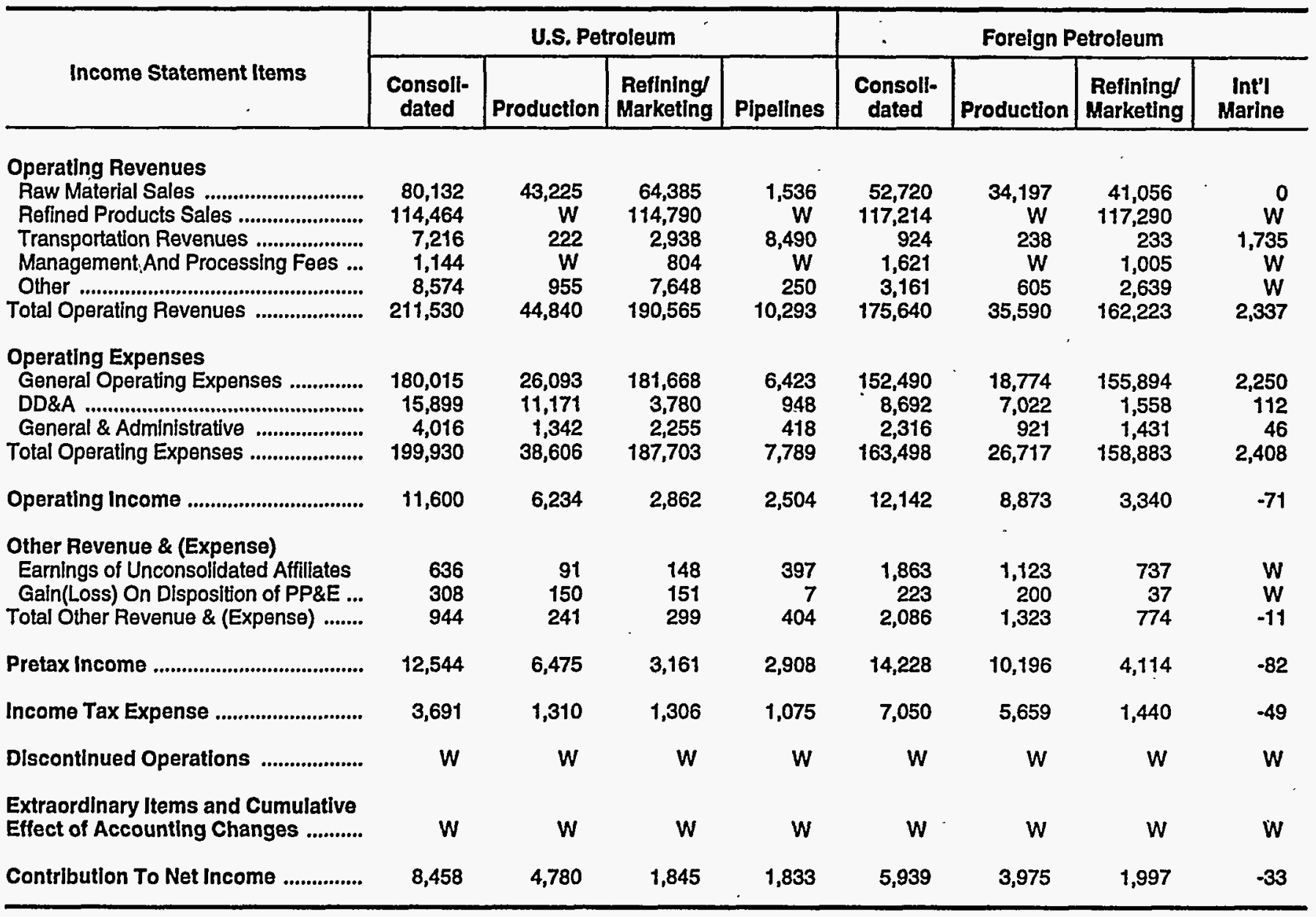

$W$ = Data withheld to avold disclosure.

Source: Energy Information Administration, Form EIA-28. 
Table B6. Profit Rates for Lines of Business and Petroleum Segments for FRS Companies, 1988-1994 (Percent)

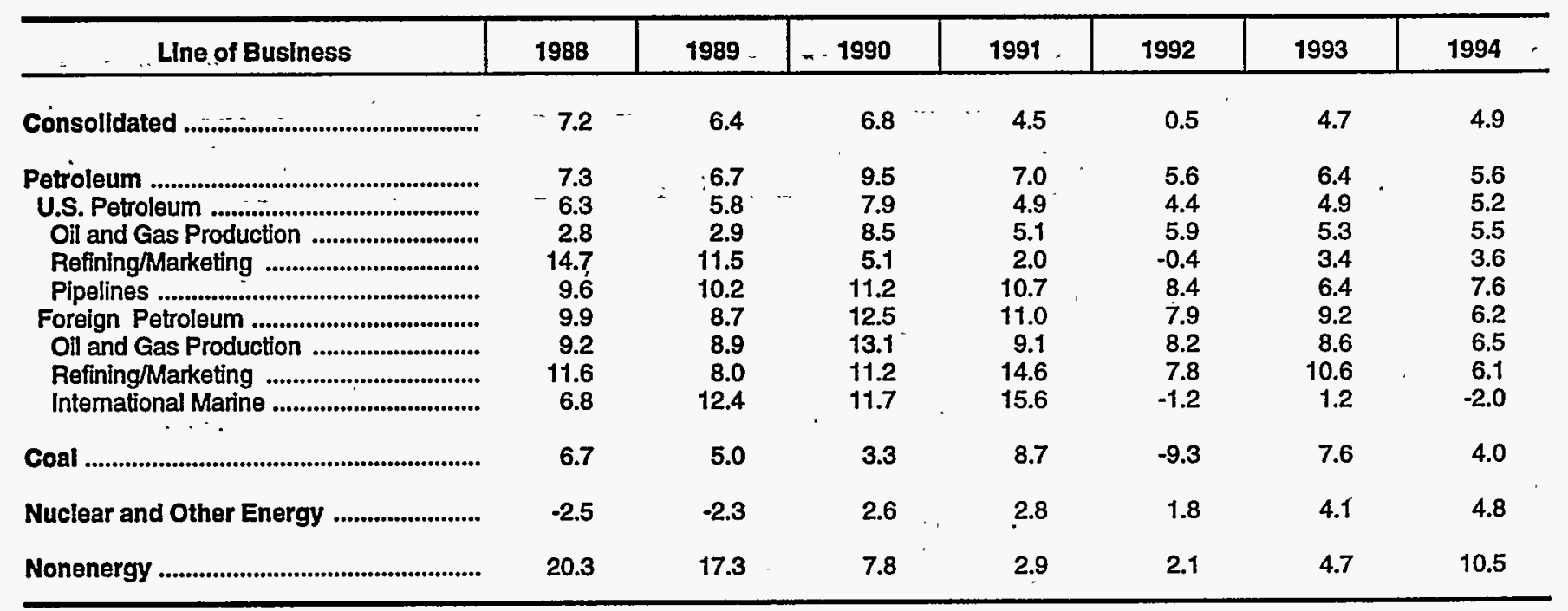

Note: Profit rate measured as contribution to net income/net investment in place.

Source: Energy information Administration, Form ElA-28. 
Table B7. Profit Rates for Petroleum Segments for FRS Companies Ranked by Total Energy Assets, 1992-1994

(Percent)

\begin{tabular}{|c|c|c|c|c|c|c|c|c|c|}
\hline \multirow{2}{*}{ Petroleum Segments } & \multicolumn{3}{|c|}{ Top Four } & \multicolumn{3}{|c|}{ Five Through Twelve } & \multicolumn{3}{|c|}{ All Other } \\
\hline & 1992 & 1993 & 1994 & 1992 & 1993 & 1994 & 1992 & 1993 & 1994 \\
\hline 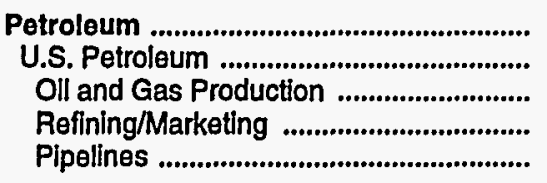 & $\begin{array}{r}8.1 \\
5.4 \\
6.8 \\
1.3 \\
16.2\end{array}$ & $\begin{array}{r}8.1 \\
4.5 \\
5.5 \\
1.5 \\
13.1\end{array}$ & $\begin{array}{r}6.5 \\
5.0 \\
5.9 \\
2.1 \\
17.1\end{array}$ & $\begin{array}{l}4.1 \\
4.6 \\
5.5 \\
0.6 \\
6.6\end{array}$ & $\begin{array}{l}4.9 \\
5.2 \\
4.4 \\
7.4 \\
4.8\end{array}$ & $\begin{array}{l}5.0 \\
5.5 \\
5.4 \\
5.4 \\
5.9\end{array}$ & $\begin{array}{r}2.5 \\
2.5 \\
5.0 \\
-4.9 \\
9.9\end{array}$ & $\begin{array}{r}5.1 \\
4.7 \\
6.9 \\
-0.2 \\
8.3\end{array}$ & $\begin{array}{l}4.1 \\
4.8 \\
4.9 \\
3.0 \\
8.6\end{array}$ \\
\hline 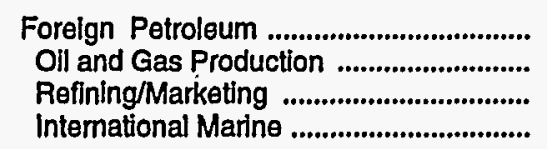 & $\begin{array}{r}10.7 \\
13.4 \\
8.0 \\
1.1\end{array}$ & $\begin{array}{l}11.2 \\
12.4 \\
10.5 \\
-0.1\end{array}$ & $\begin{array}{r}7.7 \\
9.9 \\
5.8 \\
-\mathbf{3 . 7}\end{array}$ & $\begin{array}{r}1.8 \\
0.9 \\
13.7 \\
-27.7\end{array}$ & $\begin{array}{r}3.9 \\
2.6 \\
15.6 \\
18.3\end{array}$ & $\begin{array}{r}3.4 \\
2.4 \\
10.6 \\
181.3\end{array}$ & $\begin{array}{r}2.4 \\
3.3 \\
-5.8 \\
16.7\end{array}$ & $\begin{array}{r}6.6 \\
6.8 \\
4.6 \\
19.4\end{array}$ & $\begin{array}{r}1.6 \\
1.1 \\
5.5 \\
-6.5\end{array}$ \\
\hline
\end{tabular}

Note: Profit rate measured as contribution to net income/net investment in place.

Source: Energy Information Administration, Form EIA-28. 
Table B8. A Comparison of Balance Sheet Items for FRS Companies and the S\&P 400, 1994 and Percent Change from 1993

\begin{tabular}{|c|c|c|c|c|}
\hline \multirow{2}{*}{ Balance Sheet Items } & \multicolumn{2}{|c|}{ FRS Companies } & \multicolumn{2}{|c|}{ S\&P 400} \\
\hline & $\begin{array}{c}1994 \\
\text { (billion dollars) }\end{array}$ & $\begin{array}{l}\text { Percent Change } \\
\text { from } 1993\end{array}$ & $\begin{array}{c}1994 \\
\text { (billion dollars) }\end{array}$ & $\begin{array}{c}\text { Percent Change } \\
\text { from } 1993\end{array}$ \\
\hline \multicolumn{5}{|l|}{ Assets } \\
\hline 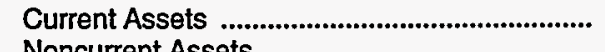 & 96.6 & 3.3 & 778.6 & 9.4 \\
\hline \multicolumn{5}{|l|}{ Noncurrent Assets } \\
\hline Gross & 624.1 & 2.7 & $1,958.5$ & 5.0 \\
\hline 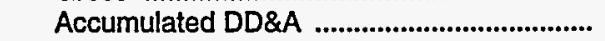 & -315.4 & 5.1 & -910.1 & 5.7 \\
\hline Net & 308.7 & 0.3 & $1,048.4$ & 4.4 \\
\hline Investments and Advances ............................. & 25.9 & 9.7 & 74.9 & 12.1 \\
\hline 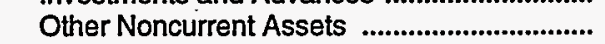 & 26.2 & -0.4 & $1,274.9$ & 2.5 \\
\hline Subtotal Noncurrent Assets ........................... & 360.8 & 0.8 & $2,398.2$ & 3.6 \\
\hline 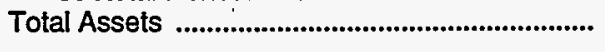 & 457.4 & 1.3 & $3,176.9$ & 4.9 \\
\hline \multicolumn{5}{|l|}{ Llabilities and Stockholders' Equity } \\
\hline \multicolumn{5}{|l|}{ Liabilities } \\
\hline Current Liabilities & 97.4 & 1.3 & 669.3 & -5.6 \\
\hline 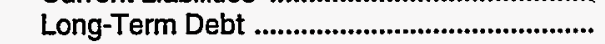 & 88.1 & -1.5 & 610.1 & 5.4 \\
\hline 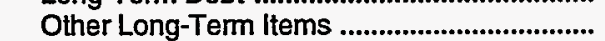 & 101.2 & 2.1 & 937.2 & 7.2 \\
\hline Minority Interest & 5.1 & 0.6 & 29.9 & 12.4 \\
\hline Subtotal Liabilities and Other Items ............. & 291.7 & 0.7 & $2,246.6$ & 2.6 \\
\hline \multicolumn{5}{|l|}{ Stockholders' Equity } \\
\hline Retained Earnings & 145.0 & 2.1 & 733.0 & 10.7 \\
\hline 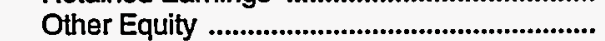 & 20.7 & 4.8 & 197.2 & 12.1 \\
\hline 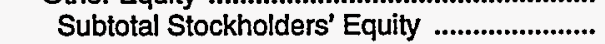 & 165.7 & 2.4 & 930.2 & 11.0 \\
\hline Total Liabilities and Stockholders' Equity ............ & 457.4 & 1.3 & $3,176.9$ & 4.9 \\
\hline
\end{tabular}

Sources: Standard \& Poor's (S\&P) 400 data - Compustat, Inc. FRS companies' data - Energy Information Administration, Form ElA-28. 
Table B9. Consolidated Balance Sheet for FRS Companies, 1988-1994

(Billion Dollars)

\begin{tabular}{|c|c|c|c|c|c|c|c|}
\hline Balance Sheet Items & 1988 & 1989 & 1990 & 1991 & 1992 & 1993 & 1994 \\
\hline Assets & & & & & & & \\
\hline \multicolumn{8}{|l|}{ Current Assets } \\
\hline $\begin{array}{l}\text { Cash \& Marketable Securities ................... } \\
\text { Trade Accounts and Notes Receivable ..... } \\
\text { Inventories }\end{array}$ & $\begin{array}{l}16.8 \\
43.7\end{array}$ & $\begin{array}{l}16.4 \\
45.4\end{array}$ & $\begin{array}{r}14.9 \\
56.6\end{array}$ & $\begin{array}{l}12.4 \\
47.2\end{array}$ & $\begin{array}{l}12.1 \\
44.6\end{array}$ & $\begin{array}{l}14.1 \\
41.7\end{array}$ & $\begin{array}{l}13.2 \\
45.8\end{array}$ \\
\hline Raw Materials \& Products ............................ & 26.9 & 26.2 & 28.0 & 27.0 & 26.2 & 23.7 & 22.9 \\
\hline Materials \& Supplies ................................... & 5.3 & 5.3 & 5.3 & 5.2 & 4.6 & 4.3 & 4.4 \\
\hline 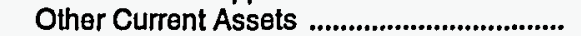 & 12.2 & .9 .2 & 10.5 & 9.2 & 10.4 & 9.6 & 10.2 \\
\hline 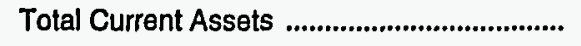 & 105.0 & 102.4 & 115.4 & 101.0 & 97.9 & 93.5 & 96.6 \\
\hline \multicolumn{8}{|l|}{$\begin{array}{l}\text { Non-current Assets } \\
\text { Property, Plant \& Equipment }\end{array}$} \\
\hline 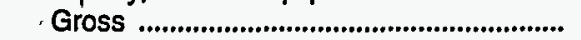 & 526.7 & 536.0 & 565.0 & 581.4 & 599.9 & 607.9 & 624.1 \\
\hline 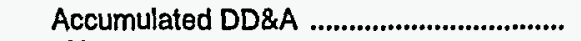 & 233.0 & 242.8 & . 262.5 & 275.9 & 290.2 & 300.0 & 315.4 \\
\hline 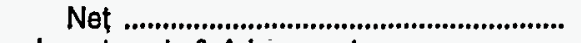 & 293.6 & 293.2 & 302.5 & 305.5 & 309.7 & 307.9 & 308.7 \\
\hline \multicolumn{8}{|l|}{ Investments \& Advances to } \\
\hline Unconsolidated Affiliates ............................ & 16.0 & 16.7 & 17.2 & 20.1 & 21.9 & 23.6 & 25.9 \\
\hline 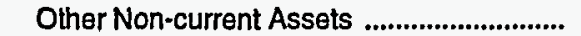 & 23.2 & 22.2 & 22.2 & 20.6 & 24.2 & 26.3 & 26.2 \\
\hline Total Non-current Assets ................................. & 332.8 & 332.1 & 341.8 & 346.2 & 355.7 & 357.8 & 360.8 \\
\hline Total Assets & 437.8 & 434.5 & 457.2 & 447.1 & 453.6 & 451.3 & 457.4 \\
\hline \multicolumn{8}{|l|}{ Llabllitles \& Stockholder's Equity } \\
\hline Liabilities & & & & & & & \\
\hline \multicolumn{8}{|l|}{ Current Liabilities } \\
\hline Trade Accounts \& Notes Payable ............. & 45.9 & 51.9 & 64.6 & 56.5 & 53.1 & 49.1 & 51.5 \\
\hline 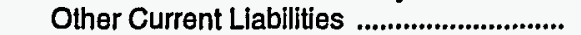 & 48.5 & 47.1 & 50.2 & 47.6 & 48.7 & 47.0 & 45.8 \\
\hline 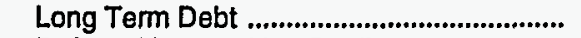 & 93.2 & 90.7 & 88.5 & 90.9 & 93.5 & 89.4 & 88.1 \\
\hline Deferred Income Tax Credits ......................... & 50.4 & 49.8 & 50.3 & 47.0 & 44.7 & 45.5 & 45.0 \\
\hline Other Deferred Credits & 11.8 & 10.9 & 12.3 & 12.2 & 16.5 & 15.9 & 16.8 \\
\hline 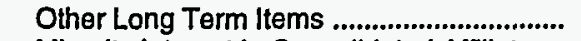 & 19.4 & 19.3 & 19.8 & 21.1 & 34.9 & 37.7 & 39.3 \\
\hline Minority Interest in Consolidated Affiliates & 3.6 & 4.2 & 4.4 & 4.2 & 4.8 & 5.0 & 5.1 \\
\hline 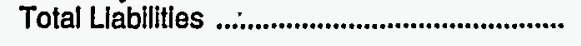 & 272.9 & 273.9 & 290.1 & 279.6 & 296.3 & 289.6 & 291.7 \\
\hline \multicolumn{8}{|l|}{ Stockholders' Equity } \\
\hline 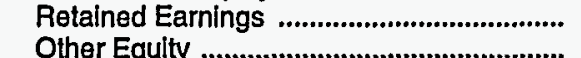 & 143.8 & $\begin{array}{r}140.9 \\
10.7\end{array}$ & 148.7 & $\begin{array}{r}148.9 \\
186\end{array}$ & $\begin{array}{r}139.2 \\
181\end{array}$ & 142.0 & $\begin{array}{r}145.0 \\
207\end{array}$ \\
\hline 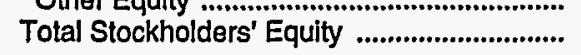 & 164.8 & 160.6 & 167.1 & $\begin{array}{r}18.6 \\
167.6\end{array}$ & $\begin{array}{r}18.7 \\
157.3\end{array}$ & $\begin{array}{r}19.8 \\
161.8\end{array}$ & $\begin{array}{r}20.1 \\
165.7\end{array}$ \\
\hline Total Llabilities \& Stockholders' Equity .... & 437.8 & 434.5 & 457.2 & 447.1 & 453.6 & 451.3 & 457.4 \\
\hline \multirow{3}{*}{$\begin{array}{l}\text { Memo: } \\
\text { Foreign Currency Translation Adjustment } \\
\text { Cumulative at Year End .................................. } \\
\text { Foreign Currency Translation Adjustment } \\
\text { for the Current Year ............................................. }\end{array}$} & & & & & & & \\
\hline & -4.7 & -4.3 & -3.3 & -3.2 & -6.6 & -7.3 & 0.7 \\
\hline & -0.5 & -0.5 & 1.9 & 0.1 & -3.3 & -0.6 & 1.9 \\
\hline
\end{tabular}

Source: Energy Information Administration, Form ElA-28. 
Table B10. Distribution of Net Investment in Place for FRS Companies, United States and Foreign, 1994

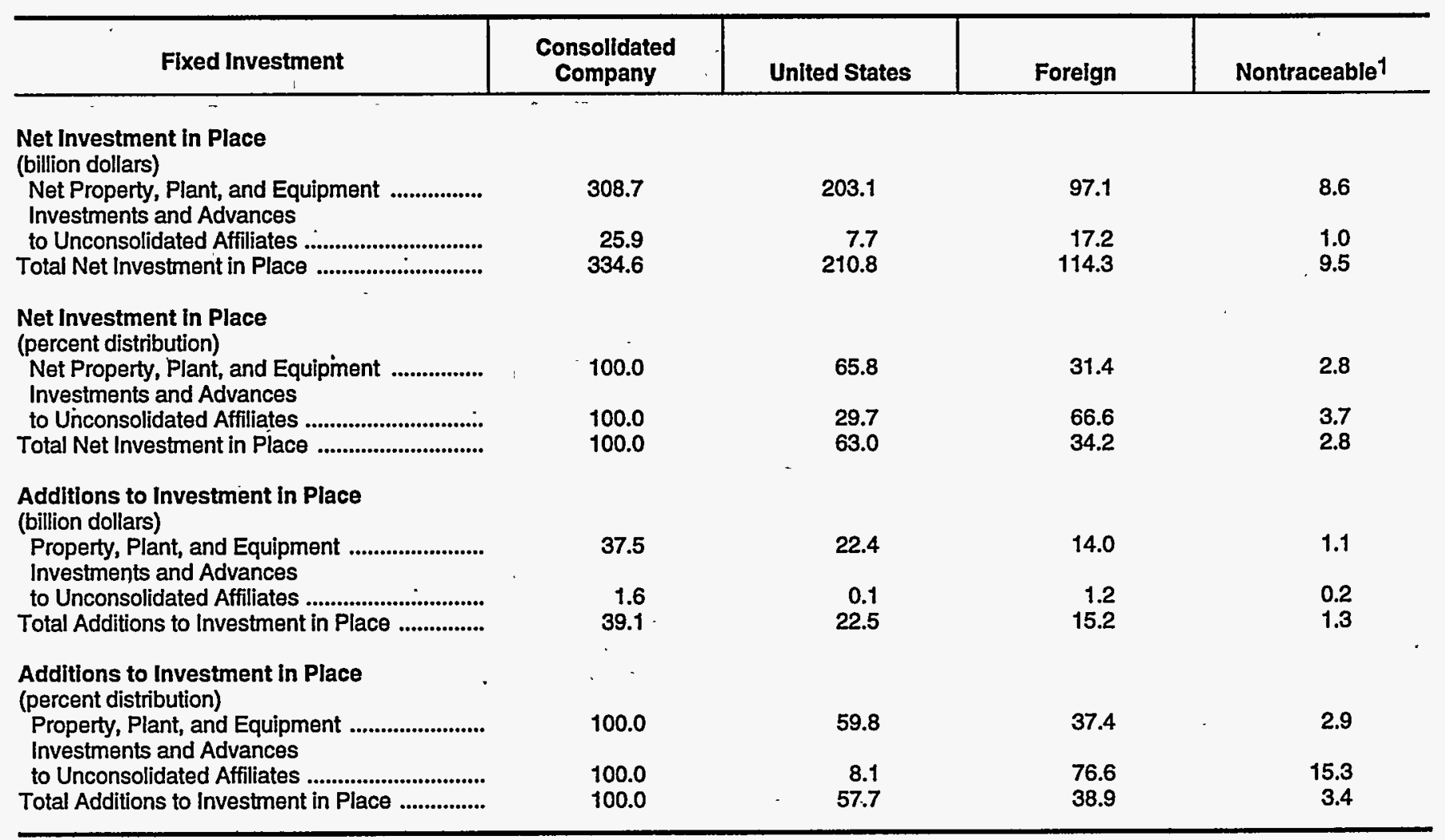

1 Includes items in consolidated balance sheet that cannot be allocated to segments (nontraceables). In this table, this column is derived as a residual.

Source: Energy Information Administration, Form EIA-28. 
Table B11. Net Property, Plant and Equipment (PP\&E), Additions to PP\&E, Investments and Advances, and Depreciation, Depletion and Amortization (DD\&A), by Lines of Business for FRS Companies, 1994

(Million Dollars)

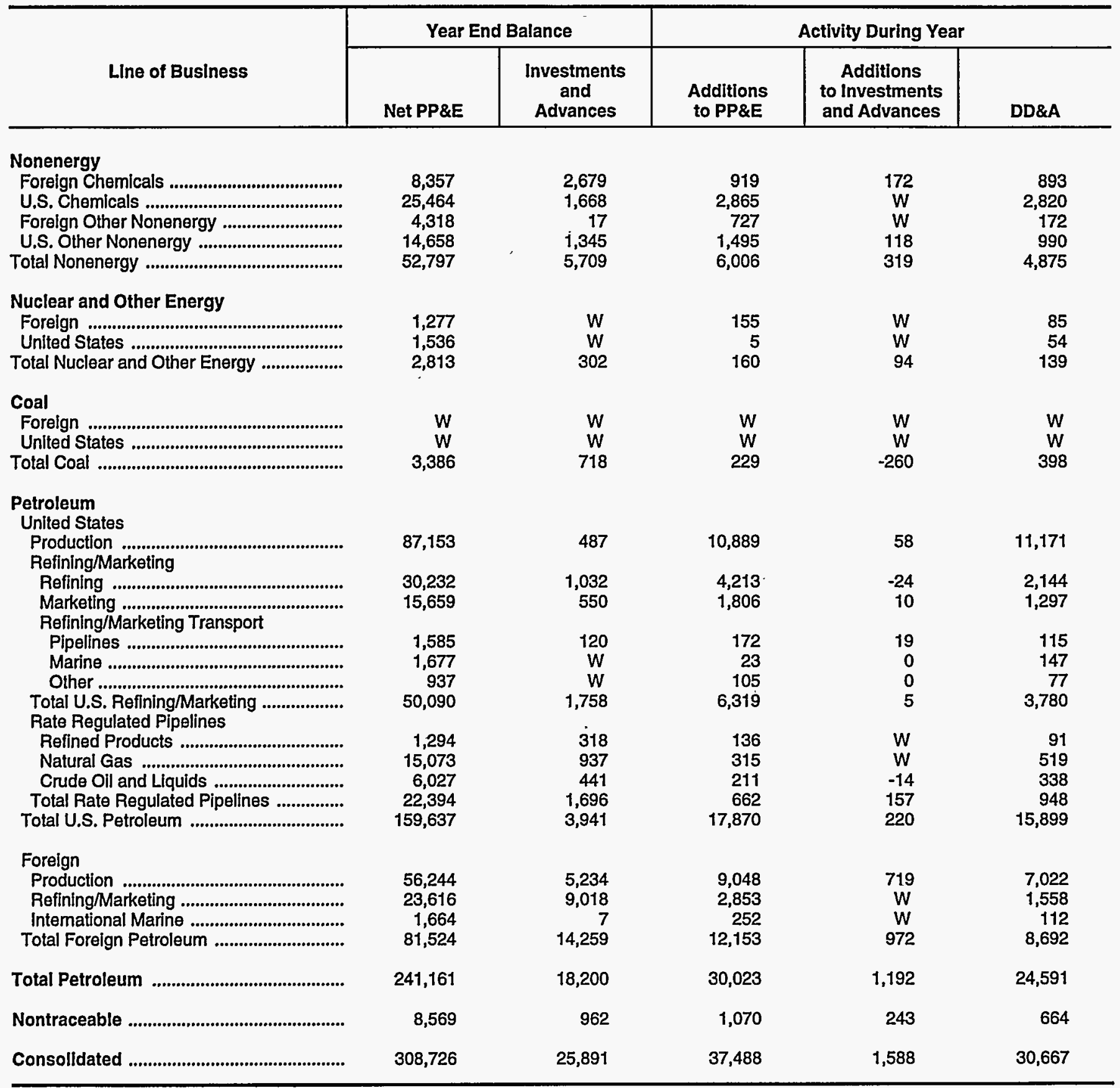

$W=$ Data withheld to avoid disclosure.

Source: Energy Information Administration, Form EIA-28. 
Table-B12. Income and Investment Patterns in Worldwide Petroleum for FRS Companies Ranked by Total Energy Assets, 1994, and Percent Change from 1993

\begin{tabular}{|c|c|c|c|}
\hline Income and Investment & Worldwide & United States & Forelgn \\
\hline - & & (million dollars) & . \\
\hline 1994 & $s$ & & \\
\hline \multicolumn{4}{|l|}{ Contribution to Net Income } \\
\hline Top Four & $7,705.0$ & $2,599.0$ & $5,106.0$ \\
\hline Five Through Twelve & $4,838.0$ & $4,156.0$ & 682.0 \\
\hline All Other & $1,854.0$ & $1,703.0$ & 151.0 \\
\hline \multicolumn{4}{|l|}{ Net Investment in Place ${ }^{1}$} \\
\hline Top Four & $117,813.0^{-}$ & $51,723.0$ & $66,090.0$ \\
\hline 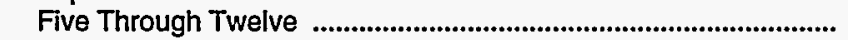 & $96,278.0$ & $76,026.0$ & $20,252.0$ \\
\hline All Other & $45,270.0$ & $35,829.0$ & $9,441.0$ \\
\hline \multicolumn{4}{|l|}{ Additions to Investment in Place } \\
\hline Top Four & $12,983.0$ & $4,835.0$ & $8,148.0$ \\
\hline 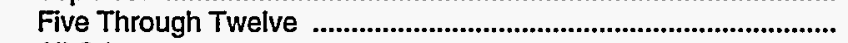 & $10,891.0$ & $7,333.0$ & $3,558.0$ \\
\hline \multirow{2}{*}{ 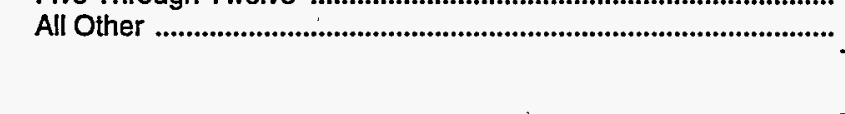 } & $7,341.0$ & $5,922.0$ & $1,419.0$ \\
\hline & \multicolumn{3}{|c|}{ (percent) } \\
\hline \multirow{2}{*}{\multicolumn{4}{|c|}{$\begin{array}{l}\text { Distribution, } 1994 \\
\text { Contribution to Net Income }\end{array}$}} \\
\hline & & & \\
\hline Top Four & 100.0 & 33.7 & 66.3 \\
\hline Five Through Twelve & 100.0 & 85.9 & 14.1 \\
\hline \multirow{2}{*}{\multicolumn{4}{|c|}{ Net Investment in Place 1}} \\
\hline & & & \\
\hline Top Four & 100.0 & 43.9 & 56.1 \\
\hline 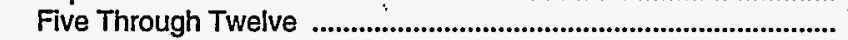 & 100.0 & 79.0 & 21.0 \\
\hline All Other & 100.0 & 79.1 & 20.9 \\
\hline \multicolumn{4}{|l|}{ Additions to Investment in Place } \\
\hline Top Four & 100.0 & 37.2 & 62.8 \\
\hline 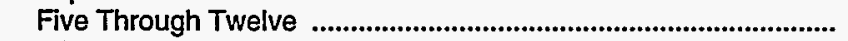 & 100.0 & 67.3 & 32.7 \\
\hline 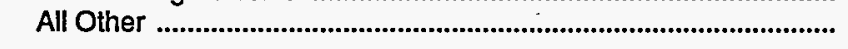 & $100: 0$ & 80.7 & 19.3 \\
\hline \multicolumn{4}{|l|}{ Change from 1993} \\
\hline Contribution to Net Income & $\therefore$ & & \\
\hline Top Four & -17.7 & 7.2 & -26.4 \\
\hline 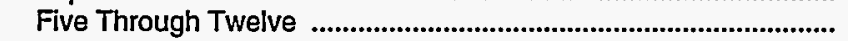 & 1.1 & 3.7 & -12.6 \\
\hline All Other & -19.9 & 2.7 & -77.0 \\
\hline \multicolumn{4}{|l|}{ Net Investment in Place 1} \\
\hline Top Four & 2.3 & -3.2 & 7.0 \\
\hline Five Through Twelve & -0.5 & -1.2 & 2.5 \\
\hline 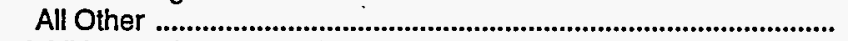 & 0.3 & 1.8 & -4.8 \\
\hline \multicolumn{4}{|l|}{ Additions to Investment in Place } \\
\hline Top Four & -6.6 & -6.6 & -6.7 \\
\hline Five Through Twelve & -6.7 & 3.1 & -21.9 \\
\hline All Other & 12.8 & 22.3 & -14.9 \\
\hline
\end{tabular}

1 Measured as net property, plant, and equipment plus investments and advances.

Note: Sum of components may not equal total due to independent rounding, eliminations, and nontraceables.

Source: Energy Information Administration, Form EIA-28. 
Table B13. Income and Investment Patterns by Petroleum Segments for FRS Companies Ranked by Total Energy Assets, 1994, and Percent Change from 1993

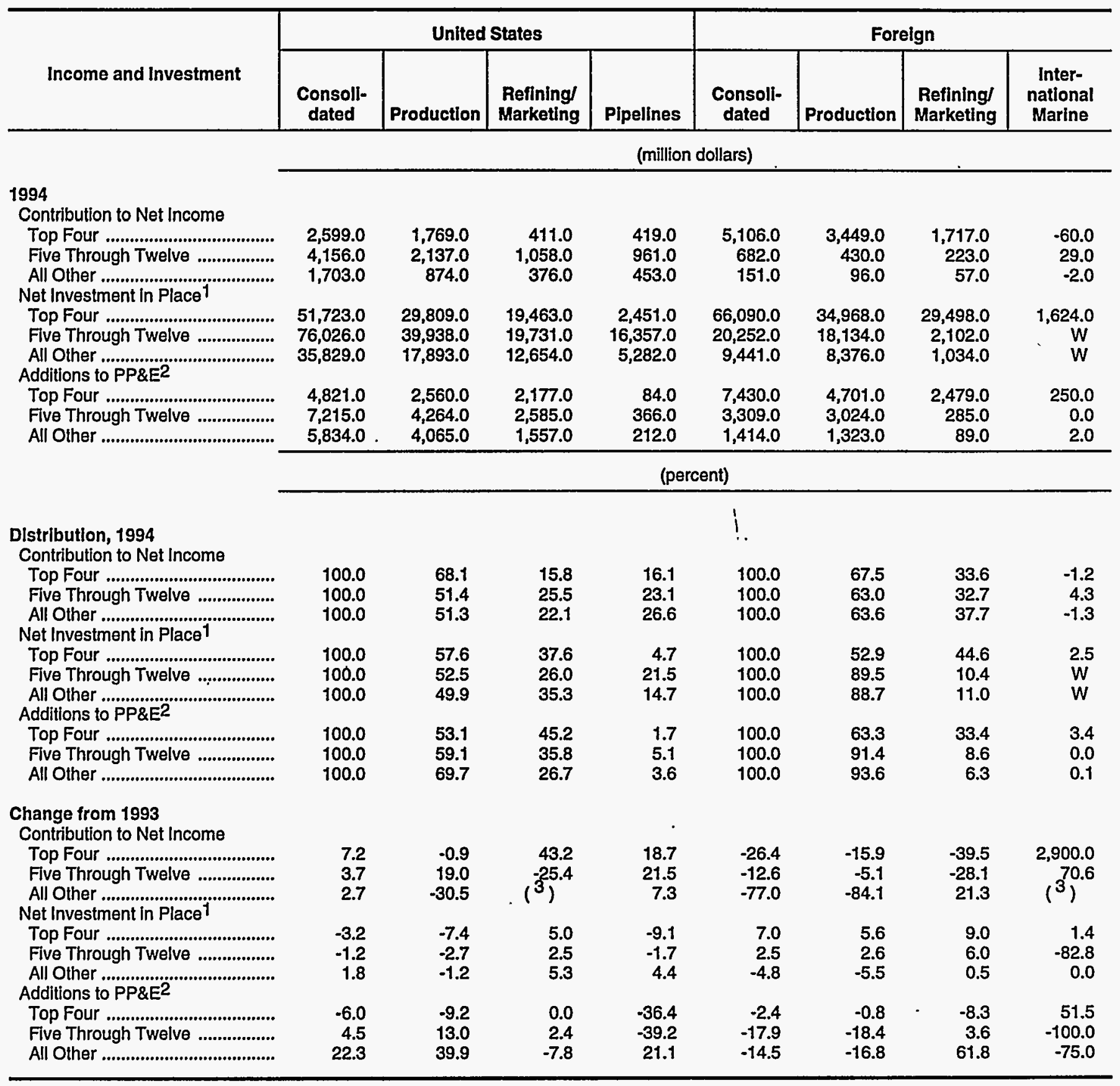

1 Measured as net property, plant, and equipment plus investments and advances.

2 Property, plant, and equipment.

3 Not meaningful.

$W=$ Data withheld to avoid disclosure.

Note: Sum of components may not equal total due to independent rounding, eliminations, and nontraceables.

Source: Energy Information Administration, Form EIA-28. 
Table B14. Size Distribution of Income and Investment Within Worldwide Petroleum for FRS Companies Ranked by Total Energy Assets, 1992-1994

(Percent)

\begin{tabular}{|c|c|c|c|c|c|c|c|c|c|}
\hline \multirow{2}{*}{$\begin{array}{l}\text { Patterns Across } \\
\text { Size Groups }\end{array}$} & \multicolumn{3}{|c|}{ Worldwide } & \multicolumn{3}{|c|}{ United States } & \multicolumn{3}{|c|}{ Forelgn } \\
\hline & 1992 & 1993 & 1994 & 1992 & 1993 & 1994 & 1992 & 1993 & 1994 \\
\hline \multicolumn{10}{|l|}{ Contribution to Net Income } \\
\hline All FRS & 100.0 & 100.0 & 100.0 & 100.0 & 100.0 & 100.0 & 100.0 & 100.0 & 100.0 \\
\hline Top Four & 64.8 & 56.9 & 53.5 & 40.1 & 30.0 & 30.7 & 91.6 & 82.8 & 86.0 \\
\hline Five Through Twelve .................................... & 27.4 & 29.1 & 33.6 & 48.0 & 49.5 & 49.1 & 5.0 & 9.3 & 11.5 \\
\hline All Other & 7.8 & 14.1 & 12.9 & 11.9 & 20.5 & 20.1 & 3.4 & 7.8 & 2.5 \\
\hline \multicolumn{10}{|l|}{ Net Investment in Place 1} \\
\hline 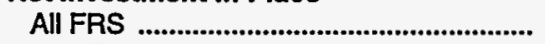 & 100.0 & 100.0 & 100.0 & 100.0 & 100.0 & 100.0 & 100.0 & 100.0 & 100.0 \\
\hline Top Four & 44.6 & 44.8 & 45.4 & 32.8 & 32.3 & 31.6 & 67.5 & 67.6 & 69.0 \\
\hline 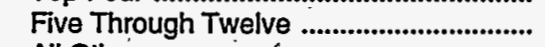 & 37.9 & 37.6 & 37.1 & 46.4 & 46.5 & 46.5 & 21.4 & 21.6 & 21.1 \\
\hline All Other & 17.5 & 17.6 & 17.5 & 20.8 & 21.3 & 21.9 & 11.1 & 10.8 & 9.9 \\
\hline \multicolumn{10}{|l|}{ Additions to Investment in Place } \\
\hline All FRS & 100.0 & & 100.0 & 100.0 & 100.0 & 100.0 & 100.0 & 100.0 & 100.0 \\
\hline Top Four & 44.9 & 43.3 & 41.6 & 32.4 & 30.2 & 26.7 & 57.2 & 58.4 & 62.1 \\
\hline Five Through Twelve ................................. & 34.1 & 36.4 & 34.9 & 40.3 & 41.5 & 40.5 & 27.8 & 30.5 & 27.1 \\
\hline All Other & 21.1 & 20.3 & 23.5 & 27.3 & 28.3 & 32.7 & 13.4 & 11.2 & 10.8 \\
\hline
\end{tabular}

1 Measured as net property, plant, and equipment plus investments and advances. Source: Energy Information Administration, Form EIA-28. 
Table B15. Consolidated Statement of Cash Flows for FRS Companies, 1988-1994

(Million Dollars)

\begin{tabular}{|c|c|c|c|c|c|c|c|}
\hline Cash Flows 1 & 1988 & 1989 & 1990 & 1991 & 1992 & 1993 & 1994 \\
\hline \multicolumn{8}{|l|}{ Cash Flows From Operatlons } \\
\hline Net Income & 22,339 & 19,784 & 21,608 & 14,679 & 1,757 & 15,488 & 16.547 \\
\hline Minority Interest in Income & 585 & 424 & 408 & 235 & 344 & 397 & 513 \\
\hline \multicolumn{8}{|l|}{ Noncash Items } \\
\hline DD\&A ................. & 31,052 & 29,598 & 30,739 & 30,017 & $31,033^{*}$ & 30,355 & 30,667 \\
\hline Dry Hole Expense, This Year ..................................... & 2,764 & 2,258 & 2,796 & 2,841 & 1,986 & $\begin{array}{r}0,073 \\
1,673\end{array}$ & $\begin{array}{r}1,805 \\
1,005\end{array}$ \\
\hline 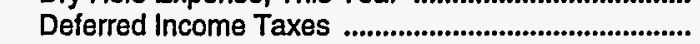 & 1,279 & 189 & -39 & $-2,062$ & $-3,929$ & -990 & 509 \\
\hline \multicolumn{8}{|l|}{ Recognized Undistributed (Earnings)/Losses } \\
\hline 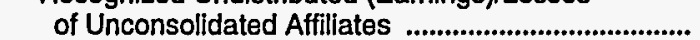 & -338 & -794 & -777 & -829 & -350 & -137 & -372 \\
\hline (Gain)/Loss on Disposition of PP\&E & $-2,064$ & $-3,335$ & -795 & $-1,808$ & $-1,294$ & -941 & -570 \\
\hline \multicolumn{8}{|l|}{ Changes in Operating Assets and Liabilities } \\
\hline 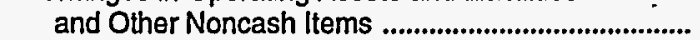 & $-4,741$ & 809 & 2,883 & 2,744 & 15,442 & 2,791 & 527 \\
\hline Other Cash Items, Net & $-2,449$ & -649 & $-1,930$ & 2,002 & -231 & 1,560 & $-1,327$ \\
\hline Net Cash Flow From Operations .................................... & 48,427 & 48,284 & 54,893 & 47,819 & 44,758 & 50,196 & 48,299 \\
\hline \multicolumn{8}{|l|}{ Cash Flows From Investing Activities } \\
\hline 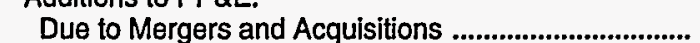 & $-15,144$ & $-8,676$ & $-3,467$ & $-1,075$ & -874 & -306 & $-2,271$ \\
\hline Other & $-34,653$ & $-34,847$ & $-41,122$ & $-43,812$ & $-39,604$ & $-37,755$ & $-35,217$ \\
\hline Total Additions to PP\&E & $-49,797$ & $-43,523$ & $-44,589$ & $-44,887$ & $-40,478$ & $-38,061$ & $-37,488$ \\
\hline Additions to Investments and Advances ...................... & 121 & $-1,468$ & -886 & $-1,520$ & $-1,483$ & $-2,318$ & $-1,588$ \\
\hline Proceeds From Disposals of PP\&E & 15,960 & 13,404 & 7,143 & 9,359 & 7,268 & 11,757 & 6,447 \\
\hline 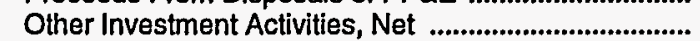 & 4,623 & $-2,209$ & 327 & -103 & $-1,584$ & $-2,242$ & $-2,363$ \\
\hline 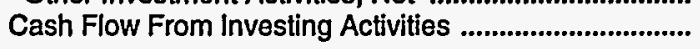 & $-29,093$ & $-33,796$ & $-38,005$ & $-37,151$ & $-36,277$ & $-30,864$ & $-34,992$ \\
\hline \multicolumn{8}{|l|}{ Cash Flows From Financing Activities } \\
\hline 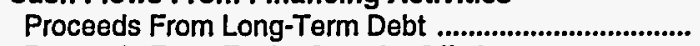 & 19,313 & 20,668 & 15,759 & 22,120 & 24,745 & 18,982 & 12,500 \\
\hline Proceeds From Equity Security Offerings ..................... & 2,709 & 4,248 & 1,501 & 491 & 3,438 & 2,146 & 2,614 \\
\hline 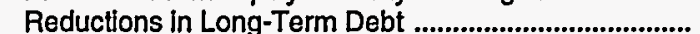 & $-28,775$ & $-19,820$ & $-17,223$ & $-18,411$ & $-25,284$ & $-20,886$ & $-13,760$ \\
\hline Purchase of Treasury Stock & $-6,637$ & $-6,190$ & $-5,435$ & $-1,973$ & -824 & -514 & $-1,010$ \\
\hline \multirow{2}{*}{\multicolumn{8}{|c|}{ Other Financing Activities, Including Net Change }} \\
\hline & & & & & & & \\
\hline 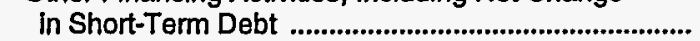 & 413 & 2,111 & 243 & -978 & 2,308 & $-4,102$ & $-1,091$ \\
\hline Cash Flow From Financing Activities ............................. & $-25,420$ & $-15,682$ & $-18,455$ & $-12,248$ & $-9,138$ & $-17,937$ & $-15,653$ \\
\hline 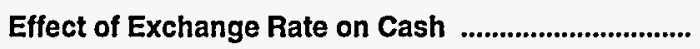 & -247 & -286 & 74 & -138 & -359 & -198 & 131 \\
\hline \multicolumn{8}{|l|}{ Net Increase/(Decrease) in Cash and Cash } \\
\hline Equivalents & $-6,333$ & $-1,480$ & $-1,493$ & $-1,718$ & $-1,016$ & 1,197 & $-2,215$ \\
\hline
\end{tabular}

1 Items that add to cash are positive, and items that use cash are shown as negative values.

Source: Energy Information Administration, Form EIA-28. 
Table B16. A Comparison of Key Financial Indicators, Selected Performance Measures, and Patterns of Finance for FRS Companies and for the S\&P 400, 1992-1994

(Percent)

\begin{tabular}{|c|c|c|c|c|c|c|}
\hline \multirow{2}{*}{ Financial Indicators } & \multicolumn{3}{|c|}{ FRS Companies } & \multicolumn{3}{|c|}{ S\&P 400} \\
\hline & 1992 & 1993 & 1994 & 1992 & 1993 & 1994 \\
\hline \multicolumn{7}{|l|}{ Profitability Measures } \\
\hline 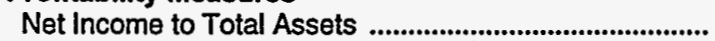 & 0.4 & 3.4 & 3.6 & 0.7 & 2.6 & 4.8 \\
\hline Net Income to Stockholders' Equity & 1.1 & 9.6 & 10.0 & 2.5 & 9.4 & 16.4 \\
\hline Net Income Plus Interest to Total Invested Capital ......... & 4.3 & 9.3 & 9.7 & 6.7 & 10.3 & 14.1 \\
\hline \multicolumn{7}{|l|}{ Cash Flow from Operations and Uses of Cash } \\
\hline Net Cash Flow from Operations to Total Assets ............ & 9.9 & 11.1 & 10.6 & 8.8 & 8.9 & 9.2 \\
\hline Additions to PP\&E to Net Cash Flow from Operations ... & 90.4 & 75.8 & 77.6 & 67.6 & 63.3 & 65.2 \\
\hline Dividends to Net Cash Flow from Operations .................. & 30.2 & 27.0 & 30.9 & 23.8 & 22.7 & 21.2 \\
\hline \multicolumn{7}{|l|}{ Liquidity and Leverage Measures } \\
\hline Long-Term Debt to Stockholders' Equity .......................... & 59.4 & 55.2 & 53.1 & 70.0 & 69.1 & 65.6 \\
\hline 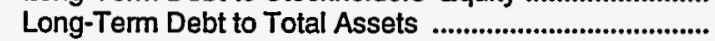 & 20.6 & 19.8 & 19.3 & 20.3 & 19.1 & 19.2 \\
\hline 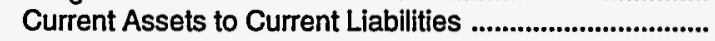 & 96.1 & 97.3 & 99.2 & 105.3 & 100.4 & 116.3 \\
\hline
\end{tabular}

Sources: Standard \& Poor's (S\&P) 400 data - Compustat, Inc. FRS companies' data - Energy Information Administration, Form EIA-28. 
Table B17. Worldwide Income Taxes for FRS Companies, 1993 and 1994

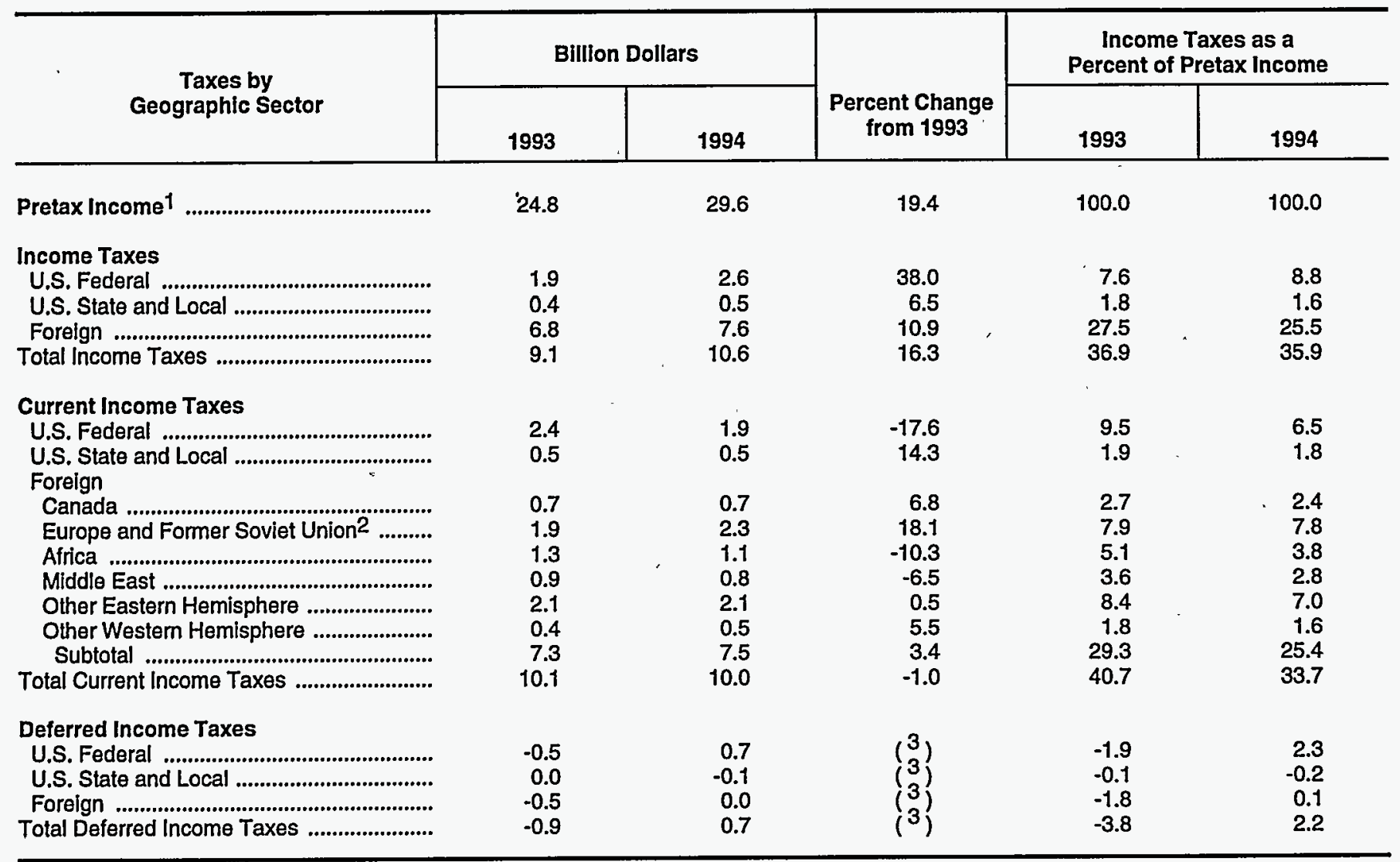

1 Excludes discontinued operations, extraordinary items, and cumulative effect of accounting changes.

2 OECD Europe combined with the former Soviet Union and Eastern Europe to avoid disclosure. Prior to 1993, only OECD Europe is Included in this region.

3 Not meaningful.

Source: Energy Information Administration, Form ElA-28. 
Table B18. U.S. Federal Income Taxes for FRS Companies, 1993 and 1994

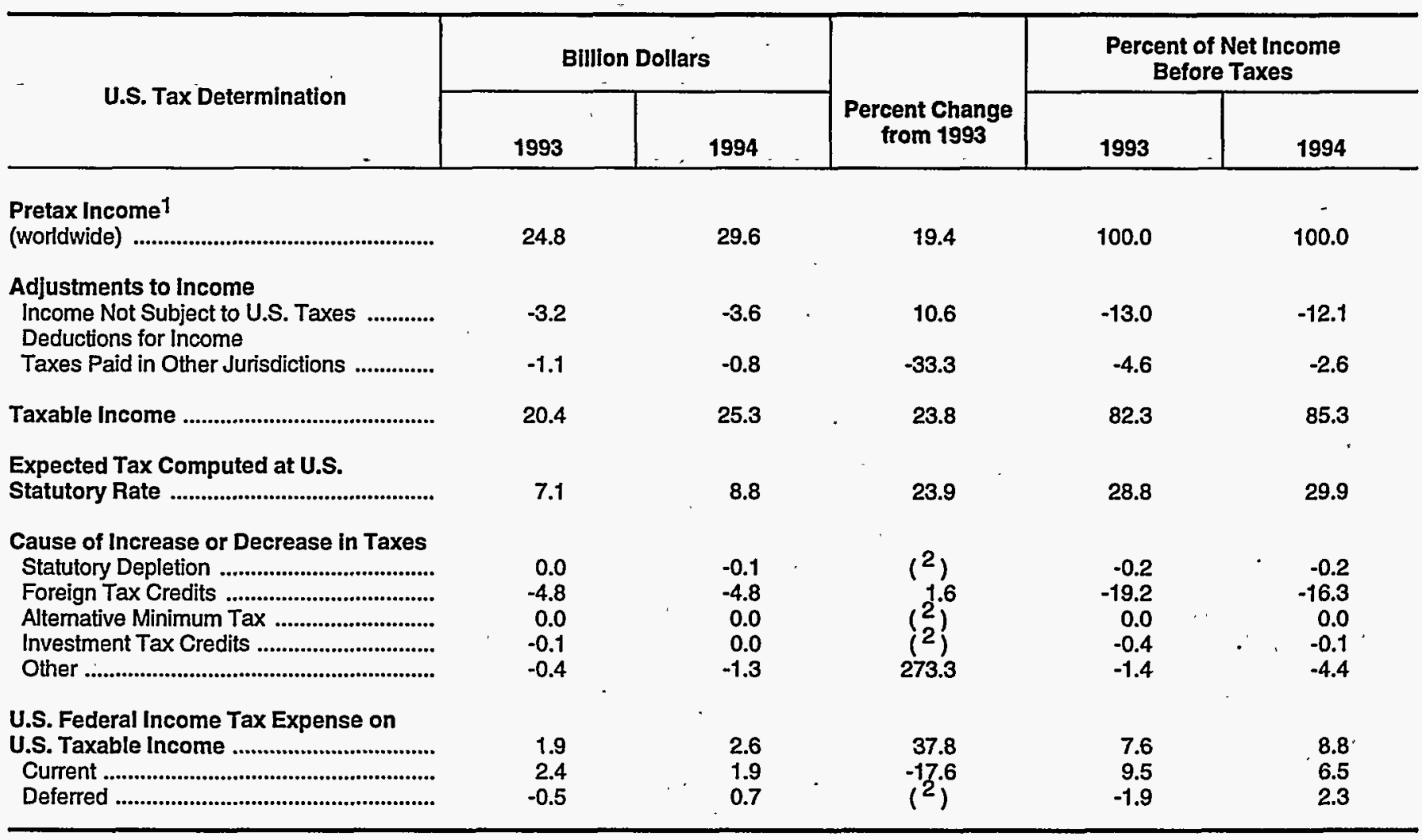

1 Excludes discontinued operations, extraordinary items, and cumulative effect of accounting changes.

2 Not meaningful.

Source: Energy Information Administration, Form EIA-28. 
Table B19. Analysis of Income Taxes for FRS Companies, 1988-1994

(Million Dollars)

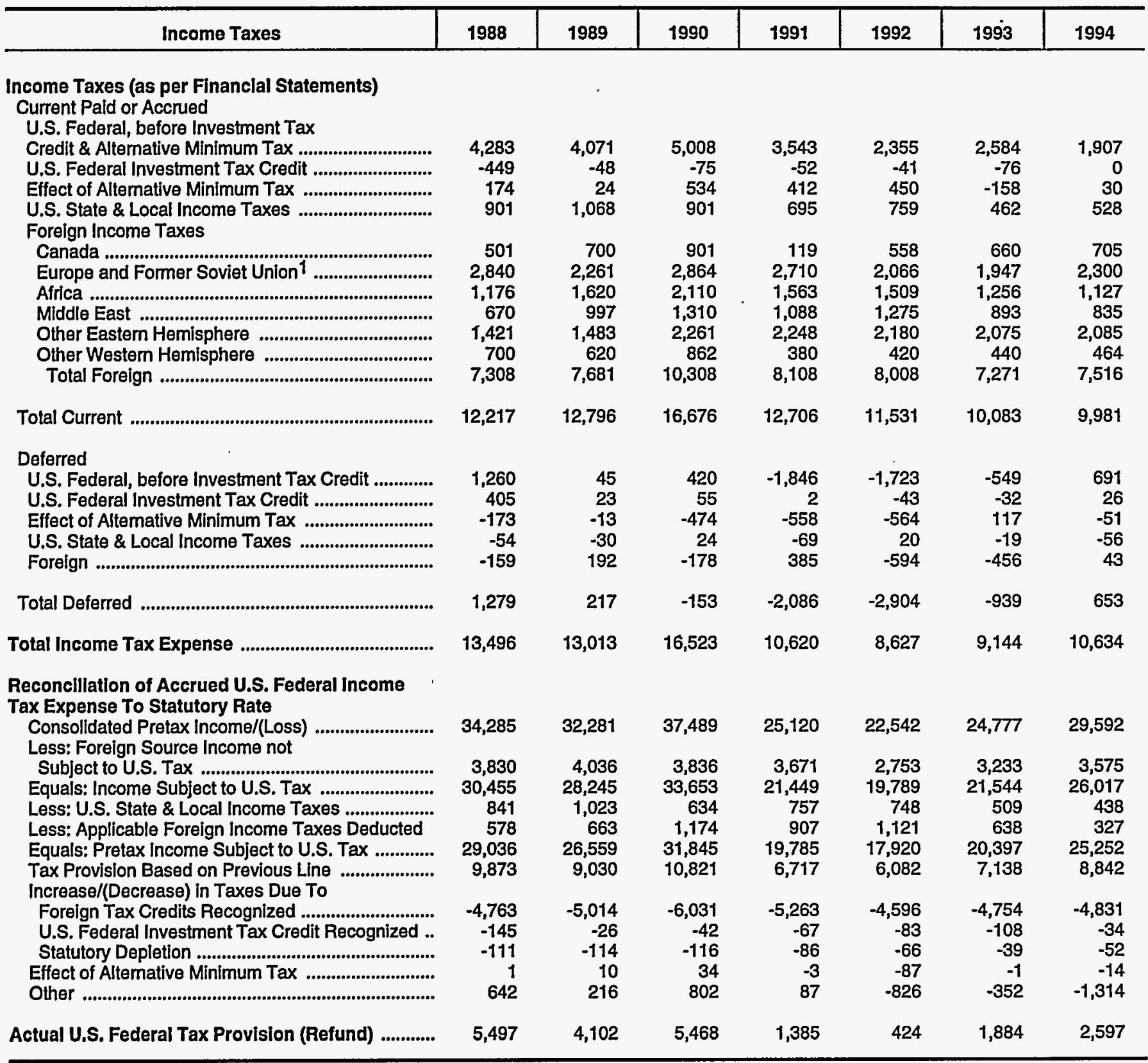

1 OECD Europe combined with the former Soviet Union and.Eastern Europe to avoid disclosure. Prior to 1993, only OECD Europe is Included in this region.

Source: Energy Information Administration, Form EIA-28. 
Table B20. U.S. Taxes Other Than Income Taxes for FRS Companies, 1994, and Percent Change from 1993

\begin{tabular}{|c|c|c|c|c|c|c|c|c|}
\hline \multirow[b]{2}{*}{$\begin{array}{l}\text { U.S. Taxes Other } \\
\text { than Income Taxes }\end{array}$} & \multicolumn{2}{|c|}{ Total United States } & \multicolumn{2}{|c|}{ Petroleum } & \multicolumn{2}{|c|}{ Coal } & \multicolumn{2}{|c|}{ Other 1} \\
\hline & $\begin{array}{l}1994 \\
\text { (million } \\
\text { dollars) }\end{array}$ & $\begin{array}{c}\text { Percent } \\
\text { Change } \\
\text { from 1993 }\end{array}$ & $\begin{array}{l}1994 \\
\text { (million } \\
\text { dollars) }\end{array}$ & $\begin{array}{c}\text { Percent } \\
\text { Change } \\
\text { from } 1993\end{array}$ & $\begin{array}{c}1994 \\
\text { (million } \\
\text { dollars) }\end{array}$ & $\begin{array}{c}\text { Percent } \\
\text { Change } \\
\text { from } 1993\end{array}$ & $\begin{array}{c}1994 \\
\text { (million } \\
\text { dollars) }\end{array}$ & $\begin{array}{c}\text { Percent } \\
\text { Change } \\
\text { from } 1993\end{array}$ \\
\hline \multirow{2}{*}{\multicolumn{9}{|c|}{$\begin{array}{l}\text { Production Taxes } \\
\text { Windfall Profit Tax }\end{array}$}} \\
\hline & 0.0 & -100.0 & 0.0 & -100.0 & 0.0 & -- & 0.0 & - \\
\hline Severance Taxes & $1,678.0$ & -9.4 & $1,619.0$ & -7.6 & W & W & w & W \\
\hline Other Direct Production Taxes ............................ & 172.0 & -25.5 & 100.0 & -28.1 & $w$ & W & W & W \\
\hline 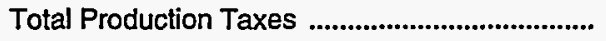 & $1,850.0$ & -11.8 & $1,719.0$ & -9.8 & 126.0 & -32.6 & 5.0 & 0.0 \\
\hline 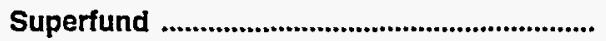 & 291.0 & -9.1 & 249.0 & -11.1 & 0.0 & -- & 42.0 & 5.0 \\
\hline 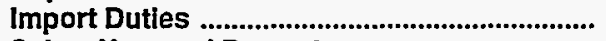 & 122.0 & -3.9 & - & - & - & - & - & - \\
\hline Sales, Use, and Property & $3,089.0$ & -0.5 & - & - & - & - & _- & - \\
\hline Payroll & $1,986.0$ & -6.9 & - & - & - & - & - & - \\
\hline Other Taxes & 630.0 & -1.3 & - & - & - & - & - & - \\
\hline \multicolumn{9}{|l|}{ Total Taxes Paid (Other Than Income } \\
\hline Taxes) & $7,968.0$ & -5.4 & - & - & - & - & - & - \\
\hline 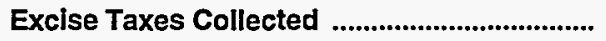 & $30,092.0$ & 18.9 & - & - & - & - & - & - \\
\hline
\end{tabular}

1 Nuclear, Other Energy, and Nonenergy.

$\bar{W}=$ Not available.

$W=$ Data withheld to avoid disclosure.

- = Not applicable.

Source: Energy Information Administration, Form EIA-28. 
Table B21. Petroleum Exploration and Development Expenditures for FRS Companies, United States and Foreign, 1994, and Percent Change from 1993

\begin{tabular}{|c|c|c|c|c|c|c|c|}
\hline \multirow[b]{2}{*}{$\begin{array}{c}\text { Exploration } \\
\text { and } \\
\text { Development } \\
\text { Expenditures }\end{array}$} & \multirow{2}{*}{\begin{tabular}{|c|}
$\begin{array}{c}\text { Worldwide } \\
\text { Expenditures }\end{array}$ \\
$\begin{array}{c}\text { FRS } \\
\text { Companies } \\
\text { (million } \\
\text { dollars) } \\
1994\end{array}$
\end{tabular}} & \multicolumn{3}{|c|}{ U.S. Expenditures · } & \multicolumn{3}{|c|}{ Foreign Expenditures } \\
\hline & & $\begin{array}{c}\text { FRS } \\
\text { Companies } \\
\text { (million } \\
\text { dollars) } \\
1994\end{array}$ & $\begin{array}{c}\text { Percent } \\
\text { Change } \\
\text { from } 1993\end{array}$ & $\begin{array}{c}\text { U.S. FRS } \\
\text { as a Percent } \\
\text { of Total FRS } \\
1994\end{array}$ & $\begin{array}{c}\text { FRS } \\
\text { Companies } \\
\text { (million } \\
\text { dollars) } \\
1994\end{array}$ & $\begin{array}{c}\text { Percent } \\
\text { Change } \\
\text { from } 1993\end{array}$ & $\begin{array}{c}\text { FRS Foreign } \\
\text { as a Percent } \\
\text { of Total FRS } \\
1994\end{array}$ \\
\hline \multicolumn{8}{|l|}{ Exploration } \\
\hline Acquisition of Unproved Acreage ........ & 820.0 & 477.0 & 34.4 & 58.2 & 343.0 & 17.9 & 41.8 \\
\hline Geological and Geophysical .................. & $1,337.0$ & 405.0 & -1.0 & 30.3 & 932.0 & 14.6 & 69.7 \\
\hline 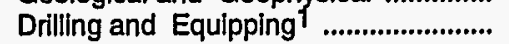 & $3,482.0$ & $1,887.0$ & 37.7 & 54.2 & $1,595.0$ & 2.0 & 45.8 \\
\hline Other & $1,579.0$ & 619.0 & -5.1 & 39.2 & 960.0 & -5.0 & 60.8 \\
\hline 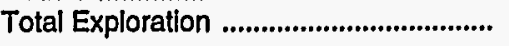 & $7,218.0$ & $3,388.0$ & 21.6 & 46.9 & $3,830.0$ & 4.1 & 53.1 \\
\hline \multicolumn{8}{|l|}{ Development } \\
\hline Acquisition of Proved Acreage ............. & $2,313.0$ & $1,576.0$ & 163.1 & 68.1 & 737.0 & 81.1 & 31.9 \\
\hline 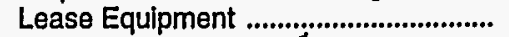 & $2,715.0$ & $1,386.0$ & -15.5 & 51.0 & $1,329.0$ & -46.3 & 49.0 \\
\hline 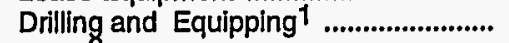 & $8,609.0$ & $4,524.0$ & 12.8 & 52.5 & $4,085.0$ & -0.8 & 47.5 \\
\hline 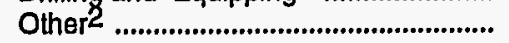 & $3,642.0$ & $1,714.0$ & -9.6 & 47.1 & $1,928.0$ & 3.3 & 52.9 \\
\hline 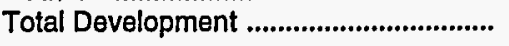 & $17,279.0$ & $9,200.0$ & 12.9 & 53.2 & $8,079.0$ & -8.9 & 46.8 \\
\hline Total Exploration and Development .. & $24,497.0$ & $12,588.0$ & 15.1 & 51.4 & $11,909.0$ & -5.1 & 48.6 \\
\hline
\end{tabular}

1 Expenditure incurred in a given year not cumulative (includes work in progress adjustment).

2 Includes support equipment.

Source: Energy Information Administration, Form EIA-28. 
Table B22. U.S. and Foreign Exploration and Development Expenditures and Production (Lifting) Costs for FRS Companies, 1994

(Million Dollars)

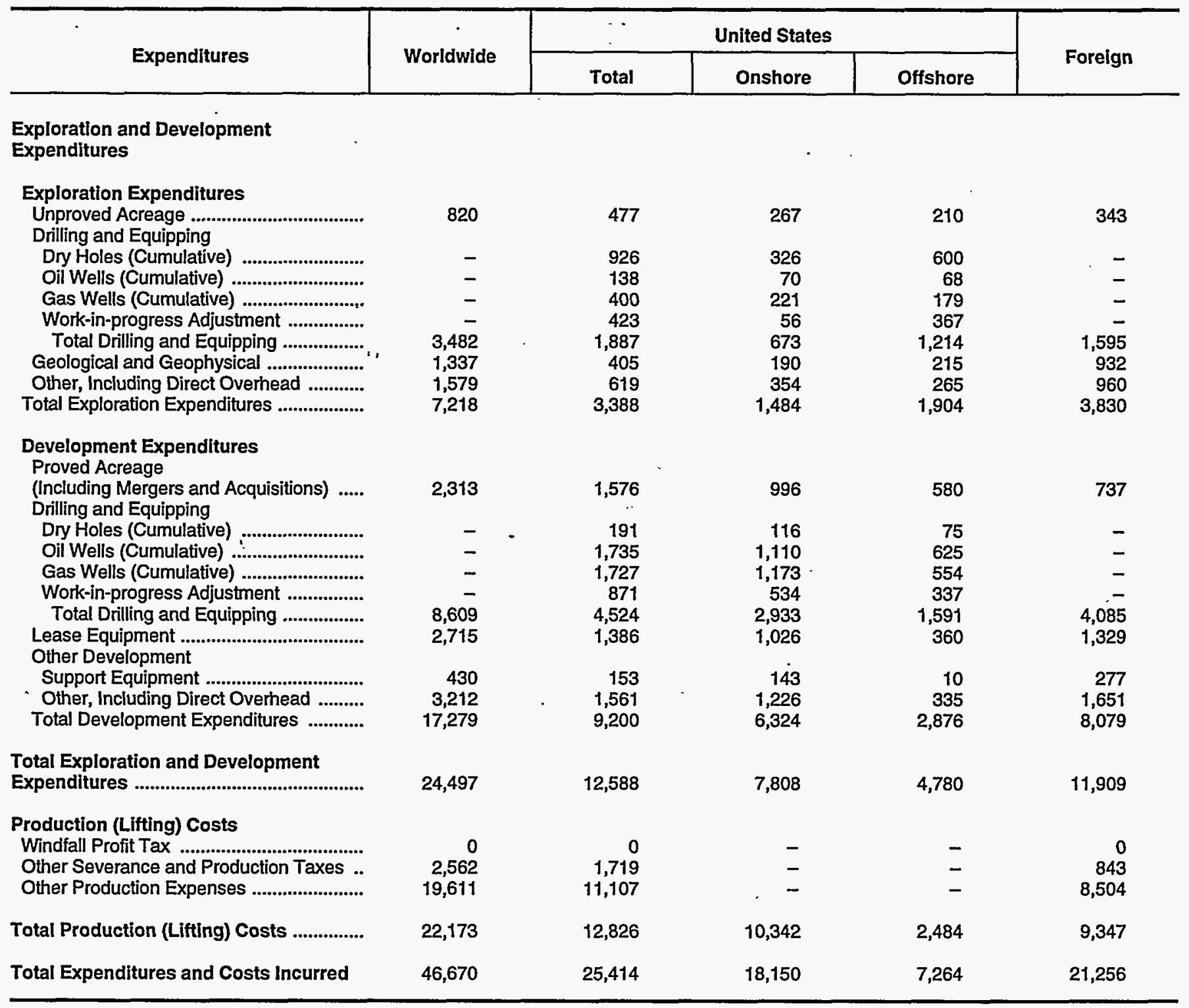

- = Not available.

Source: Energy Information Administration, Form ElA-28. 
Table B23. Total Exploratory and Development Wells Drilled in the United States for FRS Companies and U.S. Industry, 1993 and 1994

\begin{tabular}{|c|c|c|c|c|c|c|}
\hline \multirow{2}{*}{ Wells Drilled } & \multicolumn{2}{|c|}{ U.S. Industry } & \multicolumn{2}{|c|}{ FRS } & \multicolumn{2}{|c|}{ All Other } \\
\hline & 1993 & 1994 & 1993 & 1994 & 1993 & 1994 \\
\hline 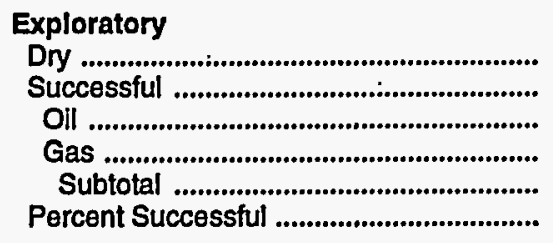 & $\begin{array}{r}2,515 \\
967 \\
479 \\
488 \\
3,482 \\
27.8\end{array}$ & $\begin{array}{r}2,271 \\
1,321 \\
603 \\
718 \\
3,592 \\
36.8\end{array}$ & $\begin{array}{l}300 \\
299 \\
130 \\
169 \\
599 \\
49.9\end{array}$ & $\begin{array}{l}253 \\
328 \\
114 \\
214 \\
581 \\
56.5\end{array}$ & $\begin{array}{r}2,215 \\
668 \\
349 \\
319 \\
2,883 \\
23.2\end{array}$ & $\begin{array}{r}2,018 \\
993 \\
489 \\
504 \\
3,011 \\
33.0\end{array}$ \\
\hline 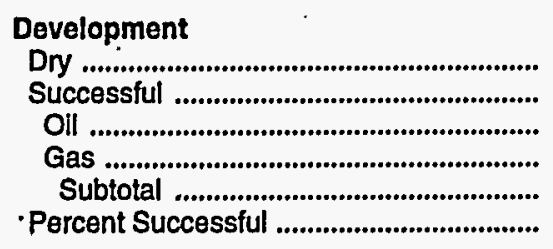 & $\begin{array}{r}4,190 \\
17,542 \\
8,248 \\
9,294 \\
21,733 \\
80.7\end{array}$ & $\begin{array}{r}3,055 \\
14,309 \\
6,160 \\
8,149 \\
17,363 \\
82.4\end{array}$ & $\begin{array}{r}249 \\
3,852 \\
2,091 \\
1,761 \\
4,101 \\
93.9\end{array}$ & $\begin{array}{r}220 \\
4,115 \\
2,130 \\
1,985 \\
4,335 \\
94.9\end{array}$ & $\begin{array}{r}3,941 \\
13,690 \\
6,157 \\
7,533 \\
17,632 \\
77.6\end{array}$ & $\begin{array}{r}2,835 \\
10,194 \\
4,030 \\
6,164 \\
13,028 \\
78.2\end{array}$ \\
\hline 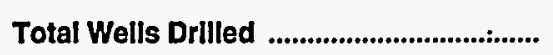 & 25,215 & 20,955 & 4,700 & 4,916 & 20,515 & 16,039 \\
\hline
\end{tabular}

Note: Sum of components may not equal total due to independent rounding.

Sources: Industry data - Special compilation provided by the Office of Oil and Gas, Energy Information Administration. Totals are based on data which appeared in the Energy Information Administration's Monthly Energy Review, August 1995, p. 83. FRS companies data Energy information Administration, Form ElA-28. 
Table B24. Completed Well Costs, Oil, Gas, and Dry, for FRS Companies and U.S. Industry, 1993 and 1994

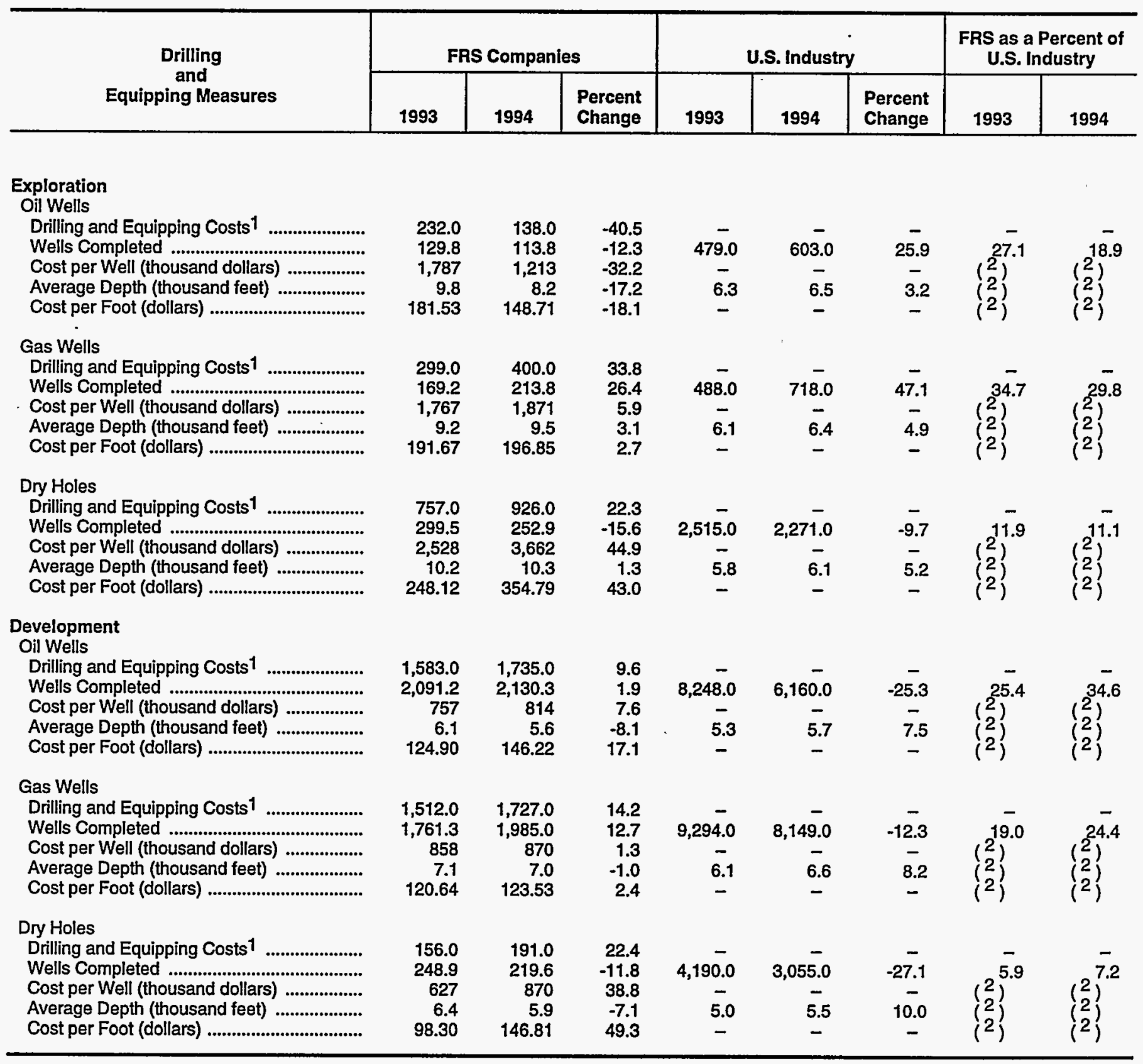

1 Million Dollars.

2 Not meaningful.

- Not available.

Sources: Industry data - Special compilation provided by the Office of Oil and Gas, Energy Information Administration. Totals are based on data which appeared in the Energy Information Administration's Monthly Energy Review, August 1995, p. 83. FRS companies data - Energy Information Administration, Form ElA-28. 
Table B25. Completed Well Costs, Oil, Gas, and Dry, Onshore and Offshore, for FRS Companies, 1993 and 1994

\begin{tabular}{|c|c|c|c|c|c|c|c|c|c|}
\hline \multirow{2}{*}{$\begin{array}{c}\text { Drilling } \\
\text { and } \\
\text { Equipping Measures }\end{array}$} & \multicolumn{3}{|c|}{ Total United States } & \multicolumn{3}{|c|}{ U.S. Onshore } & \multicolumn{3}{|c|}{ U.S. Offshore } \\
\hline & 1993 & 1994 & $\begin{array}{l}\text { Percent } \\
\text { Change }\end{array}$ & 1993 & 1994 & $\begin{array}{l}\text { Percent } \\
\text { Change }\end{array}$ & 1993 & 1994 & $\begin{array}{l}\text { Percent } \\
\text { Change }\end{array}$ \\
\hline \multicolumn{10}{|l|}{ Exploration } \\
\hline Drilling and Equipping Costs ${ }^{1}$.......... & 232.0 & 138.0 & -40.5 & 104.0 & 70.0 & -32.7 & 128.0 & 68.0 & -46.9 \\
\hline 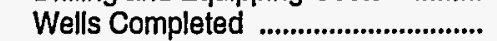 & 129.8 & 113.8 & $=-12.3$ & 107.9 & 101.2 & -6.2 & 21.9 & 12.6 & -42.5 \\
\hline Cost per Well (thousand dollars) ..... & 1,787 & 1,213 & -32.2 & 964 & 692 & -28.2 & 5,845 & 5,397 & -7.7 \\
\hline Average Depth (thousand feet) ........ & 9.8 & 8.2 & -17.2 & 9.0 & 7.9 & -12.9 & 13.9 & 10.5 & -24.5 \\
\hline Cost per Foot (dollars) .......................... & 181.53 & 148.71 & -18.1 & 106.78 & 87.94 & -17.6 & 421.05 & 515.15 & 22.3 \\
\hline \multicolumn{10}{|l|}{ Gas Wells } \\
\hline Drilling and Equipping Costs ${ }^{1}$ & 299.0 & 400.0 & 33.8 & 150.0 & 221.0 & 47.3 & 149.0 & 179.0 & 1 20.1 \\
\hline Wells Completed ................................. & 169.2 & 213.8 & 26.4 & 127.2 & 166.9 & 31.2 & 42.0 & 46.9 & 11.7 \\
\hline Cost per Well (thousand dollars) ..... & 1,767 & 1,871 & 5.9 & 1,179 & 1,324 & 12.3 & 3,548 & 3,817 & 7.6 \\
\hline Average Depth (thousand feet) ........ & 9.2 & 9.5 & 3.1 & 8.4 & 8.8 & 4.1 & 11.6 & 12.1 & 4.2 \\
\hline 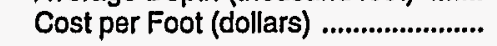 & 191.67 & 196.85 & 2.7 & 139.93 & 150.96 & 7.9 & 305.33 & 315.14 & 3.2 \\
\hline \multicolumn{10}{|l|}{ Dry Holes } \\
\hline Drilling and Equipping Costs ${ }^{1}$ & 757.0 & 926.0 & 22.3 & 316.0 & 326.0 & 3.2 & 441.0 & 600.0 & 36.1 \\
\hline Wells Completed ................................. & 299.5 & 252.9 & -15.6 & 230.6 & 174.5 & -24.3 & 68.9 & 78.4 & 13.8 \\
\hline Cost per Well (thousand dollars) ..... & 2,528 & 3,662 & 44.9 & 1,370 & 1,868 & 36.3 & 6,401 & 7,653 & 19.6 \\
\hline Average Depth (thousand feet) ........ & 10.2 & 10.3 & 1.3 & 10.2 & 9.7 & -4.1 & 10.3 & 11.6 & 12.8 \\
\hline Cost per Foot (dollars) ............................. & 248.12 & 354.79 & 43.0 & 134.99 & 191.88 & 42.1 & 621.13 & 658.62 & 6.0 \\
\hline \multirow{2}{*}{\multicolumn{10}{|c|}{$\begin{array}{l}\text { Development } \\
\text { Oll Wells }\end{array}$}} \\
\hline & & & & & & & & & \\
\hline Drilling and Equipping Costs ${ }^{1} \ldots . . . . .$. & $1,583.0$ & $1,735.0$ & 9.6 & $1,181.0$ & $1,110.0$ & -6.0 & 402.0 & 625.0 & 55.5 \\
\hline Wells Completed & $2,091.2$ & $2,130.3$ & 1.9 & $1,965.8$ & $1,980.2$ & 0.7 & 125.4 & 150.1 & 19.7 \\
\hline Cost per Well (thousand dollars) ..... & 757 & 814 & 7.6 & 601 & 561 & -6.7 & 3,206 & 4,164 & 29.9 \\
\hline Average Depth (thousand feet) ....... & 6.1 & & -8.1 & 5.8 & 5.2 & -10.6 & 10.1 & 10.6 & 5.3 \\
\hline 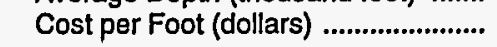 & 124.90 & 146.22 & 17.1 & 103.53 & 108.09 & 4.4 & 317.28 & 391.36 & 23.3 \\
\hline \multicolumn{10}{|l|}{ Gas Wells } \\
\hline Drilling and Equipping Costs 1 .......... & $1,512.0$ & $1,727.0$ & 14.2 & $1,039.0$ & $1,173.0$ & 12.9 & 473.0 & 554.0 & 17.1 \\
\hline 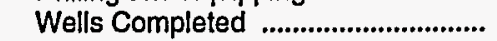 & $1,761.3$ & $1,985.0$ & 12.7 & $1,663.8$ & $1,864.9$ & 12.1 & 97.5 & 120.1 & 23.2 \\
\hline Cost per Well (thousand dollars) ...... & 858 & 870 & 1.3 & 624 & 629 & 0.7 & 4,851 & 4,613 & -4.9 \\
\hline Average Depth (thousand feet) & 7.1 & 7.0 & -1.0 & 6.9 & 6.9 & 0.0 & 10.0 & 8.5 & -14.7 \\
\hline 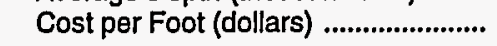 & 120.64 & 123.53 & 2.4 & 89.89 & 90.54 & 0.7 & 485.13 & 540.49 & 11.4 \\
\hline \multicolumn{10}{|l|}{ Dry Holes } \\
\hline Drilling and Equipping Costs ${ }^{1}$ & 156.0 & 191.0 & 22.4 & 106.0 & 116.0 & 9.4 & 50.0 & 75.0 & 50.0 \\
\hline Wells Completed ............................... & 248.9 & 219.6 & -11.8 & 235.8 & 202.7 & -14.0 & 13.1 & 16.9 & 29.0 \\
\hline Cost per Well (thousand dollars) ...... & 627 & 870 & 38.8 & 450 & 572 & 27.3 & 3,817 & 4,438 & 16.3 \\
\hline Average Depth (thousand feet) ........ & 6.4 & 5.9 & -7.1 & 6.1 & 5.8 & -4.2 & 12.1 & 7.3 & -39.2 \\
\hline 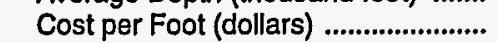 & 98.30 & 146.81 & 49.3 & 74.18 & 98.56 & 32.9 & 316.46 & 604.84 & 91.1 \\
\hline
\end{tabular}

1 Million Dollars.

Source: Energy Information Administration, Form EIA-28. 
Table B26. U.S. Net Wells Completed, and Net In-Progress Wells for FRS Companies, 1988-1994

\begin{tabular}{|c|c|c|c|c|c|c|c|}
\hline Wells & 1988 & 1989 & 1990 & 1991 & 1992 & 1993 & 1994 \\
\hline \multicolumn{8}{|l|}{$\begin{array}{l}\text { Number of Net Wells Completed } \\
\text { During Year }\end{array}$} \\
\hline \multicolumn{8}{|l|}{ Onshore } \\
\hline Net Exploratory Wells & & - & & - & & & \\
\hline 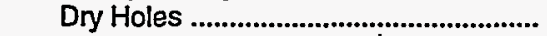 & 574 & 395 & 411 & 297 & 294 & 231 & 175 \\
\hline 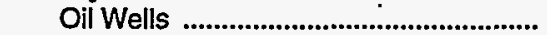 & 164 & 105 & 132 & 155 & 112 & 108 & 101 \\
\hline 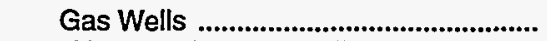 & 202 & 270 & 490 & 283 & 127 & 127 & 167 \\
\hline 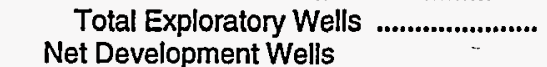 & 940 & 769 & 1,033 & 735 & 533 & 466 & 443 \\
\hline 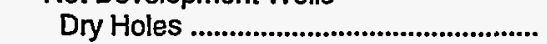 & 388 & 299 & 260 & 326 & 193 & 236 & 203 \\
\hline 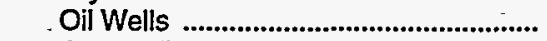 & 3,742 & 2,604 & 3,337 & 2,738 & 1,664 & 1,966 & 1,980 \\
\hline 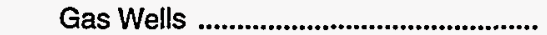 & 1,022 & 1,161 & 1,681 & 1,354 & 1,582 & 1,664 & 1,865 \\
\hline Total Development Wells ..................... & 5,153 & 4,064 & 5,277 & 4,418 & 3,439 & 3,865 & 4,048 \\
\hline Offshore & & & & & & & \\
\hline \multicolumn{8}{|l|}{ Net Exploratory Wells } \\
\hline 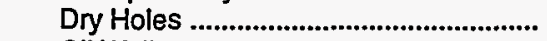 & 164 & 100 & 114 & 92 & 50 & 69 & 78 \\
\hline 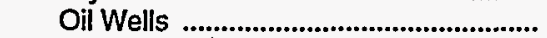 & 34 & 27 & 31 & 41 & $21^{\circ}$ & 22 & 13 \\
\hline Gas Wells & 66 & 61 & 76 & 55 & 25 & 42 & 47 \\
\hline 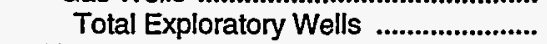 & 264 & 189 & 222 & 189 & 95 & 133 & 138 \\
\hline \multicolumn{8}{|l|}{ Net Development Wells } \\
\hline 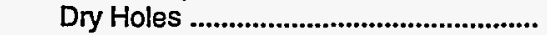 & 33 & 31 & 32 & 20 & 19 & 13 & 17 \\
\hline 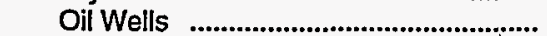 & 161 & 161 & 143 & 128 & 111 & 125 & 150 \\
\hline Gas Wells & 83 & 92 & 146 & 81 & 46 & 98 & 120 \\
\hline Total Development Wells ................... & 277 & 285 & 321 & 228 & 176 & 236 & 287 \\
\hline \multicolumn{8}{|l|}{ Total United States } \\
\hline \multicolumn{8}{|l|}{ Net Exploratory Wells } \\
\hline 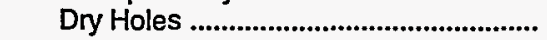 & 738 & 495 & 525 & 390 & 344 & 300 & 253 \\
\hline 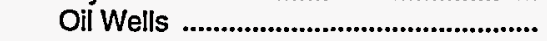 & 198 & 132 & 163 & 196 & 132 & 130 & 114 \\
\hline 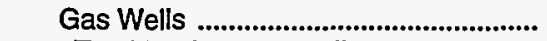 & 268 & 331 & 566 & 338 & 151 & 169 & 214 \\
\hline Total Exploratory Wells ........................ & 1,204 & 958 & 1,254 & 924 & 627 & 599 & 581 \\
\hline \multicolumn{8}{|l|}{ Net Development Wells } \\
\hline 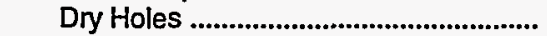 & 422 & 330 & 293 & 345 & 212 & 249 & 220 \\
\hline 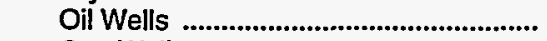 & 3,903 & 2,765 & 3,479 & 2,866 & $1, \overline{775}$ & 2,091 & 2,130 \\
\hline 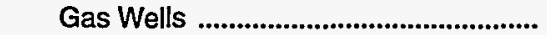 & 1,105 & 1,253 & 1,826 & 1,435 & 1,628 & 1,761 & 1,985 \\
\hline Total Development Wells ...................... & 5,430 & 4,349 & 5,598 & 4,646 & 3,615 & 4,101 & 4,335 \\
\hline \multirow{2}{*}{\multicolumn{8}{|c|}{$\begin{array}{l}\text { Number of Net In-Progress Wells } \\
\text { At Year End }\end{array}$}} \\
\hline & & & & & & & \\
\hline \multicolumn{8}{|l|}{ Onshore } \\
\hline 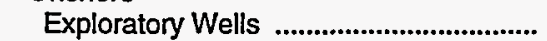 & $152^{\circ}$ & 301 & 275 & 125 & 97 & 106 & 90 \\
\hline 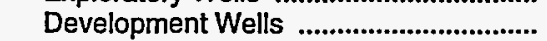 & 694 & 813 & 1,100 & 650 & 795 & 709 & 524 \\
\hline 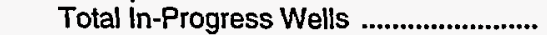 & 846 & 1,113 & 1,375 & 775 & 892 & 815 & 614 \\
\hline \multicolumn{8}{|l|}{ Offshore } \\
\hline Exploratory Wells & 73 & 62 & 72 & 49 & 39 & 35 & 46 \\
\hline 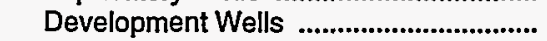 & 128 & 109 & 64 & 36 & 57 & 68 & 91 \\
\hline 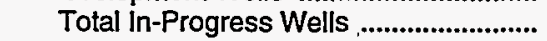 & 201 & 171 & 137 & 85 & 96 & 103 & 137 \\
\hline \multicolumn{8}{|l|}{ Total United States } \\
\hline 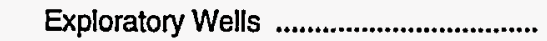 & 224 & 363 & 347 & 174 & 136. & 141 & 136 \\
\hline 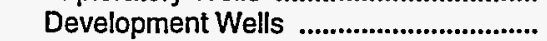 & 822 & 922 & 1,164 & 686 & 852 & 777 & 615 \\
\hline Total In-Progress Wells ............................. & 1,047 & 1,285 & 1,512 & 860 & 988 & 918 & 751 \\
\hline
\end{tabular}

Source: Energy Information Administration, Form ElA-28. 
Table B27. Exploration and Development Net Drilling Footage for FRS Companies, 1988-1994

(Thousand Feet)

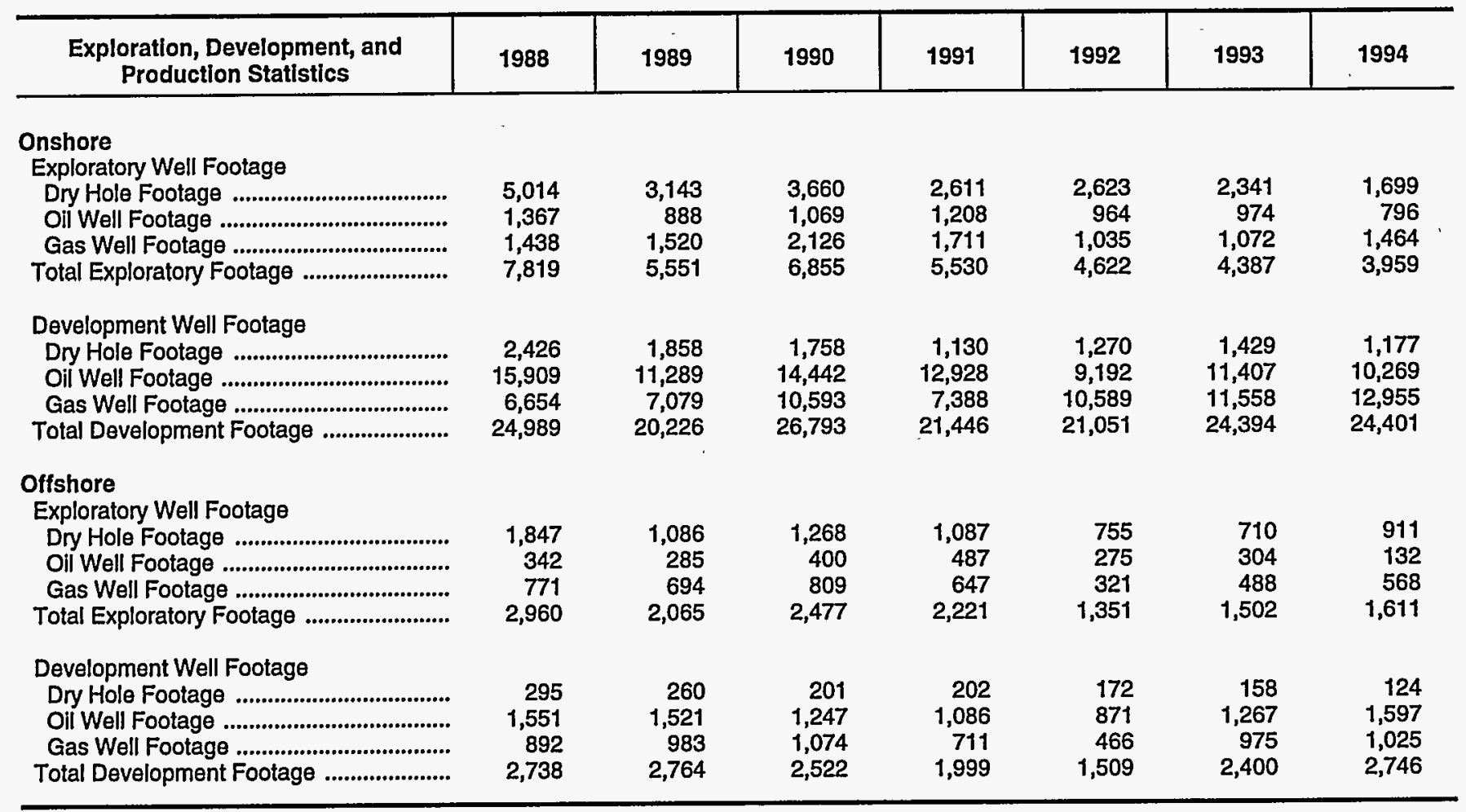

Source: Energy Information Administration, Form EIA-28. 
Table B28. U.S. Net Producing Wells and U.S. Acreage for FRS Companies, 1988-1994

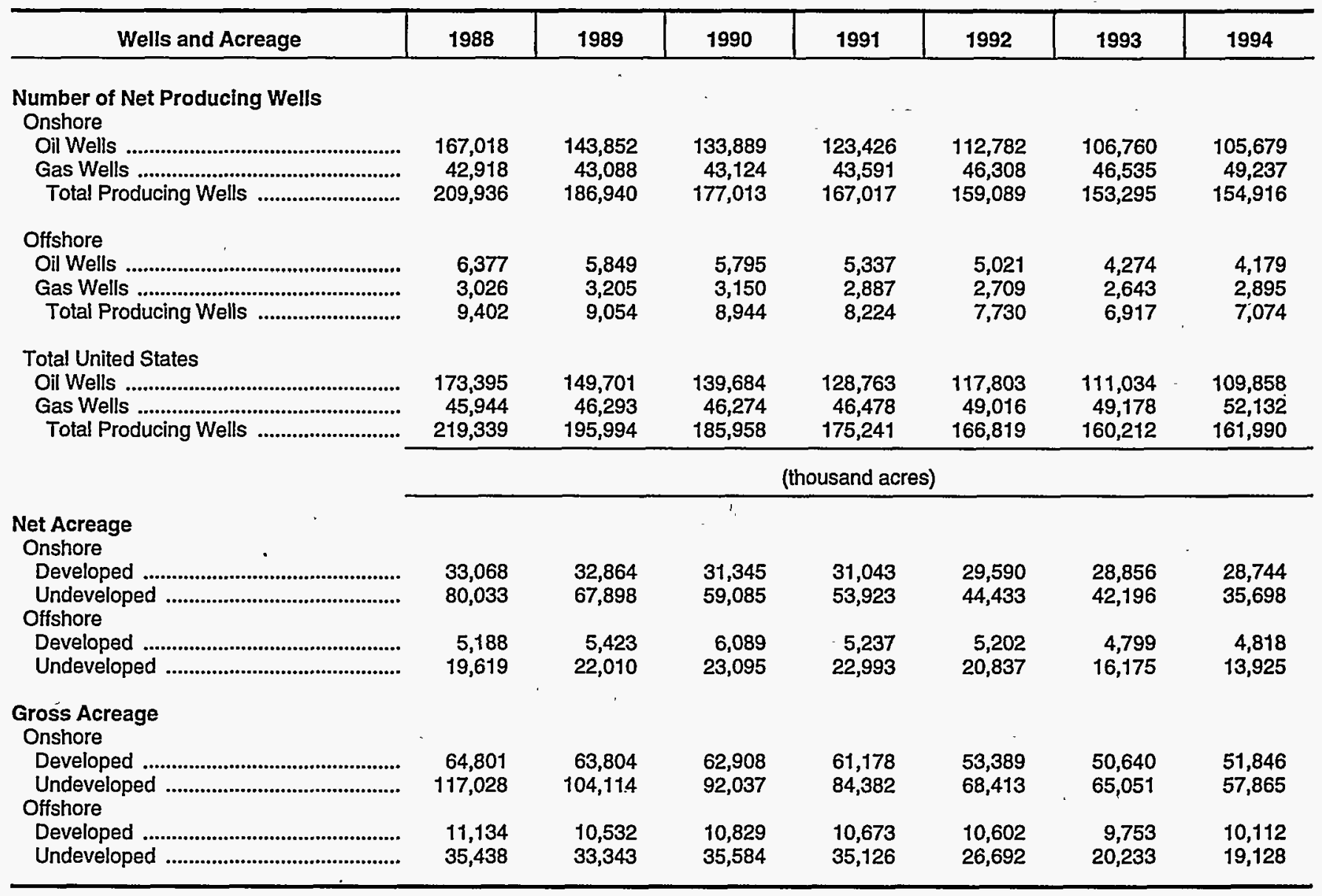

Source: Energy Information Administration, Form EIA-28. 
Table B29. U.S. Net Petroleum Acreage for FRS Companies, Ranked by Total Energy Assets, 1994 and Percent Change from 1993

\begin{tabular}{|c|c|c|c|c|c|c|}
\hline \multirow[b]{2}{*}{$\begin{array}{c}\text { Petroleum } \\
\text { Acreage }\end{array}$} & \multicolumn{2}{|c|}{ Undeveloped Acreage } & \multicolumn{2}{|c|}{ Developed Acreage } & \multicolumn{2}{|c|}{ Total Acreage } \\
\hline & $\begin{array}{c}\text { Thousand } \\
\text { Acres }\end{array}$ & $\begin{array}{c}\text { Percent } \\
\text { Change } \\
\text { from } 1993\end{array}$ & $\begin{array}{l}\text { Thousand } \\
\text { Acres }\end{array}$ & $\begin{array}{c}\text { Percent } \\
\text { Change } \\
\text { from } 1993\end{array}$ & $\begin{array}{c}\text { Thousand } \\
\text { Acres }\end{array}$ & $\begin{array}{c}\text { Percent } \\
\text { Change } \\
\text { from } 1993\end{array}$ \\
\hline 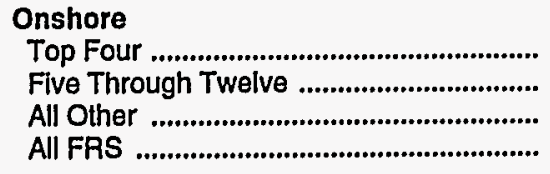 & $\begin{array}{l}11,655 \\
13,687 \\
10,356 \\
35,698\end{array}$ & $\begin{array}{r}-0.1 \\
-5.6 \\
-35.4 \\
-15.4\end{array}$ & $\begin{array}{r}9,802 \\
8,977 \\
9,965 \\
28,744\end{array}$ & $\begin{array}{r}-4.8 \\
1.2 \\
2.9 \\
-0.4\end{array}$ & $\begin{array}{l}21,457 \\
22,664 \\
20,321 \\
64,442\end{array}$ & $\begin{array}{r}-2.3 \\
-3.0 \\
-21.0 \\
-9.3\end{array}$ \\
\hline 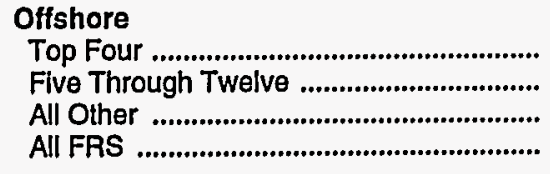 & $\begin{array}{r}3,603 \\
6,952 \\
3,370 \\
13,925\end{array}$ & $\begin{array}{r}-9.4 \\
-19.9 \\
-4.2 \\
-13.9\end{array}$ & $\begin{array}{l}2,126 \\
1,453 \\
1,239 \\
4,818\end{array}$ & $\begin{array}{r}-7.0 \\
5.1 \\
9.5 \\
0.4\end{array}$ & $\begin{array}{r}5,729 \\
8,405 \\
4,609 \\
18,743\end{array}$ & $\begin{array}{r}-8.5 \\
-16.5 \\
-0.8 \\
-10.6\end{array}$ \\
\hline 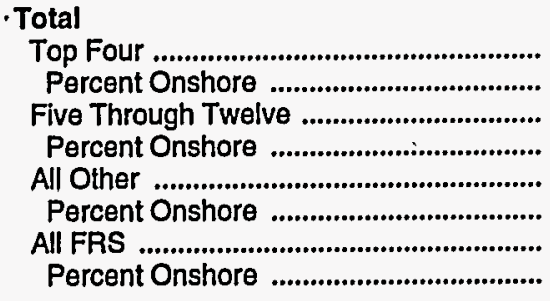 & $\begin{array}{r}15,258 \\
76.4 \\
20,639 \\
66.3 \\
13,726 \\
75.4 \\
49,623 \\
71.9\end{array}$ & $\begin{array}{r}-2.5 \\
- \\
-11 . \overline{0} \\
- \\
-29 . \overline{8} \\
-15 . \overline{0} \\
-.\end{array}$ & $\begin{array}{r}11,928 \\
82.2 \\
10,430 \\
86.1 \\
11,204 \\
88.9 \\
33,562 \\
85.6\end{array}$ & $\begin{array}{r}-5.2 \\
-. \bar{~} \\
1.7 \\
-- \\
3.6 \\
-0.3 \\
-\end{array}$ & $\begin{array}{r}27,186 \\
78.9 \\
31,069 \\
72.9 \\
24,930 \\
81.5 \\
83,185 \\
77.5\end{array}$ & $\begin{array}{r}-3.7 \\
- \\
-7.1 \\
- \\
-17.9 \\
-9.6 \\
--\end{array}$ \\
\hline
\end{tabular}

- = Not applicable.

Source: Energy Information Administration, Form EIA-28. 
Table B30. U.S. Net Ownership Interest Petroleum Reserves and Production for FRS Companies and U.S. Industry, 1994

\begin{tabular}{|c|c|c|c|c|}
\hline \multirow[t]{2}{*}{ Reserves and Production } & \multicolumn{2}{|c|}{$\begin{array}{l}\text { Crude Oll and } \\
\text { Natural Gas Liquids } \\
\text { (billion barrels) }\end{array}$} & \multicolumn{2}{|c|}{$\begin{array}{c}\text { Natural Gas } \\
\text { (trillion cubic feet) }\end{array}$} \\
\hline & $\begin{array}{c}\text { FRS } \\
\text { Companies }\end{array}$ & $\begin{array}{c}\text { U.S. } \\
\text { Industry }\end{array}$ & $\begin{array}{c}\text { FRS } \\
\text { Companies }\end{array}$ & $\begin{array}{c}\text { U.S. } \\
\text { Industry }\end{array}$ \\
\hline \multicolumn{5}{|l|}{ Onshore } \\
\hline 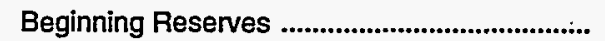 & 14.7 & 26.4 & 58.2 & 134.0 \\
\hline Ending Reserves & 14.2 & 25.8 & 57.5 & 134.2 \\
\hline Percent Change & -3.5 & -2.2 & -1.2 & 0.2 \\
\hline Production & 1.3 & 2.6 & 5.2 & 13.3 \\
\hline Percent Change from 1993 & -2.2 & -2.8 & 3.1 & 3.0 \\
\hline \multicolumn{5}{|l|}{ Offshore } \\
\hline 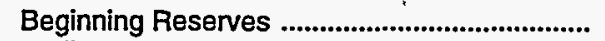 & 2.8 & 3.8. & 19.2 & 28.5 \\
\hline 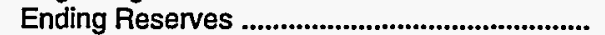 & 2.8 & 3.8 & 20.7 & 29.6 \\
\hline Percent Change ........................................................ & 1.9 & 0.7 & $7.8^{\circ}$ & 4.1 \\
\hline 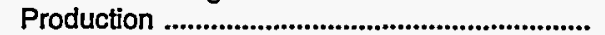 & 0.3 & 0.5 & 2.8 & 5.0 \\
\hline Percent Change from 1993 & -3.0 & 1.5 & 7.5 & 2.9 \\
\hline \multicolumn{5}{|l|}{ Total } \\
\hline Beginning Reserves & 17.5 & 30.2 & 77.5 & 162.4 \\
\hline Ending Reserves & 17.0 & 29.6 & 78.3 & 163.8 \\
\hline Percent Change & -2.6 & -1.8 & 1.0 & 0.9 \\
\hline 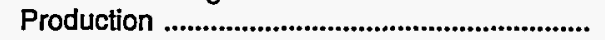 & 1.6 & 3.1 & 8.0 & 18.3 \\
\hline Percent Change from 1993 & -2.4 & -2.2 & 4.5 & 3.0 \\
\hline
\end{tabular}

Note: "Net Ownership Interest" is defined as net working interest plus own royalty interest.

Sources: Industry data - Energy Information Administration Form ElA-23; see U.S. Crude Oil, Natural Gas, and Natural Gas Liquids Reserves Annual Report, 1993 and 1994 (October 1994 and October 1995). FRS companies data - Energy Information Administration, Form EIA-28. 
Table B31. Proved Petroleum Reserves for FRS Companies, United States and Foreign, 1994

\begin{tabular}{|c|c|c|c|c|c|c|c|}
\hline \multirow{2}{*}{ Reserves Statistics } & \multirow{2}{*}{$\begin{array}{c}\text { Worldwide } \\
\text { Total }\end{array}$} & \multicolumn{3}{|c|}{ United States } & \multicolumn{3}{|c|}{ Foreign } \\
\hline & & Totál & Onshore & Offshore & Total & Canada & Other \\
\hline \multirow{3}{*}{ 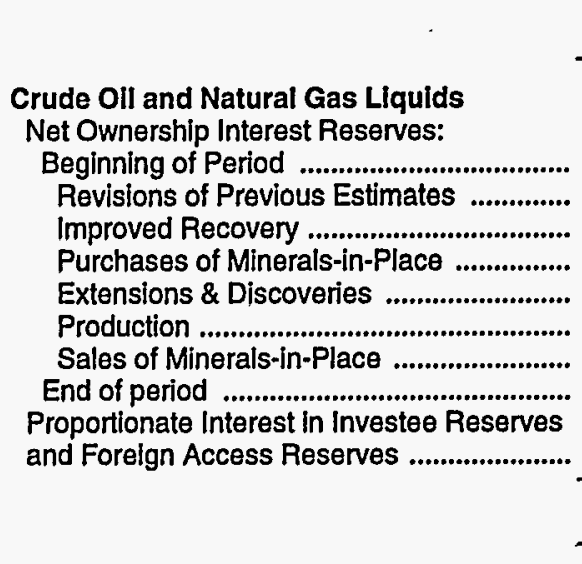 } & \multicolumn{7}{|c|}{ (million barrels) } \\
\hline & $\begin{array}{r}30,352 \\
646 \\
985 \\
366 \\
1,340 \\
-\quad-3,013 \\
-303 \\
30,374 \\
1,551\end{array}$ & $\begin{array}{r}17,473 \\
145 \\
496 \\
132 \\
521 \\
-1,594 \\
-159 \\
17,014\end{array}$ & $\begin{array}{r}14,697 \\
34 \\
495 \\
108 \\
273 \\
-1,296 \\
-126 \\
-14,185 \\
-\end{array}$ & $\begin{array}{r}2,777 \\
110 \\
1 . \\
24 \\
248 \\
-297 \\
-33 \\
2,829\end{array}$ & $\begin{array}{r}12,879 \\
502 \\
489 \\
234 \\
819 \\
-1,419 \\
-144 \\
13,359 \\
1,551\end{array}$ & $\begin{array}{r}2,017 \\
-7 \\
121 \\
15 \\
80 \\
-162 \\
-20 \\
2,044 \\
W\end{array}$ & $\begin{array}{r}10,862 \\
509 \\
368 \\
219 \\
739 \\
-1,257 \\
-124 \\
11,316 \\
W\end{array}$ \\
\hline & \multicolumn{7}{|c|}{ (billion cubic feet) } \\
\hline 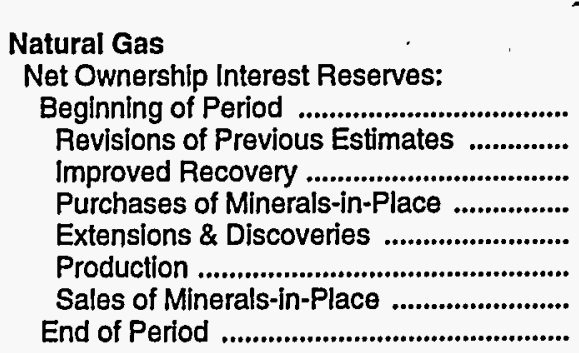 & $\begin{array}{r}134,107 \\
3,397 \\
297 \\
2,339 \\
11,518 \\
-12,311 \\
-1,578 \\
137,770\end{array}$ & $\begin{array}{r}77,487 \\
1,804 \\
93 \\
1,499 \\
6,174 \\
-7,998 \\
-760 \\
78,298\end{array}$ & $\begin{array}{r}58,243 \\
857 \\
82 \\
1,127 \\
3,141 \\
-5,244 \\
-657 \\
57,550\end{array}$ & $\begin{array}{r}19,244 \\
947 \\
10 \\
372 \\
3,033 \\
-2,754 \\
-103 \\
20,748\end{array}$ & $\begin{array}{r}56,621 \\
1,593 \\
205 \\
840 \\
5,344 \\
-4,312 \\
-818 \\
59,472\end{array}$ & $\begin{array}{r}9,911 \\
42 \\
69 \\
79 \\
1,195 \\
-937 \\
-232 \\
10,127\end{array}$ & $\begin{array}{r}46,710 \\
1,551 \\
136 \\
761 \\
4,149 \\
-3,376 \\
-585 \\
49,346\end{array}$ \\
\hline
\end{tabular}

$\ddot{\text { W }}=$ Not applicable.

$W=$ Data withheld to avoid disclosure

Source: Energy Information Administration, Form EIA-28. 
Table B32. U.S. Reserve Additions, Exploration and Development Expenditures, and Expenditures per Barrel of Reserve Additions for FRS Companies Ranked by Total Energy Assets and for U.S. Industry, 1992-1994

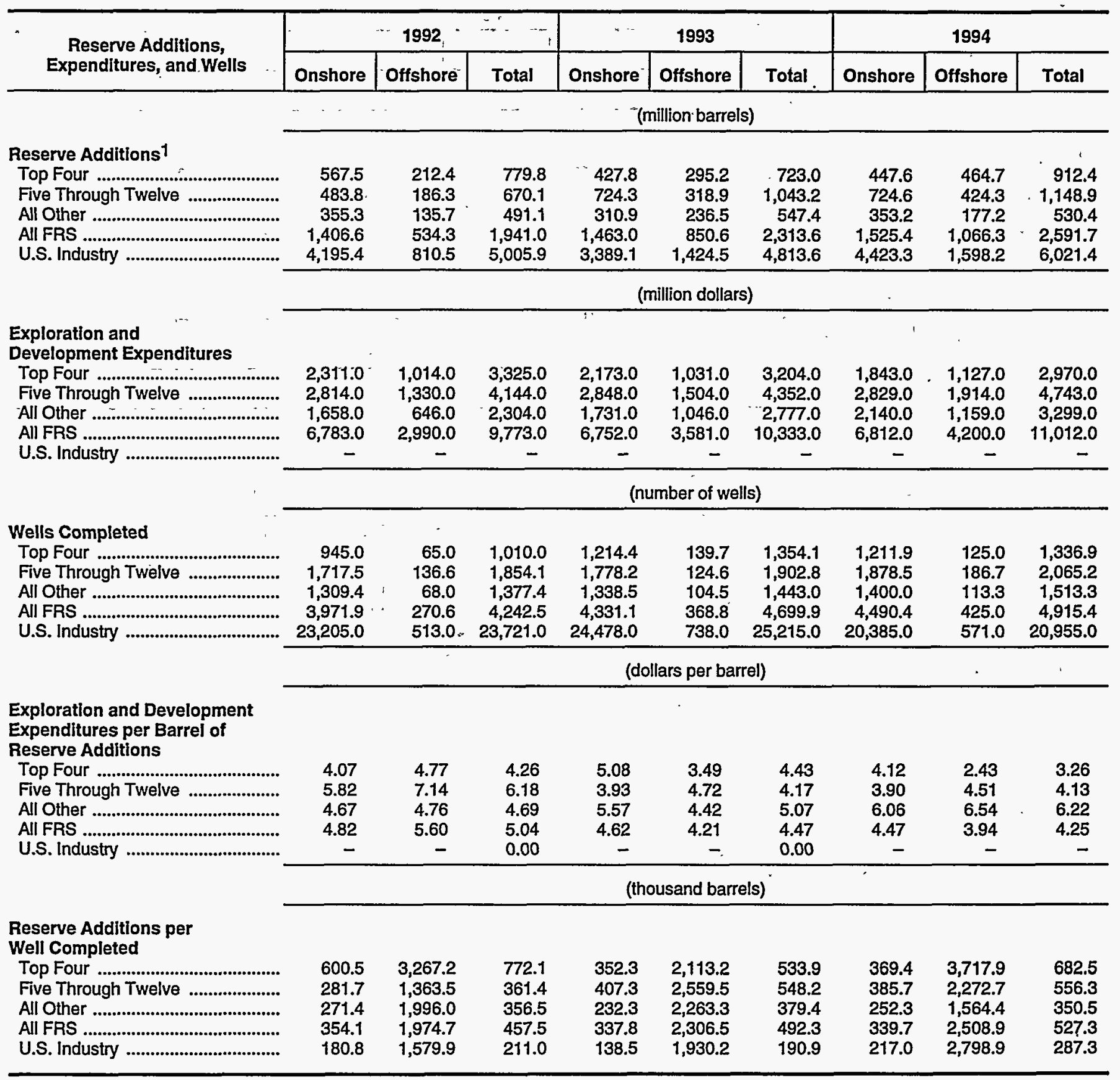

1 Excludes net purchases of minerals in place; includes crude oil and natural gas liquids (measured in millions of barrels) and natural gas (measured in millions of barrels of crude equivalent). The conversion factor for natural gas is 0.178 barrels of crude / 1000 cubic feet. Reserve additions include the net of corrections and adjustments.

$-=$ Not available.

Sources: Reserve additions - Energy Information Administration Form ElA-23; see U.S. Crude Oil, Natural Gas, and Natural Gas Liquids Reserves, 1992, 1993, and 1994 Annual Reports. Wells completed - special compilation provided by the Office of Oil and Gas, Energy Information Administration. Totals are based on data which appeared in the Energy Information's Monthly Energy Review, August 1995, p. 83. FRS companies data - Energy Information Administration, Form ElA-28. 
Table B33. Foreign Petroleum Exploration, Development, Reserves, and Production Statistics by Geographic Area for FRS Companies and Foreign Industry, 1994, and Percent Change from 1993

\begin{tabular}{|c|c|c|c|c|c|c|c|}
\hline $\begin{array}{c}\text { Forelgn Petroleum } \\
\text { Activitles }\end{array}$ & $\begin{array}{l}\text { Total } \\
\text { Forelgn }\end{array}$ & Canada & $\begin{array}{c}\text { Europe and } \\
\text { Former } \\
\text { Soviet } \\
\text { Union } 1\end{array}$ & Africa & $\begin{array}{l}\text { Middle } \\
\text { East }\end{array}$ & $\begin{array}{c}\text { Other } \\
\text { Eastern } \\
\text { Hemisphere }\end{array}$ & $\begin{array}{c}\text { Other-- } \\
\text { Western } \\
\text { Hemisphere }\end{array}$ \\
\hline $\begin{array}{l}\text { Crude Oil and NGL Production2 } \\
\text { (million barrels) }\end{array}$ & & & & & & & \\
\hline $\begin{array}{c}\text { FRS Companies } \\
\text { Percent Change } \\
\text { Foreign Industry } \\
\text { Percent Change }\end{array}$ & $\begin{array}{r}1,449.5 \\
8.4 \\
20,219.2 \\
2.0\end{array}$ & $\begin{array}{r}162.4 \\
-3.5 \\
832.2 \\
4.4\end{array}$ & $\begin{array}{r}575.9 \\
25.5 \\
4,998.7 \\
2.1\end{array}$ & $\begin{array}{r}236.4 \\
0.9 \\
2,503.9 \\
-2.1\end{array}$ & $\begin{array}{r}112.0 \\
6.2 \\
7,252.6 \\
1.6\end{array}$ & $\begin{array}{r}271.7 \\
-4.5 \\
1,527.5 \\
4.0\end{array}$ & $\begin{array}{r}91.2 \\
6.2 \\
3,104.3 \\
4.7\end{array}$ \\
\hline \multicolumn{8}{|l|}{ Wells Completed } \\
\hline $\begin{array}{c}\text { FRS Companies } \\
\text { Percent Change } \\
\text { Foreign Industry } \\
\text { Percent Change }\end{array}$ & $\begin{array}{r}1,569.0 \\
4.6 \\
17,948.0 \\
20.4\end{array}$ & $\begin{array}{r}908.7 \\
8.0 \\
11,892.0 \\
26.6\end{array}$ & $\begin{array}{r}144.6 \\
-4.9 \\
1,210.0 \\
-7.7\end{array}$ & $\begin{array}{r}92.4 \\
20.2 \\
521.0 \\
-5.6\end{array}$ & $\begin{array}{r}73.2 \\
26.9 \\
457.0 \\
68.6\end{array}$ & $\begin{array}{r}240.3 \\
-9.3 \\
1,148.0 \\
-18.5\end{array}$ & $\begin{array}{r}109.8 \\
2.6 \\
2,720.0 \\
37.7\end{array}$ \\
\hline 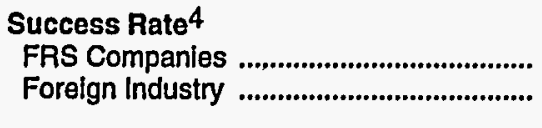 & $\begin{array}{l}80.3 \\
80.3\end{array}$ & $\begin{array}{l}81.2 \\
77.5\end{array}$ & $\begin{array}{l}75.7 \\
81.2\end{array}$ & $\begin{array}{l}63.5 \\
79.8\end{array}$ & $\begin{array}{l}90.0 \\
89.3\end{array}$ & $\begin{array}{l}78.1 \\
81.9\end{array}$ & $\begin{array}{l}91.4 \\
90.3\end{array}$ \\
\hline \multicolumn{8}{|l|}{$\begin{array}{l}\text { Exploration and Development } \\
\text { Expenditures } \\
\text { (million dollars) }\end{array}$} \\
\hline 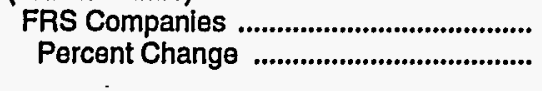 & $\begin{array}{r}11,909.0 \\
-5.1\end{array}$ & $\begin{array}{r}1,835.0 \\
17.7\end{array}$ & $\begin{array}{r}4,736.0 \\
-17.6\end{array}$ & $\begin{array}{r}1,392.0 \\
-5.4\end{array}$ & $\begin{array}{r}445.0 \\
-35.0\end{array}$ & $\begin{array}{r}2,758.0 \\
11.7\end{array}$ & $\begin{array}{r}743.0 \\
20.6\end{array}$ \\
\hline \multicolumn{8}{|l|}{$\begin{array}{l}\text { Crude Oll and NGL Reserve } \\
\text { Interests } \\
\text { (million barrels) }\end{array}$} \\
\hline 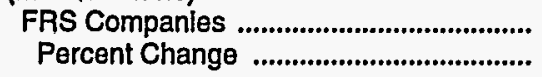 & $\begin{array}{r}14,910.8 \\
3.0\end{array}$ & $\begin{array}{r}2,049.1 \\
1.4\end{array}$ & $\begin{array}{r}5,569.5 \\
0.7\end{array}$ & $\begin{array}{r}2,464.9 \\
17.4\end{array}$ & $\begin{array}{r}1,753.7 \\
2.8\end{array}$ & $\begin{array}{r}2,241.8 \\
-5.8\end{array}$ & $\begin{array}{r}831.9 \\
13.2\end{array}$ \\
\hline
\end{tabular}

1 OECD Europe combined with the former Soviet Union and Eastem Europe to avoid disclosure. Prior to 1993, only OECD Europe is included in this region.

2 Crude oil plus natural gas liquids. Includes ownership interest production and foreign access production.

3 Foreign Industry levels defined as total activity outside of the United States except the People's Republic of China.

4 Success Rate defined as the total number of successful well completions during the period divided by the total number of wells drilled.

5 Includes net ownership interest reserves (89.0 percent) and "Other Access" reserves (11.0 percent). "Other Access" reserves include proportional interest in investee reserves and foreign access reserves.

Note: Sum of components may not equal total due to independent rounding.

Sources: FRS Companies - Energy Information Administration, Form EIA-28. Industry data - World Oil, August 1995, and Energy Information Administration, Intemational Energy Annual, 1994. 
Table B34. Foreign Exploration and Development Expenditures by Region.for FRS Companies, 1988-1994 (Million Dollars)

\begin{tabular}{|c|c|c|c|c|c|c|c|}
\hline Forelgn Expenditures by Region & 1988 & 1989 & 1990 & 1991 & 1992 & 1993 & 1994 \\
\hline \multicolumn{8}{|l|}{ Exploration Expenditures } \\
\hline 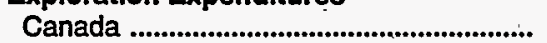 & 1,124 & 1,141 & 753 & 661 & 336 & 403 & 573 \\
\hline OECD Europe & 1,465 & 1,132 & 2,233 & 2,192 & 1,544 & 1,313 & 1,063 \\
\hline Former Soviet Union and E. Europe ........ & 0 & & 0 & 0 & 0 & 163 & 204 \\
\hline Africa & 494 & 585 & 618 & 680 & 738 & 599 & 678 \\
\hline 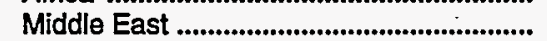 & 223 & 197 & 302 & 258 & 273 & 225 & 104 \\
\hline Other Eastem Hemisphere ........................... & 604 & 1,186 & 1,017 & 1,028 & 869 & 736 & 888 \\
\hline Other Westem Hemisphere ....................... & 316 & 304 & 327 & 435 & 283 & 240 & 320 \\
\hline Total Foreign Exploration Expenditures .... & 4,226 & 4,545 & 5,250 & 5,254 & 4,043 & 3,679 & 3,830 \\
\hline \multicolumn{8}{|l|}{ Development Expenditures } \\
\hline 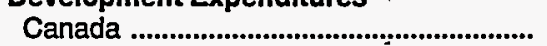 & 4,277 & 5,125 & 1,065 & 1,070 & 770 & 1,156 & 1,262 \\
\hline OECD Europe & 2,854 & 2,407 & 4,383 & 4,643 & 5,252 & 4,169 & 3,376 \\
\hline Former Soviet Union and E. Europe ........ & & 0 & 0 & 0 & 0 & 100 & 93 \\
\hline Africa & 346 & 439 & 807 & 845 & 655 & 873 & 714 \\
\hline 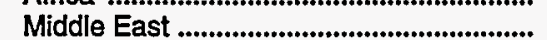 & 153 & 209 & 296 & 233 & 285 & 460 & 341 \\
\hline Other Eastem Hemisphere ........................ & 765 & 1,098 & 1,416 & 1,359 & 1,540 & 1,733 & 1,870 \\
\hline Other Westem Hemisphere ......................... & 419 & 305 & 343 & 300 & 364 & 376 & 423 \\
\hline Total Foreign Development Expenditures & 8,814 & 9,583 & 8,310 & 8,450 & 8,866 & 8,867 & 8,079 \\
\hline \multicolumn{8}{|l|}{$\begin{array}{l}\text { Total Exploration and Development } \\
\text { Expenditures }\end{array}$} \\
\hline 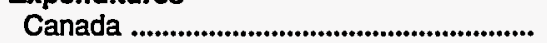 & $5,401^{\circ}$ & 6,266 & 1,818 & 1,731 & 1,106 & 1,559 & 1,835 \\
\hline OECD Europe & 4,319 & 3,539 & 6,616 & 6,835 & 6,796 & 5,482 & 4,439 \\
\hline Former Soviet Union and E. Europe ........ & 0 & & & & 0 & 263 & 297 \\
\hline Africa ........................................................... & 840 & 1,024 & 1,425 & 1,525 & 1,393 & 1,472 & 1,392 \\
\hline 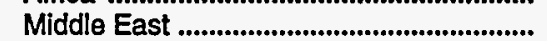 & 376 & 406 & 598 & 491 & 558 & 685 & 445 \\
\hline Other Eastern Hemisphere ......................... & 1,369 & 2,284 & 2,433 & 2,387 & 2,409 & 2,469 & 2,758 \\
\hline 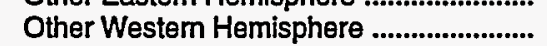 & 735 & 609 & 670 & 735 & 647 & 616 & 743 \\
\hline Total Foreign Exploration and & & & & & & & \\
\hline Development Expenditures ........................... & 13,040 & 14,128 & 13,560 & 13,704 & 12,909 & 12,546 & 11,909 \\
\hline
\end{tabular}

Source: Energy Information Administration, Form ElA-28. 
Table B35. Distribution of Foreign Exploration and Development Expenditures for FRS Companies Ranked by Total Energy Assets, 1994, and Percent Change from 1993

\begin{tabular}{|c|c|c|c|c|c|c|}
\hline $\begin{array}{l}\text { Exploration and Development } \\
\text { Expenditures }\end{array}$ & $\begin{array}{c}\text { Total } \\
\text { Foreign }\end{array}$ & Canada & $\begin{array}{c}\text { Europe and } \\
\text { Former } \\
\text { Soviet Union } 1\end{array}$ & $\begin{array}{l}\text { Africa } \\
\text { and } \\
\text { Mideast }\end{array}$ & $\begin{array}{c}\text { Other } \\
\text { Eastern } \\
\text { Hemisphere }\end{array}$ & $\begin{array}{c}\text { Other } \\
\text { Western } \\
\text { Hemisphere }\end{array}$ \\
\hline & \multicolumn{6}{|c|}{ (million dollars) } \\
\hline 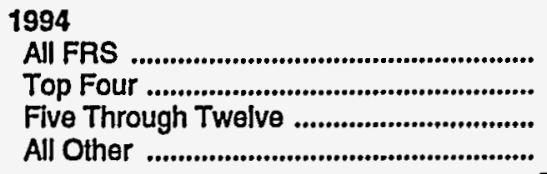 & $\begin{array}{r}11,909.0 \\
6,180.0 \\
3,914.0 \\
1,815.0\end{array}$ & $\begin{array}{r}1,835.0 \\
1,002.0 \\
537.0 \\
296.0\end{array}$ & $\begin{array}{r}4,736.0 \\
2,520.0 \\
1,351.0 \\
865.0\end{array}$ & $\begin{array}{r}1,837.0 \\
957.0 \\
734.0 \\
146.0\end{array}$ & $\begin{array}{r}2,758.0 \\
1,599.0 \\
702.0 \\
457.0\end{array}$ & $\begin{array}{r}743.0 \\
102.0 \\
590.0 \\
51.0\end{array}$ \\
\hline & \multicolumn{6}{|c|}{ (percent) } \\
\hline DIstribution 1994 & & & & & & \\
\hline 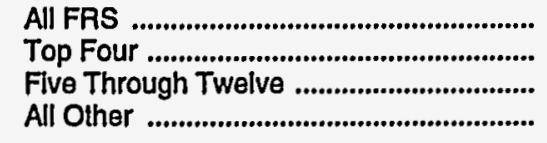 & $\begin{array}{l}100.0 \\
100.0 \\
100.0 \\
100.0\end{array}$ & $\begin{array}{l}15.4 \\
16.2 \\
13.7 \\
16.3\end{array}$ & $\begin{array}{l}39.8 \\
40.8 \\
34.5 \\
47.7\end{array}$ & $\begin{array}{r}15.4 \\
15.5 \\
18.8 \\
8.0\end{array}$ & $\begin{array}{l}23.2 \\
25.9 \\
17.9 \\
25.2\end{array}$ & $\begin{array}{r}6.2 \\
1.7 \\
15.1 \\
2.8\end{array}$ \\
\hline 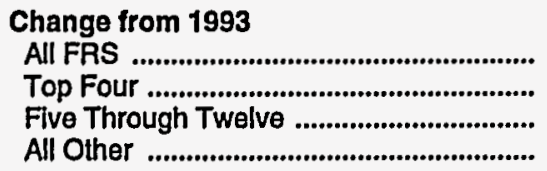 & $\begin{array}{r}-5.1 \\
2.0 \\
-13.6 \\
-7.3\end{array}$ & $\begin{array}{r}17.7 \\
8.4 \\
32.3 \\
29.3\end{array}$ & $\begin{array}{l}-17.6 \\
-10.2 \\
-22.0 \\
-28.3\end{array}$ & $\begin{array}{r}-14.8 \\
14.9 \\
-36.8 \\
-10.4\end{array}$ & $\begin{array}{l}11.7 \\
13.0 \\
-4.9 \\
44.6\end{array}$ & $\begin{array}{l}20.6 \\
24.4 \\
20.4 \\
15.9\end{array}$ \\
\hline
\end{tabular}

1 OECD Europe combined with the former Soviet Union and Eastem Europe to avoid disclosure. Prior to 1993, only OECD Europe is included in this region.

Source: Energy Information Administration, Form EIA-28. 
Table B36. Number of Net Wells Completed, Net In-Progress Wells, and Net Producing Wells in Foreign Areas for FRS Companies, 1988-1994

\begin{tabular}{|c|c|c|c|c|c|c|c|}
\hline Number of Wells & 1988 & 1989 & 1990 & 1991 & 1992 & 1993 & 1994 \\
\hline \multicolumn{8}{|l|}{ Canada } \\
\hline \multicolumn{8}{|l|}{$\begin{array}{l}\text { Net Wells Completed During Year } \\
\text { Exploratory Wells }\end{array}$} \\
\hline 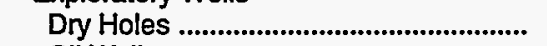 & 155.3 & 113.9 & 104.9 & 101.3 & 65.1 & 71.7 & 111.2 \\
\hline 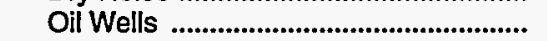 & 84.1 & 56.3 & 61.7 & 38.2 & 19.7 & 47.9 & 42.0 \\
\hline 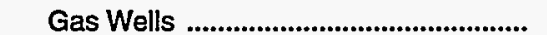 & 54.5 & 38.3 & 48.3 & 54.0 & 29.6 & 46.8 & 105.1 \\
\hline Total Exploratory Wells ......................... & 293.9 & 208.5 & 214.9 & 193.5 & 114.4 & 166.4 & 258.3 \\
\hline \multicolumn{8}{|l|}{ Development Wells } \\
\hline 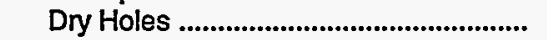 & 58.2 & 34.7 & 47.2 & 32.3 & 29.3 & 47.4 & 59.6 \\
\hline 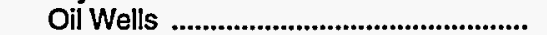 & 690.8 & 168.3 & 225.7 & 169.6 & 211.1 & 334.6 & 174.2 \\
\hline 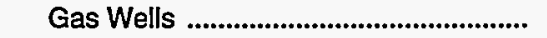 & 66.6 & 39.8 & 97.1 & 97.0 & 39.4 & 292.9 & 416.6 \\
\hline Total Development Wells .................... & 815.6 & 242.8 & 370.0 & 298.9 & 279.8 & 674.9 & 650.4 \\
\hline Net In-Progress Wells at Year End ........... & 163.5 & 126.3 & 63.9 & 29.3 & 31.7 & 65.3 & 57.6 \\
\hline \multicolumn{8}{|l|}{ Net Producing Wells } \\
\hline 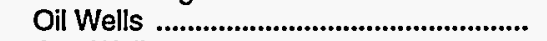 & $16,087.6$ & $15,880.1$ & $15,044.9$ & $13,996.6$ & $12,597.5$ & $11,704.3$ & $11,268,5$ \\
\hline Gas Wells & $7,795.9$ & $7,162.6$ & $6,635.8$ & $6,094.0$ & $5,927.2$ & $5,740.2$ & $5,953.3$ \\
\hline Total Producing Wells ................................... & $23,883.5$ & $23,042.7$ & $21,680.7$ & $20,090.6$ & $18,524.7$ & $17,444.5$ & $17,221.8$ \\
\hline \multirow{3}{*}{\multicolumn{8}{|c|}{$\begin{array}{l}\text { Europe and Former Soviet Union } 1 \\
\text { Net Wells Completed During Year } \\
\text { Exploratory Wells }\end{array}$}} \\
\hline & & & & & & & \\
\hline & & & & & & & \\
\hline 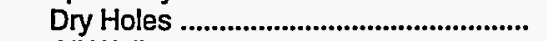 & 68.5 & 75.1 & 74.9 & 77.6 & 47.4 & 33.4 & 33.7 \\
\hline 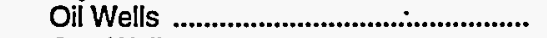 & 15.8 & 13.7 & 16.1 & 8.2 & 16.2 & 11.8 & 13.3 \\
\hline 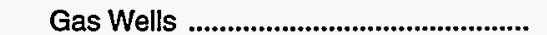 & 20.1 & 14.9 & 15.9 & 15.0 & 11.8 & 14.6 & 11.2 \\
\hline Total Exploratory Wells ........................ & 104.4 & 103.7 & 106.9 & 100.8 & 75.4 & 59.8 & 58.2 \\
\hline \multicolumn{8}{|l|}{ Development Wells } \\
\hline 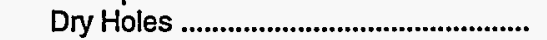 & 8.6 & 4.9 & 3.7 & 5.4 & 2.6 & 3.6 & 1.5 \\
\hline 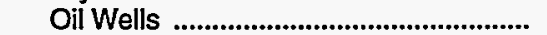 & 54.1 & 52.3 & 54.4 & 52.0 & 38.2 & 59.9 & 60.4 \\
\hline 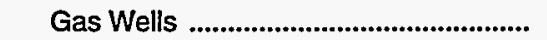 & 25.4 & 27.1 & 22.5 & - $\quad 26.5$ & 25.8 & 28.8 & 24.5 \\
\hline Total Development Wells .................... & 88.1 & 84.3 & 80.6 & 83.9 & 66.6 & 92.3 & 86.4 \\
\hline Net In-Progress Wells at Year End .......... & 83.5 & 65.6 & 78.4 & 77.0 & 70.5 & 76.3 & 74.5 \\
\hline \multicolumn{8}{|l|}{ Net Producing Wells } \\
\hline 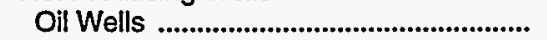 & $1,532.9$ & $1,436.8$ & $1,475.8$ & $1,462.0$ & $1,459.3$ & $1,479.3$ & $1,430.2$ \\
\hline 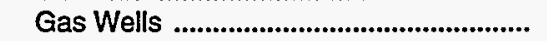 & 586.1 & 621.7 & 643.6 & 645.4 & 647.5 & 687.0 & 720.7 \\
\hline Total Producing Wells ............................. & $2,119.0$ & $2,058.5$ & $2,119.4$ & $2,107.4$ & $2,106.8$ & $2,166.3$ & $2,150.9$ \\
\hline \multicolumn{8}{|l|}{ Africa and Middle East } \\
\hline \multicolumn{8}{|l|}{ Net Wells Completed During Year } \\
\hline \multicolumn{8}{|l|}{ Exploratory Wells } \\
\hline 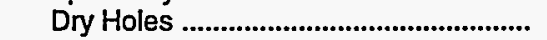 & 55.3 & 37.8 & 51.4 & 54.5 & 65.3 & 37.9 & 32.0 \\
\hline Oil Wells & w & 14.5 & W & W & $\mathbf{w}$ & W & W \\
\hline 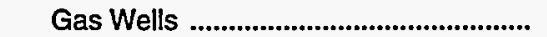 & W & 1.7 & W & W & $W$ & W & W \\
\hline Total Exploratory Wells ............................ & 74.3 & 54.0 & 67.5 & 73.9 & 84.8 & 52.8 & 47.9 \\
\hline \multicolumn{8}{|l|}{ Development Wells } \\
\hline 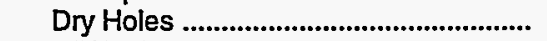 & $w$ & W & 6.6 & $W$ & W & W & W \\
\hline 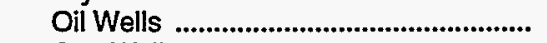 & 79.0 & 85.6 & 77.5 & 82.7 & 91.1 & 72.2 & 105.7 \\
\hline 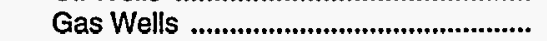 & W & $W$ & 2.0 & W & W & W & $w$ \\
\hline Total Development Wells ..................... & 95.0 & 93.1 & 86.1 & 94.1 & 103.5 & 81.8 & 117.7 \\
\hline Net In-Progress Wells at Year End .......... & 47.0 & 48.0 & 29.0 & 44.0 & 34.4 & 21.3 & 45.1 \\
\hline \multicolumn{8}{|l|}{ Net Producing Wells } \\
\hline Oil Wells & $1,332.1$ & $1,349.2$ & $1,240.7$ & $1,294.2$ & $1,374.1$ & 1,322.9 & $1,442.2$ \\
\hline 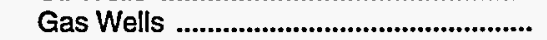 & 19.9 & 20.4 & 20.0 & 20.6 & 26.8 & 25.8 & 34.4 \\
\hline Total Producing Wells ............................... & $1,352.0$ & $1,369.6$ & $1,260.7$ & $1,314.8$ & $1,400.9$ & $1,348.7$ & $1,476.6$ \\
\hline
\end{tabular}

See footnotes at end of table. 
Table B36. Number of Net Wells Completed, Net In-Progress Wells, and Net Producing Wells in Foreign Areas for FRS Companies, 1988-1994 (Continued)

\begin{tabular}{|c|c|c|c|c|c|c|c|}
\hline Number of Wells & 1988 & 1989 & 1990 & 1991 & 1992 & 1993 & 1994 \\
\hline \multicolumn{8}{|l|}{$\begin{array}{l}\text { Other Eastern Hemlsphere } \\
\text { Net Wells Completed During Year } \\
\text { Exploratory Wells }\end{array}$} \\
\hline 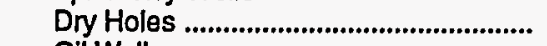 & 70.4 & 61.1 & 57.4 & 60.5 & 47.6 & 43.9 & 47.4 \\
\hline 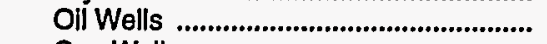 & 16.9 & 19.9 & 18.0 & 21.1 & 22.9 & 8.3 & 11.6 \\
\hline 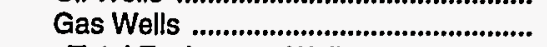 & 22.1 & 15.2 & 11.0 & 11.4 & 10.0 & 16.4 & 14.5 \\
\hline $\begin{array}{l}\text { Total Exploratory Wells } \\
\text { Develo......................... }\end{array}$ & 109.4 & 96.2 & 86.4 & 93.0 & 80.5 & 68.6 & 73.5 \\
\hline 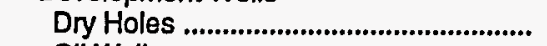 & 2.9 & 5.5 & 4.5 & 14.5 & 11.0 & 8.7 & 5.2 \\
\hline 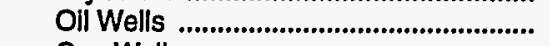 & 105.9 & 130.1 & 124.6 & 106.4 & 106.7 & 124.9 & 115.7 \\
\hline 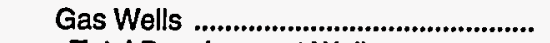 & 29.8 & 41.3 & 47.2 & 48.6 & 71.9 & 62.7 & 45.9 \\
\hline Total Development Wells ...................... & 138.6 & 176.9 & 176.3 & 169.5 & 189.6 & 196.3 & 166.8 \\
\hline $\begin{array}{l}\text { Net In-Progress Wells at Year End .......... } \\
\text { Net Producing Wells }\end{array}$ & 58.9 & 65.4 & 85.5 & 89.4 & 71.5 & 83.8 & 71.9 \\
\hline 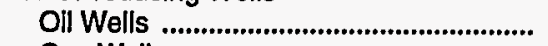 & $1,312.2$ & $1,468.3$ & $1,632.9$ & $1,532.1$ & $1,650.2$ & $1,666.0$ & $1,714.9$ \\
\hline 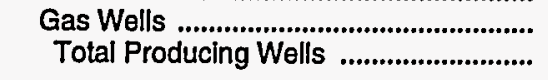 & $\begin{array}{r}271.9 \\
1,584.1\end{array}$ & $\begin{array}{r}279.8 \\
1,748.1\end{array}$ & $\begin{array}{r}324.8 \\
1,957.7\end{array}$ & $\begin{array}{r}321.1 \\
1,853.2\end{array}$ & $\begin{array}{r}373.2 \\
2,023.4\end{array}$ & $\begin{array}{r}393.9 \\
2,059.9\end{array}$ & $\begin{array}{r}437.9 \\
2,152.8\end{array}$ \\
\hline \multicolumn{8}{|l|}{$\begin{array}{l}\text { Other Western Hemisphere } \\
\text { Net Wells Completed During Year } \\
\text { Exploratory Wells }\end{array}$} \\
\hline 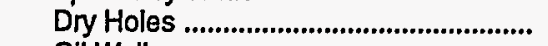 & 16.7 & 22.6 & 19.7 & 15.1 & 6.9 & 8.1 & 7.5 \\
\hline 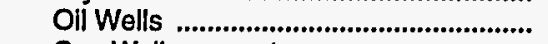 & w & W & W & $w$ & W & $w$ & $w$ \\
\hline 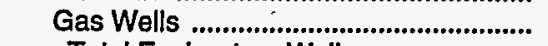 & $W$ & $W$ & W & W & $w$ & W & $W$ \\
\hline $\begin{array}{l}\text { Total Exploratory Wells ......................... } \\
\text { Development Wells }\end{array}$ & 24.5 & 30.2 & 22.7 & 25.6 & 12.0 & 19.8 & 15.5 \\
\hline 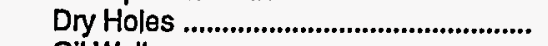 & $w$ & 5.0 & $w$ & $w$ & $w$ & $w$ & $w$ \\
\hline 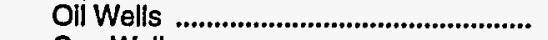 & 140.6 & 119.5 & 87.4 & 87.4 & 87.0 & 78.8 & 85.6 \\
\hline 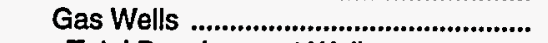 & $W$ & 0.0 & w & W & $w$ & $W$ & $W$ \\
\hline 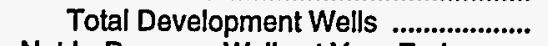 & 141.4 & 124.5 & 89.9 & 93.4 & 89.0 & 87.2 & 94.3 \\
\hline $\begin{array}{l}\text { Net In-Progress Wells at Year End .......... } \\
\text { Net Producing Wells }\end{array}$ & 35.0 & 10.3 & 15.1 & 9.6 & 7.4 & 15.6 & 14.8 \\
\hline 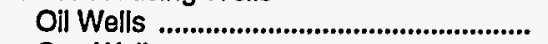 & $3,277.0$ & $3,276.8$ & $3,102.0$ & $3,145.5$ & $2,938.3$ & $3,032.6$ & $2,939.6$ \\
\hline 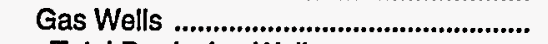 & 92.3 & 88.4 & 48.4 & 44.5 & 42.0 & 65.4 & 48.7 \\
\hline Total Producing Welis .............................. & $3,369.3$ & $3,365.2$ & $3,150.4$ & $3,190.0$ & $2,980.3$ & $3,098.0$ & $2,988.3$ \\
\hline \multicolumn{8}{|l|}{ Total Foreign } \\
\hline \multicolumn{8}{|l|}{$\begin{array}{l}\text { Net Wells Completed During Year } \\
\text { Exploratory Wells }\end{array}$} \\
\hline 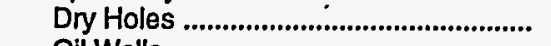 & 366.2 & $310.5^{\circ}$ & 308.3 & 309.0 & 232.3 & 195.0 & 231.8 \\
\hline 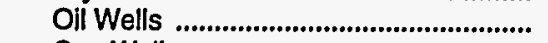 & 139.7 & 107.9 & 112.7 & 95.5 & 81.0 & 93.0 & 88.5 \\
\hline 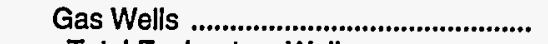 & 100.6 & 74.2 & 77.4 & 82.3 & 53.8 & 79.4 & 133.1 \\
\hline $\begin{array}{l}\text { Total Exploratory Wells ........................ } \\
\text { Development Wells }\end{array}$ & 606.5 & 492.6 & 498.4 & 486.8 & 367.1 & 367.4 & 453.4 \\
\hline 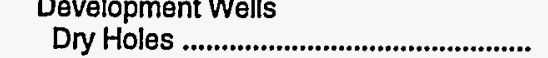 & 84.1 & 57.2 & 64.5 & \multicolumn{4}{|c|}{ Development Wells } \\
\hline 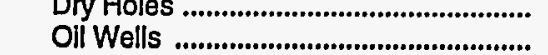 & $1,070.4$ & 555.8 & 569.6 & 498.1 & $\begin{array}{r}52.2 \\
534.1\end{array}$ & 71.1 & $\begin{array}{r}77.2 \\
5416\end{array}$ \\
\hline 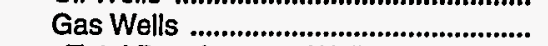 & 124.2 & 108.6 & 168.8 & 180.4 & $\begin{array}{l}534.1 \\
142.2\end{array}$ & $\begin{array}{l}670.4 \\
391.0\end{array}$ & $\begin{array}{l}541.6 \\
496.8\end{array}$ \\
\hline Total Development Wells ......................... & $1,278.7$ & 721.6 & 802.9 & 739.8 & 728.5 & $1,132.5$ & $1,115.6$ \\
\hline $\begin{array}{l}\text { Net In-Progress Wells at Year End .......... } \\
\text { Net Producing Wells }\end{array}$ & 387.9 & 315.6 & 271.9 & 249.3 & 215.5 & 262.3 & 263.9 \\
\hline 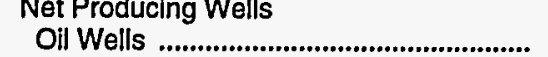 & $23,541.8$ & $23,411.2$ & $22,496.3$ & & & & \\
\hline Oil Wells & $8,766.1$ & $8,172.9$ & $7,672.6$ & $\begin{array}{r}21,430.4 \\
7,125.6\end{array}$ & $\begin{array}{r}20,019.4 \\
7,016.7\end{array}$ & $\begin{array}{r}19,205.1 \\
6,912.3\end{array}$ & $\begin{array}{r}18,795.4 \\
7,195.0\end{array}$ \\
\hline Total Producing Wells .............................. & $32,307.9$ & $31,584.1$ & $30,168.9$ & $28,556.0$ & $27,036.1$ & $26,117.4$ & $25,990.4$ \\
\hline
\end{tabular}

1 OECD Europe combined with the former Soviet Union and Eastern Europe to avoid disclosure. Prior to 1993, only OECD Europe is included in this region.

= Data withheld to avoid disclosure.

Source: Energy Information Administration, Form ElA-28. 
Table B37. Foreign Proved Oil and Gas Reserves for FRS Companies, 1994

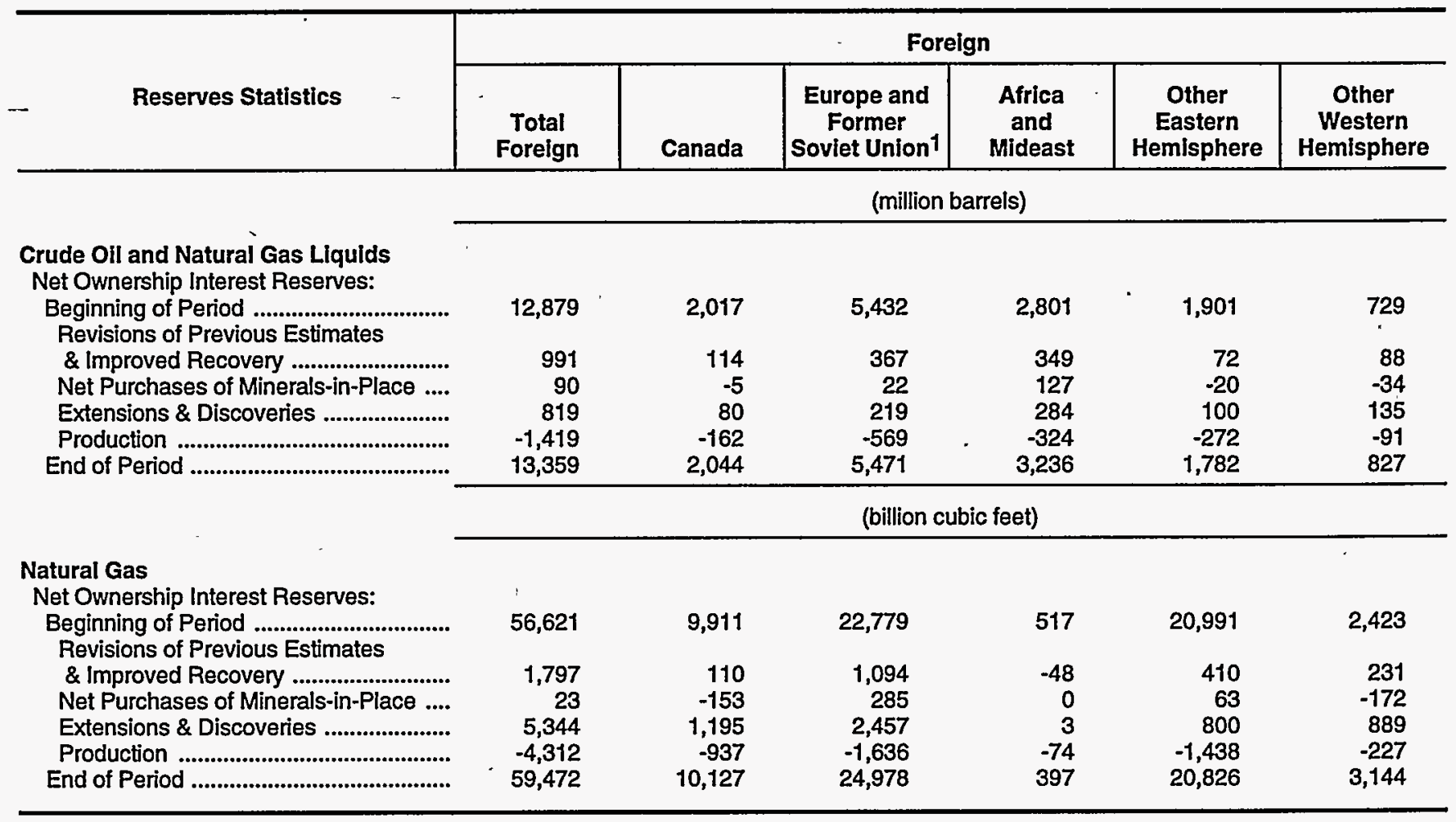

1 OECD Europe combined with the former Soviet Union and Eastem Europe to avoid disclosure. Prior to 1993, only OECD Europe is included in this region.

W = Data withheld to avoid disclosure.

Source: Energy Information Administration, Form EIA-28. 
Table B38. Foreign Production (Lifting) Costs for FRS Companies, 1988-1994

(Million Dollars)

\begin{tabular}{|c|c|c|c|c|c|c|c|}
\hline Production Costs by Region & 1988 & 1989 & 1990 & 1991 & 1992 & 1993 & 1994 \\
\hline \multicolumn{8}{|l|}{ Canada } \\
\hline 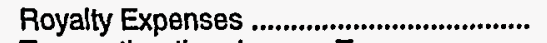 & $W$ & 19 & $W$ & $W$ & $W$ & $W$ & W \\
\hline Taxes other than Income Taxes ................. & $W$ & 94 & $w$ & $W$ & W & W & $W$ \\
\hline Other Costs & 1,323 & 1,528 & 1,736 & 1,797 & 1,388 & 1,210 & 1,141 \\
\hline Total Production Costs .............................. & 1,437 & 1,641 & 1,814 & 1,893 & 1,464 & 1,285 & 1,234 \\
\hline \multicolumn{8}{|l|}{ OECD Europe } \\
\hline 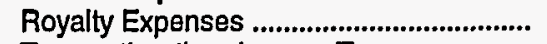 & 300 & 224 & 544 & 495 & 465 & 305 & 206 \\
\hline Taxes other than Income Taxes ................ & 153 & 100 & 270 & 229 & 257 & 214 & 274 \\
\hline 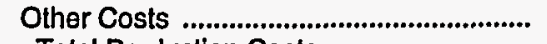 & 3,147 & 3,073 & 3,692 & 4,353 & 4,199 & 3,617 & 4,128 \\
\hline Total Production Costs .............................. & 3,600 & 3,397 & 4,506 & 5,077 & 4,921 & 4,136 & 4,608 \\
\hline \multicolumn{8}{|l|}{ Former Soviet Union and E. Europe } \\
\hline 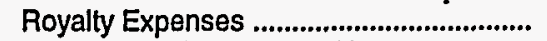 & 0 & 0 & 0 & 0 & 0 & 0 & 0 \\
\hline Taxes other than Income Taxes ................ & 0 & 0 & 0 & 0 & 0 & 0 & W \\
\hline Other Costs & 0 & 0 & 0 & 0 & 0 & 54 & W \\
\hline 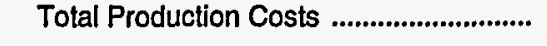 & 0 & 0 & 0 & 0 & 0 & 54 & 65 \\
\hline \multicolumn{8}{|l|}{ Afrlca } \\
\hline 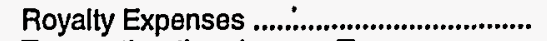 & 170 & 210 & 317 & 295 & 282 & W & W \\
\hline Taxes other than Income Taxes ................ & 31 & 14 & 9 & 14 & 21 & $W$ & W \\
\hline Other Costs & 575 & 480 & 625 & 680 & 776 & 821 & 740 \\
\hline Total Production Costs .............................. & 776 & 704 & 951 & 989 & 1,079 & 1,122 & 1,011 \\
\hline \multicolumn{8}{|l|}{ Middle East } \\
\hline 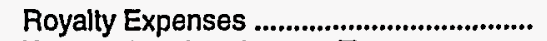 & 103 & W & W & W & 62 & $W$ & W \\
\hline Taxes other than Income Taxes ................ & 72 & $W$ & W & W & 292 & $W$ & W \\
\hline Other Costs & 273 & 295 & 305 & 217 & 324 & 313 & 340 \\
\hline Total Production Costs ................................ & 448 & 454 & 468 & 316 & 678 & 424 & 435 \\
\hline \multirow{2}{*}{\multicolumn{8}{|c|}{$\begin{array}{l}\text { Other Eastern Hemisphiere } \\
\text { Royalty Expenses and }\end{array}$}} \\
\hline & & & & & & & \\
\hline Taxes other than Income Taxes ................ & 608 & 566 & 687 & 730 & 685 & 630 & 433 \\
\hline Other Costs & 920 & 972 & 1,318 & 1,420 & 1,400 & 1,173 & 1,132 \\
\hline Total Production Costs .............................. & 1,528 & 1,538 & 2,005 & 2,150 & 2,085 & 1,803 & 1,565 \\
\hline \multicolumn{8}{|l|}{ other Western Hemisphere } \\
\hline Royalty Expenses and & & & & & & & \\
\hline Taxes other than Income Taxes ............... & 196 & 210 & 312 & 230 & 137 & 122 & 83 \\
\hline Other Costs & 387 & 482 & 530 & 481 & 450 & 374 & 346 \\
\hline 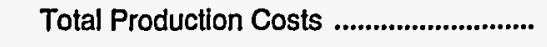 & 583 & 692 & 842 & 711 & 587 & 496 & 429 \\
\hline \multicolumn{8}{|l|}{ Total Foreign } \\
\hline 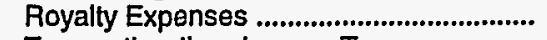 & 697 & 618 & 1,107 & 968 & 991 & 789 & 613 \\
\hline Taxes other than Income Taxes ................ & 1,050 & 978 & 1,273 & 1,220 & 1,286 & 969 & 843 \\
\hline Other Costs & 6,625 & 6,830 & 8,206 & 8,948 & 8,537 & 7,562 & 7,891 \\
\hline Total Production Costs .............................. & 8,372 & 8,426 & 10,586 & 11,136 & 10,814 & 9,320 & 9,347 \\
\hline
\end{tabular}

$W=$ Data withheld to avoid disclosure.

- = Not applicable.

Source: Energy Information Administration, Form EIA-28. 
Table B39. U.S. Refining/Marketing Dispositions of Refined Products by Channel of Distribution for FRS Companies, 1988-1994

\begin{tabular}{|c|c|c|c|c|c|c|c|}
\hline U.S. Dispositions & 1988 & 1989 & 1990 & 1991 & 1992 & 1993 & 1994 \\
\hline & \multicolumn{7}{|c|}{ Values (million dollars) } \\
\hline \multicolumn{8}{|l|}{ Motor Gasoline } \\
\hline $\begin{array}{l}\text { Intersegment Sales } \\
\text { U.S. Third-Party Sales }\end{array}$ & 194 & 244 & 247 & 568 & 231 & 196 & 268 \\
\hline $\begin{array}{l}\text { Wholesale-Resellers ............................. } \\
\text { Company Operated Automotive }\end{array}$ & 25,313 & 26,451 & 33,255 & 28,854 & 26,641 & 24,954 & 24,923 \\
\hline $\begin{array}{l}\text { Outlets ................................................ } \\
\text { Company Lessee and Open }\end{array}$ & 9,733 & 11,308 & 14,238 & 13,059 & 12,049 & 11,018 & 9,694 \\
\hline $\begin{array}{l}\text { Automotive Outlets .................................... } \\
\text { Other (Industrial, Commercial }\end{array}$ & 20,284 & 23,050 & 25,373 & 22,459 & 23,061 & 21,917 & 20,948 \\
\hline 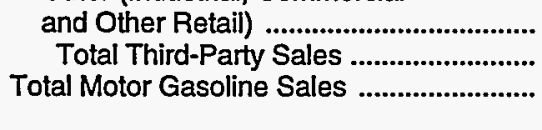 & $\begin{array}{r}5,045 \\
60,375 \\
60,569\end{array}$ & $\begin{array}{r}4,566 \\
65,375 \\
65,619\end{array}$ & $\begin{array}{r}4,576 \\
77,442 \\
77,689\end{array}$ & $\begin{array}{r}4,043 \\
68,415 \\
68,983\end{array}$ & $\begin{array}{r}5,713 \\
67,464 \\
67,695\end{array}$ & $\begin{array}{r}5,391 \\
63,280 \\
63,476\end{array}$ & $\begin{array}{r}5,199 \\
60,764 \\
61,032\end{array}$ \\
\hline \multicolumn{8}{|l|}{ Distillate Fuels } \\
\hline 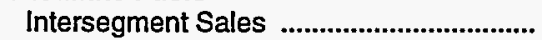 & 311 & 398 & 473 & 483 & 550 & 440 & 211 \\
\hline Third-Party Sales ........................................ & 28,218 & 32,277 & 40,222 & 35,052 & 33,370 & 32,624 & 30,357 \\
\hline Total Distillate Fuels Sales ............................ & 28,529 & 32,675 & 40,695 & 35,535 & 33,920 & 33,064 & 30,568 \\
\hline \multicolumn{8}{|l|}{ Other Refined Products } \\
\hline 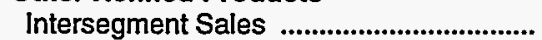 & 4,404 & 4,511 & 5,093 & 4,435 & 4,671 & 4,213 & 3,824 \\
\hline 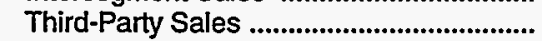 & 17,388 & 19,124 & 20,945 & 19,032 & 17,854 & 16,894 & 19,366 \\
\hline Total Other Refined Products Sales ............ & 21,792 & 23,635 & 26,038 & 23,467 & 22,525 & 21,107 & 23,190 \\
\hline \multicolumn{8}{|l|}{ Total U.S. Refined Products } \\
\hline 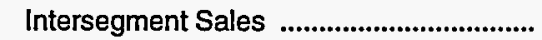 & 4,909 & 5,153 & 5,813 & 5,486 & 5,452 & 4,849 & 4,303 \\
\hline 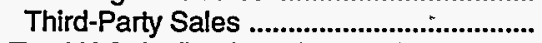 & 105,981 & 116,776 & 138,609 & 122,499 & 118,688 & 112,798 & 110,487 \\
\hline \multirow[t]{2}{*}{ Total U.S. Refined Products Sales ............... } & 110,890 & 121,929 & 144,422 & 127,985 & 124,140 & 117,647 & 114,790 \\
\hline & \multicolumn{7}{|c|}{ Volumes (million barrels) } \\
\hline \multicolumn{8}{|l|}{ Motor Gasoline } \\
\hline $\begin{array}{l}\text { Intersegment Sales .................................. } \\
\text { U.S. Third-Party Sales }\end{array}$ & 9 & 12 & 8 & 18 & 9 & 9 & 9 \\
\hline $\begin{array}{l}\text { Wholesale-Resellers .............................. } \\
\text { Company Operated Automotive }\end{array}$ & 1,107 & 1,007 & 1,072 & 996 & 972 & 1,012 & 1,064 \\
\hline $\begin{array}{l}\text { Outlets ................................................... } \\
\text { Company Lessee and Open }\end{array}$ & 340 & 356 & 384 & 367 & 350 & 342 & 308 \\
\hline $\begin{array}{l}\text { Automotive Outlets ..................................... } \\
\text { Other (Industrial, Commercial }\end{array}$ & 742 & 768 & 719 & 734 & 740 & 731 & 732 \\
\hline and Other Retail) & 262 & 184 & 163 & 151 & 216 & 233 & 233 \\
\hline Total Third-Party Sales .......................... & 2,451 & 2,314 & 2,338 & 2,248 & 2,277 & 2,318 & 2,338 \\
\hline Total Motor Gasoline Sales ........................... & 2,460 & 2,325 & 2,346 & 2,267 & 2,286 & 2,327 & 2,347 \\
\hline \multicolumn{8}{|l|}{ Distillate Fuels } \\
\hline 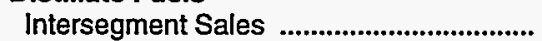 & 16 & 16 & 16 & 19 & & & 11 \\
\hline 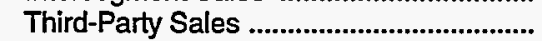 & 1,395 & 1,345 & 1,356 & 1,328 & 1,340 & 1,380 & 1,381 \\
\hline Total Distillate Fuels Sales ........................... & 1,411 & 1,361 & 1,372 & 1,347 & 1,364 & 1,400 & 1,392 \\
\hline \multicolumn{8}{|l|}{ Other Refined Products } \\
\hline 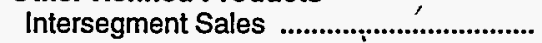 & 272 & 232 & 230 & 212 & 232 & 240 & 226 \\
\hline 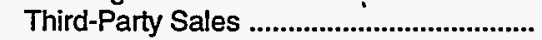 & 1,010 & 1,004 & 879 & 925 & 896 & 843 & 946 \\
\hline Total Other Refined Products Sales ........... & 1,281 & 1,236 & 1,108 & 1,137 & 1,128 & 1,082 & 1,172 \\
\hline \multicolumn{8}{|l|}{ Total U.S. Refined Products } \\
\hline Intersegment Sales & 296 & 260 & 253 & 249 & 264 & 269 & 246 \\
\hline Third-Party Sales & 4,855 & 4,663 & 4,573 & 4,502 & 4,513 & 4,541 & 4,665 \\
\hline 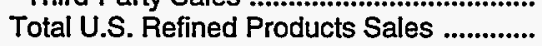 & 5,152 & 4,923 & 4,826 & 4,751 & 4,778 & 4,810 & 4,911 \\
\hline
\end{tabular}

See footnote at end of table. 
Table B39. U.S. Refining/Marketing Dispositions of Refined Products by Channel of Distribution for FRS Companies, 1988-1994 (Continued)

\begin{tabular}{|c|c|c|c|c|c|c|c|}
\hline U.S. Dispositions & 1988 & 1989 & 1990 & 1991 & 1992 & 1993 & 1994 \\
\hline & \multicolumn{7}{|c|}{ Number of Automotive Outlets } \\
\hline \multicolumn{8}{|l|}{$\begin{array}{l}\text { Number of Active Automoblle } \\
\text { Outlets at Year End }\end{array}$} \\
\hline 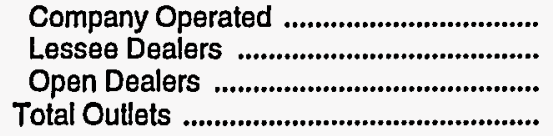 & $\begin{array}{l}10,712 \\
22,569 \\
32,919 \\
66,200\end{array}$ & $\begin{array}{l}10,995 \\
21,114 \\
21,475 \\
53,584\end{array}$ & $\begin{array}{l}11,177 \\
20,376 \\
19,532 \\
51,085\end{array}$ & $\begin{array}{l}10,745 \\
19,891 \\
17,969 \\
48,605\end{array}$ & $\begin{array}{r}9,935 \\
19,334 \\
17,297 \\
46,566\end{array}$ & $\begin{array}{r}9,021 \\
18,588 \\
16,088 \\
43,697\end{array}$ & $\begin{array}{r}8,755 \\
16,385 \\
15,320 \\
40,460\end{array}$ \\
\hline
\end{tabular}

Source: Energy Information Administration, Form ElA-28. 
Table B40. Sales of U.S. Refined Products, by Volume and Price, for FRS Companies Ranked by Total Energy Assets, 1993 and 1994

(Million Barrels and Dollars per Barrel)

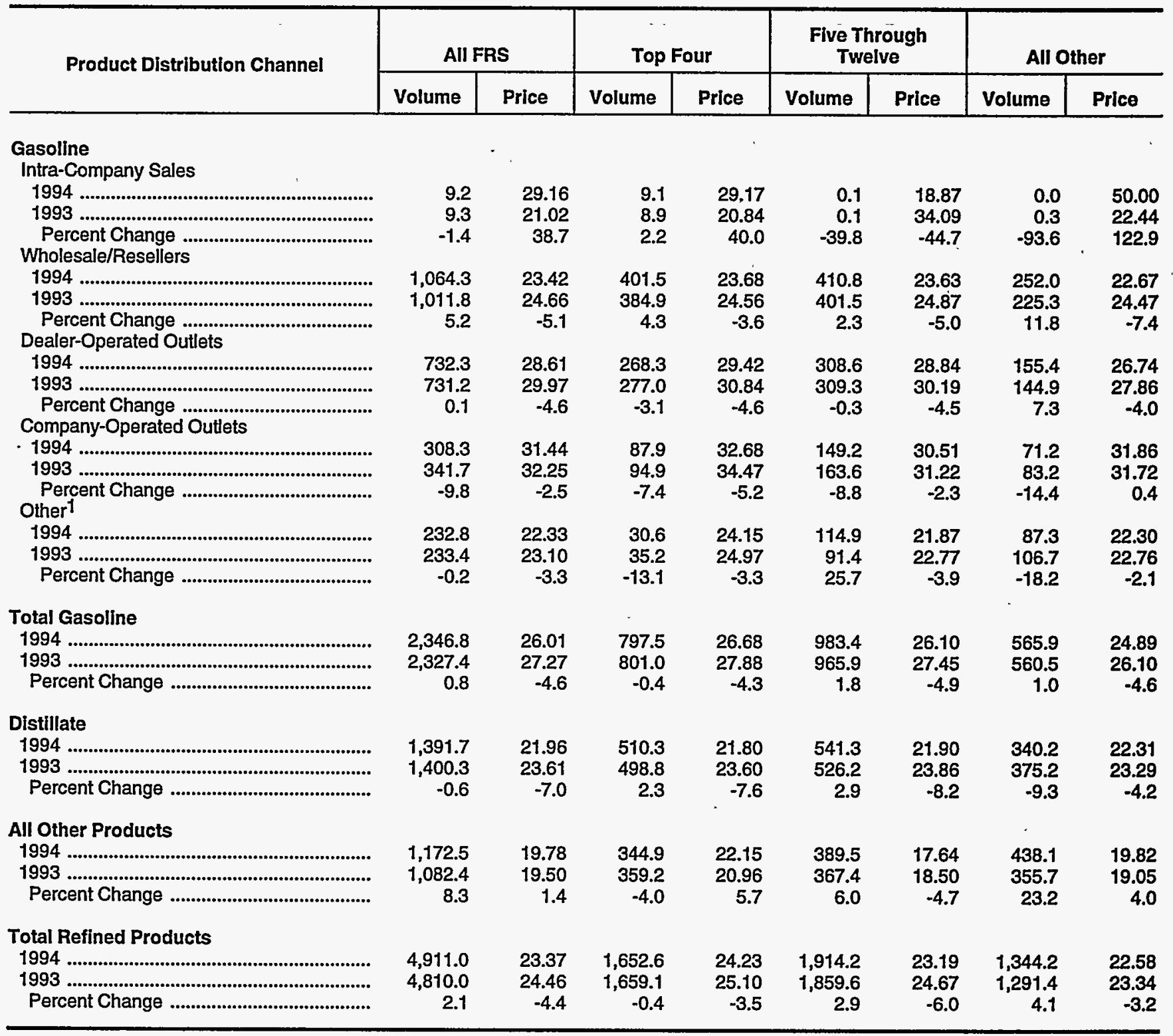

1 Includes direct sales to industrial and commercial customers and sales to unconsolidated affiliates. Note: Sum of components may not equal total due to independent rounding.

Source: Energy Information Administration, Form ElA-28. 
Table B41. U.S. Petroleum Refining/Marketing, General Operating Expenses for FRS Companies, 1988-1994 (Billion Dollars)

\begin{tabular}{|c|c|c|c|c|c|c|c|}
\hline General Operating Expenses & 1988 & 1989 & 1990 & 1991 & 1992 & 1993 & 1994 \\
\hline \multicolumn{8}{|l|}{ Raw Materlal Supply } \\
\hline Raw Material Purchases ................................ & 102.4 & 121.8 & 151.8 & 135.9 & 134.9 & 125.5 & 120.3 \\
\hline Other Raw Material Supply Expense ............ & 6.3 & 5.6 & 4.1 & 4.8 & 4.3 & 5.1 & 5.0 \\
\hline Total Raw Material Supply Expense ............... & 108.8 & 127.3 & 155.8 & 140.7 & 139.2 & 130.6 & 125.3 \\
\hline Less: Cost of Raw Materials Input & & & & & & & \\
\hline 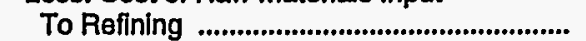 & 61.0 & 71.3 & 83.4 & 72.5 & 69.1 & 61.0 & 59.3 \\
\hline 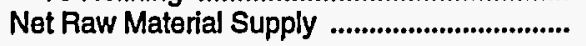 & 47.8 & 56.0 & 72.4 & 68.2 & 70.1 & 69.6 & 66.0 \\
\hline \multicolumn{8}{|l|}{ Refining } \\
\hline Raw Materials Input to Refining .................... & 61.0 & 71.3 & 83.4 & 72.5 & 69.1 & 61.0 & 59.3 \\
\hline Less: Raw Material Used as Refinery Fuel .. & 3.7 & 3.9 & 3.9 & 3.6 & 3.4 & 3.6 & 2.9 \\
\hline Refinery Process Energy Expense ............... & 5.5 & 5.2 & 5.5 & 5.5 & 5.4 & 5.6 & 4.7 \\
\hline Other Refining Operating Expenses ............. & 8.9 & 8.6 & 9.8 & 9.9 & 9.9 & 9.8 & 9.7 \\
\hline Refined Product Purchases ........................... & 20.5 & 24.4 & 31.4 & 27.0 & 27.7 & 26.9 & 27.4 \\
\hline Other Refined Product Supply Expenses .... & 4.3 & 3.3 & 4.6 & 4.1 & 3.7 & 4.2 & 3.4 \\
\hline Total Refining & 96.3 & 108.9 & 130.8 & 115.5 & 112.4 & 103.9 & 101.6 \\
\hline \multicolumn{8}{|l|}{ Marketing } \\
\hline Cost of Other Products Sold .......................... & 2.9 & 4.0 & 4.8 & 5.8 & 4.6 & 4.7 & 4.1 \\
\hline Other Marketing Expenses ................................ & 8.1 & 8.9 & 9.8 & 11.4 & 12.9 & 10.5 & 8.8 \\
\hline 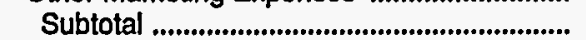 & 11.0 & 12.9 & 14.6 & 17.2 & 17.5 & 15.2 & 12.9 \\
\hline Expense of Transport Services for Others ... & 0.5 & 1.1 & 0.6 & 0.5 & 1.1 & 1.0 & 1.1 \\
\hline 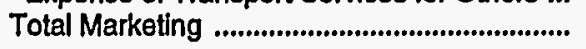 & 11.5 & 14.0 & 15.3 & 17.7 & 18.6 & 16.1 & 14.0 \\
\hline \multicolumn{8}{|l|}{ Total U.S. ReflnIng/Marketing Segment } \\
\hline General Operatjng Expenses ........................ & 155.6 & 178.9 & 218.5 & 201.4 & 201.1 & 189.7 & 181.7 \\
\hline
\end{tabular}

Source: Energy Information Administration, Form EIA-28. 
Table B42. U.S. Petroleum Segments Purchases and Sales of Raw Materials and Refined Products for FRS Companies, 1988-1994

\begin{tabular}{|c|c|c|c|c|c|c|c|}
\hline Purchases and Sales & 1988 & 1989 & 1990 & 1991 & 1992 & 1993 & 1994 \\
\hline & \multicolumn{7}{|c|}{ Values (million dollars) } \\
\hline \multicolumn{8}{|l|}{$\begin{array}{l}\text { Purchases } \\
\text { U.S. Refining/Marketing Segment } \\
\text { Raw Materials }\end{array}$} \\
\hline 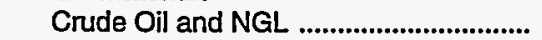 & 97,203 & 116,552 & 144,973 & 129,380 & 124,868 & 111,654 & 104,471 \\
\hline 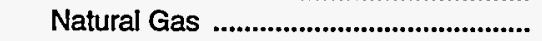 & 2,878 & 3,237 & 3,935 & 4,367 & 7,504 & 10,678 & 12,360 \\
\hline Other Raw Materials ................................. & 2,354 & 1,973 & 2,848 & 2,195 & 2,496 & 3,196 & 3,498 \\
\hline $\begin{array}{l}\text { Total Raw Materials .............................. } \\
\text { Refined Products }\end{array}$ & 102,435 & 121,762 & 151,756 & 135,942 & 134,868 & 125,528 & 120,329 \\
\hline 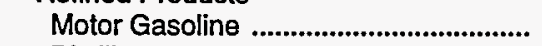 & 10,332 & 11,095 & 13,927 & 12,106 & 12,403 & 11,831 & 12,430 \\
\hline 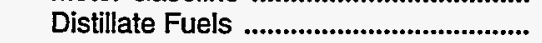 & 3,642 & 5,274 & 7,006 & 5,738 & 6,008 & 6,629 & 6,626 \\
\hline Other Refined Products ............................... & 6,489 & 8,016 & 10,497 & 9,136 & 9,261 & 8,467 & 8,389 \\
\hline 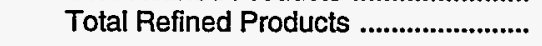 & 20,463 & 24,385 & 31,430 & 26,980 & 27,672 & 26,927 & 27,445 \\
\hline \multicolumn{8}{|l|}{ U.S. Production Segment } \\
\hline Crude Oil and NGL & 1,745 & 2,138 & 2,702 & 4,186 & 2,816 & 2,458 & 2,660 \\
\hline 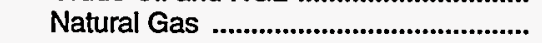 & 2,702 & 2,845 & 3,167 & 3,223 & 4,192 & 5,042 & 5,950 \\
\hline 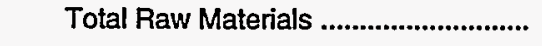 & 4,447 & 4,983 & 5,869 & 7,409 & 7,008 & 7,500 & 8,610 \\
\hline \multicolumn{8}{|l|}{ Sales } \\
\hline \multicolumn{8}{|l|}{$\begin{array}{l}\text { U.S. Refining/Marketing Segment } \\
\text { Raw Materials }\end{array}$} \\
\hline 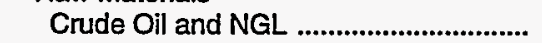 & 46,072 & 55,078 & 69,037 & 64,948 & 63,564 & 56,612 & 49,752 \\
\hline 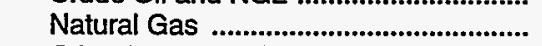 & 2,188 & 2,262 & 3,226 & 3,873 & 7,406 & 10,527 & 12,432 \\
\hline 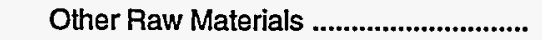 & 1,509 & 1,084 & 1,271 & 929 & 1,175 & 1,720 & 2,201 \\
\hline Total Raw Materials ................................. & 49,769 & 58,424 & 73,534 & 69,750 & 72,145 & 68,859 & 64,385 \\
\hline \multicolumn{8}{|l|}{ Refined Products } \\
\hline 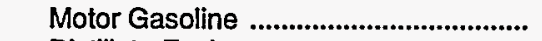 & 60,569 & 65,619 & 77,689 & 68,983 & 67,695 & 63,476 & 61,032 \\
\hline 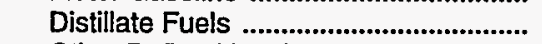 & 28,529 & 32,675 & 40,695 & 35,535 & 33,920 & 33,064 & 30,568 \\
\hline 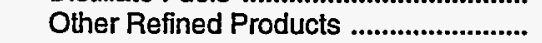 & 21,792 & 23,635 & 26,038 & 23,467 & 22,525 & 21,107 & 23,190 \\
\hline 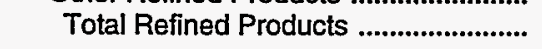 & 110,890 & 121,929 & 144,422 & 127,985 & 124,140 & 117,647 & 114,790 \\
\hline \multicolumn{8}{|l|}{ U.S. Production Segment } \\
\hline 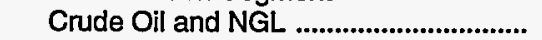 & 27,640 & 30,936 & 38,088 & 32,372 & 29,585 & 25,734 & 23,468 \\
\hline 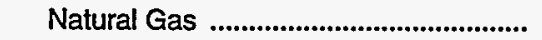 & 15,241 & 14,965 & 15,999 & 14,071 & 16,905 & 20,238 & 19,757 \\
\hline 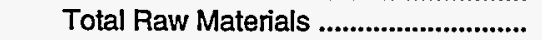 & 42,881 & 45,901 & 54,087 & 46,443 & 46,490 & 45,972 & 43,225 \\
\hline
\end{tabular}

See footnote at end of table. 
Table B42. U.S. Petroleum Segments Purchases and Sales of Raw Materials and Refined Products for FRS Companies, 1988-1994 (Continued)

\begin{tabular}{|c|c|c|c|c|c|c|c|}
\hline Purchases and Sales & 1988 & 1989 & 1990 & 1991 & 1992 & 1993 & 1994 \\
\hline & \multicolumn{7}{|c|}{ Volumes } \\
\hline \multicolumn{8}{|l|}{$\begin{array}{l}\text { Purchases } \\
\text { U.S. Refining/Marketing Segment } \\
\text { Raw Materials }\end{array}$} \\
\hline $\begin{array}{l}\text { Crude Oil and NGL (million barrels) .... } \\
\text { Natural Gas (billion cubic feet) ............. }\end{array}$ & $\begin{array}{l}7,065 \\
1,726\end{array}$ & $\begin{array}{l}7,031 \\
1,960\end{array}$ & $\begin{array}{l}6,991 \\
2,276\end{array}$ & $\begin{array}{l}6,985 \\
2,884\end{array}$ & $\begin{array}{l}7,176 \\
4,593\end{array}$ & $\begin{array}{l}7,032 \\
6,022\end{array}$ & $\begin{array}{l}7,090 \\
7,479\end{array}$ \\
\hline $\begin{array}{l}\text { Refined Products (million barrels) } \\
\text { Motor Gasoline ....................................... } \\
\text { Distillate Fuels ........................................ } \\
\text { Other Refined Products ......................... } \\
\text { Total Refined Products ....................... }\end{array}$ & $\begin{array}{r}479 \\
195 \\
383 \\
1,058\end{array}$ & $\begin{array}{r}447 \\
236 \\
442 \\
1,125\end{array}$ & $\begin{array}{r}454 \\
242 \\
399 \\
1,094\end{array}$ & $\begin{array}{r}427 \\
226 \\
407 \\
1,059\end{array}$ & $\begin{array}{r}467 \\
253 \\
410 \\
1,129\end{array}$ & $\begin{array}{r}487 \\
288 \\
378 \\
1,153\end{array}$ & $\begin{array}{r}563 \\
322 \\
345 \\
1,230\end{array}$ \\
\hline $\begin{array}{l}\text { U.S. Production Segment } \\
\text { Crude Oil and NGL (million barrels) .... } \\
\text { Natural Gas (billion cubic feet) ............ }\end{array}$ & $\begin{array}{r}166 \\
1,761\end{array}$ & $\begin{array}{r}184 \\
1,802\end{array}$ & $\begin{array}{r}177 \\
1,875\end{array}$ & $\begin{array}{r}222 \\
2,067\end{array}$ & $\begin{array}{r}206 \\
2,408\end{array}$ & $\begin{array}{r}178 \\
2,569\end{array}$ & $\begin{array}{r}201 \\
3,276\end{array}$ \\
\hline $\begin{array}{l}\text { Sales } \\
\text { U.S. Refining/Marketing Segment } \\
\text { Raw Materials }\end{array}$ & & & & & & & \\
\hline $\begin{array}{l}\text { Crude Oil and NGL (million barrels) ..... } \\
\text { Natural Gas (billion cubic feet) .............. }\end{array}$ & $\begin{array}{l}3,122 \\
1,310\end{array}$ & $\begin{array}{l}3,226 \\
1,350\end{array}$ & $\begin{array}{l}3,286 \\
1,851\end{array}$ & $\begin{array}{l}3,359 \\
2,457\end{array}$ & $\begin{array}{l}3,572 \\
4,198\end{array}$ & $\begin{array}{l}3,436 \\
5,416\end{array}$ & $\begin{array}{l}3,406 \\
6,960\end{array}$ \\
\hline 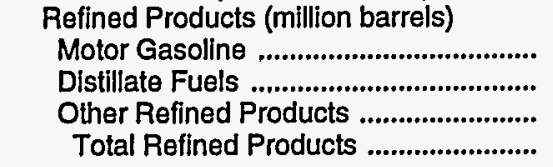 & $\begin{array}{l}2,460 \\
1,411 \\
1,281 \\
5,152\end{array}$ & $\begin{array}{l}2,325 \\
1,361 \\
1,236 \\
4,923\end{array}$ & $\begin{array}{l}2,346 \\
1,372 \\
1,108 \\
4,826\end{array}$ & $\begin{array}{l}2,267 \\
1,347 \\
1,137 \\
4,751\end{array}$ & $\begin{array}{l}2,286 \\
1,364 \\
1,128 \\
4,778\end{array}$ & $\begin{array}{l}2,327 \\
1,400 \\
1,082 \\
4,810\end{array}$ & $\begin{array}{l}2,347 \\
1,392 \\
1,172 \\
4,911\end{array}$ \\
\hline $\begin{array}{l}\text { U.S. Production Segment } \\
\text { Crude Oil and NGL (million barrels) .... } \\
\text { Natural Gas (billion cubic feet) ............ }\end{array}$ & $\begin{array}{l}2,347 \\
8,718\end{array}$ & $\begin{array}{l}2,180 \\
8,622\end{array}$ & $\begin{array}{l}2,088 \\
8,979\end{array}$ & $\begin{array}{l}2,078 \\
8,761\end{array}$ & $\begin{array}{l}2,044 \\
9,712\end{array}$ & $\begin{array}{l}1,898 \\
9,801\end{array}$ & $\begin{array}{r}1,889 \\
10,810\end{array}$ \\
\hline
\end{tabular}

Source: Energy Information Administration, Form EIA-28. 
Table B43. U.S. and Foreign Refining/Marketing Segment, Sources and Dispositions of Crude Oil and Natural Gas Liquids for FRS Companies, 1988-1994

(Million Barrels)

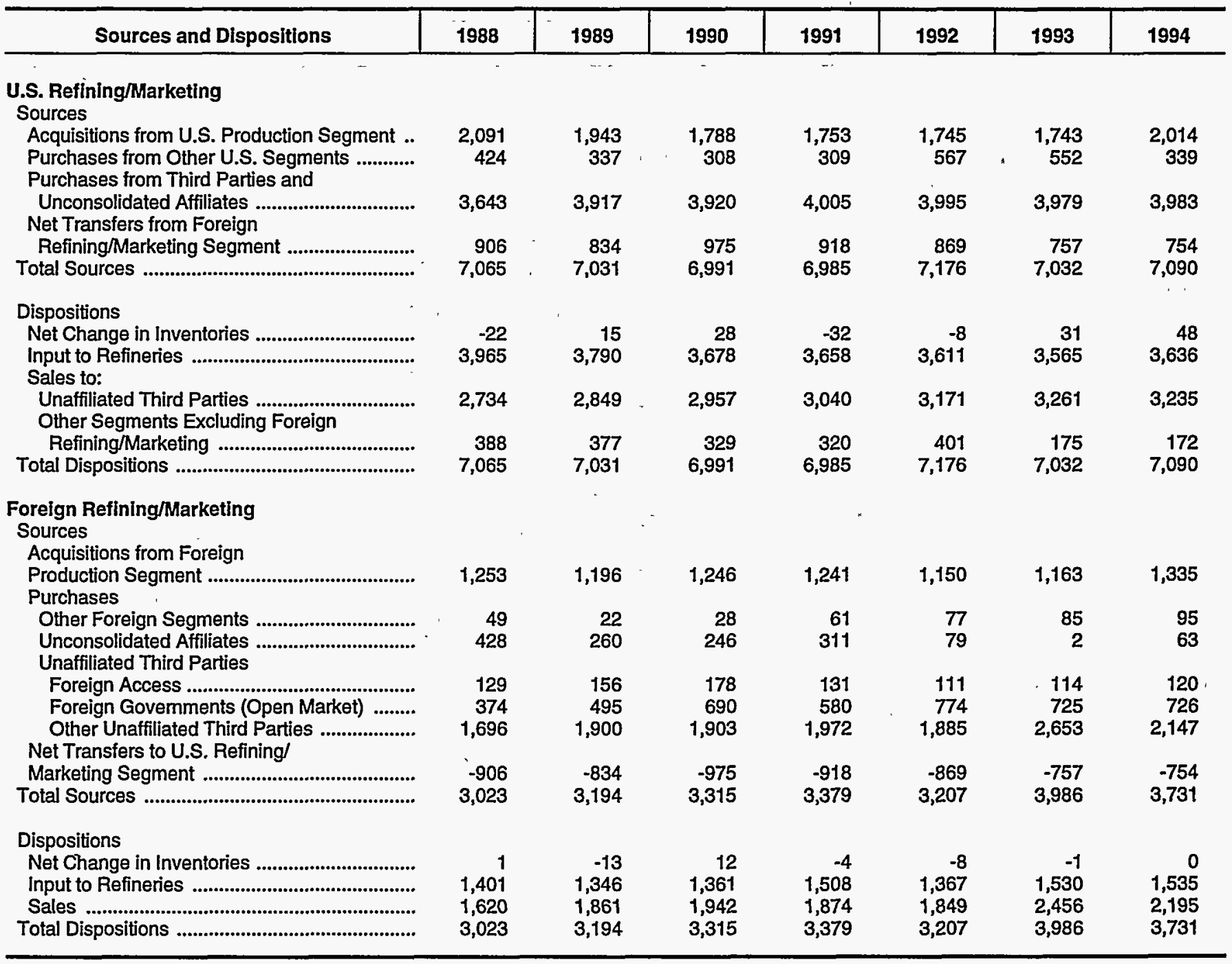

Source: Energy Information Administration, Form ElA-28. 
Table B44. U.S. and Foreign Oil Raw Materials Balance for FRS Companies Ranked by Total Energy Assets, 1992-1994

(Million Barrels)

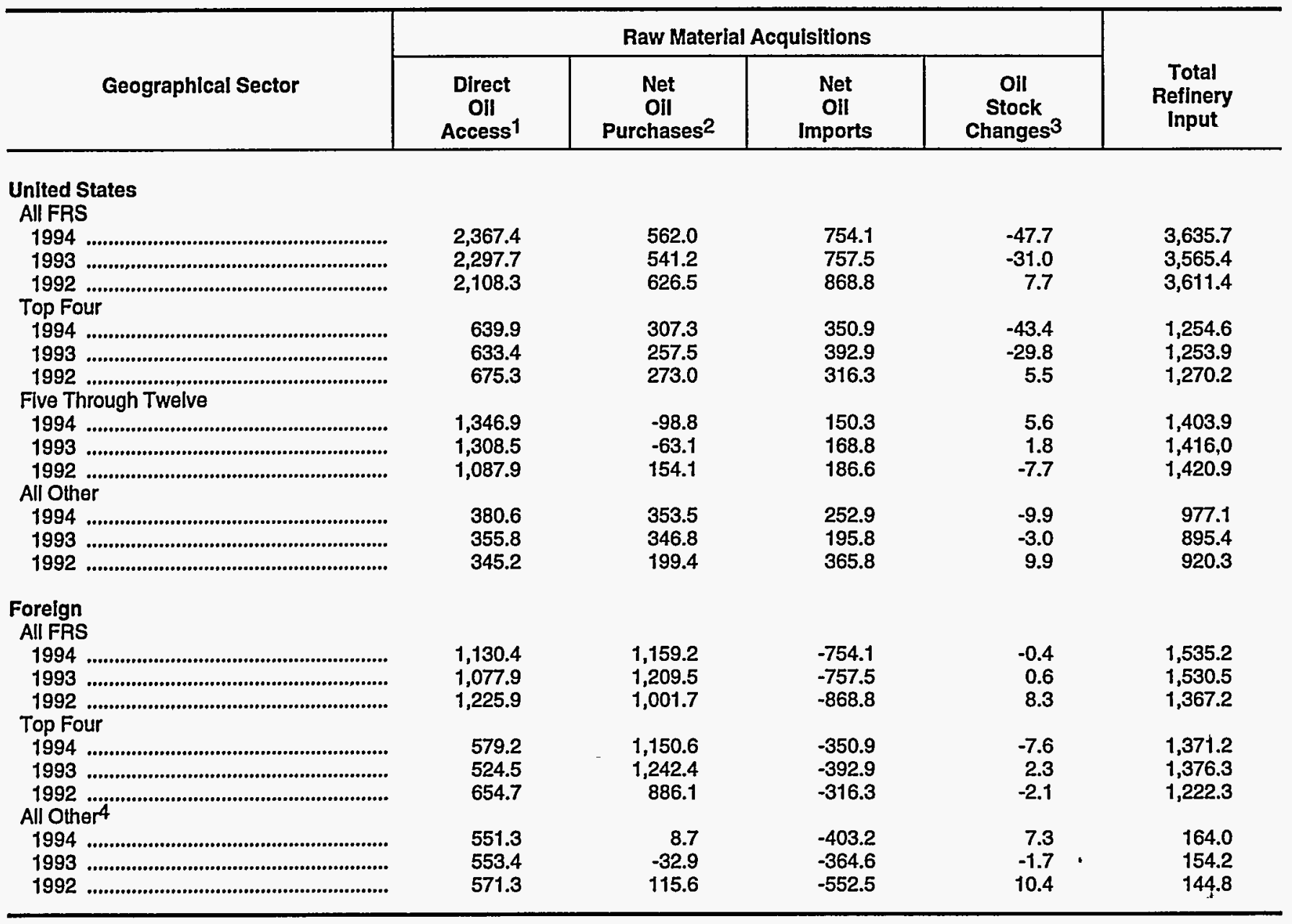

1 Ownership interest production plus purchases from other company segments and from unconsolidated affiliates of crude oil and natural gas liquids (domestic and foreign areas) plus foreign access oil (foreign area only). Foreign access represents acquisitions from foreign entities, for which reporting firms act as producers under long-term contract.

2 Purchases of crude and natural gas liquids (except imports) on the open market or from unaffiliated third parties less oil sales to unaffiliated third parties.

3 Positive number indicates stock withdrawal (addition to supply).

4 The "Five Through Twelve" and "All Other" groups combined into foreign "All Other" to prevent disclosure.

Source: Energy Information Administration, Form EIA-28. 
Table B45. U.S. Refinery Output and Refinery Capacity Statistics for FRS Companies, Ranked by Total Energy Assets, and for U.S. Industry, 1993 and 1994

(Thousand Barrels per Day)

\begin{tabular}{|c|c|c|c|c|c|c|}
\hline \multirow[b]{2}{*}{ Refined Product Statistics 1} & \multicolumn{4}{|c|}{ FRS Companies } & \multirow[b]{2}{*}{$\begin{array}{l}\text { U.S. } \\
\text { Industry }\end{array}$} & \multirow[b]{2}{*}{$\begin{array}{l}\text { FRS Percent } \\
\text { of Industry }\end{array}$} \\
\hline & $\begin{array}{c}\text { All } \\
\text { FRS }\end{array}$ & $\begin{array}{l}\text { Top } \\
\text { Four }\end{array}$ & $\begin{array}{c}\text { Five Through } \\
\text { Twelve }\end{array}$ & $\begin{array}{l}\text { All } \\
\text { Other }\end{array}$ & & \\
\hline 1994 & \multicolumn{4}{|c|}{$\therefore$} & \\
\hline Refinery Output Volume ${ }^{2}$............................ & 10,812 & 3,921 & 4,246 & 2.645 & 16,341 & 66.2 \\
\hline Percent Gasoline & 45.7 & 44.4 & 48.8 & 42.5 & 45.1 & 67.0 \\
\hline Percent Distillate & 28.0 & 27.0 & 28.2 & 29.2 & 29.5 & 62.8 \\
\hline 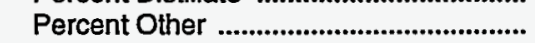 & 26.3 & 28.5 & 23.0 & 28.3 & 25.4 & 68.7 \\
\hline \multicolumn{7}{|l|}{ Refinery Capacity } \\
\hline Year's Change (Net) ................................ & -45 & -149 & -29 & 133 & 351 & -12.8 \\
\hline 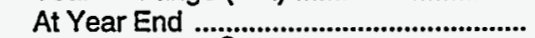 & 10,669 & 3,532 & 4,016 & 3,121 & 16,069 & 66.4 \\
\hline 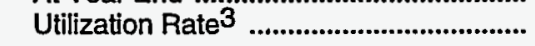 & 91.7 & 93.6 & 94.3 & 86.2 & 90.0 & $(4)$ \\
\hline \multicolumn{7}{|l|}{1993} \\
\hline Refinery Output Volume ${ }^{2}$.......................... & 10,822 & 3,985 & 4,341 & 2,496 & 16,341 & 66.2 \\
\hline 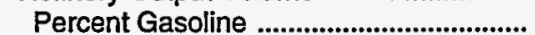 & 45.8 & 44.2 & 48.8 & 43.0 & 45.7 & 66.4 \\
\hline Percent Distillate & 26.9 & 26.0 & 27.6 & 27.3 & 28.3 & 63.1 \\
\hline Percent Other & 27.3 & 29.8 & 23.6 & 29.7 & 26.0 & 69.4 \\
\hline \multicolumn{7}{|l|}{ Refinery Capacity } \\
\hline Year's Change (Net) ................................. & -238 & -83 & -110 & -45 & -86 & 276.7 \\
\hline 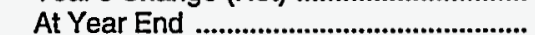 & $10, \overline{714}$ & 3,681 & 4,045 & 2,988 & 15,718 & 68.2 \\
\hline Utilization Rate 3 & 89.3 & 89.6 & 95.4 & 80.7 & 88.9 & $(4)$ \\
\hline
\end{tabular}

1 U.S. FRS and U.S. industry data include operations in Puerto Rico and the U.S. Virgin Islands.

2 For FRS companies, includes refinery output at own refineries for own account and at others' refineries for own account.

3 Defined as average daily crude runs at own refineries, for own account and for account of others, divided by average daily crude distillation capacity.

4 Not meaningful.

Note: Sum of components may not equal total due to independent rounding.

Sources: Industry data - Refinery output and refinery capacity: Energy Information Administration, Forms EIA-820 and EIA-810; see

Petroleum Supply Annuai, 1993 and 1994. FRS companies data - Energy Information Administration, Form ElA-28. 
Table B46. Foreign Refinery Output and Refinery Capacity Statistics for FRS Companies, Ranked by Total Energy Assets, and for Foreign Industry, 1993 and 1994

(Thousand Barrels per Day)

\begin{tabular}{|c|c|c|c|c|c|}
\hline \multirow[b]{2}{*}{ Refined Product Statistics 1} & \multicolumn{3}{|c|}{ FRS Companies } & \multirow[b]{2}{*}{$\begin{array}{l}\text { Foreign } \\
\text { Industry }\end{array}$} & \multirow[b]{2}{*}{$\begin{array}{c}\text { FRS Percent } \\
\text { of Industry }\end{array}$} \\
\hline & $\begin{array}{c}\text { All } \\
\text { FRS }\end{array}$ & $\begin{array}{l}\text { Top } \\
\text { Four }\end{array}$ & $\begin{array}{c}\text { All } \\
\text { Other2 }\end{array}$ & & \\
\hline \multicolumn{6}{|l|}{1994} \\
\hline Refinery Output Volume ${ }^{3}$ & 4,205 & 3,695 & 510 & - & 4) \\
\hline 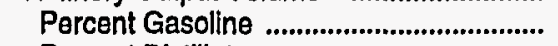 & 28.7 & 28.7 & 28.6 & - & $4\}^{\prime}$ \\
\hline Percent Distillate ......................................... & 43.1 & 42.9 & 44.7 & - & 4 ) \\
\hline 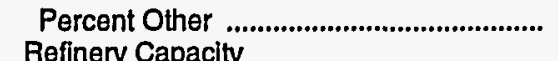 & 28.2 & 28.4 & 26.7 & - & t) \\
\hline 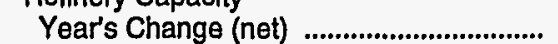 & 74 & 74 & 0 & 1,727 & 4.3 \\
\hline 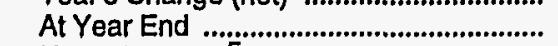 & 4,766 & 4,348 & 418 & 56,840 & 8.4 \\
\hline 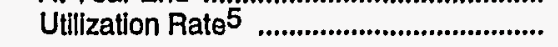 & 81.0 & 78.0 & 111.2 & - & $(4)$ \\
\hline \multicolumn{6}{|l|}{1993} \\
\hline Refinery Output Volume ${ }^{3}$............................. & 4,205 & 3,705 & 500 & - & - \\
\hline 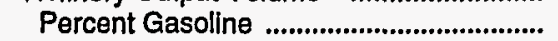 & 28.5 & 28.2 & 30.8 & - & - \\
\hline 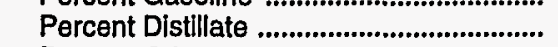 & 42.1 & 41.8 & 44.4 & - & - \\
\hline \multirow{2}{*}{\multicolumn{6}{|c|}{ Refinery Capacity }} \\
\hline & & & & & \\
\hline 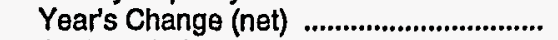 & 44 & 19 & 25 & -117 & -37.6 \\
\hline 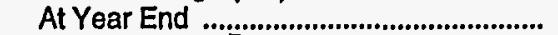 & 4,692 & 4,274 & 418 & 55,113 & 8.5 \\
\hline 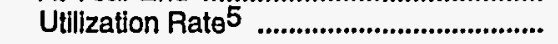 & 81.9 & 78.9 & 112.9 & - & 4 \\
\hline
\end{tabular}

1 Foreign FRS and foreign industry data exclude operations in Puerto Rico and the U.S. Virgin Islands, as well as China.

2 "Five through Twelve" and "All Other" groups combined to avoid disclosure.

3 For FRS companies, includes refinery output at own refineries for own account and at others' refineries for own account.

4 Not meaningful.

5 Defined as average daily crude runs at own refineries, for own account and for account of others, divided by average daily crude distillation capacity.

$=$ Not available.

Note: Sum of components may not equal total due to independent rounding.

Sources: Industry data - Energy Information Administration, Intemational Energy Annual, 1993 and 1994. FRS companies data - Energy Information Administration, Form EIA-28. 
Table B47. U.S. and Foreign Petroleum Refining Statistics for FRS Companies, 1988-1994

\begin{tabular}{|c|c|c|c|c|c|c|c|}
\hline Refining Statistics & 1988 & 1989 & 1990 & 1991 & 1992 & 1993 & 1994 \\
\hline & \multicolumn{7}{|c|}{ (thousand barrels per calendar day) } \\
\hline 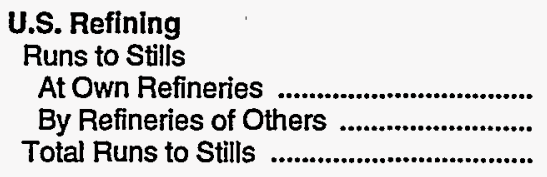 & $\begin{array}{r}10,646 \\
11 \\
10,657\end{array}$ & $\begin{array}{r}10,147 \\
4 \\
10,151\end{array}$ & $\begin{array}{r}9,922 \\
4 \\
9,926\end{array}$ & $\begin{array}{r}9,847 \\
5 \\
9,852\end{array}$ & $\begin{array}{r}9,736 \\
5 \\
9,741\end{array}$ & $\begin{array}{r}9,676 \\
5 \\
. \quad 9,681\end{array}$ & $\begin{array}{r}9,809 \\
5 \\
9,814\end{array}$ \\
\hline 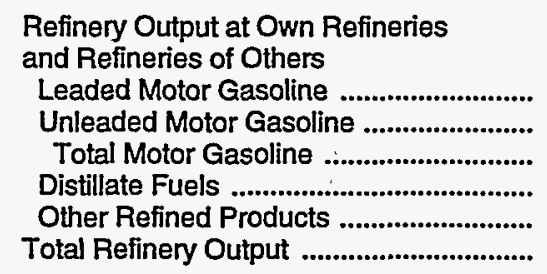 & $\begin{array}{r}936 \\
4,424 \\
5,360 \\
3,020 \\
3,653 \\
12,033\end{array}$ & $\begin{array}{r}523 \\
4,579 \\
5,102 \\
2,827 \\
3,484 \\
11,413\end{array}$ & $\begin{array}{r}256 \\
4,754 \\
5,010 \\
2,866 \\
3,436 \\
11,312\end{array}$ & $\begin{array}{r}378 \\
4,677 \\
5,055 \\
2,954 \\
3,113 \\
11,122\end{array}$ & $\begin{array}{r}251 \\
4,717 \\
4,968 \\
2,931 \\
3,095 \\
10,994\end{array}$ & $\begin{array}{r}56 \\
4,897 \\
4,953 \\
2,916 \\
2,953 \\
10,822\end{array}$ & $\begin{array}{r}41 \\
4,895 \\
4,936 \\
3,030 \\
2,846 \\
10,812\end{array}$ \\
\hline \multirow[t]{2}{*}{ Refinery Capacity at End of Year ............. } & 12,281 & 11,489 & 11,372 & 11,203 & 10,952 & 10,714 & 10,669 \\
\hline & \multicolumn{7}{|c|}{ (number of refineries) } \\
\hline \multirow[t]{2}{*}{ Number of Wholly Owned Retineries .... } & 91 & 89 & 89 & 88 & 82 & 75 & 74 \\
\hline & \multicolumn{7}{|c|}{ (thousand barrels per calendar day) } \\
\hline 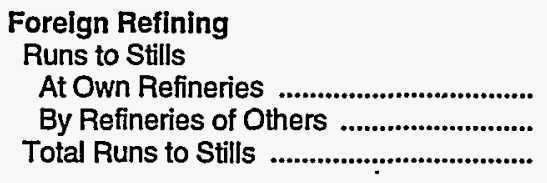 & $\begin{array}{r}3,565 \\
836 \\
4,401\end{array}$ & $\begin{array}{r}3,492 \\
685 \\
4,177\end{array}$ & $\begin{array}{r}3,575 \\
717 \\
4,292\end{array}$ & $\begin{array}{r}3,667 \\
632 \\
4,299\end{array}$ & $\begin{array}{r}3,706 \\
749 \\
4,455\end{array}$ & $\begin{array}{r}3,823 \\
312 \\
4,135\end{array}$ & $\begin{array}{r}3,829 \\
304 \\
4,133\end{array}$ \\
\hline 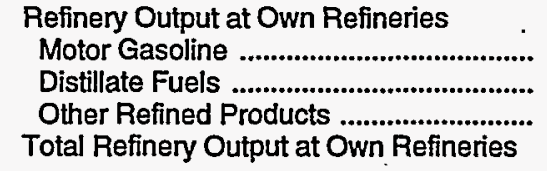 & $\begin{array}{l}1,078 \\
1,496 \\
1,262 \\
3,836\end{array}$ & $\begin{array}{l}1,044 \\
1,459 \\
1,196 \\
3,699\end{array}$ & $\begin{array}{l}1,084 \\
1,431 \\
1,075 \\
3,590\end{array}$ & $\begin{array}{l}1,097 \\
1,534 \\
1,009 \\
3,640\end{array}$ & $\begin{array}{l}1,098 \\
1,553 \\
1,064 \\
3,715\end{array}$ & $\begin{array}{l}1,114 \\
1,634 \\
1,148 \\
3,896\end{array}$ & $\begin{array}{l}1,122 \\
1,674 \\
1,102 \\
3,898\end{array}$ \\
\hline 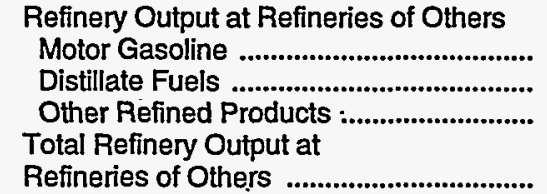 & $\begin{array}{l}270 \\
335 \\
250 \\
\\
855\end{array}$ & $\begin{array}{l}218 \\
305 \\
206\end{array}$ & $\begin{array}{l}208 \\
315 \\
199\end{array}$ & $\begin{array}{l}188 \\
303 \\
199\end{array}$ & $\begin{array}{l}199 \\
359 \\
192 \\
\\
750\end{array}$ & $\begin{array}{r}85 \\
136 \\
88\end{array}$ & $\begin{array}{r}85 \\
140 \\
82 \\
307\end{array}$ \\
\hline 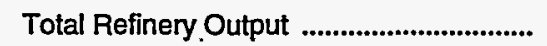 & 4,691 & 4,428 & 4,312 & 4,330 & 4,465 & 4,205 & 4,205 \\
\hline Refinery Capacity at End of Year ............. & 4,508 & 4,414 & 4,504 & 4,622 & 4,648 & 4,692 & 4,766 \\
\hline & \multicolumn{7}{|c|}{ (number of refineries) } \\
\hline Number of Wholly Owned Refineries .... & 31 & 28 & 25 & 27 & 27 & 26 & 26 \\
\hline Number of Partially Owned Refineries .. & 16 & 18 & 17 & 15 & 14 & 14 & 14 \\
\hline
\end{tabular}

Source: Energy Information Administration, Form EIA-28. 
Table B48. U.S. Refining/Marketing Revenues and Costs for FRS Companies, 1992-1994

\begin{tabular}{|c|c|c|c|c|c|c|}
\hline \multirow{2}{*}{ Revenues and Costs } & \multicolumn{3}{|c|}{ Million Dollars } & \multicolumn{3}{|c|}{ Percent of Product Revenues } \\
\hline & 1992 & 1993 & 1994 & 1992 & 1993 & 1994 \\
\hline Refined Product Revenues ........................ & $124,140.0$ & $117,647.0$ & $114,790.0$ & 100.0 & 100.0 & 100.0 \\
\hline 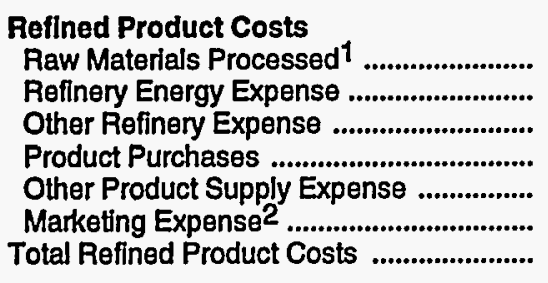 & $\begin{array}{r}63,629.0 \\
5,363.0 \\
9,040.0 \\
27,672.0 \\
3,739.0 \\
12,895.0 \\
122,338.0\end{array}$ & $\begin{array}{r}58,161.0 \\
5,636.0 \\
8,889.0 \\
26,927.0 \\
4,153.0 \\
10,463.0 \\
114,229.0\end{array}$ & $\begin{array}{r}58,025.0 \\
4,702.0 \\
8,854.0 \\
27,445.0 \\
3,432.0 \\
8,822.0 \\
111,280.0\end{array}$ & $\begin{array}{r}51.3 \\
4.3 \\
7.3 \\
22.3 \\
3.0 \\
10.4 \\
98.5\end{array}$ & $\begin{array}{r}49.4 \\
4.8 \\
7.6 \\
22.9 \\
3.5 \\
8.9 \\
97.1\end{array}$ & $\begin{array}{r}50.5 \\
4.1 \\
7.7 \\
23.9 \\
3.0 \\
7.7 \\
96.9\end{array}$ \\
\hline $\begin{array}{l}\text { Reflned Product Margin ............................ } \\
\text { Dollars per Barrel Margin } 3 . . . . . . . . . . . . . . .\end{array}$ & $\begin{array}{r}1,802.0 \\
0.38\end{array}$ & $\begin{array}{r}3,418.0 \\
0.71\end{array}$ & $\begin{array}{r}3,510.0 \\
0.71\end{array}$ & 1.5 & $\begin{array}{l}2.9 \\
--\end{array}$ & 3.1 \\
\hline Other Reflning/Marketing Revenues 4 ... & $10,007.0$ & $10,614.0$ & $10,586.0$ & - & - & - \\
\hline 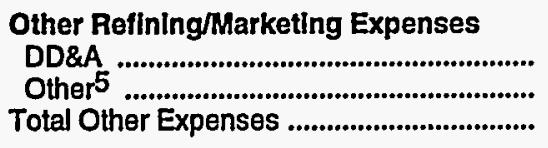 & $\begin{array}{r}3,532.0 \\
8,151.0 \\
11,683.0\end{array}$ & $\begin{array}{r}3,659.0 \\
7,796.0 \\
11,455.0\end{array}$ & $\begin{array}{r}3,780.0 \\
7,454.0 \\
11,234.0\end{array}$ & $\overline{-}$ & $\overline{-}$ & $\begin{array}{l}- \\
-\end{array}$ \\
\hline Reflning/Marketing Operating Income .. & 126.0 & $2,577.0$ & $2,862.0$ & - & - & - \\
\hline Mlscellaneous Revenue \& Expense 6 .... & -115.0 & 207.0 & 289.0 & - & - & - \\
\hline Less Income Taxes ....................................... & 217.0 & $1,099.0$ & $1,306.0$ & - & -- & - \\
\hline Refining/Marketing Net Income ................ & -213.0 & $1,685.0$ & $1,845.0$ & - & - & - \\
\hline
\end{tabular}

1 Represents reported cost of raw materials processed at refineries, less any profit from raw material trades or exchanges by refining/marketing.

2 Excludes cost of marketing tires, batteries, and accessories (TBA).

3 Dollars per barrel of refined product sold.

4 includes revenues from transportation services supplied (non-federally regulated), TBA sales and miscellaneous.

5 Includes general and administrative expenses, research and development costs, costs of transportation services supplied to others not included in raw material costs, and expenses for TBA.

6 Includes other revenue and expense items, extraordinary items, and cumulative effect of accounting changes.

- = Not applicable.

Source: Energy Information Administration, Form EIA-28. 
Table B49. Sources of U.S. Bituminous Coal and Lignite Production, by Region and Mining Method, for FRS Companies and U.S. Industry, 1994, and Percent Change From 1993

\begin{tabular}{|c|c|c|c|c|c|c|}
\hline \multirow{2}{*}{ Production } & \multirow[b]{2}{*}{ Total } & \multicolumn{3}{|c|}{ Region } & \multicolumn{2}{|c|}{ Mining Method } \\
\hline & & East & Midwest & West & Underground & Surface \\
\hline & \multicolumn{6}{|c|}{ (million tons) } \\
\hline \multirow[t]{2}{*}{ 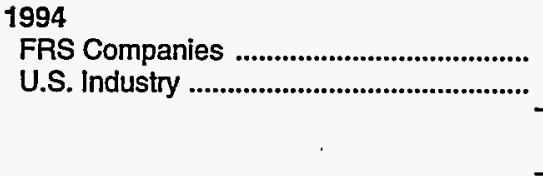 } & $\begin{array}{r}179.7 \\
1,033.5\end{array}$ & $\begin{array}{r}46.2 \\
445.4\end{array}$ & $\begin{array}{r}15.9 \\
120.9\end{array}$ & $\begin{array}{l}117.7 \\
467.2\end{array}$ & $\begin{array}{r}58.5 \\
399.1\end{array}$ & $\begin{array}{l}121.2 \\
634.4\end{array}$ \\
\hline & \multicolumn{6}{|c|}{ (percent) } \\
\hline \multicolumn{7}{|l|}{ Distribution by Region, 1994} \\
\hline $\begin{array}{l}\text { FRS Companies } \\
\text { U.S. Industry }\end{array}$ & $\begin{array}{l}100.0 \\
100.0\end{array}$ & $\begin{array}{l}25.7 \\
43.1\end{array}$ & $\begin{array}{r}8.8 \\
11.7\end{array}$ & $\begin{array}{l}65.5 \\
45.2\end{array}$ & $\ddot{-}$ & - \\
\hline \multicolumn{7}{|l|}{ Distribution by Mining Method, 1994} \\
\hline FRS Companies & $\begin{array}{l}100.0 \\
100.0\end{array}$ & - & - & -- & $\begin{array}{l}32.6 \\
38.6\end{array}$ & $\begin{array}{l}67.4 \\
61.4\end{array}$ \\
\hline $\begin{array}{l}\text { FRS Companies as a Percent } \\
\text { of U.S. Industry }\end{array}$ & 17.4 & 10.4 & 13.1 & 25.2 & 14.7 & 19.1 \\
\hline \multicolumn{7}{|l|}{ Change from 1993} \\
\hline $\begin{array}{l}\text { FRS Companies } \\
\text { U.S. Industry Total }\end{array}$ & $\begin{array}{r}-8.9 \\
9.3\end{array}$ & $\begin{array}{r}13.4 \\
8.7\end{array}$ & $\begin{array}{l}17.1 \\
13.5\end{array}$ & $\begin{array}{r}-17.7 \\
8.8\end{array}$ & $\begin{array}{l}10.9 \\
13.7\end{array}$ & $\begin{array}{r}-16.1 \\
6.7\end{array}$ \\
\hline
\end{tabular}

-- Not applicable.

Sources: Industry data - Energy Information Administration Form ElA-7A, see Coal Industry Annual 1994 (October 1995). FRS companies data - Energy Information Administration, Form EIA-28. 
Table B50. U.S. Coal Reserves Balance for FRS Companies, 1988-1994

(Million Tons)

\begin{tabular}{|c|c|c|c|c|c|c|c|}
\hline Reserves Balance & 1988 & 1989 & 1990 & 1991 & 1992 & 1993 & 1994 \\
\hline \multicolumn{8}{|l|}{ Changes to U.S. Coal Reserves } \\
\hline $\begin{array}{l}\text { Beginning of Period ........................................ } \\
\text { Changes due to: }\end{array}$ & 54,595 & 51,710 & 49,200 & 44,949 & 39,026 & 18,593 & 16,142 \\
\hline Leases/Purchases of Minerals-in-Place & 521 & 417 & 654 & -107 & 571 & 145 & $w$ \\
\hline Corporate Mergers and Acquisitions ..... & $W$ & $W$ & W & $W$ & W & 0 & W \\
\hline Other Reserve Changes ............................. & w & w & W & W & W & -325 & -61 \\
\hline Production .................................................... & -285 & -287 & -282 & -290 & -252 & -197 & -180 \\
\hline Dispositions of Minerals-in-Place ........... & -653 & -793 & $-4,002$ & $-7,824$ & $-18,576$ & $-2,074$ & $-2,591$ \\
\hline 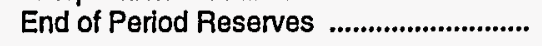 & 53,067 & 49,200 & 44,948 & 38,219 & 20,787 & 16,142 & 13,381 \\
\hline \multicolumn{8}{|l|}{ Weighted Average Annual } \\
\hline Production Capacity ..................................... & 313 & 322 & 320 & 327 & 291 & 236 & 201 \\
\hline
\end{tabular}

$W=$ Data withheld to avoid disclosure.

Source: Energy Information Administration, Form EIA-28. 
Table B51. U.S. Coal Reserves (End of Year) and Production Statistics for FRS Companies, 1988-1994 (Million Tons)

\begin{tabular}{|c|c|c|c|c|c|c|}
\hline \multirow{2}{*}{ Reserves and Production Statistics } & \multirow{2}{*}{$\begin{array}{l}\text { U.S. } \\
\text { Total }\end{array}$} & \multicolumn{3}{|c|}{ Region } & \multicolumn{2}{|c|}{ Mining Method } \\
\hline & & East & Midwest & West & Underground & Surface \\
\hline 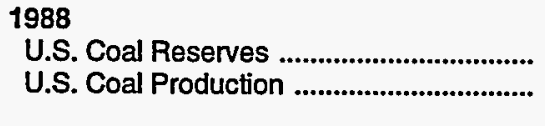 & $\begin{array}{r}53,067.2 \\
285.3\end{array}$ & $\begin{array}{r}12,656.0 \\
108.5\end{array}$ & $\begin{array}{r}7,256.2 \\
38.8\end{array}$ & $\begin{array}{r}33,154.9 \\
138.0\end{array}$ & $\begin{array}{r}16,287.1 \\
124.8\end{array}$ & $\begin{array}{r}36,780.1 \\
160.5\end{array}$ \\
\hline 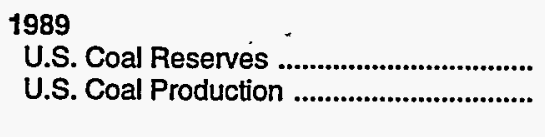 & $\begin{array}{r}49,200.2 \\
286.9\end{array}$ & $\begin{array}{r}11,462.1 \\
114.0\end{array}$ & $\begin{array}{r}7,324.2 \\
37.7\end{array}$ & $\begin{array}{r}30,413.9 \\
135.1\end{array}$ & $\begin{array}{r}15,783.7 \\
123.9\end{array}$ & $\begin{array}{r}33,416.4 \\
163.0\end{array}$ \\
\hline 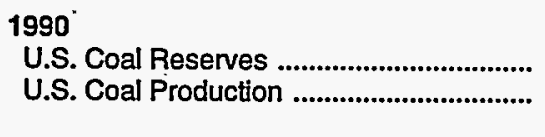 & $\begin{array}{r}44,948.5 \\
282.0\end{array}$ & $\begin{array}{r}8,864.7 \\
118.8\end{array}$ & $\begin{array}{r}6,812.0 \\
25.5\end{array}$ & $\begin{array}{r}29,271.9 \\
137.8\end{array}$ & $\begin{array}{r}14,865.6 \\
119.4\end{array}$ & $\begin{array}{r}30,082.9 \\
162.7\end{array}$ \\
\hline $\begin{array}{l}1991 \\
\text { U.S. Coal Reserves ..................................... } \\
\text { U.S. Coal Production ................................ }\end{array}$ & $\begin{array}{r}38,218.9 \\
289.6\end{array}$ & $\begin{array}{r}4,802.1 \\
114.1\end{array}$ & $\begin{array}{r}5,653.1 \\
26.2\end{array}$ & $\begin{array}{r}27,763.7 \\
149.4\end{array}$ & $\begin{array}{r}10,136.4 \\
122.8\end{array}$ & $\begin{array}{r}28,082.5 \\
166.8\end{array}$ \\
\hline $\begin{array}{l}1992 \\
\text { U.S. Coal Reserves ..................................... } \\
\text { U.S. Coal Production ................................. }\end{array}$ & $\begin{array}{r}20,787.2 \\
251.9\end{array}$ & $\begin{array}{r}4,190.0 \\
75.4\end{array}$ & $\begin{array}{r}4,733.3 \\
22.8\end{array}$ & $\begin{array}{r}11,863.9 \\
153.7\end{array}$ & $\begin{array}{r}8,127.0 \\
83.8\end{array}$ & $\begin{array}{r}12,660.3 \\
168.1\end{array}$ \\
\hline $\begin{array}{l}1993 \\
\text { U.S. Coal Reserves ...................................... } \\
\text { U.S. Coal Production ................................. }\end{array}$ & $\begin{array}{r}16,142.0 \\
197.3\end{array}$ & $\begin{array}{r}2,946.0 \\
40.7\end{array}$ & $\begin{array}{r}3,673.4 \\
13.5\end{array}$ & $\begin{array}{r}9,522.6 \\
143.0\end{array}$ & $\begin{array}{r}6,068.1 \\
52.8\end{array}$ & $\begin{array}{r}10,074.0 \\
144.5\end{array}$ \\
\hline 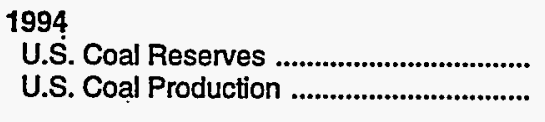 & $\begin{array}{r}13,381.3 \\
179.7\end{array}$ & $\begin{array}{r}2,833.2 \\
46.2\end{array}$ & $\begin{array}{r}3,212.5 \\
15.9\end{array}$ & $\begin{array}{r}7,335.7 \\
117.7\end{array}$ & $\begin{array}{r}5,479.1 \\
58.5\end{array}$ & $\begin{array}{r}7,902.2 \\
121.2\end{array}$ \\
\hline
\end{tabular}

Source: Energy Information Administration, Form EIA-28. 
Table B52. Research and Development Expenditures for FRS Companies, 1988-1994 (Million Dollars)

\begin{tabular}{|c|c|c|c|c|c|c|c|}
\hline $\begin{array}{c}\text { Research and Development } \\
\text { Expenditures }\end{array}$ & 1988 & 1989 & 1990 & 1991 & 1992 & 1993 & 1994 \\
\hline \multicolumn{8}{|l|}{ Sources of R\&D Funds } \\
\hline 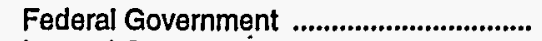 & 14 & 11 & 11 & 14 & 22 & & \\
\hline Internal Company & 3,667 & 3,664 & 3,843 & 3,832 & 3,603 & 3,308 & 2,985 \\
\hline 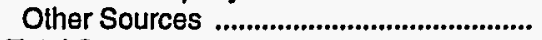 & & 28 & 49 & 56 & 60 & 26 & 50 \\
\hline 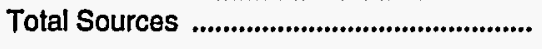 & 3,699 & 3,703 & 3,903 & 3,902 & 3,685 & 3,350 & 3,050 \\
\hline \multicolumn{8}{|l|}{ Breakdown of R\&D Expenditures } \\
\hline 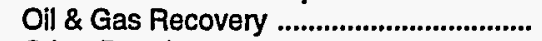 & 726 & 694 & 727 & 794 & 781 & 671 & 572 \\
\hline 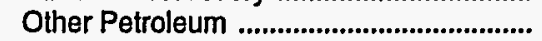 & 496 & 575 & 615 & 678 & 652 & 569 & 531 \\
\hline Coal Gasification/Liquefaction ................... & 34 & $w$ & 38 & 39 & W & $W$ & $W$ \\
\hline Other Coal & 18 & $w$ & 15 & 17 & w & $\mathbf{w}$ & $\mathbf{w}$ \\
\hline Nuclear and Other Energy ........................... & 85 & 93 & 116 & 95 & 80 & 121 & 116 \\
\hline 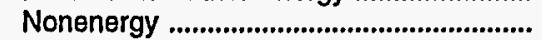 & 2,307 & 2,148 & 2,274 & 2,159 & 2,041 & 1,902 & 1,741 \\
\hline 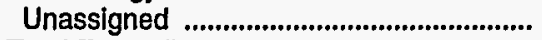 & 33 & 142 & 118 & 120 & 117 & 77 & 71 \\
\hline Total Expenditures ........................................... & 3,699 & 3,703 & 3,903 & 3,902 & 3,685 & 3,350 & 3,050 \\
\hline
\end{tabular}

W = Data withheld to avoid disclosure.

Source: Energy Information Administration, Form EIA-28. 



\section{Glossary}

Acquisition Costs: Direct costs and indirect costs incurred to acquire legal rights to wasting natural resources. Direct costs include costs incurred to obtain options to lease or purchase mineral rights and costs incurred for the actual leasing (e.g., lease bonuses) or purchasing of the rights. Indirect costs include such costs as: brokers' commissions and expenses; abstract and recording fees; filing and patenting fees; and costs of legal examination of title and documents.

Acreage: An area, measured in acres, that is subject to ownership or control by those holding total or fractional shares of working interests. Acreage is considered developed when development has been completed. (See definition for Working Interest.) A distinction may be made between "gross" acreage and "net" acreage:

- Gross. All acreage covered by any working interest, regardless of the percentage of ownership in the interest.

- Net. Gross acreage adjusted to reflect the percentage of ownership in the working interest in the acreage.

Affiliate: An "affiliate" of, or a person "affiliated" with, a specific person is a person that directly, or indirectly through one or more intermediaries, controls, or is controlled by, or is under common control with, the person specified. The term "affiliate" includes any subsidiary or parent of the person specified.

Amortization: The depreciation, depletion, or charge-off to expense of intangible and tangible assets over a period of time. In the extractive industries, the term is most frequently applied to mean either (1) the periodic charge-off to expense of the costs associated with nonproducing mineral properties incurred prior to the time when they are developed and entered into production or (2) the systematic charge-off to expense of those costs of productive mineral properties (including tangible and intangible costs of prospecting, acquisition, exploration, and development) that had been initially capitalized (or deferred) prior to the time the properties entered into production, and thereafter are charged off as minerals are produced.

Branded Product: A refined petroleum product sold by a refiner with the understanding that the purchaser has the right to resell the product under a trademark, trade name, service mark, or other identifying symbol or names owned by such refiner.

Christmas Tree: The valves and fittings installed at the top of a gas or oil well to control and direct the flow of well fluids.

Coal Gasification: The process of converting coal into gas. The basic process involves crushing coal to a powder, which is then heated in the presence of steam and oxygen to produce a gas. The gas is then refined to reduce sulfur and other impurities. The gas can be used as a fuel or processed further and concentrated into chemical or liquid fuel.

Coal Liquefaction: A chemical process that converts coal into clean-burning liquid hydrocarbons, such as synthetic crude oil and methanol.

Coal Regions: The following regional definitions are used to report domestic coal reserves, production, and other operating statistics.

- Eastern Region. Consists of the Northern Appalachian Coal Basin. The following States comprise the Eastern Region: Alabama, Georgia, Ohio, Maryland, Mississippi, Pennsylvania, Virginia, Tennessee, North Carolina, West Virginia, and Eastern Kentucky.

- Midwest Region. Consists of the Illinois and Michigan Coal Basins. The following States comprise the Midwest Region: Illinois, Indiana, Michigan, and Western Kentucky.

- Western Region. Consists of the Northern Rocky, Southern Rocky, Western Interior, and West Coast Coal Basins. The following States comprise the Central Western Region: Alaska, Arizona, Arkansas, California, Colorado, Idaho, Iowa, Kansas, Louisiana, Missouri, Montana, New Mexico, North Dakota, Oklahoma, Oregon, Texas, South Dakota, Utah, Washington, and Wyoming.

Company Automotive (Retail) Outlet: Any retail outlet selling motor fuel under a reporting company brand name. (See definition for Branded Product.) 
- Company Operated. A company retail outlet which is operated by salaried or commission personnel paid by the reporting company.

- Lessee. An independent marketer who leases the station and land and has use of tanks, pumps, signs, etc. A lessee dealer typically has a supply agreement with a refiner or a distributor and purchases products at dealer tank wagon prices. The term "lessee dealer" is limited to those dealers who are supplied directly by a refiner or any affiliate or. subsidiary company of a refiner. "Direct supply" includes use of commission agent or common carrier delivery.

- Open. An independent marketer who owns or leases (from a third party who is not a refiner) the station or land of a retail outlet and has use of tanks, pumps, signs, etc. An open dealer typically has a supply agreement with a refiner or a distributor and purchases products at or below dealer tank wagon prices.

Contribution to Net Income: The FRS segment equivalent of net income. However, many consolidated items of revenue and expense are not allocated to the segments, and therefore they are not equivalent in a strict sense. The largest item not allocated to the segments is interest expense since this is regarded as a corporatelevel item for FRS purposes.

Crude Oil: A mixture of hydrocarbons that exists in liquid phase in natural underground reservoirs and remains liquid at atmospheric pressure after passing through surface separating facilities. For FRS reporting, volumes reported as crude include:

- Liquids technically defined as crude oil.

- Small amounts of hydrocarbons that exist in the gaseous phase in natural underground reservoirs but are liquid at atmospheric pressure after being recovered from oil well (casinghead) gas in lease separators and are commingled with the crude stream without being separately measured.

- Small amounts of nonhydrocarbons produced with the oil.

Statistical data pertaining to crude oil production and reserves are reported as liquid equivalents at the surface (excluding base sediment and water) measured in terms of stock tank barrels of 42 U.S. gallons at atmospheric pressure, corrected to 60 degrees Fahrenheit.

Where a State regulatory agency specifies a definition of crude oil which differs from that set forth above for statistical purposes, the State definition should be followed.

DD\&A: Abbreviation for depreciation, depletion and amortization.

Deferred Taxes: Taxes accrued and reflected as an expense in a company's income statement, but not payable to the taxing authority in that time period. These taxes are accrued to compensate for an understatement of income tax expense which would occur if only the tax currently due to the taxing authority were reflected as the total income tax expense.

Depletion: A term for either (1) a periodic assignment to expense of recorded amounts or (2) an allowable income tax deduction that is related to the exhaustion of mineral reserves. Depletion is included as one of the elements of amortization. When used in that manner, depletion refers only to book depletion (see definition for Amortization).

- Book. The portion of the carrying value (other than the portion associated with tangible assets) prorated in each accounting period, 'for financial reporting purposes, to the extracted portion of an economic interest in a wasting natural resource.

- Tax-cost. A deduction (allowance) under U.S. Federal Income taxation normally calculated under a formula whereby the adjusted basis of the mineral property is multiplied by a fraction, the numerator of which is the number of units of minerals sold during the tax year and the denominator of which is the estimated number of units of unextracted minerals remaining at the end of the tax year plus the number of units of minerals sold during the tax year.

- Tax-percentage (or Statutory). A deduction (allowance) allowed to certain mineral producers under U.S. Federal income taxation calculated on the basis of a specified percentage of gross revenue from the sale of minerals from each mineral property not to exceed the lesser of 50 percent of the taxable income from the property computed without allowance for depletion. (There are also other limits on percentage depletion on oil and gas production.) The taxpayer is entitled to a deduction representing the amount of tax-cost depletion or percentage (statutory) depletion, whichever is higher.

- Excess Statutory Depletion. The excess of estimated statutory depletion allowable as an income tax deduction over the amount of cost depletion otherwise allowable as a tax deduction, determined on a total enterprise basis. 
Depreciation: See definition for Amortization.

Development: The preparation of a specific mineral deposit for commercial production; this preparation includes construction of access to the deposit and of facilities to extract the minerals. The development process is sometimes further distinguished between a preproduction stage and a current stage, with the distinction being made on the basis of whether the development work is performed before or after production from the mineral deposit has commenced on a commercial scale.

Development Costs: Costs incurred to obtain access to proved reserves and to provide facilities for extracting, treating, gathering, and storing the oil and gas. More specifically, development costs, and also depreciation and applicable operating costs of support equipment and facilities and other costs of development activities, are costs incurred to:

- Gain access to and prepare well locations for drilling, including surveying well locations for the purpose of determining specific development drilling sites, clearing ground, draining, road building, and relocating public roads, gas lines, and power lines, to the extent necessary in developing the proved reserves;

- Drill and equip development wells, developmenttype stratigraphic test wells, and service wells, including the costs of platforms and of well equipment such as casing, tubing, pumping equipment, and the wellhead assembly;

- Acquire, construct, and install production facilities such as lease flow lines, separators, treaters, heaters, manifolds, measuring devices, and production storage tanks, natural gas cycling and processing plants, and utility waste disposal systems; and

- Provide improved recovery systems.

Distillate: A general classification for one of the petroleum fractions produced in conventional distillation operations. Included are kerosene and products known as heating oils and diesel fuels, specifically: No. 1, No. 2, and No. 4 Fuel Oils and No. 1, No. 2, and No. 4 Diesel Fuels.

Domestic Operations: Domestic operations are those operations located in the United States.

- The United States is defined as the 50 States, including their offshore territorial waters, the
District of Columbia, U.S. commonwealth territories, and protectorates.

Drilling: The act of boring a hole (1) to determine whether minerals are present in commercially recoverable quantities and (2) to accomplish production of the minerals (including drilling to inject fluids).

- Exploratory. Drilling to locate probable mineral deposits or to establish the nature of geological structures; such wells may not be capable of production if minerals are discovered.

- Developmental. Drilling to delineate the boundaries of a known mineral deposit to enhance the productive capacity of the producing mineral property.

- Directional. Drilling that is deliberately made to depart significantly from the vertical.

Drilling and Equipping of Wells: The drilling and equipping of wells through completion of the "christmas tree."

Dry-Hole Charge: The charge-off to expense of a previously capitalized cost upon the conclusion of an unsuccessful drilling effort.

Equity in Earnings of Unconsolidated Affiliates: A company's proportional share (based on ownership) of the net earnings or losses of an unconsolidated affiliate.

Exploration: The identification of areas that may warrant examination and to examine specific areas that are considered to have prospects of containing oil and gas reserves, including drilling exploratory wells and exploratory-type stratigraphic test wells. Exploration costs may be incurred both before acquiring the related property (sometimes referred to in part as prospecting costs) and after acquiring the property.

Exploration Costs: Costs, including depreciation and applicable operating costs, of support equipment and facilities and other costs directly identifiable with exploration activities, such as:

- Costs of topographical, geological, and geophysical studies, rights of access to properties to conduct those studies, and salaries and other expenses of geologists, geophysical crews, and others conducting those studies. Collectively, these costs are sometimes referred to as geological and geophysical, or "G\&G" costs. 
- Costs of carrying and retaining undeveloped properties, such as delay rentals, ad valorem taxes on the properties, legal costs for title defense, and the maintenance of land and lease records.

- Dry hole contributions and bottom hole contributions. Costs of drilling and equipping exploratory wells.

- Costs of drilling exploratory-type stratigraphic test wells.

Extraordinary Item: Income and expense items associated with events and transactions that possess a high degree of abnormality and are of a type that would not reasonably be expected to recur in the foreseeable future.

Field: An area consisting of a single reservoir or multiple reservoirs all grouped on or related to the same individual geological structural feature and/or stratigraphic condition. There may be two or more reservoirs in a field which are separated vertically by intervening impervious strata, or laterally by local geologic barriers, or by both.

Footage Drilled: Total footage for wells in various categories, as reported for any specified period, includes (1) the deepest total depth (length of well bores) of all wells drilled from the surface, (2) the total of all bypassed footage drilled in connection with reported wells, and (3) all new footage drilled for directional "sidetrack" wells. Footage reported for directional "sidetrack" wells does not include footage in the common bore which is reported as footage for the original well. In the case of old wells drilled deeper, the reported footage is that which was drilled below the total depth of the old well.

- Deepest Total Depth. The deepest total depth of a given well is the distance from a surface reference point (usually the Kelly bushing) to the point of deepest penetration measured along the well bore. If a well is drilled from a platform or barge over water, the depth of the water is included in the total length of the well bore.

- Sidetrack Drilling. This is a remedial operation that results in the creation of a new section of well bore for the purpose of (1) detouring around junk, (2) redrilling lost hole, or (3) straightening key seats and crooked holes. Directional "sidetrack" wells do not include footage in the common bore which is reported as footage for the original well.
Foreign Access: Refers to proved reserves of crude (including lease condensate) and natural gas liquids applicable to long-term supply agreements with foreign governments or authorities in which the company acts as producer.

Foreign Operations: These are operations that are located outside the United States. Determination of whether an enterprise's mobile assets, such as offshore drilling rigs or ocean-going vessels, constitute foreign operations should depend on whether such assets are normally identified with operations located outside the United States.

Foreign operations are segregated into the following areas for FRS reporting purposes:

- OECD Europe. Includes Austria, Belgium, Denmark, Finland, France, the Federal Republic of Germany, Greece, Iceland, Ireland, Italy, Luxembourg, the Netherlands, Norway, Portugal, Spain, Sweden, Switzerland, Turkey, and the United Kingdom.

- Former Soviet Union (FSU) and East Europe. The Baltic States of Estonia, Latvia, and Lithuania, as well as Armenia, Azerbaijan, Belarus, Georgia, Kazakhstan, Kyrgystan, Moldova, Russia, Tajikstan, Turkmenistan, Ukraine, Uzbekistan, Albania, Bulgaria, Czech Republic, Hungary, Poland, Romania, Slovakia, and Yugoslavia.

- Middle East. Includes Saudi Arabia, the United Arab Emirates, Iraq, Iran, Kuwait, the Iraq-Saudi Arabia Neutral Zone, Qatar, Dubai, Bahrain, Oman, Yemen, Syria, Jordan, and Israel.

- Canada.

- Africa (the African continent).

- Other Eastern Hemisphere. Areas eastward of the Greenwich prime meridian to 180 degrees longitude and not included.in other specified domestic or foreign classifications.

- Other Western Hemisphere. Areas westward of the Greenwich prime meridian to 180 degrees longitude not included in other domestic or foreign classifications.

Funds From Operations: Calculated by adding noncash charges back to net income or contribution to net income. Deferred taxes and depreciation, depletion, and amortization (DD\&A) are the largest noncash charges. 
Funds, Total Sources of: The total source of funds including net income plus noncash charges such as DD\&A and deferred taxes, issuances of stocks and bonds, and proceeds from the sale or property, plant, and equipment. The concept is similar to cash flow generated, but does not attempt to account for changes in working capital items. Thus, for example, an inventory buildup or drawdown would not be accounted for under the "funds" concept since both cash and inventory are items of working capital.

Geological and Geophysical (G\&G) Costs: Costs incurred in making geological and geophysical studies, including, but not limited to, costs incurred for salaries, equipment, obtaining rights of access, and supplies for scouts, geologists, and geophysical crews.

Hydrocarbon: An organic chemical compound of hydrogen and carbon in either the gaseous, liquid, or solid phase. The molecular structure of hydrocarbon compounds varies from the simplest (e.g., methane, a constituent of natural gas) to the very heavy and very complex.

Improved Recovery: The operation whereby crude oil or natural gas is recovered using any method other than those that rely primarily on the use of natural reservoir pressure, gas lift, or a pump.

Intangible Drilling and Development Costs (IDC): Costs incurred in preparing well locations, drilling and deepening wells, and preparing wells for initial production up through the point of installing control valves. None of these functions, because of their nature, have salvage value. Such costs would include labor, transportation, consumable supplies, drilling tool rentals, site clearance, and similar costs.

Investment and Advances to Unconsolidated Affiliates: The balance sheet account representing the cost of investments and advances to unconsolidated affiliates. Generally, affiliates which are less. than 50 percent owned by a company may not be consolidated into the company's financial statements.

Lease Bonus: An amount paid by a lessee to a lessor as consideration for granting a lease, usually as a lump sum; this payment is in addition to any rental or royalty payments.

Lease Equipment: All equipment located on the leaseexcept the well and the complete christmas tree installation.
Lifting Costs: The costs associated with the extraction of a mineral reserve from a producing property. (See definition for Production Cost.)

Mineral: Any of the various naturally occurring substances (such as coal, crude oil, metals, natural gas, salt, sand, stone, sulfur, and water) usually obtained from the earth. The term is used to include all wasting, i.e., nonregenerative, inorganic substances that are extracted from the earth.

Mineral Interests in Properties (hereinafter referred to as Properties): These include fee ownership or a lease, concession, or other contractual interest representing the right to extract minerals subject to such terms as may be imposed by the conveyance of those interests. Properties also include royalty interests, production payments payable in oil or gas, and other nonoperating interests in properties operated by others. Properties include those agreements with foreign governments or authorities under which an enterprise participates in the operation of the related properties or otherwise serves as "producer" of the underlying reserves, but properties do not include other supply agreements or contracts that represent the right to purchase (as opposed to extract) oil and gas.

Mineral Lease: An agreement wherein a mineral interest owner (lessor) conveys to another party (lessee) the rights to explore for, develop, and produce specified minerals. The lessee acquires a working interest and the lessor retains a nonoperating interest in the property, referred to as the royalty interest, each in proportions agreed upon.

Mineral Rights: The ownership of the minerals beneath the earth's surface with the right to remove them. Mineral rights may be conveyed separately from surface rights.

Mining: Any activity directed to the extraction of ore and associated rock. Included are open pit work, quarrying, augering, alluvial dredging, and combined operations, including surface and underground operations.

Minority Interest in Income: The proportional share of the minority ownership's interest (less than 50 percent) in the earnings or losses of the consolidated subsidiary.

Subsidiaries are generally fully consolidated when a share of ownership between 51 percent and 100 percent is held by the parent. In consolidation, 100 percent of revenues, expenses, assets, etc. are included in the financial statements even though, for example, the 
subsidiary is only 80 percent owned by the parent company. In such cases, the consolidated balance sheet must have a caption on the right-hand side titled something like "minority interests in consolidated affiliates," and the income statement must have a similar line to reduce net income to the pro rata $(80$ percent in this example) share of the consolidated subsidiary's net income.

Motor Gasoline (Finished): A complex mixture of relatively volatile hydrocarbons, with or without small quantities of additives, that has been blended to form a fuel suitable for use in spark-ignition engines. Motor gasoline, as given in ASTM Specification D439 or Federal Specification VV-G-1690B, includes a range in distillation temperatures from 122 to 158 degrees Fahrenheit at the 10-percent recovery point and from 365 to 374 degrees Fahrenheit at the 90-percent recovery point. Motor gasoline includes reformulated motor. gasoline, oxygenated motor gasoline, and other finished motor gasoline. Blendstock is excluded until blending has been completed.

- Reformulated Motor Gasoline. Gasoline reformulated for use in motor vehicles, the composition and properties of which meet the requirements of the reformulated gasoline regulations promulgated by the U.S. Environmental. Protection Agency under Section 211K of the Clean Air Act.

- Oxygenated Gasoline. Gasoline formulated for use in motor vehicles that has an oxygen content of $1: 8$ percent or higher, by weight. Includes gasohol:

- Other Finished Gasoline. Motor Gasoline not included in the oxygenated or reformulated gasoline categories.

Motor Gasoline, Finished Gasohol: A blend of finished motor gasoline (leaded or unleaded) and alcohol. (generally ethanol but sometimes methanol), limited to 10 percent by volume of alcohol.

Motor Gasoline, Finished Leaded: Contains more than 0.05 gram of lead per gallon or more than 0.005 gram of phosphorus per gallon. Premium and regular grades are included, depending on the octane rating. Includes leaded gasohol. Blendstock is excluded until blending has been completed. Alcohol that is to be used in the blending of gasoline is excluded.

Motor Gasoline, Finished Unleaded: Contains not more than 0.05 gram of lead per gallon and not more than 0.005 gram of phosphorus per gallons. Premium and regular grades are included, depending on the octane rating. Includes unleaded gasohol. Blendstock is excluded until blending has been completed. Alcohol that is to be used in the blending of gasohol is also excluded.

MTBE (Methyl tertiary butyl ether) (CH3)3C)CH: An ether intended for motor gasoline blending. (See definition for Oxygenates.)

Natural Gas: A mixture of hydrocarbon compounds and small quantities of various nonhydrocarbons existing in the gaseous phase or in solution with crude oil in natural underground reservoirs at reservoir conditions. The principal hydrocarbons usually contained in the mixture are methane, ethane, propane, butanes, and pentanes. Typical nonhydrocarbon bases which may be present in reservoir natural gas are carbon dioxide, helium, hydrogen sulfide, and nitrogen. Under reservoir conditions, natural gas and the liquefiable portions thereof occur either in a single gaseous phase in the reservoir or in solution with crude oil and are not distinguishable at that time as separate substances.

Natural gas, based on the type of occurrence in the reservoir, is classified by two categories, as follows:

- Non-Associated Gas is natural gas that is not in contact with significant quantities of crude oil in the reservoir.

- Associated/Dissolved Gas is the combined volume of natural gas which occurs in crude oil reservoirs either as free gas (associated) or as gas in solution with crude oil (dissolved).

Associated gas is free natural gas, commonly known as gas cap gas, which overlies and is in contact with crude oil in the reservoir. Dissolved gas is natural gas that is in solution with crude oil in the reservoir at reservoir conditions.

Statistical data pertaining to natural gas production and reserves are reported in units of 1,000,000 cubic feet (i.e., MMCF) at 14.73 pounds per square inch absolute and 60 degrees Fahrenheit for FRS purposes.

Natural Gas Liquids (NGL): Natural gas liquids are those portions of reservoir gas which are liquefied at the surface in lease separators, field facilities, or gas processing plants. Natural gas liquids include but are not limited to: ethane, propane, butanes, pentanes, natural gasoline, and condensate. 
Net Investment in Place: The sum of net property, plant, and equipment (PP\&E) plus investment and advances to unconsolidated affiliates.

Nonbranded Product: Any refined petroleum product that is not a branded product.

Nuclear Fuel Operations: All nuclear fuel operations, excluding reactor and reactor component manufacturing or containment construction. Includes exploration and development; mining; milling; conversion; enrichment; fabrication; reprocessing; and spent fuel storage.

Offshore: That geographic area that lies seaward of the coastline. In general, the coastline is the line of ordinary low water along with that portion of the coast that is in direct contact with the open sea or the line marking the seaward limit of inland water.

If a State agency uses a different basis for classifying onshore and offshore areas, the State classification should be used. (Cook Inlet in Alaska is classified as offshore.)

Oil Shale: A sedimentary rock containing kerogen, a solid organic material.

Operating Expenses: Segment expenses related both to revenue from sales to unaffiliated customers and revenue from intersegment sales or transfers, excluding loss on disposition of property, plant, and equipment; interest expenses and financial charges; foreign currency translation effects; minority interest; and income taxes.

Operating Income: Operating revenues less operating expenses. Excludes items of other revenue and expense, such as equity in earnings of unconsolidated affiliates, dividends, interest income and expense, income taxes, extraordinary items, and cumulative effect of accounting changes.

Operating Revenues: Segment revenues both from sales to unaffiliated customers (i.e., revenue from customers outside the enterprise as reported in the company's consolidated income statement) and from intersegment sales or transfers, if any, of product and services similar to those sold to unaffiliated customers, excluding equity in earnings of unconsolidated affiliates; dividend and interest income; gain on disposition of property, plant, and equipment; and foreign currency translation effects.

Other Energy Operations: Energy operations not included in Petroleum or Coal. Other Energy includes nuclear, oil shale, tar sands, coal liquefaction and gasification, geothermal, solar, and other forms of nonconventional energy.

Oxygenates: Any substance which, when added to gasoline, increases the amount of oxygen in that gasoline blend. Through a series of waivers and interpretive rules, the Environment Protection Agency (EPA) has determined the allowable limits for oxygenates in unleaded gasoline. The "Substantially Similar" Interpretive Rules (56 FR (February 11, 1991)) allows blends of aliphatic alcohols other than methanol and aliphatic ethers, provided the oxygen content does not exceed 2.7 percent by weight. The "Substantially Similar" Interpretive Rules also provide for blends of methanol up to 0.3 percent by volume exclusive of other oxygenates, and butanol or alcohols of a higher molecular weight up to 2.75 percent by weight. Individual waiver pertaining to the use of oxygenates in unleaded gasoline have been issued by the EPA. They include:

- Fuel Ethanol. Blends of up to 10 percent by volume anhydrous ethanol (200 proof) (commonly referred to as the "gasohol waiver").

- Methanol. Blends of methanol and gasoline-grade tertiary butyl alcohol (GTBA) such that the total oxygen content does not exceed 3.5 percent by weight and the ratio of methanol to GTBA is less than or equal to 1 . It is also specified that this blended fuel must meet American Society for Testing and Materials (ASTM) volatility specifications (commonly referred to as the "ARCO" waiver).

Blends of up to 5.0 percent by volume methanol with a minimum of 3.5 percent by volume cosolvent alcohols having a carbon number of 4 or less (i.e., ethanol, propanol, butanol, and/or GTBA). The total oxygen must not exceed 3.7 percent by weight, and the blend must meet ASTM volatility specifications as well as phase separation and purity specifications (commonly referred to as the "DuPont" waiver).

- MTBE (Methyl tertiary butyl ether). Blends up to 15.0 percent by volume MTBE which must meet the ASTM D4814 specifications. Blenders must take precautions that the blends are not used as base gasolines for other oxygenated blends (commonly referred to as the "Sun" waiver).

PP\&E, Additions to: The current year's expenditures on property, plant, and equipment (PP\&E). The amount is predicated upon each reporting company's accounting practice. That is, accounting practices with regard to 
capitalization of certain items may differ across.companies, and therefore this figure in FRS will be a function of each reporting company's policy.

PP\&E, Net: The original cost of property, plant, and equipment (PP\&E), less accumulated depreciation.

Petroleum: Hydrocarbon mixtures broadly defined to include crude oil, lease condensate, natural gas, products of natural gas processing plants (plant products), refined products, and semifinished products and blending materials.

Pipelines, Rate Regulated: FRS establishes three pipeline segments: crude/liquid (raw materials); natural gas; and refined products. The pipelines included in these segments are all Federally or State rate-regulated pipeline operations, which are included in the reporting company's consolidated financial statements. However, at the reporting company's option, intrastate pipeline operations may be included in the U.S. Refining/ Marketing Segment if: they would comprise less than 5 percent of U.S. Refining/Marketing Segment net PP\&E, revenues, and earnings in the aggregate; and if the inclusion of such pipelines in the consolidated financial statements adds less than $\$ 100$ million to the net PP\&E reported for the U.S. Refining/Market Segment.

Primary Recovery: The crude oil or natural gas recovered by any method that may be employed to produce them where the fluid enters the well bore by the action of natural reservoir pressure (energy or gravity).

Primary Transportation: Conveyance of large shipments of petroleum raw materials and refined products usually by pipeline, barge, or ocean-going vessel. All crude oil transportation is primary, including the small amounts moved by truck. All refined product transportation by pipeline, barge, or ocean-going vessel is primary transportation.

Producing Property: A term often used in reference to a property, well, or mine that produces wasting natural resources. The term means a property that produces in paying quantities (that is, one for which proceeds from production exceed operating expenses).

Production, Natural Gas Liquids: Production of natural gas liquids is classified as follows:

- Contract Production. Natural gas liquids accruing to a company because of its ownership of liquids extraction facilities that it uses to extract liquids from gas belonging to others, thereby earning a portion of the resultant liquids.

- Leasehold Production. Natural gas liquids produced, extracted, and credited to a company's interest.

- Contract Reserves. Natural gas liquid reserves corresponding to the contract production defined above.

- Leasehold Reserves. Natural gas liquid reserves corresponding to the leasehold production defined above.

Production, Oil and Gas: The lifting of the oil and gas to the surface and gathering, treating, field processing (as in the case of processing gas to extract liquid hydrocarbons), and field storage. The production function shall normally be regarded as terminating at the outlet valve on the lease or field production storage tank; if unusual physical or operational circumstances exist, it may be more appropriate to regard the production function as terminating at the first point at which oil, gas, or gas liquids are delivered to a main pipeline, a common carrier, a refinery, or a marine terminal.

- Gross Company-Operated Production. Total production from all company-operated properties, including all working and nonworking interests.

- Net Working Interest Production. Total production accruing to the reporting company's working interests less royalty oil and volumes due others.

Production Costs: Costs incurred to operate and maintain wells and related equipment and facilities, including depreciation and applicable operating costs of support equipment and facilities and other costs of operating and maintaining those wells and related equipment and facilities. They become part of the cost of oil and gas produced. The following are examples of production costs (sometimes called lifting costs):

- Costs of labor to operate the wells and related equipment and facilities.

- Repair and maintenancé costs.

- The costs of materials, supplies, and fuel consumed and services utilized in operating the wells and related equipment and facilities. 
- The costs of property taxes and insurance applicable to proved properties and wells and related equipment and facilities.

- The costs of severance taxes.

Depreciation, depletion, and amortization (DD\&A) of capitalized acquisition, exploration, and development costs are not production costs but also become part of the cost of oil and gas produced along with production (lifting) costs identified above.

Production costs include the following subcategories of costs:

- Well operations and maintenance

- Well workovers

- Operating fluid injection and improved recovery programs

- Operating gas processing plants

- Ad valorem taxes

- Production or severance taxes

- Other, including overhead.

Research and Development: Basic and applied research in the sciences and engineering and the design and development of prototypes and processes, excluding quality control, routine product testing, market research, sales promotion, sales service, research in the social sciences or psychology, and other non-technological activities or technical services.

Reserves, Change in: For FRS reporting, the following definitions should be used for changes in reserves.

- Revisions of Previous Estimates. Changes in previous estimates of proved reserves, either upward or downward, resulting from new information normally obtained from development drilling and production history or resulting from a change in economic factors. Revisions do not include changes in reserve estimates resulting from increases in proved acreage or from improved recovery techniques.

- Improved Recovery. Changes in reserve estimates resulting from application of improved recovery techniques shall be separately shown, if significant.
If not significant, such changes shall be included in revisions of previous estimates.

- Purchases or Sales of Minerals-in-Place. Increase or decrease in the estimated quantity of reserves resulting from the purchase or sale of mineral rights in land with known proved reserves.

- Extensions, Discoveries, and Other Additions. Additions to an enterprise's proved reserves that result from (1) extension of the proved acreage of previously discovered (old) reservoirs through additional drilling in periods subsequent to discovery and (2) discovery of new fields with proved reserves or of new reservoirs of proved reserves in old fields.

Reserves (Coal): Coal reserve estimates comprising the demonstrated coal reserve base include only proved (measured) and probable (indicated).

- Proved (Measured) Reserves. Reserves or resources for which tonnage is computed from dimensions revealed in outcrops, trenches, workings, and drill holes and for which the grade is computed from the results of detailed sampling. The sites for inspection, sampling, and measurement are spaced so closely and the geologic character is so well defined that size, shape, and mineral content are well established. The computed tonnage and grade are judged to be accurate within limits which are stated, and no such limit is judged to be different from the computed tonnage or grade by more than 20 percent.

- Probable (Indicated) Reserves. Reserves or resources for which tonnage and grade are computed partly from specific measurements, samples, or production data and partly from projection for a reasonable distance on geologic evidence. The sites available are too widely or otherwise inappropriately spaced to permit the mineral bodies to be outlined completely or the grade established throughout.

Reserves, Net: Includes all proved reserves associated with the company's net working interests. (See definition for Working Interest.)

Reserves, Proved (Oil and Gas): The estimated quantities of crude oil, natural gas, and natural gas liquids which geological and engineering data demonstrate with reasonable certainty to be recoverable in future years from known reservoirs under existing economic and operating conditions. 
Reservoirs are considered proved if economic producibility is supported by one or more of: actual production; conclusive formation test; core analysis; and/or electric or other $\log$ interpretations. The area of a reservoir considered proved includes (1) that portion delineated by drilling and defined by gas-oil and/or oil-water contacts, if any; and (2) the immediately adjoining portions not yet drilled, but which can be reasonably judged as economically productive on the basis of available geological and engineering data. In the absence of information on fluid contacts, the lowest known structural occurrence of hydrocarbons controls the lower proved limited of the reservoir.

Volumes of oil and gas placed in underground storage are not to be considered proved reserves, but should be classified as inventory.

Reserves that can be produced economically through application of improved recovery techniques (such as fluid injection) are included in the "proved" classification when successful testing by a pilot project, or the operation of an installed program in the reservoir, provides support for the engineering analysis on which the project or program was based.

Estimates of proved reserves do not include the following: (1) oil that may become available from known reservoirs but is classified separately as "indicated additional reserves;" (2) crude oil, natural gas, and natural gas liquids, the recovery of which is subject to reasonable doubt because of uncertainty as to geology, reservoir characteristics, or economic factors; (3) crude oil, natural gas, and natural gas liquids that may occur in undrilled prospects; and (4) crude oil, natural gas, and natural gas liquids that may be recovered from oil shales, coal, gilsonite and other such sources.

It is not necessary that production, gathering, or transportation facilities be installed or operative for a reservoir to be considered proved.

For natural gas, an appropriate reduction in the reservoir gas volume is made to cover the removal of the liquefiable portions of the gas and the exclusion of nonhydrocarbon gases where they occur in sufficient quantity to render the gas unmarketable. If the liquefiable portions of the gas are not separately estimated, they need not be separately stated for FRS reporting purposes.

Reservoir: A porous and permeable underground formation containing an individual and separate accumulation of producible hydrocarbons (oil and/or gas) that is confined by impermeable rock.or water barriers and is characterized by a single natural pressure system.

Residual Fuel Oil: The heavier oils that remain after the distillate fuel oils and lighter hydrocarbons are distilled away in refinery operations and that conform to ASTM Specifications D396 and 975. Included are No. 5 , a residual fuel oil of medium viscosity; Navy Special, for use in steam-powered vessels in government service and in shore power plants; No. 6, which includes Bunker $C$ fuel oil, and is used for commercial and industrial heating, electricity generation, and to power ships.

Royalty: A contractual arrangement providing a mineral interest that gives the owner a right to a fractional share of production or proceeds therefrom, that does not contain rights and obligations of operating a mineral property, and that is normally free and clear of exploration, developmental, and operating costs, except production taxes.

Short Ton: A unit of weight that equals 2,000 pounds.

Support Equipment and Facilities: These include, but are not limited to, seismic equipment, drilling equipment, construction and grading equipment, vehicles, repair shops, warehouses, supply points, camps, and division, district, or field offices.

Tangible Development Costs: Cost incurred during the development stage for, access, mineral-handling, and support facilities having a physical nature. In mining, such costs would include tracks, lighting equipment, ventilation equipment, other equipment installed in the mine to facilitate the extraction of minerals, and supporting facilities for housing and care of work forces. In the oil and gas industry, tangible development costs would include well equipment (such as casing, tubing, pumping equipment, and well heads), as well as field storage tanks and gathering systems.

Tar Sands: Naturally occurring bitumen-impregnated sands that yield mixtures of liquid hydrocarbon and that require further processing other than mechanical blending before becoming finished petroleum products.

Timing Differences: Differences between the periods in which transactions affect taxable income and the periods in which they enter into the determination of pretax accounting income. Timing differences originate in one period and reverse or "turn around" in one or more subsequent periods. Some timing differences reduce income taxes that would otherwise be payable 
currently; others increase income taxes that would otherwise be payable currently.

Transfer Price: The monetary value assigned to products, services, or rights conveyed or exchanged between related parties, including those occurring between units of a consolidated entity.

Uncompleted Wells, Equipment, and Facilities Costs: The costs incurred to (1) drill and equip wells that are not yet completed, and (2) acquire or construct equipment and facilities that are not yet completed and installed.

Undeveloped Property: Refers to a mineral property on which development wells or mines have not been drilled or completed to a point that would permit the production of commercial quantities of mineral reserves.

Uranium Oxide: A yellow or brown powder produced from naturally occurring uranium minerals as a result of milling uranium ore or processing uranium-bearing solutions. Synonymous with "yellowcake," $\mathrm{U}_{3} \mathrm{O}_{8}$, or uranium concentrate.

Well: A hole drilled in the earth for the purpose of (1) finding or producing crude oil or natural gas; or (2) providing services related to the production of crude oil or natural gas.

Wells are classified as (1) oil wells; (2) gas wells; (3) dry holes; (4) stratigraphic test wells; or (5) service wells. The latter two types of wells are not counted for FRS reporting.

Oil wells, gas wells, and dry holes are classified as exploratory wells or development wells. Exploratory wells are subclassified as (1) new-pool wildcats; (2) deeper-pool tests; (3) shallow-pool test; and (4) outpost (extension) tests. Well classifications reflect the status of wells after drilling has been completed.

- Completion. The term refers to the installation of permanent equipment for the production of oil or gas.
- Development Well. A well drilled within the proved area of an oil or gas reservoir to the depth of a stratigraphic horizon known to be productive.

- Dry Hole. An exploratory or development well found to be incapable of producing either oil or gas in sufficient quantities to justify completion as an oil or gas well.

- Exploratory Well. A well that is not a development well, a service well, nor a stratigraphic test as those items are defined elsewhere.

- Oil Well. A well completed for the production of crude oil from at least one oil zone or reservoir.

Wellhead Price: The value at the mouth of the well. In general, the wellhead price is considered to be the sales price obtainable from a third party in an arm's length transaction. Posted prices, requested prices, or prices as defined by lease agreements, contracts, or tax regulations should be used where applicable.

Working Interest: An interest in a mineral property that entitles the owner of that interest to all of a share of mineral production from the property, usually subject to a royalty.

A working interest permits the owner to explore, develop, and operate the property. The working interest owner bears the costs of exploration, development, and operation of the property and, in return, is entitled to a share of the mineral production from the property or to a share of the proceeds therefrom. It may be assigned to another party in whole or in part, or it may be divided into other special property interests.

- Gross Working Interest. The reporting company's working interest plus the proportionate share of any basic royalty interest or overriding royalty interest related to the working interest.

- Net Working Interest. The reporting company's working interest not including any basic royalty or overriding royalty interests. 


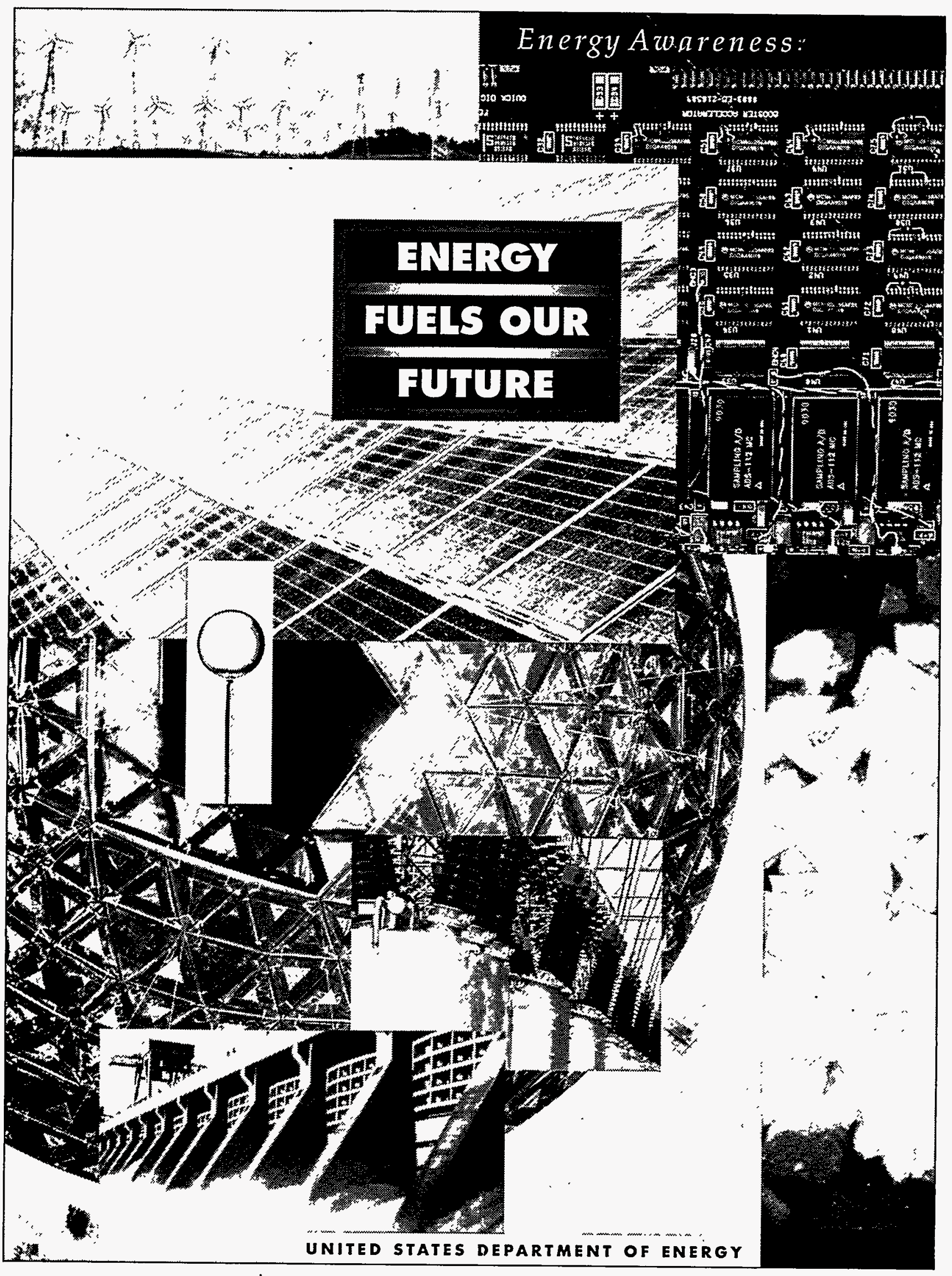




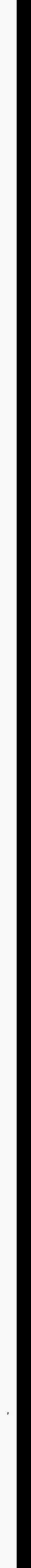




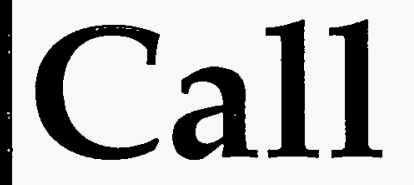

for

your
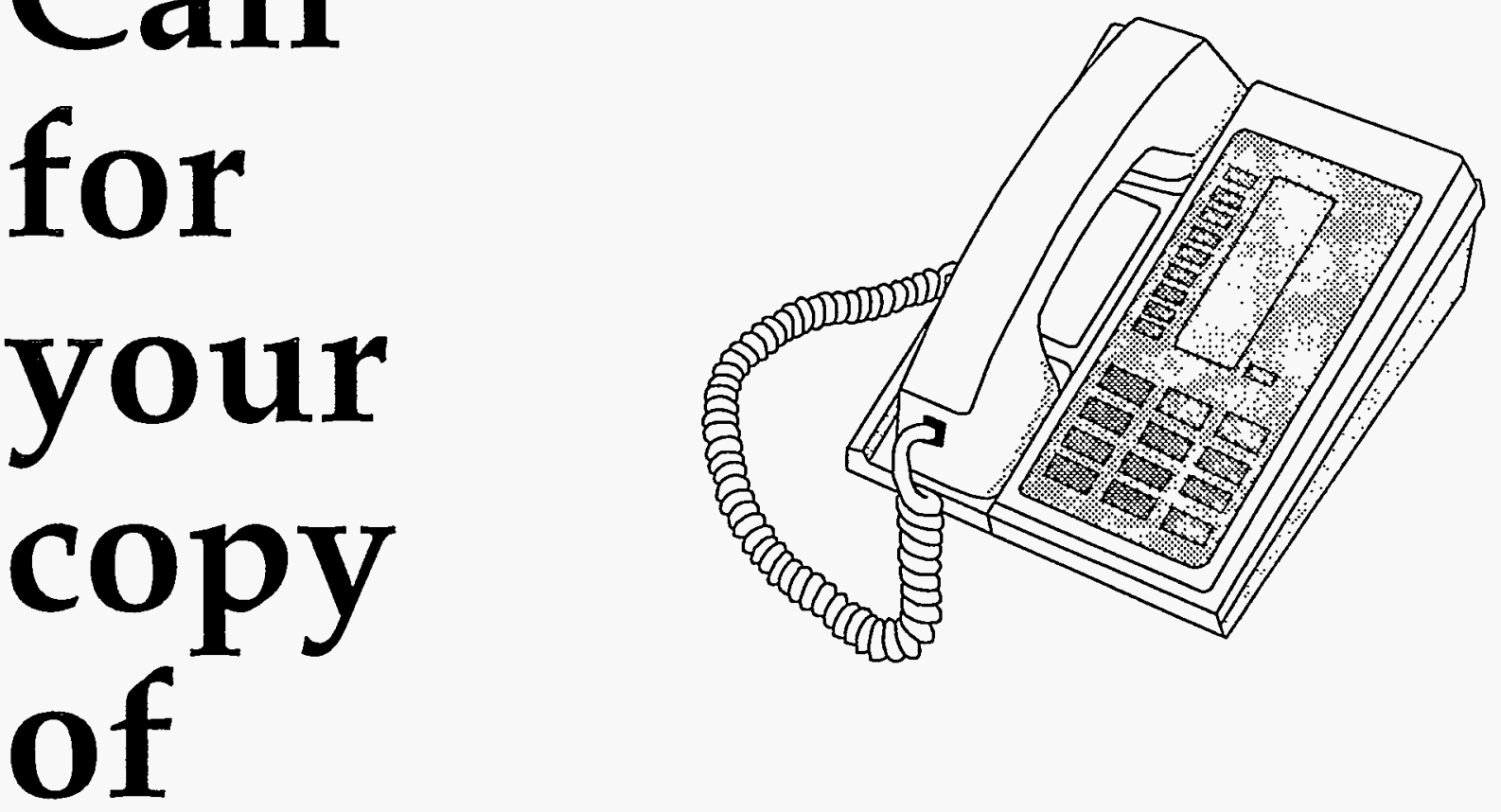

EIA New Releases

A concise and timely review of new statistical publications and energy news

Offered from the National Energy Information Center

For a complimentary copy of this bimonthly bulletin, or a complimentary subscription, call (202)586-8800. 
Energy Information Administration

U.S. Department of Energy

Forrestal Building, El-231

Washington, DC 20585

OFFICIAL BUSINESS

Address Correction Requested

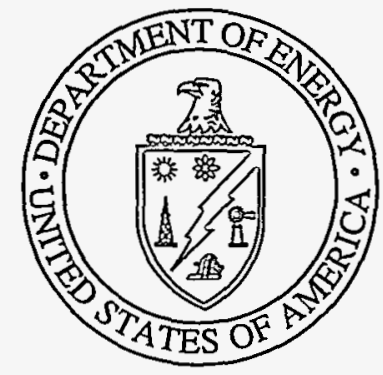

